\title{
MEASURING AND MODELING SUSPENDED SEDIMENT AND NUTRIENT \\ YIELDS IN A MIXED-LAND USE WATERSHED OF THE CENTRAL UNITED STATES
}

A Dissertation
Presented to
the Faculty of the Graduate School
at the University of Missouri
In Partial Fulfillment
of the Requirements for the Degree
Doctor of Philosophy
SEAN J. ZEIGER
Jissertation Advisor: Jason A. Hubbart, Ph.D.
bul


(C) Copyright by Sean J. Zeiger 2016

All Rights Reserved 
The undersigned, appointed by the dean of the Graduate School, have examined the dissertation entitled

\section{MEASURING AND MODELING SUSPENDED SEDIMENT AND NUTRIENT YIELDS IN A MIXED-LAND USE WATERSHED OF THE CENTRAL UNITED STATES}

presented by Sean J. Zeiger,

a candidate for the degree of Ph.D. Natural Resources,

and hereby certify that, in their opinion, it is worthy of acceptance.

Dr. Jason A. Hubbart

Dr. Stephen H. Anderson

Dr. Neil I. Fox

Dr. John M. Kabrick 


\section{ACKNOWLEDGMENTS}

Thanks are due to my advisor, Dr. Jason A. Hubbart, for being an excellent mentor during my graduate program, for reviewing this dissertation and the multiple manuscripts comprised therein, and for his service as chair of my dissertation committee.

I would also like to thank Dr. Stephen H. Anderson, Dr. Neil I. Fox, and Dr. John M. Kabrick for their helpful comments throughout their service on my dissertation committee.

Special thanks are also due to the federal and state agencies that provided funding for this project including the Environmental Protection Agency, Missouri Department of Conservation, and Missouri Department of Natural Resources. This research would not have been possible without their financial support.

Finally, thanks to all of the former and current members of the Interdisciplinary Hydrology Laboratory who contributed their time and effort in the office, lab and field. 


\section{TABLE OF CONTENTS}

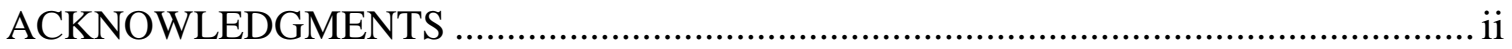

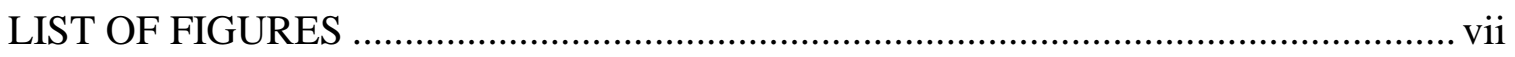

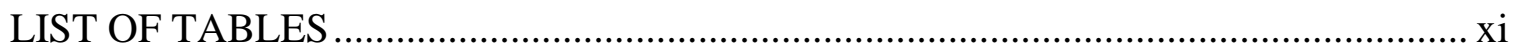

ABSRACT …

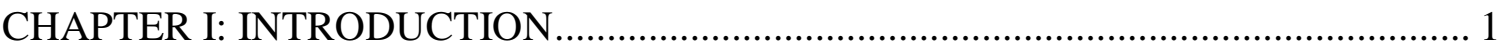

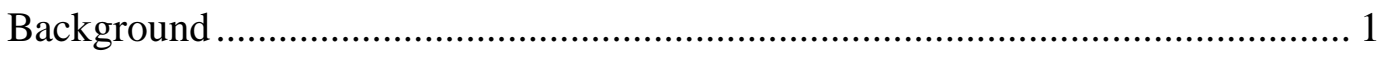

Land-Use and Suspended Sediment Loading.......................................... 2

Land-Use and Nutrient Loading ............................................................ 4

Modeling Suspended Sediment and Nutrient Loading ............................... 5

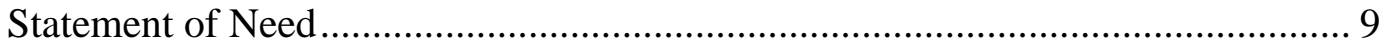

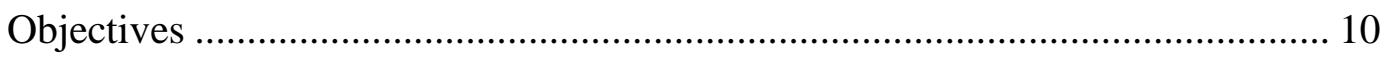

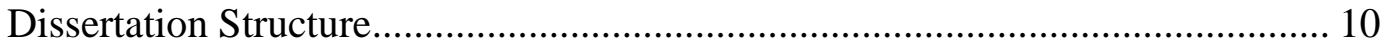

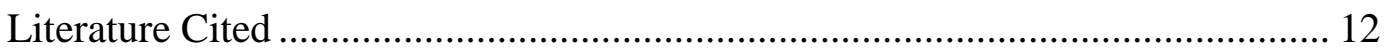

CHAPTER II: QUANTIFYING SUSPENDED SEDIMENT FLUX IN A MIXED-LAND USE URBANIZING WATERSHED USING A NESTED-SCALE STUDY DESIGN .. 18

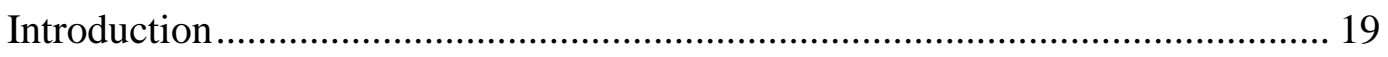

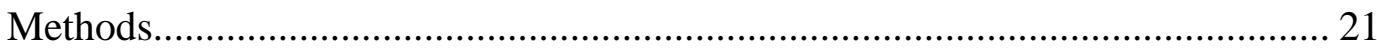

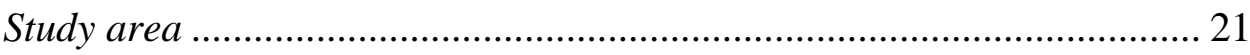

Suspended sediment concentrations ……………………........................ 25

Sediment rating curves and yield .......................................................... 26

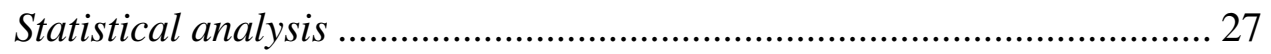

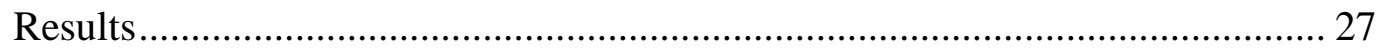


Sediment rating curves and yield .................................................... 32

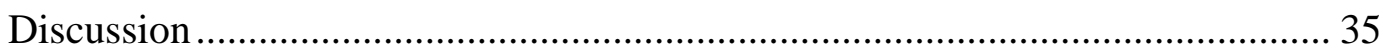

Suspended sediment concentrations .................................................. 35

Sediment rating curves and yield ................................................... 41

Study implications ................................................................... 45

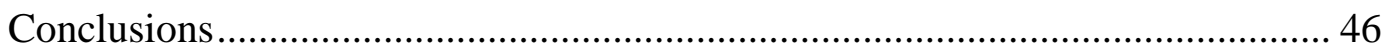

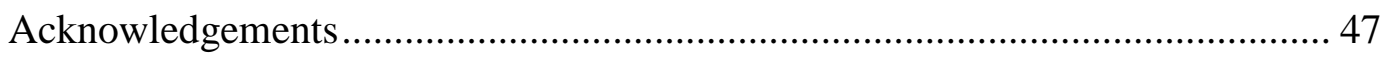

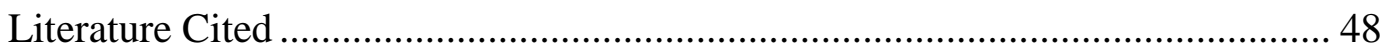

CHAPTER III: NESTED-SCALE NUTRIENT YIELDS FROM A MIXED-LAND USE

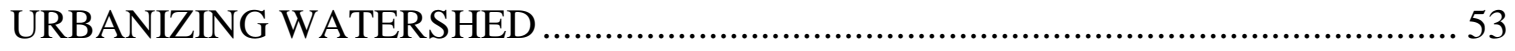

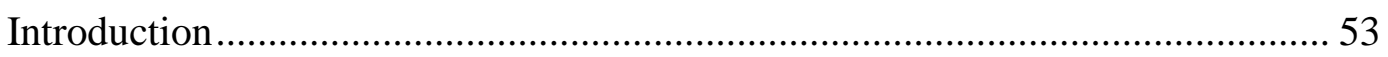

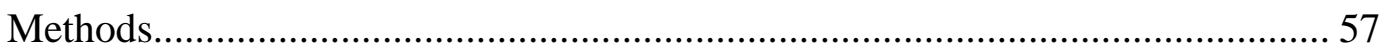

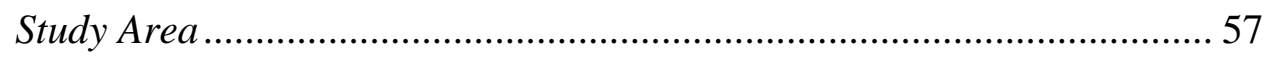

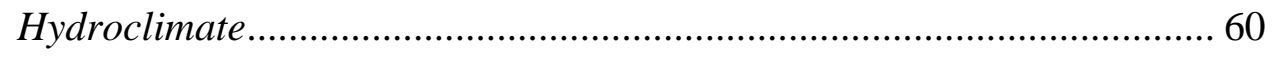

Observed nutrient concentrations................................................... 60

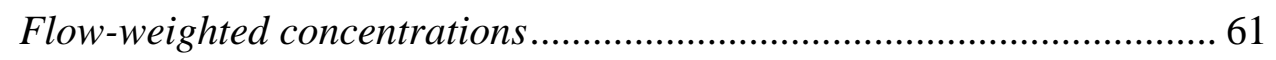

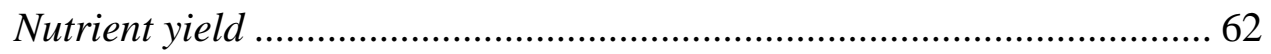

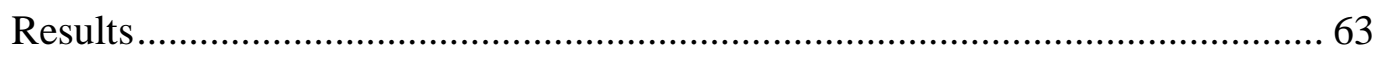

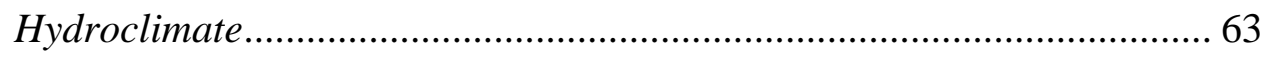

Observed nutrient concentrations ................................................... 65

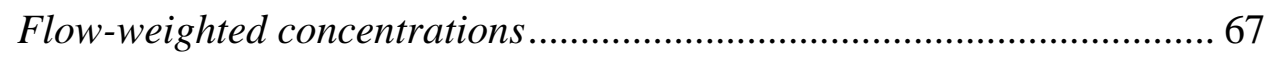

Nutrient yields ........................................................................ 70

Discussion ........................................................................................ 76 


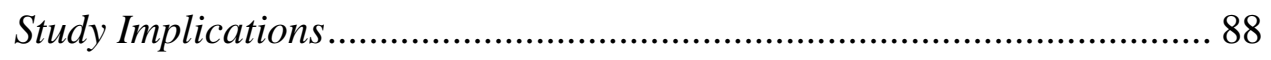

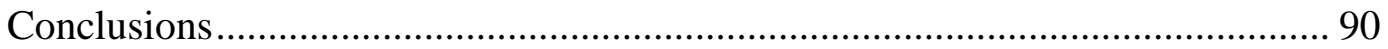

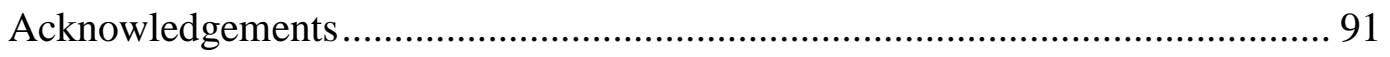

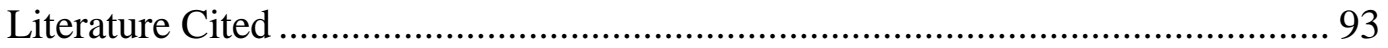

CHAPTER IV: NESTED-SCALE SWAT MODEL ESTIMATIONS OF STREAM FLOW, SEDIMENT AND NUTRIENTS FROM A MIXED-LAND USE WATERSHED

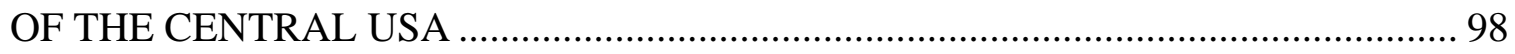

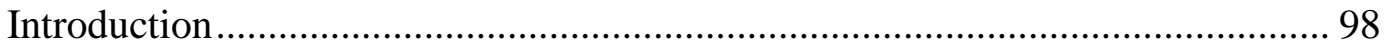

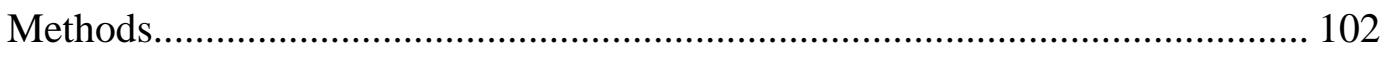

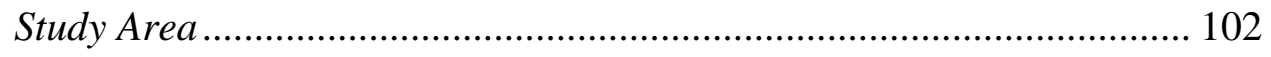

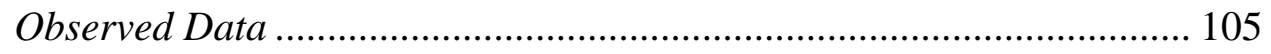

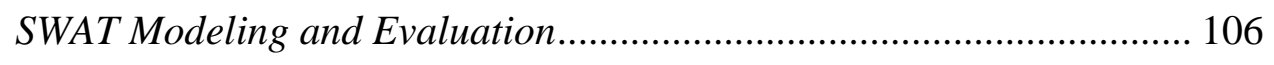

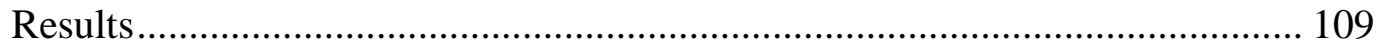

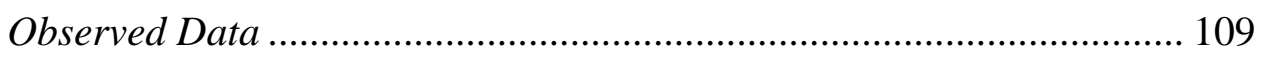

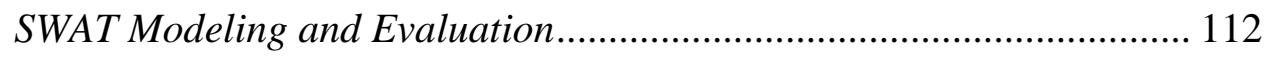

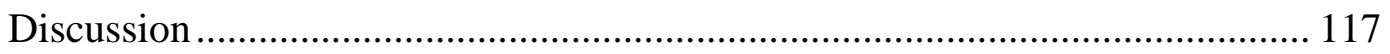

Implications for model development ……………………………......... 129

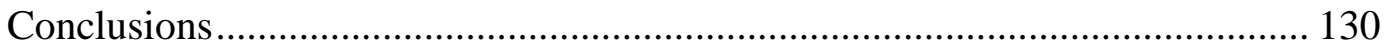

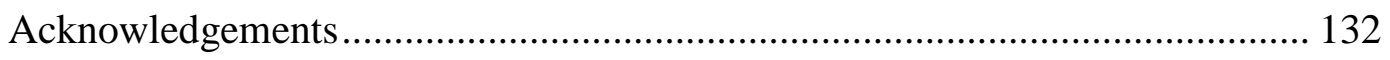

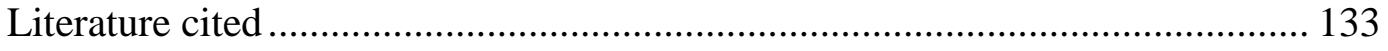

CHAPTER V: CONCLUSIONS AND SYNTHESIS ................................................ 137

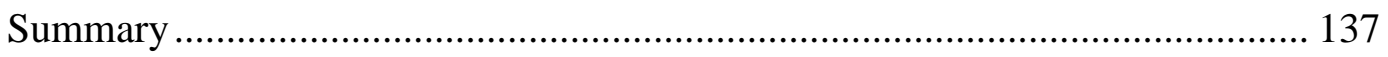

Land-Use and Suspended Sediment Loading....................................... 138

Land-Use and Nutrient Loading ......................................................... 139 
Synthesis of Land Use and Pollutant Loading .......................................... 142

Background ............................................................................ 142

Methods ................................................................................. 145

Results .............................................................................. 148

Discussion ........................................................................... 160

Recommendations for Future Work.................................................... 170

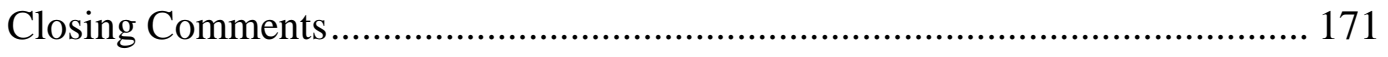

Literature Cited ................................................................................ 173

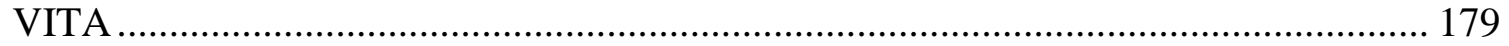




\section{LIST OF FIGURES}

Figure

Page

Figure 2.1. Nested-scale experimental watershed study design including five gauging sites located in Hinkson Creek Watershed, Missouri, USA. 25

Figure 2.2. Suspended sediment (SS) concentration descriptive plots $(n=836)$ from 2010 - 2013 at five gauging sites measured in Hinkson Creek, Missouri, USA. IQR is interquartile range.

Figure 2.3. The change in the cumulative percent agriculture to urban land use with downstream distance from Site \#Site \#1 to \#5 (top). Annual median suspended sediment (SS) concentration ( $n=836$ ) from 2010 - 2013 at five gauging sites (bottom) located in Hinkson Creek, Missouri, USA.

Figure 2.4. Average seasonal and monthly flow weighted mean sediment concentrations (FWC) for each site from 2010 - 2013 measured in Hinkson Creek, Missouri, USA. Error bars show one standard deviation between averages $(n=4)$.

Figure 2.5. Comparisons of results using four methods used to estimate average annual sediment loading $\left(\mathrm{t} \mathrm{yr}^{-1}\right)$ and yields $\left(\mathrm{t} \mathrm{km}^{-2} \mathrm{yr}^{-1}\right)$ in Hinkson Creek Watershed, Missouri, USA. Method 1 is linear interpolation, Method 2 is average sample load, Method 3 is average sample concentration times average sample discharge, and Method 4 is log space discharge-concentration regression. Error bars show one standard deviation between averages $(n=4)$.

Figure 2.6. Annual sediment loads and yields estimated using linear interpolation (Method 1) from 2010 - 2013 at five nested-scale monitoring sites in Hinkson Creek Watershed, Missouri, USA. Study is the four year average. Error bars show the standard deviation of Methods 1 (linear interpolation), 2 (average sample load), 3 (average sample load times average sample discharge), and 4 (log space discharge-concentration regression).

Figure 3.1. Nested-scale experimental watershed study design including five gauging sites located in Hinkson Creek Watershed, Missouri, USA.

Figure 3.2. Log space discharge-load regression relationships $(n=616)$ developed using three years (2010 - 2012) of data collected during the study period (2010 - 2013) from five gauging sites in Hinkson Creek Watershed, Missouri, USA... 
Figure 3.3. Precipitation (left axis-linear) and discharge (right axis-log base 10) data shown for each year from 2010 - 2013 at five gauging sites located in Hinkson Creek Watershed, Missouri, USA.

Figure 3.4. Annual total precipitation (solid line) and nutrient retention for each element from 2010 - 2013 measured in Hinkson Creek, Missouri, USA. Nutrient retention was defined as percent difference in annual flow weighted mean nutrient concentration between Site \#1 in the headwaters and Site \#5 near the watershed outlet. $\mathrm{NH}_{3}-\mathrm{N}$ is total ammonia, $\mathrm{NO}_{2}-\mathrm{N}$ is nitrite, $\mathrm{NO}_{3}-\mathrm{N}$ is nitrate, TIN-N is total inorganic nitrogen, and TP-P is total phosphorus.

Figure 3.5. Monthly average flow weighted mean nutrient concentrations for each site and each element from 2010 - 2013 measured in Hinkson Creek, Missouri, USA. Error bars show one standard deviation between monthly averages $(n=4)$. $\mathrm{NH}_{3}-\mathrm{N}$ is total ammonia, $\mathrm{NO}_{2}-\mathrm{N}$ is nitrite, $\mathrm{NO}_{3}-\mathrm{N}$ is nitrate, $\mathrm{TIN}-\mathrm{N}$ is total inorganic nitrogen, and TP-P is total phosphorus.

Figure 3.6. Nutrient concentration descriptive plots ( $n=858)$ from $2010-2013$ at five gauging sites measured in Hinkson Creek, Missouri, USA. $\mathrm{NH}_{3}-\mathrm{N}$ is total ammonia, $\mathrm{NO}_{2}-\mathrm{N}$ is nitrite, $\mathrm{NO}_{3}-\mathrm{N}$ is nitrate, $\mathrm{TIN}-\mathrm{N}$ is total inorganic nitrogen, TP-P is total phosphorus, and IQR is interquartile range.

Figure 3.7. Time series nutrient concentrations from 2010 - 2013 at five gauging sites measured in Hinkson Creek, Missouri, USA. TIN-N is total inorganic nitrogen, and TP-P is total phosphorus. The red line shows the $0.10 \mathrm{mg} \mathrm{L}^{-1} \mathrm{TP}-\mathrm{P}$ water quality standard for flowing waters that do not discharge directly into lakes or reservoirs.

Figure 4.1. Nested-scale experimental watershed study design including five gauging sites located in Hinkson Creek watershed, Missouri, USA.

Figure 4.2. Observed monthly climate data during the study period (2008-2015) in Hinkson Creek Watershed, USA. Monthly discharge data from Site \#4.

Figure 4.3. Observed monthly discharge (Flow), sediment, total phosphorus (TP), ammonium, nitrite, and nitrate collected during 2010-2013 from five gauging sites in Hinkson Creek Watershed, USA. 
Figure 4.4. Calibrated (hollow symbols) and validated (solid symbols) SWAT model results observed (x-axis) versus simulated (y-axis) daily discharge during the validation period from five gauging sites in Hinkson Creek watershed, USA. Coefficient of determination is $R^{2}$, slope is $m$, and the y-intercept is $y$ of the best fit line between observed vs. simulated daily discharge. 126

Figure 4.5. Uncalibrated (hollow symbols) and calibrated (solid symbols) SWAT model results observed ( $\mathrm{x}$-axis) versus simulated (y-axis) discharge, sediment, total phosphorus (TP), nitrate $\left(\mathrm{NO}_{3}\right)$, and total inorganic nitrogen (TIN) during the calibration period from five gauging sites in Hinkson Creek watershed, USA.. 127

Figure 4.6. Uncalibrated (hollow symbols) and calibrated (solid symbols) SWAT model results observed (x-axis) versus simulated (y-axis) discharge, sediment, total phosphorus (TP), nitrate $\left(\mathrm{NO}_{3}\right)$, and total inorganic nitrogen (TIN) during the validation period from five gauging sites in Hinkson Creek watershed, USA... 128

Figure 5.1. Daily flow duration curves with box and whisker plot for five flow intervals including high flow (0-10\%), moist condition (10-40\%), mid-range flows (40$60 \%$ ), dry condition (60-90\%), and low flow (90-100\%) observed at five gauging sites located in Hinkson Creek watershed, USA. The five sets of box and whisker plots (one set per flow interval) correspond to observed data collected at gauging Sites \#1 to \#5 from left to right. 161

Figure 5.2. Daily suspended sediment load duration curves with box and whisker plot for five flow intervals including high flow (0-10\%), moist condition (10-40\%), midrange flows (40-60\%), dry condition (60-90\%), and low flow (90-100\%) observed at five gauging sites located in Hinkson Creek watershed, USA. The eutrophic threshold was calculated for the downstream most gauging site (Site \#5). The five sets of box and whisker plots (one set per flow interval) correspond to observed data collected at gauging Sites \#1 to \#5 from left to right. 162

Figure 5.3. Daily total ammonium $\left(\mathrm{NH}_{3}-\mathrm{N}\right)$ load duration curves with box and whisker plot for five flow intervals including high flow (0-10\%), moist condition (10$40 \%$ ), mid-range flows (40-60\%), dry condition (60-90\%), and low flow (90$100 \%$ ) observed at five gauging sites located in Hinkson Creek watershed, USA. The eutrophic threshold was calculated for the downstream most gauging site (Site \#5). The five sets of box and whisker plots (one set per flow interval) correspond to observed data collected at gauging Sites \#1 to \#5 from left to right. 
Figure 5.5. Daily nitrate $\left(\mathrm{NO}_{3}-\mathrm{N}\right)$ load duration curves with box and whisker plot for five flow intervals including high flow (0-10\%), moist condition (10-40\%), mid-range flows (40-60\%), dry condition (60-90\%), and low flow (90-100\%) observed at five gauging sites located in Hinkson Creek watershed, USA. The eutrophic threshold was calculated for the downstream most gauging site (Site \#5). The five sets of box and whisker plots (one set per flow interval) correspond to observed data collected at gauging Sites \#1 to \#5 from left to right. 165

Figure 5.6. Daily total inorganic nitrogen (TIN-N) load duration curves with box and whisker plot for five flow intervals including high flow (0-10\%), moist condition (10-40\%), mid-range flows (40-60\%), dry condition (60-90\%), and low flow (90$100 \%$ ) observed at five gauging sites located in Hinkson Creek watershed, USA. The eutrophic threshold was calculated for the downstream most gauging site (Site \#5). The five sets of box and whisker plots (one set per flow interval) correspond to observed data collected at gauging Sites \#1 to \#5 from left to right.

Figure 5.7. Daily total phosphorus (TP-P) load duration curves with box and whisker plot for five flow intervals including high flow (0-10\%), moist condition (10-40\%), mid-range flows (40-60\%), dry condition (60-90\%), and low flow (90-100\%) observed at five gauging sites located in Hinkson Creek watershed, USA. The eutrophic threshold was calculated for the downstream most gauging site (Site \#5). The five sets of box and whisker plots (one set per flow interval) correspond to observed data collected at gauging Sites \#1 to \#5 from left to right 


\section{LIST OF TABLES}

Table

Page

Table 2.1. Cumulative drainage area, land use and land cover area to each gauging site located in Hinkson Creek Watershed (HCW), Missouri, USA.

Table 2.2. Four methods used to calculate sediment yields.

Table 2.3. Summary of statistics for observed sediment (SS) concentrations ( $n=836$ sample days per site) from 2010 - 2013 at five gauging sites measured in Hinkson Creek, Missouri, USA.

Table 2.4. Median monthly, seasonal, and annual $(n=4)$ flow weighted mean sediment concentrations (FWC, mg L ${ }^{-1}$ ) measured at each gauging site in Hinkson Creek, Missouri, USA from 2010 - 2013

Table 2.5. Summary of results ( $p$-values) from Dunn's post-hoc multiple comparison tests for significant differences $(\mathrm{CI}=95 \%)$ between monthly flow weighted mean sediment concentrations (FWC) at each gauging site $(n=5)$ from $2010-2013$ measured in Hinkson Creek, Missouri, USA. Bold font shows significant differences ( $\mathrm{p}$-values less than 0.05). Columns and rows for months where no significant differences were observed are not presented in the table.

Table 2.6. Parameters of log space discharge-concentration regression equations (sediment rating curves) generated using input data (daily average discharge) collected during 2010 - 2013 at five gauging sites in Hinkson Creek Watershed, Missouri, USA.

Table 2.7. Comparisons of results using four methods used to estimate annual sediment loads $\left(\mathrm{t} \mathrm{yr}^{-1}\right)$ and yields $\left(\mathrm{t} \mathrm{km}^{-2} \mathrm{yr}^{-1}\right)$ from Hinkson Creek Watershed $\left(230 \mathrm{~km}^{2}\right.$ drainage area) located in central Missouri, USA. Method 1 is linear interpolation, Method 2 is average sample load, Method 3 is average sample concentration times average sample discharge, and Method 4 is log space dischargeconcentration regression.

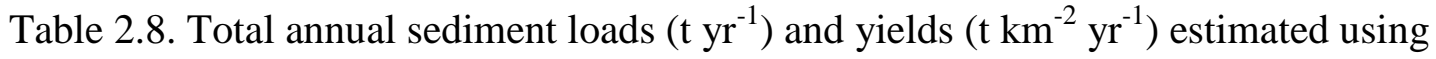
linear interpolation (Method 1) from 2010 - 2013 at five gauging sites in Hinkson Creek Watershed, Missouri, USA. 
Table 3.1. Cumulative stream length $(\mathrm{km})$, drainage area $\left(\mathrm{km}^{2}\right)$, and land use/land cover area $\left(\mathrm{km}^{2}\right)$ to each gauging site located in Hinkson Creek Watershed (HCW), Missouri, USA. Percentages of total drainage area are shown in parentheses. .... 59

Table 3.2. Four methods used to calculate nutrient load estimates. Concentration is $C, Q$ is discharge at the time of sampling, $t$ is time, $K$ is the time interval of load in seconds, $n$ is sample size, $b_{0}$ and $b_{1}$ are fitted regression parameters.

Table 3.3. Summary of average daily climate statistics from $2010-2013$ for five gauging sites located in Hinkson Creek Watershed, Missouri, USA. Precipitation values are annual totals.

Table 3.4. Summary of statistics for observed nutrient concentrations ( $n=858$ sample days per site) from 2010 - 2013 at five gauging sites measured in Hinkson Creek, Missouri, USA.

Table 3.5. Annual $(n=4)$ and seasonal average flow weighted mean nutrient concentrations at each gauging site and each element from 2010 - 2013 measured in Hinkson Creek, Missouri, USA.

Table 3.6. Parameters of log space discharge-load multiple regression equations for annual flow weighted mean nutrient concentrations (nutrient rating curves) as a function of land use generated using input data (daily average discharge) collected during 2010 - 2013 at five gauging sites in Hinkson Creek Watershed, Missouri, USA. 70

Table 3.7. Comparisons of results using four methods used to estimate annual nutrient yields in Hinkson Creek Watershed, Missouri, USA. Method 1 is linear interpolation, Method 2 is average sample load, Method 3 is average sample concentration times average sample discharge, and Method 4 is log space discharge-load regression.

Table 3.8. Total annual nutrient yields estimated using linear interpolation (Method 1) from 2010 - 2013 at five gauging sites in Hinkson Creek Watershed, Missouri, USA.

Table 4.1. Cumulative drainage area, land use and land cover area to each gauging site located in Hinkson Creek Watershed (HCW), Missouri, USA. "HCW" is cumulative of Sites \#1 through \#5. 104 
Table 4.2. Model efficiency ratings used to assess SWAT model performance of stream flow, sediment and nutrients at a monthly time step. Table recreated from Moriasi et al. (2007). 109

Table 4.3. Summary of daily climate statistics generated from SWAT model input data collected during the study period (2008-2015) in Hinkson Creek Watershed, USA. St. Dev. is standard deviation, Air Temp is air temperature, and Rh is relative humidity. 110

Table 4.4. Summary of statistics for observed monthly discharge, sediment, total phosphorus, nitrate, nitrite, and ammonium during the study period collected from five gauging sites in Hinkson Creek Watershed, USA. Total phosphorus is TP.112

Table 4.5. Monthly SWAT model evaluation statistics from five gauging sites in Hinkson Creek watershed, USA. Uncalibrated model evaluation statistics are shown in parenthesis. NSE is Nash-Sutcliffe model efficiency coefficient, PBIAS is percent bias, RSR is the ratio of the root mean square error to the standard deviation of the observed data, Q is discharge, SS is suspended sediment, TP is total phosphorus, and TIN is total inorganic nitrogen.

Table 5.1. Estimated eutrophic and mesotrophic threshold concentrations for total ammonium $\left(\mathrm{NH}_{3}-\mathrm{N}\right)$, nitrite $\left(\mathrm{NO}_{2}-\mathrm{N}\right)$, nitrate $\left(\mathrm{NO}_{3}-\mathrm{N}\right)$, total inorganic nitrogen (TIN-N), total nitrogen (TN-N), total phosphorus (TP-P), suspended sediment (SS) for Hinkson Creek, USA.

Table 5.2. Summary of statistics from flow duration curves showing stream flow in cubic meters per second $\left(\mathrm{m}^{3} \mathrm{~s}^{-1}\right)$ for five flow intervals including high flow (0-10\%), moist condition (10-40\%), mid-range flows (40-60\%), dry condition (60-90\%), and low flow (90-100\%) observed at five gauging sites located in Hinkson Creek watershed, USA.

Table 5.3. Summary of statistics from suspended sediment load duration curves showing loads in metric tons per day $\left(\mathrm{t} \mathrm{day}^{-1}\right)$ for five flow intervals including high flow (0-10\%), moist condition (10-40\%), mid-range flows (40-60\%), dry condition (60-90\%), and low flow (90-100\%) observed at five gauging sites located in Hinkson Creek watershed, USA. 
Table 5.4. Summary of statistics from total ammonium $\left(\mathrm{NH}_{3}-\mathrm{N}\right)$ load duration curves showing loads in kilograms per day $\left(\mathrm{kg} \mathrm{day}^{-1}\right)$ for five flow intervals including high flow (0-10\%), moist condition (10-40\%), mid-range flows (40-60\%), dry condition (60-90\%), and low flow (90-100\%) observed at five gauging sites located in Hinkson Creek watershed, USA.

Table 5.5. Summary of statistics from nitrite $\left(\mathrm{NO}_{2}-\mathrm{N}\right)$ load duration curves showing loads in kilograms per day $\left(\mathrm{kg} \mathrm{day}^{-1}\right)$ for five flow intervals including high flow (0$10 \%$ ), moist condition (10-40\%), mid-range flows (40-60\%), dry condition (6090\%), and low flow (90-100\%) observed at five gauging sites located in Hinkson Creek watershed, USA.

Table 5.6. Summary of statistics from nitrate $\left(\mathrm{NO}_{3}-\mathrm{N}\right)$ load duration curves showing loads in kilograms per day $\left(\mathrm{kg} \mathrm{day}^{-1}\right)$ for five flow intervals including high flow (0-10\%), moist condition (10-40\%), mid-range flows (40-60\%), dry condition (60-90\%), and low flow (90-100\%) observed at five gauging sites located in Hinkson Creek watershed, USA.

Table 5.7. Summary of statistics from total inorganic nitrogen (TIN-N) load duration curves showing loads in kilograms per day $\left(\mathrm{kg} \mathrm{day}^{-1}\right)$ for five flow intervals including high flow (0-10\%), moist condition (10-40\%), mid-range flows (40$60 \%$ ), dry condition (60-90\%), and low flow (90-100\%) observed at five gauging sites located in Hinkson Creek watershed, USA.

Table 5.8. Summary of statistics from total phosphorus (TP-P) load duration curves showing loads in kilograms per day $\left(\mathrm{kg} \mathrm{day}^{-1}\right)$ for five flow intervals including high flow (0-10\%), moist condition (10-40\%), mid-range flows (40-60\%), dry condition (60-90\%), and low flow (90-100\%) observed at five gauging sites located in Hinkson Creek watershed, USA

Table 5.9. Percent of total pollutant loading during multiple flow intervals including high flow (0-10\%), moist condition (10-40\%), mid-range flows (40-60\%), dry condition (60-90\%), and low flow (90-100\%) observed at five gauging sites located in Hinkson Creek watershed, USA. Total ammonium $\left(\mathrm{NH}_{3}-\mathrm{N}\right)$, nitrite $\left(\mathrm{NO}_{2}-\mathrm{N}\right)$, nitrate $\left(\mathrm{NO}_{3}-\mathrm{N}\right)$, total inorganic nitrogen $(\mathrm{TIN}-\mathrm{N})$, total nitrogen (TN$\mathrm{N}$ ), total phosphorus (TP-P), suspended sediment (SS). 
Table 5.10. Stepwise multiple linear regression models for daily flow and pollutant yields at multiple flow intervals including high flow (0-10\%), moist condition (10-40\%), mid-range flows (40-60\%), dry condition (60-90\%), and low flow (90-100\%) observed at five gauging sites located in Hinkson Creek watershed, USA. Total ammonium $\left(\mathrm{NH}_{3}-\mathrm{N}\right)$, nitrite $\left(\mathrm{NO}_{2}-\mathrm{N}\right)$, nitrate $\left(\mathrm{NO}_{3}-\mathrm{N}\right)$, total inorganic nitrogen (TIN-N), total nitrogen (TN-N), total phosphorus (TP-P), suspended sediment (SS), $x_{n}$ is the independent variable, $b$ is the $y$-intercept, $m_{n}$ is the slope, and $R^{2}$ is the coefficient of determination.. 158 


\title{
MEASURING AND MODELING SUSPENDED SEDIMENT AND NUTRIENT YIELDS IN A MIXED-LAND USE WATERSHED OF THE CENTRAL UNITED STATES
}

Sean J. Zeiger

Dissertation Advisor: Jason A. Hubbart, Ph.D.

\begin{abstract}
ABSRACT
Science-based information is needed to better understand mixed-land-use contributions of suspended sediment and nutrient loads to receiving water bodies. Water samples were analyzed for suspended sediments and nutrients using a nested-scale experimental watershed study design ( $n=836$ samples $x 5$ gauging sites) in an urbanizing mixed-land use watershed of the central USA. Highly variable annual precipitation was observed during the four year study period (2010-2013) with the greatest suspended sediment and nutrient yields during 2010 (record setting wet year) and least yields during 2012 (extreme drought year). Estimated annual suspended sediment yields ranged from $16.1 \mathrm{t} \mathrm{km}^{-2} \mathrm{yr}^{-1}$ during 2012 to $313.0 \mathrm{t} \mathrm{km}^{-2} \mathrm{yr}^{-1}$ during 2010. Annual total inorganic nitrogen and total phosphorus yields exceeded 10.3 and $2.04 \mathrm{~kg} \mathrm{ha}^{-1} \mathrm{yr}^{-1}$ from the agricultural dominated headwaters. Multiple linear regression analyses indicated significant $(C I=0.05)$ relationships between pollutant loading, annual total precipitation (positive correlate), urban land use (positive correlate), forested land use (negative correlate), and wetland land use (negative correlate). Results highlight the need for ongoing studies, and improved best management practices designed to reduce suspended sediment and nutrient loading in mixed-land use watersheds globally.
\end{abstract}




\section{CHAPTER I}

\section{INTRODUCTION}

\section{Background}

Inputs of suspended sediment (SS) and nutrients associated with agricultural and urban land uses are among the leading causes of receiving water quality impairment in the USA (Howarth et al., 1996; Carpenter et al., 1998; Clark et al., 1999; Baffaut et al., 2009; Lerch et al., 2015a). While SS is an essential nutrient source for healthy aquatic systems (Dodds and Whiles, 2004; Koirala 2009), excessive SS can reduce primary productivity, decrease invertebrate and fish populations, and smother benthic habitats (Bilotta and Brazier, 2008; Lamba et al., 2015). Additionally, agricultural chemicals adsorbed to SS contribute to problems with water toxicity, eutrophication (i.e. ecosystem response to nutrient enrichment), and hypoxia (i.e. oxygen deficiency) of receiving water bodies (Bilotta and Brazier, 2008). Eutrophication of freshwater ecosystems alone costs an estimated $\$ 2.2$ billion dollars annually in terms of recovery of threatened and endangered species, drinking water, lakefront property values, and losses in recreational use in the USA (Dodds et al., 2008). Additionally, excessive suspended sediment and nutrient yields from inland watersheds are linked to eutrophication associated hypoxic zones that are growing in size and persistence in coastal waters (Rabotyagov et al., 2014). That is why multiple authors stress the need to mitigate water quality problems associated with pollutant loading from inland watersheds to conserve water quality and associated aquatic natural resource commodities (Rabalais et al., 2010; Heimann et al., 2011; Lamba et al., 2014; Rabotyagov et al., 2014). However, the coupled effects of climate variability and land use can cause uncertainties that hinder mitigation efforts (Guo et al., 2014). 
Therefore, science-based information is needed to improve understanding of the interacting impacts of climate and land use on pollutant loading to effectively reduce suspended sediment and nutrient yields from inland watersheds.

\section{Land-Use and Suspended Sediment Loading}

Soil loss in the Mississippi River Basin (MRB) was greatest following land clearing and plowing during European settlement in the 1800's. During this time sediment yields were estimated to be greater than $100 \mathrm{t} \mathrm{km}^{-2} \mathrm{yr}^{-1}$ (Turner and Rabalais, 2003). More recently, Turner and Rabalais (2004) estimated an average sediment yield of $52.3 \mathrm{t} \mathrm{km}^{-2}$ from the MRB to Gulf of Mexico from 1973 to 1994 . Heimann et al., (2011) estimated average SS yield of $40.8 \mathrm{t} \mathrm{km}^{-2}$ from the MRB to Tarbert landing, Mississippi (U.S. Geological Survey gauging Site \#07295100). Heimann et al., (2011) noted that suspended sediment yields have decreased considerably since the 1800 's in part due to installation of many hydropower dams that trap suspended sediments and thereby reduce sediment supply to the Gulf of Mexico. Additionally, soil conservation efforts have helped reduce sediment yields (Walling, 2013).

While soil conservation efforts have helped to conserve terrestrial soil resources (Walling, 2013), water resource problems associated with excessive sediment yields may not be mitigated for decades without corresponding efforts to reduce channel incision and bank erosion (Trimble, 2009). For example, Trimble (2009) showed that conservation practices reduced soil erosion in Coon Creek Basin located in the Upper Mississippi River Basin (UMRB), but sediment yield was unabated mainly due to stream bank erosion processes of legacy sediments in the lower alluvial reaches of the study stream. Trimble (2009) concluded that reduction in sediment yields may be more dependent on 
stream bank stabilization, construction of fish shelter structures and conservation of riparian vegetation. Clearly, there is a need to reduce excessive overland and channel SS loading to improve water quality. However, complex interactions of natural and anthropogenic impacts confound attempts to develop effective management plans. Additional quantitative information is needed to improve understanding of land use practices and sediment yields, especially in urbanizing watersheds where development can alter pollutant transport response to rainfall-runoff events (Walsh et al., 2005).

A major cause of hydrologic alteration in urbanizing watersheds is increased impervious surfaces and engineered waterways that alter sediment transport relative to natural systems (Taylor and Owens, 2009). Chin (2006) noted that land surfaces cleared for urban development, and left for more than one year, can lead to suspended sediment yields of $10,000 \mathrm{t} \mathrm{km}^{-2} \mathrm{yr}^{-1}$ or more. As urban development continues, watershed hydrologic response to rainfall-runoff events can become flashy (i.e. increased peak flows coupled with reduced time to peak flow and time of concentration) which can increase problems with bank wasting, channel incision and scouring (Walsh et al., 2005). Hollister et al., (2008) showed urbanizing mixed-land use watersheds exhibit variable relationships between land use and land cover (LULC) and that SS loading regimes vary depending on the spatial extent considered. For example, deforestation, agricultural and urban land uses are usually cited as sediment generating activities while forests and wetlands are usually sediment sinks (Meybek et al., 2003; Nelson and Booth, 2002; Schottler et al., 2014; Lamba et al., 2015), but that is not always evident in mixed-land use urbanizing watersheds (Nelson and Booth, 2002). There is thus, a need for additional 
investigation of the relationships between climate, land use, and sediment loading in mixed-land use watersheds.

\section{Land-Use and Nutrient Loading}

In the MRB, $\mathrm{N}$ yields as large as $483 \mathrm{~kg} \mathrm{~km}^{-2} \mathrm{yr}^{-1}$, and $\mathrm{P}$ yields as large as $45 \mathrm{~kg}$ $\mathrm{km}^{-2} \mathrm{yr}^{-1}$ have been causally linked to eutrophication of receiving water bodies and the Hypoxic Zone (aka: the Dead Zone) in the Gulf of Mexico (Clark et al., 2000; Battaglin et al., 2001; Rabalais et al., 2002; Turner and Rabalais, 2004; Alexander et al., 2008). Within the MRB, the upper Midwest has been targeted as the critical source area of the greatest nitrogen fertilizer application rates of more than $2.5 \mathrm{t} \mathrm{km}^{-2} \mathrm{yr}^{-1}$ (Mueller and Helsel, 2013) with nine central states, including Missouri, that contribute greater than $75 \%$ of the total $\mathrm{N}$ and P terrestrial loads to the Gulf of Mexico (Alexander et al., 2008). Large-scale environmental problems such as hypoxia in the Gulf of Mexico necessitate focused hydrologic monitoring of critical source areas within the MRB to mitigate anthropogenic impacts to nutrient loading (Hubbart et al., 2010; Birgand et al., 2007). Given that the combined effects of climate and mixed-land uses may confound common assumptions about nutrient loading (particularly $\mathrm{N}$ retention and transport) (Poor and McDonnell et al., 2007; Kaushal et al., 2008), there is a need to quantify relationships between climate, land use, and nutrient loading in mixed-land-use urbanizing watersheds (Kaushal et al., 2008).

Authors of previous studies showed that mixed-land use watersheds (i.e. blended combinations of land use practices) exhibit variously altered watershed hydrology and nutrient inputs relative to wild land or rural counterparts (Bolstad and Swank, 1997; Jordan et al., 1997; Salvia-Castellvi et al., 2005; Poor and McDonnel, 2007). For 
example, Poor and McDonnel (2007) articulated that nitrate concentrations variously mimic storm hydrographs in forested and residential catchments mirroring altered residence times and flow paths consistent with both climate and land use practices. Given non-linear, confounding results to date, many authors have identified decoupling the interactions of hydrology and land use as one of the greatest contemporary land management challenges (Jordan et al., 1997; Salvia-Castellvi et al., 2005; Poor and McDonnel, 2007). For example, Floyd et al., (2009) showed that nitrate concentrations were positively correlated to poorly drained soils $(r=0.63-0.87)$ and negatively correlated to woody vegetation ( $r=-0.81$ to -0.94$)$ at multiple spatial scales of stream buffers $(10,20$, $30,60,90,150,300 \mathrm{~m})$. Correlations were strongest between poorly drained soils and nitrate concentrations at the watershed scale thus indicating the difficulty of disentangling climate and land use effects at the sub-basin scale where best management practices are implemented. Shields et al., (2008) noted that in more developed areas (i.e. impervious area $>15 \%$ ) the majority of nitrogen export occurred during high flow periods, whereas areas with little impervious surfaces (i.e. impervious area $<1 \%$ ) were associated with nitrogen loading during base flow periods. This is an important observation since exported nutrients can cause water quality problems in receiving water bodies (e.g. eutrophication, hypoxia). Locally, excess nutrients that enter stream systems during base flow periods in urban areas are likely to cause eutrophication, particularly during summer months when water temperatures are warmer (Royer et al., 2006). Given predicted future land use changes and climate trends, there is a need to study hydrology and nutrient transport trends in mixed-land use urbanizing watersheds (Kaushal et al., 2008). Modeling Suspended Sediment and Nutrient Loading 
Watershed-scale hydrologic models can be used to provide predictive estimates of the effects of various land management practices on water quantity and quality, often without a large investment of resources (time, labor, and money) from the end user (Borah et al., 2007). However, development of hydrologic models can require substantial investments of resources (Neitsch et al., 2009). Criteria to consider when choosing the appropriate model include, but are not limited to, data input requirements, temporal scale, spatial scale, and desired model output (Arnold et al., 2012). It is also important to understand model limitations. For example, some models are not designed to simulate in mountainous regions with large snowmelt components (Fortaine et al., 2002), or account for the effects of urban land use (Borah et al., 2006).

Physically-based watershed-scale hydrologic and nonpoint-source pollution models can be used to account for the effects of climate and land use on water resources (Borah et al., (2007). While many watershed-scale models are available, it is important to choose the correct model for the application. To assist end-users in model selection, Borah and Bera (2003a) selected for review eleven watershed-scale models including the agricultural nonpoint-source pollution model (AGNPS), annualized AGNPS (AnnAGNPS), areal nonpoint-source watershed environment response simulation (ANSWERS), ANSWERS-Continuous, Cascade of planes in 2-dimensions (CASC2D), DWSM, HSPF, KINEROS, MIKE SHE, PRMS, and SWAT. AGNPS, AnnAGNPS, ANSWERS, ANSWERS-Continuous, CASC2D, dynamic watershed simulation model (DWSM), hydrologic simulation program-Fortran (HSPF), kinematic runoff and erosion model (KINEROS), the European hydrological system model (MIKE SHE), precipitation-runoff modeling system (PRMS), and the soil and water assessment tool 
(SWAT) are event-based models. AnnAGNPS, ANSWERS-Continuous, HSPF, and SWAT are continuous-based models designed to simulate long-term (i.e. multiple years) effects of climate and land use on hydrologic processes. Conversely, AGNPS, ANSWERS, DWSM, and KINEROS are short-term hydrologic models designed to simulate single-event storms, and CASC2D, MIKE SHE, and PRMS have long-term and short-term attributes. Borah and Bera (2003a) indicated SWAT and HSPF were the most efficient (i.e. robust) and comprehensive (i.e. more fully developed) long-term watershed models tested by Borah and Bera (2003a). In another literature review, Borah and Bera (2003b) showed that SWAT and HSPF were suited for simulations of annual stream flow, sediment and nutrient yields, but extreme events following increased urbanization confounded monthly simulations of stream flow, and daily simulations of extreme events were relatively poor. Borah and Bera (2003b) concluded a need for additional model testing (model evaluation, calibration and validation) using quality monitoring data sets, particularly sediment and nutrients.

SWAT is a semi-distributed continuous-time physically-based hydrologic model that works at a daily time step. SWAT can be used to simulate land use practice impacts on water, sediment, and chemical yields over long time periods in large basins (Arnold et al., 2012). Input data needed to run SWAT include climate variables (i.e. precipitation, solar radiation, minimum and maximum air temperature, wind speed, and relative humidity), topographic information, soils, and land use and land cover. Climate variables can be user defined or generated using a weather generator termed WXGEN. Model inputs are lumped into hydrological response units (HRU's) each unique in slope, soil, land use, and management combinations (Neitsch et al., 2009). 
The SWAT model is water balance driven and was designed to operate in two main phases; the land phase (overland pollutant loading to the main channel), and the routing phase (in-stream pollutant transport). During the land phase, runoff is computed for each HRU using the Soil Conservation Service (SCS) curve number procedure, and erosion is calculated using the Modified Universal Soil Loss Equation (MUSLE). The end user can choose between three options to simulate evaporation and transpiration (ET) including 1). Penmann-Monteith, 2) Priestley-Taylor, and 3) Hargreaves. In the routing phase, the end user can choose between two methods to route water in the main channel including 1) the variable storage method, and 2) the Muskingum routing method. Sediment routing is a function of deposition and degradation with user options to simulate down cutting and channel widening. Additionally, SWAT can be used to simulate instream nutrient and pesticide transformations, and bacteria and heavy metal routing. Autocalibration software (e.g. SWAT-cup) and other tools (e.g. the manual calibration helper, SWAT check) have been created to assist with model calibration. Moriasi et al., (2007) presented in a literature review multiple studies where authors have tested SWAT model outputs of streamflow successfully at monthly time steps. Streamflow data sets that can be used to calibrate the SWAT model are readily available from online databases (e.g. U.S. Geological Survey websites), but time series of sediment and nutrient data are rare. Thus, there is a great need for calibration and validation of SWAT model sediment and nutrient simulations (Moriasi et al., 2007). Model end-users fortunate enough to have sufficient time series data have attempted to calibrate and validate SWAT estimates of streamflow, sediment, and nutrients with some success in agricultural watersheds of the central U.S. (Baffaut et al., 2009; Baffaut et al., 
2015). Nutrient yields are generally more difficult to simulate because nutrient transport and transformations remain poorly understood (Poor and McDonnell, (2007). Additionally, error in model output propagates from streamflow, to sediment, to nutrients because nutrient simulations are dependent on sediment simulations, which are in-turn dependent on stream flow simulations. To provide confidence in SWAT model predictions in urbanizing watersheds of the central USA, SWAT model output (streamflow, sediment, and nutrients) must be tested using multiple years of observed data.

\section{Statement of Need}

There is a need to reduce SS and nutrient pollution to receiving water bodies to conserve valuable soil and water resources. However, anthropogenic suspended sediment (SS) and nutrient contributions to riverine systems confound water quality management through direct and indirect impacts to aquatic ecosystem health (Cheviron et al., 2014). To assist land management, science-based information is needed to improve understanding of the relationships between land use and pollutant loading to receiving water bodies (Cheviron et al., 2014). Such an understanding will be important for developing effective best management practices (BMP's) as urban development continues to alter aquatic ecosystem health (Palmer et al., 2008; Kaushal et al., 2008).

Robust hydrologic models may be useful tools for testing the long-term outcomes of BMP's on pollutant yields from urbanizing watersheds (Gassman et al., 2009; Bracmort et al., 2006). However, the models must first be validated using multiple years of observed data to quantify model uncertainty and improve model predictive confidence (Arnold et al., 2012). Studies with results from a SWAT model calibrated and validated 
to streamflow, sediment, and nutrients in rapidly urbanizing watersheds are rare (Moriasi et al., 2007). Therefore, there is a need to test the SWAT model before it can be deemed a suitable tool for land management.

\section{Objectives}

The overall objective of the current research was to quantify spatio-temporal SS and nutrient regimes using a nested-scale experimental watershed study design. Subobjectives were to quantify relationships in land use and a) suspended sediment concentrations, and b) nutrient concentrations in the study catchment, and c) validate SWAT model estimations of monthly streamflow, sediment, and nutrients in a rapidly urbanizing mixed-land use watershed of the central USA. The SWAT model was chosen for the current study because the input data requirements were available, the temporal and spatial scales were appropriate, and the SWAT model is equipped to simulate the effects of climate and land use practices on suspended sediment and nutrient yields in watersheds with agricultural, forest, and urban land uses.

\section{Dissertation Structure}

This dissertation is presented in five chapters. In chapter one, "Introduction", background information important to justify the current work is presented. In chapter two, "Quantifying Suspended Sediment Flux in a Mixed-Land Use Urbanizing Watershed using a Nested-Scale Study Design", a nested scale experimental watershed study design was used to investigate suspended sediment loading at five gauging sites during the 2011, 2012, 2013 water years. In chapter three, "Nested-Scale Nutrient Yields from a Mixed-Land Use Urbanizing Watershed", a nested scale experimental watershed study design was used to investigate nutrient loading a five gauging sites during the 2011, 
2012, 2013 water years. In chapter four, "Nested-Scale SWAT Model Estimations of Stream Flow, Sediment and Nutrients from a Mixed-Land Use Watershed of the Central USA", a nested scale experimental watershed study design was used to assess SWAT model output suspended sediment loading a five gauging sites during the 2011, 2012, 2013 water years. In chapter five, "Conclusions and Synthesis", key findings are presented and potential future research is discussed. 


\section{Literature Cited}

Alexander RB, Smith RA, Schwarz GE, Boyer EW, Nolan JV, Brakebill JW. 2007. Differences in phosphorus and nitrogen delivery to the Gulf of Mexico from the Mississippi River Basin. Environmental Science \& Technology, 42(3), 822-830.

American Society for Testing and Materials (ASTM). 2007. D 3977 - 97 Standard Methods for Determining Sediment Concentrations in Water Samples.

Arnold JG, Moriasi DN, Gassman PW, Abbaspour KC, White MJ, Srinivasan R, Santhi C, Harmel RD, van Griensven A, Van Liew MW, Kannan N, Jha MK. 2012. SWAT: Model use, calibration, and validation. Transactions of the ASABE, 55(4): 1491-1508

Baffaut C, Sadler JE, Lerch RN, and Kitchen NR. 2009. Nutrient sources and transport from the Goodwater Creek Experimental Watershed. Pap. 097150. American Society of Agricultural and Biological Engineers, St. Joseph, MI.

Baffaut C, Sadler JE, Ghidey F, Anderson SH. 2015. Long-Term Agroecosystem Research in the Central Mississippi River Basin: SWAT Simulation of Flow and Water Quality in the Goodwater Creek Experimental Watershed. Journal of Environmental Quality, 44:84-96.

Bolstad, P.V., Swank, W.T., 1997. Cumulative impacts of land use on water quality in a Southern Appalachian watershed. JAWRA, 33: 519-533.

Borah DK, Arnold JG, Bera M, Krug EC, Liang X-Z. 2007. Storm Event and Continuous Hydrologic Modeling for Comprehensive and Efficient Watershed Simulations. Journal of Hydrologic Engineering, 12( 6): 605-616.

Bracmort KS, Arabi M, Frankenberger JR, Engel BA, Arnold JG. 2006. Modeling longterm water quality impact of structural BMPs. Transactions of the ASABE, 49(2), $367-374$.

Carpenter SR, Caraco NF, Correll DL, Howarth RW, Sharpley AN, Smith VH. 1998. Nonpoint pollution of surface waters with phosphorus and nitrogen. Ecological Applications, 8: 559-568.

Chang C-H, Wen C-G, Huang C-H, Chang S-P, Lee C-S. 2008. Nonpoint source pollution loading from an undistributed tropic forest area. Environ. Monit. Assess., 146:113-126. 
Cheviron B, Delmas M, Cerdan O, Mouchel J.-M. 2014. Calculation of river sediment fluxes from uncertain and infrequent measurements. Journal of Hydrology, 508: 364-373.

Chin A. 2006. Urban transformation of river landscapes in a global context. Geomorphology, 79: 460-487.

Clark GM, Gregory M, David K, Mueller DK, and Mast MA. 2000. Nutrient concentrations and yields in undeveloped stream basins of the United States. JAWRA, 36(4): 849-860.

Clark GM, Mueller DK, Mast MA. 1999. Nutrient concentrations and yields in undeveloped stream basins of the United States. JAWRA, 36(4): 849-860.

Dodds WK, Bouska WW, Eitzmann JL, Pilger TJ, Pits KL, Riley AJ, Schloesser JT, Thornbrugh DJ. 2009. Eutrophication of U.S. Freshwaters: Analysis of Potential Economic Damages. Environmental Science and Technology, 43(1): 12-19.

Dodds WK, Whiles MR. 2004. Quality and Quantity of Suspended Particles in Rivers: Continent-Scale Patterns in the United States. Environmental Management, 33(3): $355-367$.

Floyd WC, Schoenholtz SH, Griffith SM, Wigington PJ, Steiner JJ. 2009. Nitratenitrogen, land use/land cover, and soil drainage associations at multiple spatial scales. Journal of Environmental Quality, 38:1473-1482.

Fontaine, T. A., Cruickshank, T. S., Arnold, J. G., \& Hotchkiss, R. H. (2002). Development of a snowfall-snowmelt routine for mountainous terrain for the soil water assessment tool (SWAT). Journal of hydrology, 262(1), 209-223.

Groffman PM, Law NL, Belt KT, Band LE, Fisher GT. 2004. Nitrogen fluxes and retention in urban watershed ecosystems. Ecosystems, 7: 393-403.

Guo J, Zhang Z, Zhou J, Wang S, Strauss P. 2014. Decoupling Streamflow Responses to Climate Variability and Land Use/Cover Changes in a Watershed in Northern China. JAWRA, 50(6), 1425-1438.

Heimann DC, Sprague LA, Blevins DW. 2011. Trends in Suspended-Sediment Loads and Concentrations in the Mississippi River Basin, 1950-2009. U.S. Geological Survey Scientific Investigations Report 2011-5200, 33 p. 
Hollister JW, August PV, Paul JF. 2008. Effects of spatial extent on landscape structure and sediment metal concentration relationships in small estuarine systems of the United States' Mid-Atlantic Coast. Landscape Ecology, 23: 91-106.

Howarth RW, Billen G, Swaney D, Townsend A, Jaworski N, Lajtha K, Downing JA, Elmgren R, Caraco T, Jordan T, Berendse F, Freney J, Kudeyarov V, Murdoch P, Zhu ZL. 1996. Regional nitrogen budgets and riverine N \& P fluxes for the drainages to the North Atlantic Ocean: Natural and human influences. Biochemistry, 35(1): 75-139.

Hubbart JA, and Zell C. 2013. Considering streamflow trend analyses uncertainty in urbanizing watersheds: a base flow case study in the central United States. Earth Interactions, 17(5): 1-28.

Hubbart JA, Gebo NA. 2010. Quantifying the effects of land-use and erosion by particle size class analysis in the central U.S. Erosion Control Journal, 17(7): 1-4.

Hubbart JA, Holmes J, Bowman G. 2010. Integrating science based decision making and TMDL allocations in urbanizing watersheds. The Watershed Science Bulletin, 01: 19-24.

Hubbart JA, Kellner E, Freeman G. 2013. A case study considering the comparability of mass and volumetric suspended sediment data. Environmental Earth Science, 71(9): 4051-4060.

Hubbart JA, Kellner E, Lynne H, Lupo AR, market PS, Guinan PE, Stephan K, Fox NI, Svoma, BM. 2014. Localized climate and surface energy flux alterations across an urban gradient in the central US. Energies, 7: 1770-1791.

Hubbart JA. 2011. Urban Floodplain Management. Stormwater, (September, 2011): 5663.

Jordan BA, Annable WK, Watson CC, Sen D. 2010. Contrasting stream stability characteristics in adjacent urban watersheds: Santa Clara Valley, California. River Res. Applic, 26: 1281-1297.

Jordan TE, Correll DL, Weller, DE. 1997. Relating nutrient discharges from watersheds to land use and streamflow variability. Water Resources Research, 33: 25792590. 
Kaushal SS, Groffman PM, Band LE, Shields CA, Morgan RP, Palmer MA, Belt KT, Swan CM, Findlay SEG, Fisher GT. 2008. Interaction between Urbanization and Climate Variability Amplifies Watershed Nitrate Export in Maryland. Environmental Science \& Technology, 42(16): 5872-5878.

Kellner E, Hubbart JA, Thomas S. 2014. Quantifying urban land-use impacts on suspended sediment particle size class distribution. Stormwater, 15(2): 40.

Koirala AM. 2009. An Evaluation of Pre- and Post-Timber Harvest Water Quality in Low-Order Streams in the Missouri Ozarks. PhD Dissertation, Graduate School, University of Missouri-Columbia

Kreutzweiser DP, Capell SS. 2001. Fine sediment deposition in streams after selective forest harvesting without riparian buffers. Can. J. For. Res., 31: 2134-2142.

Lamba J, Thompson AM, Karthikeyan KG, Fitzpatrick FA. 2015. Sources of fine sediment stored in agricultural lowland streams, Midwest, USA. Geomorphology, 236: 44-53.

Leopold LB, Wolman MG, Miller JP. 2012. Fluvial processes in geomorphology. Courier Corporation.

Lerch RN, Kitchen NR, Baffaut C, Vories ED. 2015a. Long-term agroecosystem research in the Central Mississippi River Basin: Goodwater Creek Experimental Watershed and regional nutrient water quality data. Journal of Environmental Quality, 44: 37-43.

Lerch RN, Baffaut C, Kitchen NR, Sadler EJ. 2015b. Long-term agroecosystem research in the Central Mississippi River Basin: Dissolved nitrogen and phosphorus transport in a high-runoff-potential watershed. Journal of Environmental Quality, 44: 44-57.

Letcher RA, Jakeman AJ, Merritt WS, McKee LJ, Eyre BD, Baginska B. 1999. Review of Techniques to Estimate Catchment Exports, Environment Protection Authority, Sydney.

MDNR. 2006. Stream Survey Sampling Report. Phase III Hinkson Creek Stream Study, Columbia, Missouri, Boone County. Prepared by the Missouri Department of Natural Resources, Field Services Division, Environmental Services Program, Water Quality Monitoring Section. 
Miller D, Vandike J. 1997. Groundwater resources of Missouri. Missouri Department of Natural Resources Division of Geology and Land Survey Water Resources Rep. 46., $136 \mathrm{pp}$.

Moriasi DN, Arnold JG, Van Liew MW, Bingner RL, Harmel RD, Veith TL. 2007. Model evaluation guidelines for systematic quantification of accuracy in watershed simulations. American Society of Agricultural and Biological Engineers, 50(3): 885-900.

Nelson EJ, Booth DB. 2002. Sediment sources in an urbanizing, mixed land-use watershed. Journal of Hydrology, 264: 51-68.

Palmer MA, Reidy C, Nilsson C, Florke M, Alcamo J, Lake PS, Bond N. 2008. Climate change and the world's river basins: Anticipating management options. Frontiers Ecol. Environ., 6(2): 81-89.

Poor CJ, McDonnell JJ. 2007. The effects of land use on stream nitrate dynamics. Journal of Hydrology, 332(1-2): 54-68.

Quilbe R, Rousseau AN, Duchemin M, Poulin A, Gangbazo G, Villeneuve JP. 2006. Selecting a calculation method to estimate sediment and nutrient loads in streams: application to the Beaurivage River (Quebec, Canada). Journal of Hydrology, 326(1-4): 295-310.

Royer TV, David MB, Gentry LE. 2006. Timing of riverine export of nitrate and phosphorus from agricultural watersheds in Illinois: Implications for reducing nutrient loading to the Mississippi River. Environmental Science \& Technology, 40: 4126-4131.

Schottler SP, Ulrich J, Belmont P, Moore R, Lauer JW, Engstrom DR, Almendinger JE. 2014. Twentieth century agricultural drainage creates more erosive rivers. Hydrological Processes, 28: 1951-1961.

Shields CA, Band LE, Law N, Groffman PM, Kaushal SS, Savvas K, Fisher GT, Belt KT. 2008. Streamflow distribution of non-point source nitrogen export from urban-rural catchments in the Chesapeake Bay watershed. Water Resources Research, 44: W09416 
Taylor KG, Owens PN. 2009. Sediments in urban river basins: a review of sedimentcontaminant dynamics in an environmental system conditioned by human activities. J Soils Sediments, 9: 281-303.

Trimble S. 2009. Fluvial processes, morphology and sediment budgets in the Coon Creek Basin, WI, USA, 1975-1993. Geomorphology, 108: 8-23.

Turner RE, Rabalais NN. 2004. Suspended sediment, C, N, P, and Si yields from the Mississippi River Basin. Hydrobiologia, 511: 79-89.

Turner RE, Rabalais NN. 2003. Linking landscape and water quality in the Mississippi River Basin. BioScience, 53: 563-572.

United States Census Bureau (USCB). 2014. U.S. Census Bureau: State and County Quick Facts. Available on line at: http://quickfacts.census.gov/qfd/states/29000.html

Walling DE. 2006. Human impact on land-ocean sediment transfer by the world's rivers. Geomorphology, 79: 192-216.

Walling DE. 2013. Changing fluvial sediment inputs to the world's deltas. Proceedings of HP1, IAHS-IAPSO-IASPEI Assembly, Gothenburg, Sweden, 358: 12-26.

Walsh CJ, Roy AH, Feminella JW, Cottingham PD, Groffman PM, Morgan II RP. 2005. The urban stream syndrome: current knowledge and the search for a cure. Journal of the North American Benthological Society, 24(3): 706-723.

Zhou B, He HS, Nigh TA, Schulz JH. 2012. Mapping and analyzing change of impervious surface for two decades using multi-temporal Landsat imagery in Missouri. International Journal of Applied Earth Observation and Geoinformation, 18: 195-206. 


\title{
CHAPTER II
}

QUANTIFYING SUSPENDED SEDIMENT FLUX IN A MIXED-LAND USE

URBANIZING WATERSHED USING A NESTED-SCALE STUDY DESIGN

In Print:

Zeiger, S., and J.A. Hubbart. 2016. Quantifying Suspended Sediment Flux in a MixedLand Use Urbanizing Watershed using a Nested-Scale Study Design. Science of the Total Environment. DOI: 10.1016/j.scitotenv.2015.10.096

\begin{abstract}
Suspended sediment (SS) remains the most pervasive water quality problem globally and yet, despite progress, SS process understanding remains relatively poor in watersheds with mixed-land-use practices. The main objective of the current work was to investigate relationships between suspended sediment and land use types at multiple spatial scales $(n=5)$ using four years of suspended sediment data collected in a representative urbanized mixed-land-use (forest, agriculture, urban) watershed. Water samples were analyzed for SS using a nested-scale experimental watershed study design ( $n=836$ samples $\times 5$ gauging sites). Kruskal-Wallis and Dunn's post-hoc multiple comparison tests were used to test for significant differences $(C I=95 \%, p<0.05)$ in $\mathrm{SS}$ levels between gauging sites. Climate extremes (high precipitation/drought) were observed during the study period. Annual maximum SS concentrations exceeded 2387.6 $\mathrm{mg} \mathrm{L}^{-1}$. Median SS concentrations decreased by $60 \%$ from the agricultural headwaters to the rural/urban interface, and increased by $98 \%$ as urban land use increased. Multiple linear regression analysis results showed significant relationships between SS, annual
\end{abstract}


total precipitation (positive correlate), forested land use (negative correlate), agricultural land use (negative correlate), and urban land use (negative correlate). Estimated annual SS yields ranged from 16.1 to $313.0 \mathrm{t} \mathrm{km}^{-2}$ year ${ }^{-1}$ mainly due to differences in annual total precipitation. Results highlight the need for additional studies, and point to the need for improved best management practices designed to reduce anthropogenic SS loading in mixed-land-use watersheds.

\section{Introduction}

Anthropogenic suspended sediment (SS) contributions to riverine systems can detrimentally impact aquatic ecosystem condition (Cheviron et al., 2014). While SS can supply nutrients to aquatic food webs (Dodds and Whiles, 2004; Koirala, 2009), excessive SS concentration can reduce primary productivity, decrease invertebrate and fish populations, and smother benthic habitats (Bilotta and Brazier, 2008; Lamba et al., 2015). Additionally, agricultural chemicals adsorbed to SS contribute to water toxicity, eutrophication, and hypoxia of receiving water bodies (Bilotta and Brazier, 2008). For example, eutrophication of freshwater ecosystems alone costs an estimated $\$ 2.2$ billion dollars annually in the USA (Dodds et al., 2008). Associated hypoxic zones in coastal waters are growing in size and persistence (Rabotyagov et al., 2014). It is therefore not surprising that multiple authors have stressed the need to mitigate water quality problems associated with pollutant loading to conserve water resources (Rabalais et al., 2010; Heimann et al., 2011; Lamba et al., 2014; Rabotyagov et al., 2014).

Agriculture, urban development, deforestation and mining are historically linked to soil loss and increased sediment yield (Walling, 2006). For example, sediment loss in the Mississippi River Basin (MRB) was greatest following land clearing and plowing 
during European settlement in the 1800's (Turner and Rabalais, 2003). More recently, Turner and Rabalais (2004) estimated an average sediment yield of $52.3 \mathrm{t} \mathrm{km}^{-2}$ from the MRB to Gulf of Mexico from 1973 to 1994. Chin (2006) showed land surface cleared for urban development, and left for more than one year, can lead to sediment yields greater than $10,000 \mathrm{t} \mathrm{km}^{-2} \mathrm{yr}^{-1}$. While soil conservation efforts have helped to conserve soil resources (Walling, 2013), water resource problems associated with excessive sediment yields may not be mitigated for decades without corresponding efforts to reduce channel incision and bank erosion (Trimble, 2009). For example, Trimble (2009) showed conservation practices reduced overland soil erosion in Coon Creek Basin, but sediment yield was unabated mainly due to increased stream bed and bank erosion. Trimble (2009) concluded that reduction in sediment yields may be more dependent on stream bank stabilization, construction of fish shelter structures and conservation of riparian vegetation. Obviously there is a need to reduce SS loading to conserve soil and water resources. However, complex interactions of natural and anthropogenic impacts complicate attempts to develop effective management plans. Additional science-based information is needed to improve understanding of the effects of land use practices on SS yields at the watershed scale.

Increased impervious surfaces and engineered waterways alter natural sediment transport processes (Taylor and Owens, 2009). For example, impervious surfaces that cause a flashy hydrologic response to rainfall-runoff events often lead to increased bank wasting, channel incision and scouring (Walsh et al., 2005). Jordan et al. (2010) noted a 9 to $61 \%$ increase of sediment yield due to urban flow regime induced bank instability and channel degradation in Berryessa Creek near San Francisco, California. Nelson and 
Booth (2002) concluded that human activity caused an increase in sediment yield by approximately $50 \%$ to $44 \mathrm{t} \mathrm{km}^{-2} \mathrm{yr}^{-1}$ in a mixed-land use urbanized watershed of western Washington State. Kellner and Hubbart (2014) in the central USA, noted that SS originating from urban subbasins had greater concentrations of fine sediments relative to rural subbasins.

Hollister et al., (2008) showed relationships between land use and land cover (LULC) and SS loading regimes change depending on the spatial extent considered (Hollister et al., 2008). Generally, deforestation, as well as agricultural and urban land uses are cited as sediment-generating activities while forests and wetlands are usually sediment sinks (Meybek et al., 2003; Nelson and Booth, 2002; Schottler et al., 2014; Lamba et al., 2015). Investigations of the effects of mixed-land use practices on sediment yields at multiple spatial and temporal scales remains a rich avenue for research given the complex nature of the problem thus providing the motivation for the present work. The objectives of the current investigation were to a) quantitatively characterize the suspended sediment regime, b) investigate relationships between suspended sediment and land use types, and c) estimate sediment loading and yields at multiple spatial scales $(n=5)$ using four years of suspended sediment data collected in an urbanized mixed-landuse watershed of the central USA.

\section{Methods}

Study area

The study catchment, Hinkson Creek Watershed (HCW), is a rapidly urbanizing mixed-land use (forest, agriculture, urban) watershed located in the Lower Missouri Mississippi River Basin (LMMRB) with a drainage area of approximately $230 \mathrm{~km}^{2}$. 
Elevation ranges from $274 \mathrm{~m}$ above mean sea level (AMSL) in the headwaters to $177 \mathrm{~m}$ AMSL near the watershed outlet. At the time of this work, agricultural land use dominated HCW (35.9\%) with other land uses including $28.4 \%$ grazing pasture and $7.5 \%$ row crop and $32.1 \%$ forested mixed deciduous forest land cover. Urban and suburban areas accounted for $28.9 \%$ of the total land use (Table 2.1). Urban land use in the lower reaches of HCW was associated with approximately $28 \mathrm{~km}^{2}$ of impervious surfaces within the municipal boundary of the City of Columbia (population 113,225; USCB, 2014) (Zhou et al., 2012).

Soils corresponding to the Mexico-Leonard association in the upper elevations of HCW are generally loamy loess with a well-developed underling claypan in the argillic horizon of smectitic minerals (Hubbart and Zell, 2013). Claypan soils have increased surface runoff potential (Lerch et al., 2015a). Hubbart (2011) showed alluvial soils have infiltration rates that range greatly $\left(0.1\right.$ to $\left.126.0 \mathrm{~cm} \mathrm{hr}^{-1}\right)$ between agricultural sites and bottomland hardwood forest sites in the lower reaches of HCW. Soils that consist of a cherty clay solution residuum corresponding to the Weller-Bardley-Clinkenbeard (CBC) association are also found in the lower reaches (upland of the alluvium). Soils in HCW are underlain by Burlington formation Mississippian series limestone in the lower reaches (Miller and Vandike 1997; Hubbart and Zell, 2013).

Climate in $\mathrm{HCW}$ is dominated by continental polar air masses in the winter and maritime and continental tropical air masses in the summer (Hubbart et al., 2010). A 16year climate record (2000-2014) obtained from the Sanborn Field climate station located on University of Missouri campus showed mean annual total precipitation was $1036 \mathrm{~mm}$, and mean annual air temperature was $13.3^{\circ} \mathrm{C}$. Daily minimum and maximum air 
temperatures ranged from $-23.1{ }^{\circ} \mathrm{C}$ in the winter to $41.3{ }^{\circ} \mathrm{C}$ in the summer. Thus, soils and underlying bedrock are subject to freeze-thaw conditions that have been long known to increase the rate of erosion (Leopold et al., 1964). The wet season occurs primarily during March through June (Hubbart et al., 2010, Hubbart et al., 2014). The HCW main drainage, Hinkson Creek, is primarily stormflow dominated with a base flow index (ratio of base flow to total streamflow) of approximately 0.25 calculated using daily discharge data collected at a U.S. Geological Survey (USGS) gaging station (USGS 06910230, Site \#Site \#4 in Figure 2.1) that has been intermediately monitoring stage since 1967.

Hinkson Creek was included on the Clean Water Act 303(d) list of impaired waters in 1998. During winter 2008, HCW was instrumented with a nested-scale experimental study design. Gauging sites $(n=5)$ partitioned the catchment into five subbasins, each with different dominant land uses to investigate land use impacts on water quantity and quality (Hubbart et al., 2010). Site \#5 is located near the watershed outlet, and Sites \#1 to \#4 are nested within (Figure 2.1). Precipitation and stage were continuously monitored at gauging stations located at each gauging site $(n=5)$ during the four year study period (2010-2013). Stage data and manually measured stream flow were used for the development of stage-discharge rating curves for each gauging site. 
Table 2.1. Cumulative drainage area, land use and land cover area to each gauging site located in Hinkson Creek Watershed (HCW), Missouri, USA.

\begin{tabular}{lllllll}
\hline LULC (ha) & Site \#1 & Site \#2 & Site \#3 & Site \#4 & Site \#5 & HCW \\
\hline Open water & 38.5 & 53.3 & 58.1 & 109.0 & 135.0 & 146.0 \\
Residential $\dagger$ & 355.5 & 536.6 & 1027.5 & 2430.3 & 3726.9 & 4623.2 \\
Urban§ & 4.9 & 91.0 & 442.8 & 1242.3 & 1716.2 & 2103.8 \\
Barren & 1.3 & 29.0 & 30.9 & 41.0 & 41.5 & 42.0 \\
Forested & 2842.8 & 3754.3 & 4109.2 & 6276.4 & 6863.5 & 7485.6 \\
Grassland & 88.3 & 105.6 & 109.4 & 166.9 & 178.1 & 194.0 \\
Grazing pasture & 3533.0 & 4358.3 & 4438.0 & 6021.2 & 6106.5 & 6604.5 \\
Row crop & 879.2 & 1168.7 & 1209.2 & 1660.6 & 1682.2 & 1743.3 \\
Wetland & 152.4 & 188.2 & 194.0 & 251.5 & 300.4 & 341.2 \\
Area & 7895.9 & 10284.8 & 11618.9 & 18199.1 & 20750.3 & 23283.6 \\
\hline
\end{tabular}

$\dagger$ Residential LULC area was defined as urban land use with less than $50 \%$ imperviousness.

§Urban LULC area was defined as urban land use with greater than $50 \%$ imperviousness. 


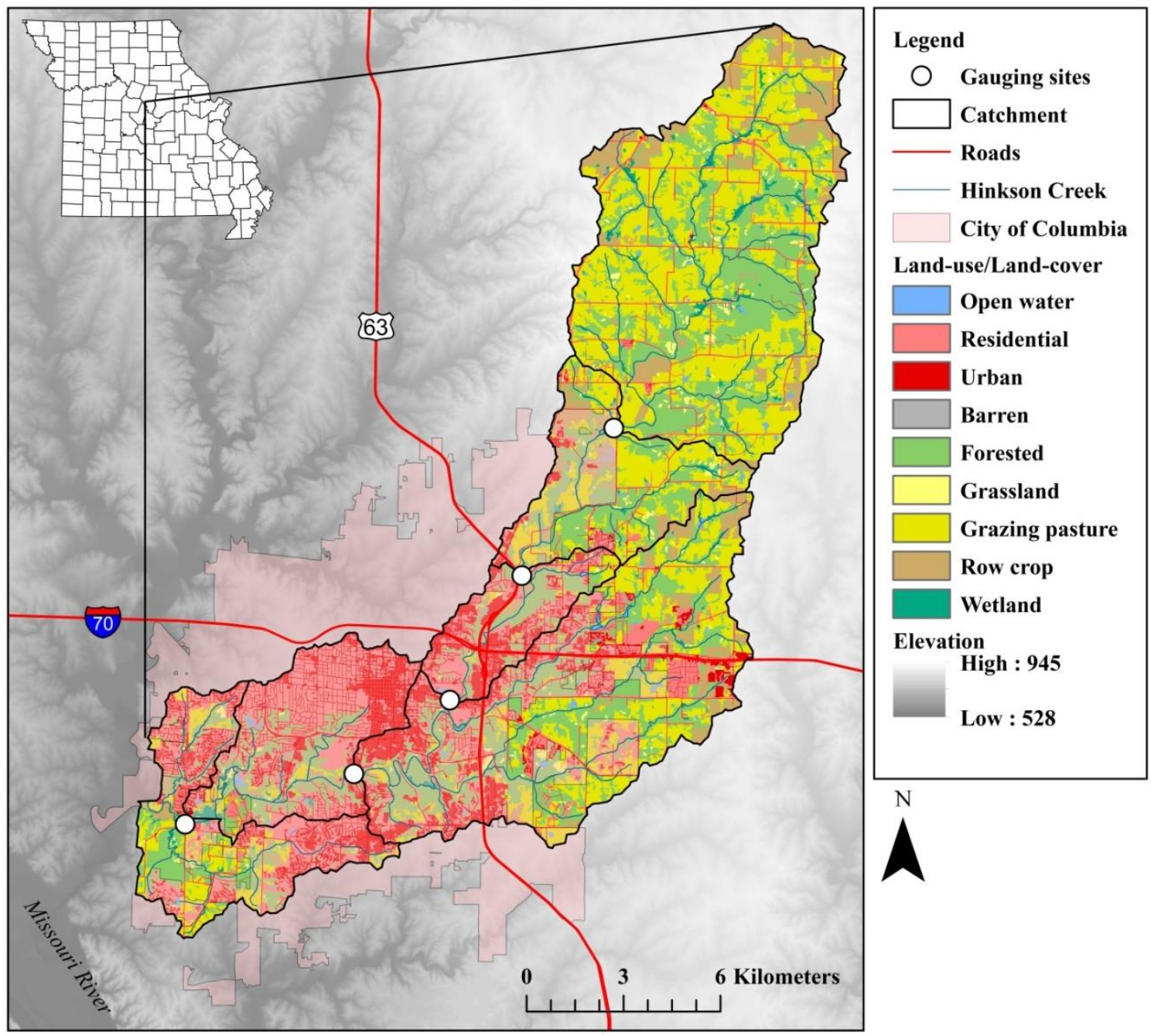

Figure 2.1. Nested-scale experimental watershed study design including five gauging sites located in Hinkson Creek Watershed, Missouri, USA.

\section{Suspended sediment concentrations}

Stream water grab samples were collected on Monday, Wednesday, Friday and Saturday at the same time of day at each nested monitoring site for four years (2010 2013, $n=836$ samples per site). Water samples were refrigerated and gravimetric analyses (vacuum filtration) were conducted within a few days of collection (ASTM, 2007).

Duplicates ( $n=390)$ were collected on a monitoring site rotation Monday and Wednesday 
every week. Kruskal-Wallis tests showed no significant differences $(C I=95 \%, p>0.959$, $n=390$ ) between samples and corresponding duplicates.

Averaging observed sediment concentrations over time can lead to bias due to differences in discharge and sampling timing over the period of averaging. A broadly accepted solution to avoid this bias is to calculate flow-weighted mean SS concentrations (FWC) (Clark et al., 2000; Chang et al., 2008). For the present study, FWC's were calculated at monthly, seasonal (quarterly), and annual time steps to characterize SS concentration regimes at each site. Quarterly time steps included January through March $\left(1^{\text {st }}\right.$ quarter$)$, April through June ( $2^{\text {nd }}$ quarter $)$, July through September ( $3^{\text {rd }}$ quarter $)$, and October through December ( $4^{\text {th }}$ quarter$)$.

\section{Sediment rating curves and yield}

Daily discharge data were averaged from 5-minute values for loading calculations, and are presented as annual SS loads $\left(\mathrm{t} \mathrm{km}^{-2}\right)$ and yields $\left(\mathrm{t} \mathrm{km}^{-2} \mathrm{yr}^{-1}\right)$. There is no optimum method to calculate SS load (Letcher et al., 1999; Quilbe et al., 2006). Therefore, multiple methods were used in the present research including linear interpolation, average sample load, average sample concentration times average sample discharge, and log space discharge-concentration regression (sediment rating curves) (Letcher et al., 1999). Equations for the four methods are dependent on sediment

concentration $(C)$ in $\mathrm{m} \mathrm{L} \mathrm{L}^{-1}$, discharge $(Q)$ in $\mathrm{L} \mathrm{s}^{-1}$ at the time of sampling, time $(t)$ in seconds, the time interval of yield in seconds $(K)$, and sample size (n) (Table 2.2). 
Table 2.2. Four methods used to calculate sediment yields.

\begin{tabular}{lll}
\hline Method \# & Method description & Equation \\
\hline Method 1 & Linear Interpolation & $L_{1}=\sum_{i=1}^{n+1} \sum_{t_{i}<t \leq t_{i+1}}^{i} Q_{t}\left(\frac{C_{t_{i}}\left(t_{i+1}-t\right)+C_{t_{i+1}}\left(t-t_{i}\right)}{t_{i+1}-t}\right)$ \\
Method 2 & $\begin{array}{l}\text { Average sample load } \\
\text { Method } 3\end{array}$ & $\begin{array}{l}\text { Average sample } \\
\text { concentration x } \\
\text { average sample } \\
\text { discharge }\end{array}$ \\
Method 4 & $\begin{array}{l}\text { Log space discharge- } \\
\text { concentration } \\
\text { regression }\end{array}$ & $L_{3}=K\left(\frac{1}{n} \sum_{i=1}^{n} C_{i} Q_{i}\right)$ \\
\hline
\end{tabular}

Concentration is $C, Q$ is discharge at the time of sampling, $t$ is time, $K$ is the time interval of yield in seconds, $n$ is sample size.

\section{Statistical analysis}

Kruskal-Wallis and Dunn's post-hoc multiple comparison tests were used to test for significant differences $(C I=95 \%, p<0.05)$ in median observed SS concentrations, FWC's, sediment loads and sediment yields between gauging sites (Lerch et al., 2015b). Kruskal-Wallis and Dunn's post-hoc multiple comparison tests were chosen because hydrologic data were not normally distributed. Stepwise regression techniques were used to test for significant relationships between suspended sediment data, precipitation, drainage area, and land use indices $(C I=95 \%, \alpha=0.05)$ (Lerch et al., 2015b) including open water, residential, urban, barren, forested, grassland, grazing pasture, row crop, and wetland.

\section{Results}

Four-year average annual precipitation ranged from $974 \mathrm{~mm}$ at Site \#Site \#2 to $1007 \mathrm{~mm}$ at Site \#Site \#3, with a five-site average of $991 \mathrm{~mm}$ during the study period (2010-2013). Annual total precipitation was highly variable during the study ranging 
from $639 \mathrm{~mm}$ at Site \#Site \#2 during 2012, the driest year of the study period, to 1342 mm at Site \#Site \#3 during 2010. Year 2010 was the $3^{\text {rd }}$ consecutive record-setting precipitation year. The great variability in precipitation translated to variability in streamflow where maximum daily average streamflow peaked at $138.8 \mathrm{~m}^{3} \mathrm{~s}^{-1}$ at Site \#Site \#5 near the watershed outlet during 2010. During 2012, the year of drought, maximum daily average streamflow was estimated to be $52.8 \mathrm{~m}^{3} \mathrm{~s}^{-1}$ at Site \#5. Daily median streamflow was less than $0.1 \mathrm{~m}^{3} \mathrm{~s}^{-1}$ at Site \#Site \#1 during the study period. Base flow indices ranged from $0.17,0.20,0.20,0.25,0.27$ in order from Sites \#1 to \#5, respectively, indicating that the stream was surface flow dominated from the headwaters at Site \#Site \#1, to Site \#Site \#5 near the watershed outlet.

\section{Suspended sediment concentrations}

Annual maximum observed SS concentrations ranged from $348.2 \mathrm{mg} \mathrm{L}^{-1}$ (Site \#Site \#5 during 2012) to $2387.6 \mathrm{mg} \mathrm{L}^{-1}$ (Site \#Site \#4 during 2010) throughout the four year study period (2010-2013) (Table 2.3). There was a general decreasing trend for annual median observed SS concentrations of $-0.25 \mathrm{mg} \mathrm{L}^{-1} \mathrm{~km}^{-1}$ with downstream distance from the agriculture dominated drainage of Site \#1 (57.0\% agricultural; $4.6 \%$ urban) to the rural/urban interface watershed (Site \#3) (49.8\% agricultural; $12.7 \%$ urban) as agricultural land use decreased by $7.2 \%$. Annual median SS concentration increased by $0.4 \mathrm{mg} \mathrm{L}^{-1} \mathrm{~km}^{-1}$ from Site \#3 to Site \#5 (38.6\% agricultural; $26.2 \%$ urban) as urban land use increased by $13.5 \%$. Multiple linear regression analysis results showed median SS concentrations were significantly dependent $\left(R^{2}=0.504 ; p=0.001\right)$ on annual total precipitation (positive correlate; $p=0.001$ ), and cumulative percent forested land use (negative correlate; $p=0.031$ ). Adding cumulative percent urban land use (negative 
correlate; $p=0.65)$ to the multiple linear regression model increased the explained variance to $58.0 \%\left(R^{2}=0.577 ; p=0.001\right)$. Total annual precipitation (positive correlate; $p=0.001$ ) and agricultural land use (negative correlate; $p=0.09$ ) were also significantly related $\left(R^{2}=0.443 ; p=0.003\right)$ to $\mathrm{SS}$ concentrations.

Table 2.3. Summary of statistics for observed sediment (SS) concentrations $(n=836$ sample days per site) from 2010 - 2013 at five gauging sites measured in Hinkson Creek, Missouri, USA.

\begin{tabular}{|c|c|c|c|c|c|c|}
\hline Date & Statistic & Site \#1 & Site \#2 & Site \#3 & Site \#4 & Site \#5 \\
\hline \multirow[t]{5}{*}{2010} & Mean & 53.5 & 67.7 & 63.1 & 61.2 & 85.0 \\
\hline & Std. Dev. & 153.8 & 189.3 & 166.6 & 196.1 & 225.3 \\
\hline & Min & 0.3 & 0.5 & 0.6 & 0.6 & 1.7 \\
\hline & Median & 12.0 & 13.0 & 12.3 & 11.8 & 19.9 \\
\hline & Max & 1240.0 & 1723.0 & 1486.3 & 2387.6 & 2323.6 \\
\hline \multirow[t]{5}{*}{2011} & Mean & 34.5 & 31.5 & 32.9 & 34.2 & 43.6 \\
\hline & Std. Dev. & 120.2 & 104.3 & 90.7 & 96.7 & 91.8 \\
\hline & Min & 1.1 & 0.7 & 0.8 & 1.6 & 1.9 \\
\hline & Median & 7.6 & 5.4 & 4.8 & 6.6 & 15.7 \\
\hline & Max & 1226.2 & 936.7 & 696.9 & 857.9 & 685.2 \\
\hline \multirow[t]{5}{*}{2012} & Mean & 20.8 & 14.4 & 16.1 & 14.6 & 18.9 \\
\hline & Std. Dev. & 66.1 & 58.4 & 61.2 & 49.6 & 47.8 \\
\hline & Min & 0.5 & 0.3 & 0.7 & 0.6 & 0.8 \\
\hline & Median & 5.0 & 3.0 & 2.0 & 2.9 & 6.9 \\
\hline & Max & 818.3 & 674.7 & 630.0 & 429.0 & 348.2 \\
\hline \multirow[t]{5}{*}{2013} & Mean & 24.7 & 22.4 & 25.1 & 23.3 & 31.0 \\
\hline & Std. Dev. & 104.0 & 95.9 & 100.8 & 84.8 & 87.7 \\
\hline & Min & 0.4 & 0.4 & 0.6 & 0.6 & 1.1 \\
\hline & Median & 5.8 & 3.1 & 3.1 & 3.6 & 6.8 \\
\hline & Max & 1265.6 & 1041.4 & 956.9 & 792.7 & 816.4 \\
\hline Entire & Mean & 33.4 & 32.3 & 33.8 & 34.5 & 45.1 \\
\hline Study & Std. Dev. & 118.7 & 121.5 & 113.3 & 125.7 & 138.6 \\
\hline \multirow[t]{3}{*}{ Period } & Min & 0.3 & 0.3 & 0.6 & 0.5 & 0.3 \\
\hline & Median & 6.7 & 4.3 & 3.6 & 4.8 & 10.5 \\
\hline & Max & 1265.6 & 1723.0 & 1486.3 & 2387.6 & 2323.6 \\
\hline
\end{tabular}

Annual median flow weighted concentrations (FWC's) of suspended sediment are presented for the current work because median values are suitable for hydrologic data 
sets with a skewed distribution. Annual median FWC's of suspended sediment ranged from $217.4 \mathrm{mg} \mathrm{L}^{-1}$ at Site \#Site \#5 to $309.9 \mathrm{mg} \mathrm{L}^{-1}$ at Site \#Site \#2. Seasonal median FWC's ranged from $6.4 \mathrm{mg} \mathrm{L}^{-1}$ at Site \#Site \#2 in the $3^{\text {rd }}$ quarter (July through September), to $391.6 \mathrm{mg} \mathrm{L}^{-1}$ at Site \#Site \#1 in the $2^{\text {nd }}$ quarter (April through June). Monthly median FWC's ranged from $2.8 \mathrm{mg} \mathrm{L}^{-1}$ at Site \#Site \#2 in October, to $330.5 \mathrm{mg}$ $\mathrm{L}^{-1}$ at Site \#Site \#1 in May (Table 2.4). Results from Dunn's multiple comparison test indicated seasonal median FWC's were significantly greater during the $2^{\text {nd }}$ quarter with a mean difference ranging from $240.5 \mathrm{mg} \mathrm{L}^{-1}$ during the $1^{\text {st }}$ and $2^{\text {nd }}$ quarters to $359.8 \mathrm{mg} \mathrm{L}^{-1}$ during the $2^{\text {nd }}$ and $3^{\text {rd }}$ quarters $(p<0.013)$. Seasonal median FWC's were also significantly different during the $1^{\text {st }}$ quarter relative to the $3^{\text {rd }}$ and $4^{\text {th }}$ quarters $(p<0.024)$. When monthly average FWC's were analyzed for significant differences using Dunn's multiple comparison test, results were mixed (Table 2.5). FWC's were significantly greater during the wettest months of the year (April and May), with differences in median monthly FWC's ranging from $46.4 \mathrm{mg} \mathrm{L}^{-1}$ (April and May) to $257.01 \mathrm{mg} \mathrm{L}^{-1}$ (May and October). FWC's were also significantly greater during December relative to October with differences in median monthly FWC's of $9.0 \mathrm{mg} \mathrm{L}^{-1}$. 
Table 2.4. Median monthly, seasonal, and annual $(n=4)$ flow weighted mean sediment concentrations (FWC, mg L ${ }^{-1}$ ) measured at each gauging site in Hinkson Creek, Missouri, USA from $2010-2013$.

\begin{tabular}{lcccccc}
\hline Element & Time & Site \#1 & Site \#2 & Site \#3 & Site \#4 & Site \#5 \\
\hline FWC $\left(\mathrm{mg} \mathrm{L}^{-1}\right)$ & January & 47.0 & 25.9 & 37.3 & 28.1 & 54.1 \\
& February & 87.0 & 79.6 & 138.0 & 84.6 & 101.5 \\
& March & 114.8 & 135.4 & 140.5 & 106.1 & 162.2 \\
& April & 284.1 & 276.0 & 248.2 & 190.8 & 202.7 \\
& May & 330.5 & 309.0 & 265.8 & 234.3 & 299.9 \\
& June & 200.6 & 175.1 & 196.8 & 186.0 & 138.5 \\
& July & 15.2 & 7.4 & 5.4 & 18.6 & 37.6 \\
& August & 24.7 & 8.3 & 39.9 & 46.7 & 37.7 \\
& September & 17.5 & 3.9 & 10.8 & 14.6 & 39.4 \\
& October & 4.3 & 2.8 & 6.9 & 5.0 & 6.7 \\
& November & 7.9 & 6.2 & 12.4 & 11.0 & 8.7 \\
& December & 16.0 & 12.6 & 22.3 & 17.3 & 15.8 \\
\hline FWC $\left(\mathrm{mg} \mathrm{L}^{-1}\right)$ & $1^{\text {st }}$ Quarter & 143.2 & 154.9 & 173.9 & 128.9 & 199.3 \\
& $2^{\text {nd }}$ Quarter & 391.6 & 376.2 & 356.2 & 251.4 & 240.5 \\
& $3^{\text {rd }}$ Quarter & 16.9 & 6.4 & 19.0 & 25.9 & 38.8 \\
& $4^{\text {th }}$ Quarter & 12.8 & 8.9 & 18.2 & 16.5 & 15.4 \\
& Annual & 272.0 & 309.9 & 299.0 & 217.4 & 272.0 \\
\hline
\end{tabular}

Table 2.5. Summary of results ( $p$-values) from Dunn's post-hoc multiple comparison tests for significant differences $(\mathrm{CI}=95 \%)$ between monthly flow weighted mean sediment concentrations (FWC) at each gauging site $(n=5)$ from 2010 - 2013 measured in Hinkson Creek, Missouri, USA. Bold font shows significant differences (p-values less than 0.05). Columns and rows for months where no significant differences were observed are not presented in the table.

\begin{tabular}{|c|c|c|c|c|c|c|c|c|}
\hline & Apr & May & Jul & Aug & Sep & Oct & Nov & Dec \\
\hline Jan & $<0.001$ & $<0.001$ & & & & $<0.001$ & & \\
\hline Feb & & & & & & $<0.001$ & $<0.001$ & \\
\hline Mar & & & $<0.001$ & & $<0.001$ & $<0.001$ & $<0.001$ & $<0.001$ \\
\hline Apr & & & $<0.001$ & $<0.001$ & $<0.001$ & $<0.001$ & $<0.001$ & $<0.001$ \\
\hline May & & & $<0.001$ & $<0.001$ & $<0.001$ & $<0.001$ & $<0.001$ & $<0.001$ \\
\hline Jun & & & $<0.001$ & & $<0.001$ & $<0.001$ & $<0.001$ & \\
\hline Aug & & & & & & $<0.001$ & & \\
\hline Oct & & & & & & & & $<0.001$ \\
\hline
\end{tabular}




\section{Sediment rating curves and yield}

Sediment rating curves generated using Method 4 (Table 2.2) resulted in coefficient of determination $\left(R^{2}\right)$ values ranging from 0.43 to 0.68 with a five-site average of 0.52. The five-site average observed log space correlation between discharge and SS concentrations met the satisfactory threshold $\left(R^{2}>0.5\right)$ suggested by Quilbe et al., (2006). Thus, the sediment rating curves provided in Table 2.6 were deemed useful for estimating sediment load and yield in the current study. These rating curves may also be useful tools for SS predictions in watersheds with similar climate, slope, roughness, soils, karst influence, vegetation, and land use practices.

Table 2.6. Parameters of log space discharge-concentration regression equations (sediment rating curves) generated using input data (daily average discharge) collected during 2010 - 2013 at five gauging sites in Hinkson Creek Watershed, Missouri, USA.

\begin{tabular}{cccc}
\hline Site \# & $\mathrm{b}_{0}$ & $\mathrm{~b}_{1}$ & $\mathrm{r}^{2}$ \\
\hline Site \#1 & -0.0540 & 0.5375 & 0.45 \\
Site \#2 & -1.3914 & 0.9651 & 0.43 \\
Site \#3 & -1.1796 & 0.8565 & 0.68 \\
Site \#4 & -0.4781 & 0.5498 & 0.52 \\
Site \#5 & -0.8056 & 0.6806 & 0.52 \\
\hline
\end{tabular}

Method 3 resulted in significantly lesser estimates of sediment yield relative to the other three methods tested $(p<0.022)$. Differences in median sediment yields ranged from $85.9 \mathrm{t} \mathrm{km}^{-2} \mathrm{yr}^{-1}$ between Methods 3 and 4 , to $120.6 \mathrm{t} \mathrm{km}^{-2} \mathrm{yr}^{-1}$ between Methods 3 and 2 . Conversely, estimates generated from Methods 1, 2, and 4 were not significantly different $(p>0.105)$. Method 4 showed the greatest amount of variability between sites with a fivesite mean of $101.5 \mathrm{t} \mathrm{km}^{-2} \mathrm{yr}^{-1}\left(S D=68.0 \mathrm{t} \mathrm{km}^{-2} \mathrm{yr}^{-1}\right)$, and therefore, was not chosen as the best method to accurately estimate sediment yield. Methods 1 and 2 showed less variability between site averages with a five-site means of $101.1 \mathrm{t} \mathrm{km}^{-2} \mathrm{yr}^{-1}(S D=16.1 \mathrm{t}$ 
$\left.\mathrm{km}^{-2} \mathrm{yr}^{-1}\right)$, and $127.2 \mathrm{t} \mathrm{km}^{-2} \mathrm{yr}^{-1}\left(S D=20.4 \mathrm{t} \mathrm{km}^{-2} \mathrm{yr}^{-1}\right)$. Thus, Methods 1 (linear

interpolation), and 2 (average sample load) resulted in the most accurate estimates of sediment yield of the four methods used in the current study (Table 2.7). Ultimately, Method 1 was presumably the most effective because the sampling regimen (4 sample days a week) captured the majority of the variability of discharge over the period of study (4 years) and therefore resulted in accurate estimates of actual pollutant loads.

Table 2.7. Comparisons of results using four methods used to estimate annual sediment loads $\left(\mathrm{t} \mathrm{yr}^{-1}\right)$ and yields $\left(\mathrm{t} \mathrm{km}^{-2} \mathrm{yr}^{-1}\right)$ from Hinkson Creek Watershed $\left(230 \mathrm{~km}^{2}\right.$ drainage area) located in central Missouri, USA. Method 1 is linear interpolation, Method 2 is average sample load, Method 3 is average sample concentration times average sample discharge, and Method 4 is log space discharge-concentration regression.

\begin{tabular}{cccccc}
\hline Element & Site \# & Method 1 & Method 2 & Method 3 & Method 4 \\
\hline Sediment & 1 & 7766.0 & 10227.5 & 649.0 & 3496.1 \\
Load & 2 & 10446.5 & 13144.3 & 816.4 & 18230.3 \\
$\left(\mathrm{t} \mathrm{yr}^{-1}\right)$ & 3 & 13541.1 & 17487.8 & 1187.7 & 18243.7 \\
& 4 & 13491.9 & 17433.2 & 1702.1 & 4708.2 \\
& 5 & 22136.2 & 25248.4 & 3568.9 & 19658.4 \\
\hline Sediment & 1 & 100.9 & 132.8 & 8.4 & 45.4 \\
Yield $^{-1}$ & 2 & 103.4 & 130.1 & 8.1 & 180.5 \\
$\left(\mathrm{t} \mathrm{km}^{-2} \mathrm{yr}^{-1}\right)$ & 3 & 118.8 & 153.4 & 10.4 & 160.0 \\
& 4 & 75.0 & 96.9 & 9.5 & 26.2 \\
& 5 & 107.5 & 122.6 & 17.3 & 95.4 \\
\hline
\end{tabular}

Using Method 1, observed sediment load from the HCW $\left(230 \mathrm{~km}^{2}\right)$ ranged from 5,184 $\mathrm{t} \mathrm{yr}^{-1}$ during 2012 to $61,044 \mathrm{t} \mathrm{yr}^{-1}$ during 2010 at Site \#5 (Table 2.8). Sediment load was greater by $14,370.2 \mathrm{t} \mathrm{yr}^{-1}$ at Site \#Site \#5 (located near the watershed outlet) relative to Site \#Site \#1 (nested within the headwaters). Median annual sediment load was correlated with annual total precipitation and the relationship increased with drainage area. Power regression analysis results showed $R^{2}$ values ranged from 0.926 (Site \#Site 
\#1) to 0.999 (Site \#Site \#5). Power regression analysis resulted in coefficient of determination values greater than 0.910 for every year of the study period with the exception of $2013\left(R^{2}=0.739\right)$ when annual sediment load was approximately $2000 \mathrm{t} \mathrm{yr}^{-1}$ less at Site \#Site \#4 relative to Site \#Site \#3 indicating a sediment sink between Sites \#3 and \#4 during 2013.

Sediment yield $\left(\mathrm{t} \mathrm{km}^{-2} \mathrm{yr}^{-1}\right)$ was calculated to quantify suspended sediment generated per unit area of land that drains to each monitoring site. The five-site study period average sediment yield was $101.1 \mathrm{t} \mathrm{km}^{-2} \mathrm{yr}^{-1}$. However, annual sediment yields ranged greatly from $16.1 \mathrm{t} \mathrm{km}^{-2} \mathrm{yr}^{-1}$ at Site \#Site \#2 during 2012, to $313.0 \mathrm{t} \mathrm{km}^{-2} \mathrm{yr}^{-1}$ at Site \#Site \#3 during 2010 consistent with differences in annual total precipitation (Table 2.8). The differences in annual median sediment yields were significantly greater ( $p<0.008$ ) during 2010 relative to 2011 and 2012. Significant differences in median annual sediment yields were also found between median sediment yields during 2013 and 2012. However, differences in annual sediment yields between sites were not significant $(p>0.05 ; n=5)$ at the $95 \%$ confidence level.

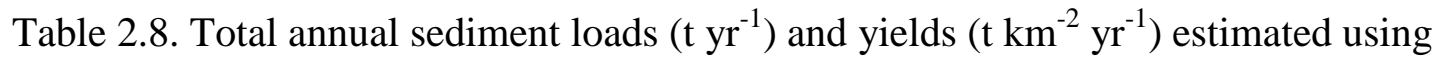
linear interpolation (Method 1) from 2010 - 2013 at five gauging sites in Hinkson Creek Watershed, Missouri, USA.

\begin{tabular}{lcccccc}
\hline Element & Date & Site \#1 & Site \#2 & Site \#3 & Site \#4 & Site \#5 \\
\hline Sediment & 2010 & 13825.1 & 23816.9 & 35687.7 & 51165.9 & 61044.7 \\
Load & 2011 & 3501.4 & 6058.3 & 6658.2 & 8678.4 & 14586.3 \\
$\left(\mathrm{t} \mathrm{yr}{ }^{-1}\right)$ & 2012 & 1262.7 & 1630.3 & 2513.2 & 3662.5 & 5184.8 \\
& 2013 & 12030.7 & 14834.7 & 20424.1 & 18305.3 & 29686.1 \\
\hline Sediment & 2010 & 179.5 & 235.8 & 313.0 & 284.3 & 296.3 \\
Yield & 2011 & 45.5 & 60.0 & 58.4 & 48.2 & 70.8 \\
$\left(\mathrm{t} \mathrm{km}^{-2} \mathrm{yr}^{-1}\right)$ & 2012 & 16.4 & 16.1 & 22.0 & 20.3 & 25.2 \\
& 2013 & 156.2 & 146.9 & 179.2 & 101.7 & 144.1 \\
\hline
\end{tabular}




\section{Discussion}

During the current study, average annual precipitation was approximately $91 \mathrm{~mm}$ less than the 20-year record (1992-2012) reported by Hubbart and Zell (2013). However, the study period consisted of extremely wet and dry years. For example, 2010 was a record wet year, while 2012 was a record dry year in the HCW. During 2012 extreme to exceptional (D3 to D4) drought conditions were observed in the region (NOAA, 2012). Hubbart and Zell (2013) reported average annual precipitation of $1082 \mathrm{~mm} \mathrm{yr}^{-1}$ (20-year record). Thus, precipitation during the study period ranged from approximately $400 \mathrm{~mm}$ drier to $250 \mathrm{~mm}$ wetter than the historic average for the region, which were ideal extreme conditions for the study. Precipitation was $3.3 \%$ greater in the urban area of the watershed. Hubbart et al., (2014) showed that differences in precipitation between urban and rural sites were not significant at the $95 \%$ confidence level in the HCW (Hubbart et al., 2014). However, given the differences observed in the current research, it is conceivable that urban heat island effects of the City of Columbia may impact the SS regime.

\section{Suspended sediment concentrations}

A change in sediment concentrations with stream distance and land use change was observed (Figure 2.2). Annual median sediment concentrations decreased by $60 \%$ from Site \#1 to Site \#Site \#3, and increased by $98 \%$ from Site \#Site \#3 to Site \#Site \#5 as agricultural land use decreased by $18.4 \%$ and urban land use increased by $21.6 \%$ from the headwaters (site 1) toward the watershed outlet (Site \#Site \#5) (Figure 2.3). Maximum suspended sediment concentrations were 30 to $61 \%$ greater at Sites \#4 and \#5. These differences were likely attributed to stormwater runoff from impervious surfaces resulting 
in increased channel incision, thereby disturbing sediments formerly deposited in stream bed and banks (Bernhardt et al., 2008). Disturbed soils from construction sites can also be sources of legacy sediment pollution from urbanized catchments (Bernhardt et al., 2008). Legacy sediments are known to transport adsorbed heavy metals, and/or agricultural chemicals that are potentially harmful to aquatic and human health (Bilotta and Brazier, 2008). Huang (2012) showed that streambank erosion contributed up to $67 \%$ of SS in Hinkson Creek during WY 2011. These results indicate a need for future investigations designed to identify the various toxins in legacy sediments of the study catchment and other urbanized agricultural watersheds in the region.

Walsh et al., (2005) associated urban land use with increased channel width, pool depth, and scouring linked to increased sediment supply and sedimentation. Other researchers corroborated this observation (e.g. MacRae and Rowney, 1992). Additionally, increased impervious surfaces have been associated with more frequent, increased velocities and runoff volume capable of incising stream channels and banks (Walsh et al., 2005). More frequent runoff events transport a greater amount of sediment over long time periods than infrequent catastrophic events (Leopold et al., 1964; MacRae and Rowney, 1992). There is thus a need for best management practices (BMPs) designed to reduce channel incision and mass wasting in order to conserve valuable floodplain lands and water quality. Results from the current, and previous work (Hubbart et al., 2013; Huang, 2012; Hubbart and Gebo, 2010) indicate a need for BMPs (e.g. bank stabilization) in the lower reaches of Hinkson Creek and similar urbanized drainages to reduce elevated SS concentrations. 


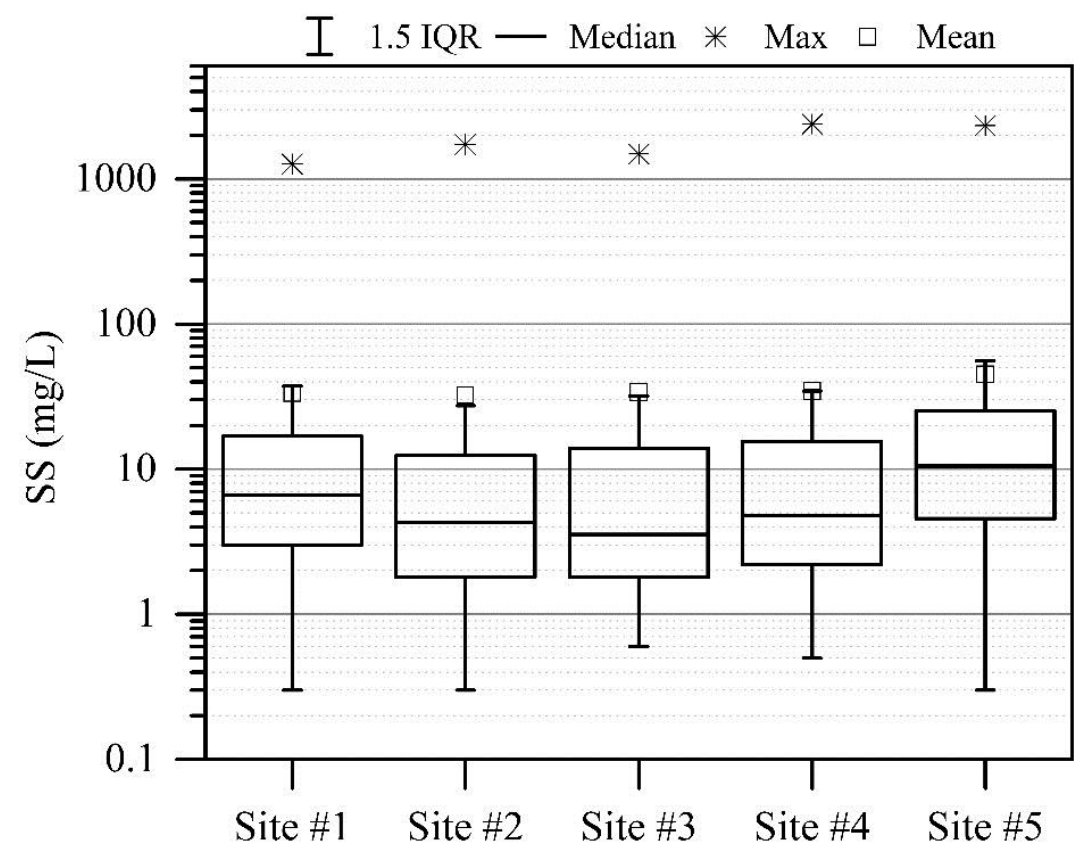

Figure 2.2. Suspended sediment (SS) concentration descriptive plots ( $n=836$ ) from 2010 -2013 at five gauging sites measured in Hinkson Creek, Missouri, USA. IQR is interquartile range. 

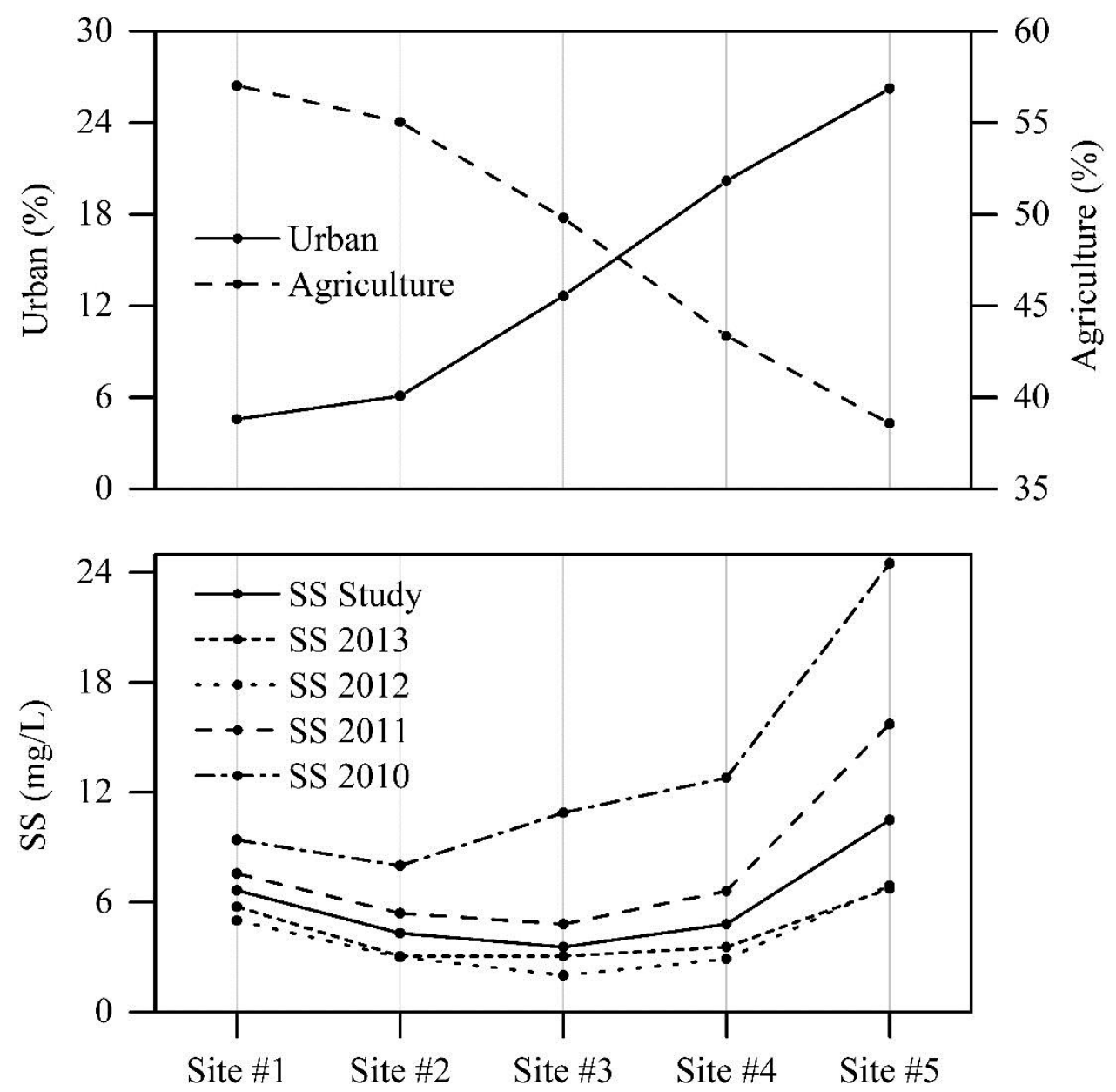

Figure 2.3. The change in the cumulative percent agriculture to urban land use with downstream distance from Site \#Site \#1 to \#5 (top). Annual median suspended sediment (SS) concentration ( $n=836$ ) from 2010 - 2013 at five gauging sites (bottom) located in Hinkson Creek, Missouri, USA.

Observed SS concentrations were greater in $\mathrm{HCW}$ relative to other watersheds in the Upper Mississippi River Basin (UMRB). Hinkson creek watershed borders the South Fork Salt Watershed in the UMRB. Estimated FWC's from South Fork Salt watershed were reported to be in the greatest range of median annual volumetrically weighted SS concentrations (263 to 9,300 $\mathrm{mg} \mathrm{L}^{-1}$ ) reported by USGS (2006). Median annual FWC's of $272.0 \mathrm{mg} \mathrm{L}^{-1}$ from HCW observed during the study period also fall into that range.

However, the median annual SS concentrations in the current work $\left(10.5 \mathrm{mg} \mathrm{L}^{-1}\right)$ fall into 
the $2^{\text {nd }}$ least bin of median SS concentrations, while estimated median annual SS concentrations from South Fork Salt watershed were reported to be in the greatest range of median annual volumetrically weighted SS concentrations $\left(65.1\right.$ to 7,600 $\left.\mathrm{mg} \mathrm{L}^{-1}\right)$ in the UMRB reported by USGS (2006). These differences are likely at least in part attributable to the differences in sampling resolution between the two studies. Suspended sediment samples were collected once mid-month in South Fork Salt Watershed for the USGS study, whereas samples were collected every other day in this study.

In comparison to FWC's from other watersheds in Missouri River Basin, the FWC's estimated in the current study were within the range for major tributaries of the Missouri River basin reported by Heimann et al., 2011 (65.9 to 5,160 $\left.\mathrm{mg} \mathrm{L}^{-1}\right)$. However, some of the tributaries have dams that likely attenuate SS yields. For example, median annual FWC's were $122 \%$ greater in HCW relative to a major tributary (the Osage River) of the Missouri River that is dammed (Hinkson Creek, $\mathrm{FWC}=272.0 \mathrm{mg} \mathrm{L}^{-1}$; Osage River, FWC $=66.8 \mathrm{mg} \mathrm{L}^{-1}$ ), while at the same time being 165 and $148 \%$ lesser than FWC's from the two closest major tributaries of Missouri River that are not dammed (Grand River, $\mathrm{FWC}=2820 \mathrm{mg} \mathrm{L}^{-1}$; Chariton River, $\mathrm{FWC}=1820 \mathrm{mg} \mathrm{L}^{-1}$ ). Gasconade River a major tributary of Missouri River is not dammed and median annual FWC's were $121 \%$ greater in $\mathrm{HCW}$ relative to Gasconade River ( $\mathrm{FWC}=65.6 \mathrm{mg} \mathrm{L}^{-1}$ ). In Missouri, sediment supply is generally lesser from Missouri River tributaries south of the Missouri River relative to tributaries to the north mainly due to differences in geology and soils between two Level I terrestrial Ecoregions, the Great Plains and Eastern Temperate Forests, the borders of which divide HCW between Sites \#2 and \#3. This information could be used to explain the differences in sediment supply transported from the Grand River and Chariton River 
watersheds as those watersheds are completely encompassed by the Great Plains ecoregion where sediment trapping dams are absent, and where soils in the Great Plain Ecoregion may be more erodible than soils in the Eastern Temperate Forests Ecoregion. Differences in ecoregions between the sites may be used to explain why land use was not strongly correlated to SS concentrations between each site.

The seasonal differences in FWC's were significantly greater $(p<0.001)$ during the wet season ( $2^{\text {nd }}$ quarter) relative to other seasons, particularly during April and May (Figure 2.4). For example, maximum SS concentrations exceeded 2,300 $\mathrm{mg} \mathrm{L}^{-1}$ at Sites \#4 and \#5 when $77.5 \mathrm{~mm}$ of total precipitation fell on April $24^{\text {th }}, 2010$ resulting in peak streamflow of $325.7 \mathrm{~m}^{3} \mathrm{~s}^{-1}$ at Site \#Site \#4. Maximum SS were 30 to $61 \%$ greater at Sites \#4 and \#5 relative to the other gauging sites likely due to stream bank mass wasting and incising of alluvial channels downstream of urban areas. The FWC's were also greater during December when snowmelt events contributed to streamflow. For example, SS concentrations ranged from $844 \mathrm{mg} \mathrm{L}^{-1}$ at Site \#Site \#4 to $1240 \mathrm{mg} \mathrm{L}^{-1}$ at Site \#Site \#1 when a rain on snow event $(4.0 \mathrm{~cm}$ of rainfall five days after $12.7 \mathrm{~cm}$ of snowfall) resulted in peak streamflow of $62.0 \mathrm{~m}^{3} \mathrm{~s}^{-1}$ at Site \#Site \#4 on December 31, 2010. Freezethaw conditions likely contributed to the increased SS on that day when SS concentrations were 22 to $38 \%$ greater at Sites \#1 and \#2 relative to the other monitoring sites. Ferrick and Gatto (2004) used a novel laboratory experimental design to show significant effects of soil freeze-thaw (FT) processes on upland hillslope erosion during runoff events that follow thaw. Sediment load increased with slope and discharge in both the FT and the control (C) treatments. However, only soil moisture increased sediment load in the FT treatment compared to a C soil treatment. Ferrick and Gatto (2004) showed 
FT/C ratios of $2.4(\mathrm{VWC}=16-18 \%$ ), and 5.0 (VWC=37-40\%). These results may be beneficial when planning the timing of soil conservation efforts in $\mathrm{HCW}$ and other watersheds where freeze-thaw conditions may increase erosion.

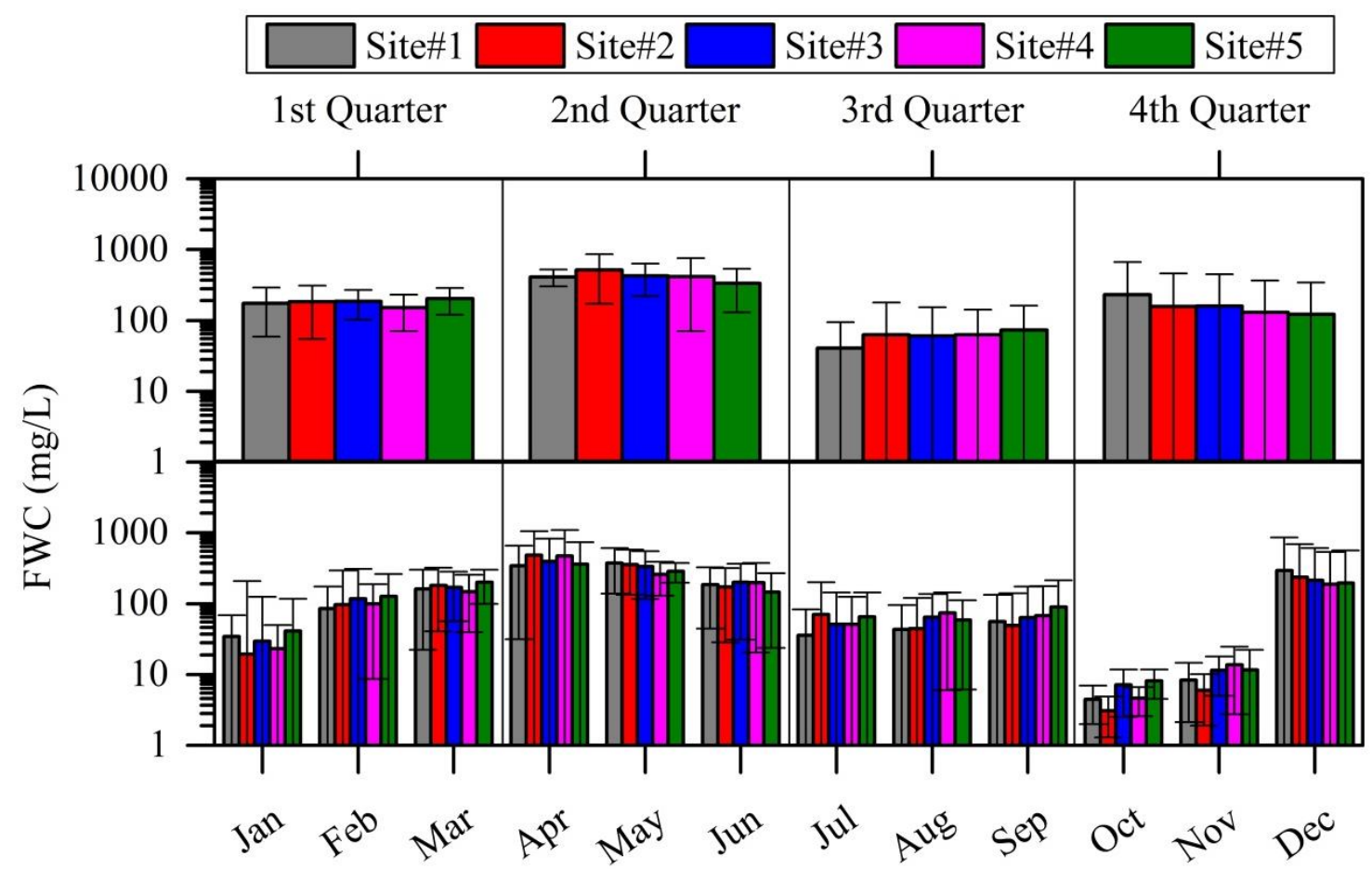

Figure 2.4. Average seasonal and monthly flow weighted mean sediment concentrations (FWC) for each site from 2010 - 2013 measured in Hinkson Creek, Missouri, USA. Error bars show one standard deviation between averages $(n=4)$.

\section{Sediment rating curves and yield}

Linear interpolation resulted in the most accurate SS load estimates of the four methods used. The success of Method 1 was attributed to the sampling interval of the observed data ( $n=836$ sampling days per site) that captured the variability in sediment concentrations with streamflow during the four year study. Method 1 is also the most direct method to estimate sediment load. However, practitioners should be cautious using this method since sediment loads can be underestimated when the sampling interval does 
not capture variability of discharge (Quilbe et al., 2006). While Method 3 has been shown to result in reliable estimates of sediment loading for comparison of relative ranking in sediment loading in other studies (Walling and Webb, 1981; Letcher et al., 1999), Method 3 resulted in significantly lesser estimates of loading relative to the other methods tested in the current research (Figure 2.5). The lack of precision of Method 3 was presumably due to bias of samples collected during low flows. In contrast, Method 2 resulted in a more accurate, flow-weighted estimate of sediment load. Method 4 resulted in greatly variable results between sites. The sediment rating curves in Table 2.4 may be useful in $\mathrm{HCW}$ or elsewhere in the region when estimates of SS concentrations are needed for land management decisions. Accuracy of the rating curves may be affected by land use change, and changes in soil conservation practices. Ultimately, caution should be exercised when relying on rating curve output in watersheds with differences in slope, roughness, soils, karst influence, vegetation, and/or land use practices.

Loading estimates generated using Method 1 resulted in median annual sediment yields that were greatest at Site \#Site \#3 with percent differences ranging from $10 \%$ (between Sites \#3 and \#5) to 45\% (between Sites \#3 and \#4). The decrease in sediment yield could be explained by the large increase (44\%) in drainage area between Sites \#3 and \#4 (Figure 2.1) because sediment yields are estimated per unit area basis $\left(\mathrm{t} \mathrm{km}^{-2} \mathrm{yr}^{-1}\right)$.

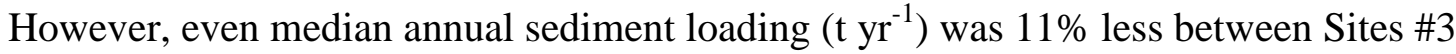
and \#4 during 2013 (Figure 2.6) indicating a sediment sink between Sites \#3 and \#4. This was surprising given the strong power relationship between annual sediment load and drainage area that indicated an increase in sediment load as drainage area increased. The observed data indicate that sediments built-up in the system during 2012 (year of 
drought) flushed through Sites \#1, \#2, and \#3, then deposited at some sediment sink between Sites \#3 and \#4 during 2013. This observation would be consistent with those of Hubbart and Gebo (2010) who referenced a punctuated equilibrium of sediment suspension and deposition in the HCW. Sediment load was above the precipitationsediment load power regression curve at sites\#1, \#2, and \#3 by 50\%, 28\%, and 24\%, respectively, during 2013. The buildup and washoff phenomenon of nonpoint-source pollutants has been observed in previous studies of urban catchments (Brezonik and Stadelmann, 2002). Pollutants have also been shown to buildup on roads during dry periods and wash off with large rainfall-runoff events (Eyles and Meriano, 2010). Results from the current work indicate that buildup and washoff effects may be a source of uncertainty for the sediment load power regression models dependent solely on precipitation, or drainage area.

Median annual sediment yields were 173\% greater during 2010 relative to 2012 mainly due to a difference of approximately $700 \mathrm{~mm}$ annual total precipitation. Other research showed a positive relationship between impervious surface coverage (ISC) and sediment yields (Nelson and Booth, 2002; Taylor and Owens, 2009), particularly residential urban land use in the riparian zone (Silva and Williams, 2001). For example, Nelson and Booth (2002) showed watershed urbanization accompanied by large increases in low-to-mid intensity urban land use accounted for $20 \%$ of the total sediment budget primarily through increased channel erosion and discharge in a mixed land use watershed of King County, Washington. Another study in a watershed near the HCW (Goodwater Creek Experimental Watershed) by Lerch et al., (2015b) showed claypan soils are related 
to increased runoff and erosion rates. Such information may be used to help explain large sediment yields of the HCW.

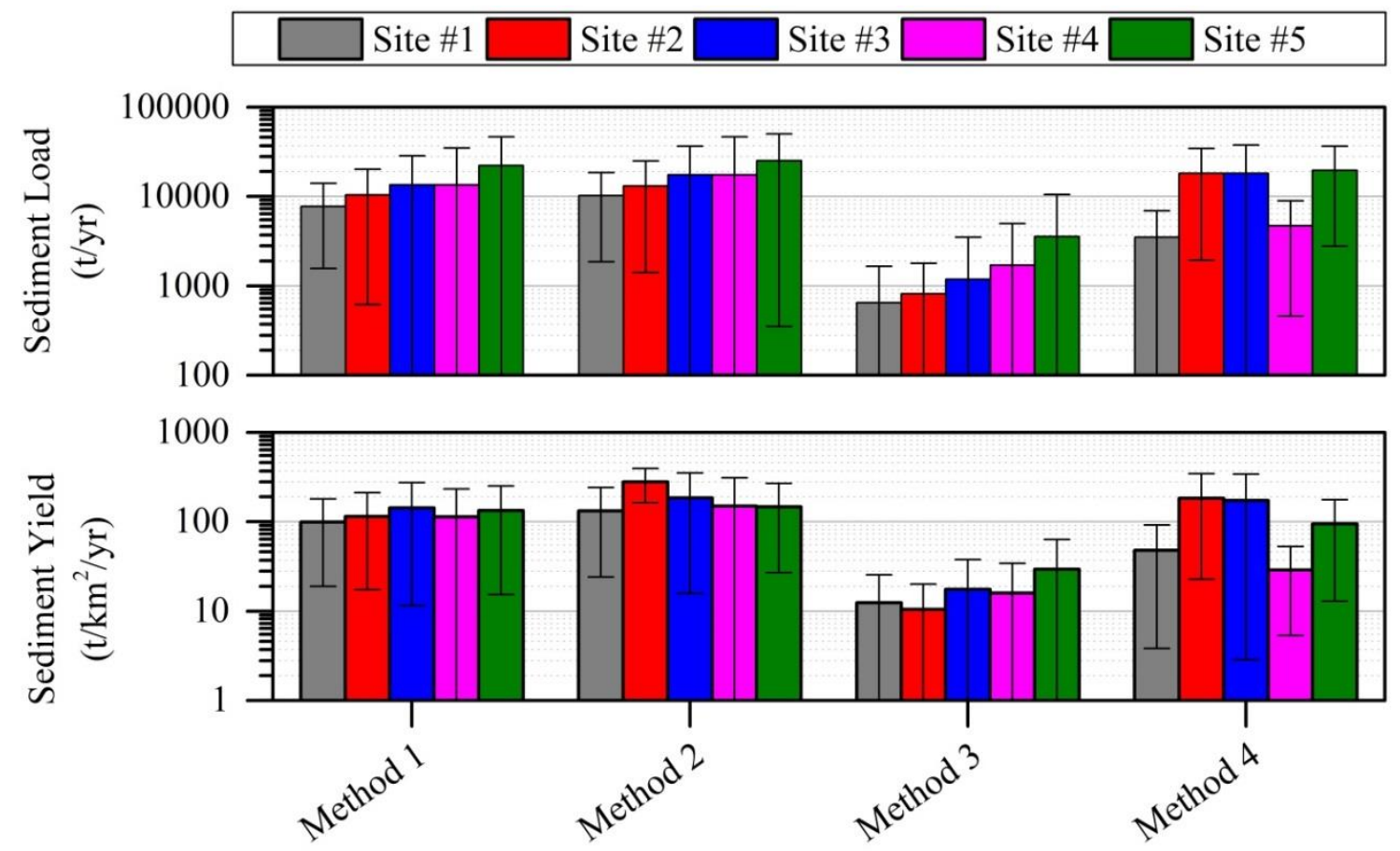

Figure 2.5. Comparisons of results using four methods used to estimate average annual sediment loading $\left(\mathrm{t} \mathrm{yr}^{-1}\right)$ and yields $\left(\mathrm{t} \mathrm{km}^{-2} \mathrm{yr}^{-1}\right)$ in Hinkson Creek Watershed, Missouri, USA. Method 1 is linear interpolation, Method 2 is average sample load, Method 3 is average sample concentration times average sample discharge, and Method 4 is log space discharge-concentration regression. Error bars show one standard deviation between averages $(n=4)$. 


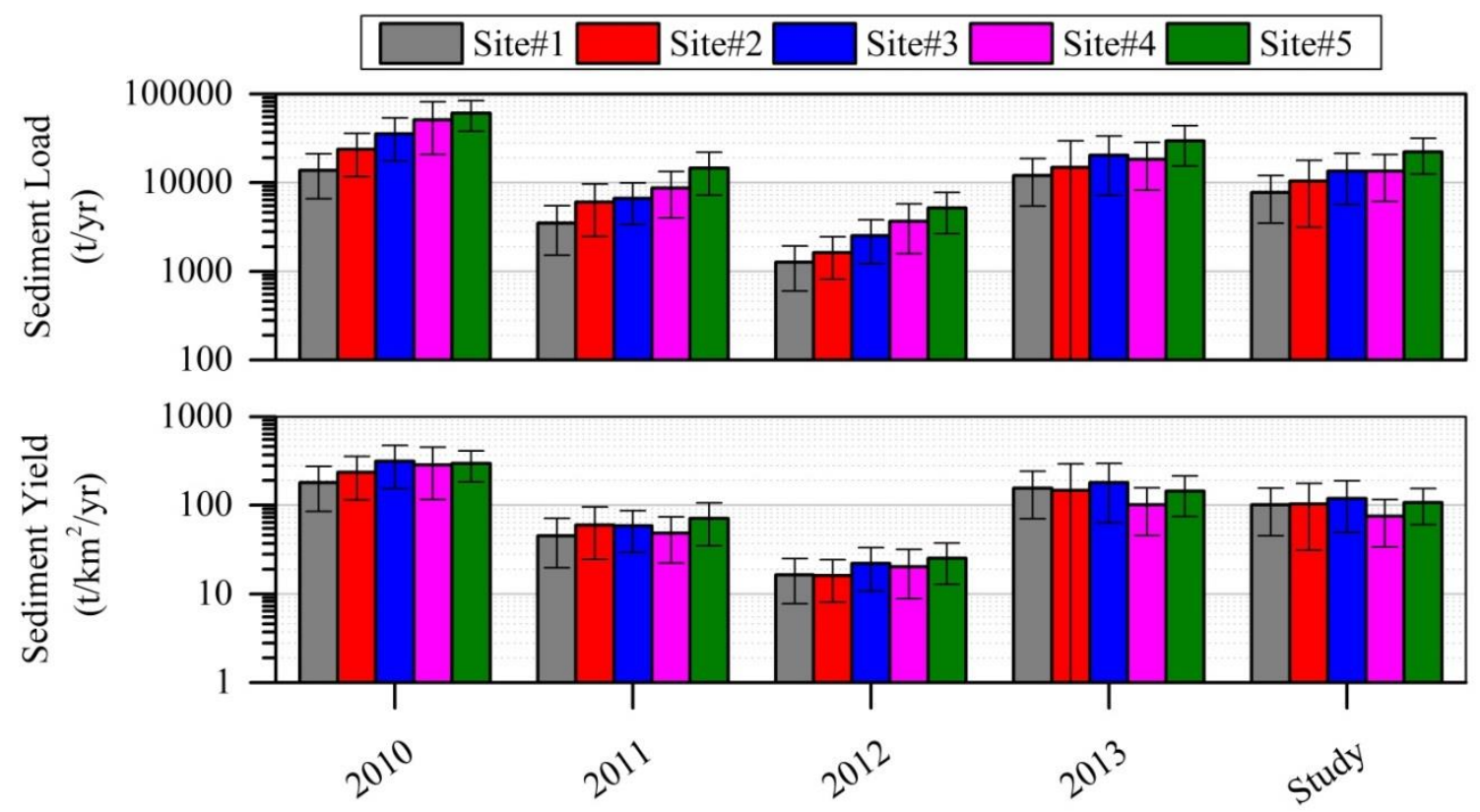

Figure 2.6. Annual sediment loads and yields estimated using linear interpolation (Method 1) from 2010 - 2013 at five nested-scale monitoring sites in Hinkson Creek Watershed, Missouri, USA. Study is the four year average. Error bars show the standard deviation of Methods 1 (linear interpolation), 2 (average sample load), 3 (average sample load times average sample discharge), and 4 (log space discharge-concentration regression).

\section{Study implications}

The HCW nested-scale experimental watershed study has served as a laboratory for the study of the effects of mixed-land use on water quantity and quality, and as a model for managers that need to target nonpoint-source pollution in similar mixed-landuse watersheds globally. Information from this research further advances previous understanding through a focused study on suspended sediment pollution from multiple land uses and critical source areas. Management efforts should focus on conserving soil resources in row crop and newly developing residential land use areas. This work emphasizes the urgent need to mitigate channel incision and bank losses in mixed-land use, urbanizing watersheds. 


\section{Conclusions}

The nested-scale experimental watershed study approach applied in this study made possible the observation of the change in suspended sediment concentrations with stream distance and land use change. Agricultural land use decreased by $18.4 \%$ while urban land use increased by $21.6 \%$ from headwaters to the watershed outlet. Annual median observed SS concentrations decreased by $60 \%\left(-0.25 \mathrm{mg} \mathrm{L}^{-1} \mathrm{~km}^{-1}\right)$ with downstream distance from the agricultural to the suburban monitoring site. Suspended sediment concentrations increased by $98 \%\left(0.4 \mathrm{mg} \mathrm{L}^{-1} \mathrm{~km}^{-1}\right)$ from the suburban to the urban monitoring site as urban land use increased by $13.5 \%$. The increase in sediment concentrations between the suburban and urban sites was likely due to the effects of urban land use and stormwater runoff. Maximum observed SS concentrations exceeded 2,300 $\mathrm{mg} \mathrm{L}^{-1}$ at urban sites\#4 and \#5. At greater temporal resolutions, seasonal average flow weighted concentrations (FWC's) were significantly lesser during the $3^{\text {rd }}$ quarter (July through September) $(p<0.007)$ with differences ranging from $99.4 \mathrm{mg} \mathrm{L}^{-1}$ during the $3 \mathrm{rd}$ and 4 th quarters of the year, to $359.8 \mathrm{mg} \mathrm{L}^{-1}$ during the $2^{\text {nd }}$ and $3^{\text {rd }}$ quarters. FWC's were greatest during the $2^{\text {nd }}$ quarter (April through June) corresponding to the normal wet season in the central USA. Additionally, monthly average FWC's were greatest during the wettest months of the year (April and May).

Sediment yields ranged from $25.2 \mathrm{t} \mathrm{km}^{-2} \mathrm{yr}^{-1}$ during 2012, to $296.3 \mathrm{t} \mathrm{km}^{-2} \mathrm{yr}^{-1}$ during 2010 at Site \#5 near the watershed outlet. Maximum sediment yield exceeded 300 $\mathrm{t} \mathrm{km}^{-2} \mathrm{yr}^{-1}$ at Site \#Site \#3 during 2010. Overall, sediment yields were 54\%, 80\%, and 87\% greater than sediment yields from the Ohio River, the Upper Mississippi River, and the Missouri River basins, respectively. The relatively large sediment yields were likely 
attributable to increased runoff rates from claypan soils in the headwaters, agricultural land use, and impervious surfaces. Increases in runoff volume and velocity and subsequent channel incision and bank erosion are well documented sources of suspended sediment pollution and need to be addressed to conserve valuable water resources. This research resulted in critically needed estimates of sediment yields at multiple spatial scales in a typical urbanizing catchment of the central USA. The study design used in this investigation may serve as useful model for managers that need to target non-point source pollutants in similar mixed-land-use watersheds globally.

\section{Acknowledgements}

Funding was provided by the Missouri Department of Conservation. Results presented may not reflect the views of the sponsors and no official endorsement should be inferred. Collaborators include (but are not limited to) Boone County Public Works, City of Columbia, University of Missouri, the Missouri Department of Natural Resources, and the U.S. Geological Survey. Special thanks are due to scientists of the Interdisciplinary Hydrology Laboratory, and constructive comments of multiple reviewers that improved the article. 


\section{Literature Cited}

American Society for Testing and Materials (ASTM). 2007. D 3977 - 97 Standard Methods for Determining Sediment Concentrations in Water Samples.

Arnold JG, Allen PM. 1999. Automated methods for estimating base flow and ground water recharge from streamflow records. JAWRA, 35(3): 411-424.

Bernhardt ES, Band LE, Walsh CJ, Berke PE. 2008. Understanding, managing, and minimizing urban impacts on surface water loading. Annals of the New York Academy of Sciences, 1134: 61-96.

Bilotta GS, Brazier RE. 2008. Understanding the influence of suspended solids on water quality and aquatic biota. Water Research, 42: 2849-2861.

Brezonik LP. 2002. Analysis and predictive models of stormwater runoff volumes, loads, and pollution concentration from watersheds in the Twins Cities metropolitan area, Minnesota, USA. Water Research, 36: 1742-1757.

Chang C-H, Wen C-G, Huang C-H, Chang S-P, Lee C-S. 2008. Nonpoint source pollution loading from an undistributed tropic forest area. Environ Monit Assess, 146:113-126.

Cheviron B, Delmas M, Cerdan O, Mouchel J.-M. 2014. Calculation of river sediment fluxes from uncertain and infrequent measurements. Journal of Hydrology, 508: 364-373.

Chin A. 2006. Urban transformation of river landscapes in a global context. Geomorphology, 79: 460-487.

Clark GM, Gregory M, David K, Mueller DK, and Mast MA. 2000. Nutrient concentrations and yields in undeveloped stream basins of the United States. JAWRA, 36(4): 849-860.

Dodds WK, Bouska WW, Eitzmann JL, Pilger TJ, Pits KL, Riley AJ, Schloesser JT, Thornbrugh DJ. 2009. Eutrophication of U.S. Freshwaters: Analysis of Potential Economic Damages. Environmental Science and Technology, 43(1): 12-19.

Dodds WK, Whiles MR. 2004. Quality and Quantity of Suspended Particles in Rivers: Continent-Scale Patterns in the United States. Environmental Management, 33(3): 355-367.

Eyles N, Meriano M. 2010. Road-impacted sediment and water in a Lake Ontario watershed and lagoon, City of Pickering, Ontario, Canada: An example of urban basin analysis. Sedimentary Geology, 224: 15-28. 
Ferrick MG, Gatto LW. 2004. Quantifying the effect of a freeze-thaw cycle on soil erosion: laboratory experiments. Earth Surf. Process. Landforms, 30: 1305-1326.

Heimann DC, Sprague LA, Blevins DW. 2011. Trends in Suspended-Sediment Loads and Concentrations in the Mississippi River Basin, 1950-2009. U.S. Geological Survey Scientific Investigations Report, 2011-5200, 33 p.

Hollister JW, August PV, Paul JF. 2008. Effects of spatial extent on landscape structure and sediment metal concentration relationships in small estuarine systems of the United States' Mid-Atlantic Coast. Landscape Ecology, 23: 91-106.

Huang D. 2012. Quantifying stream bank erosion and deposition rates in a central U.S. urban watershed. Master's thesis, University of Missouri, Columbia, Missouri.

Hubbart JA, and Zell C. 2013. Considering streamflow trend analyses uncertainty in urbanizing watersheds: a base flow case study in the central United States. Earth Interactions, 17(5): 1-28.

Hubbart JA, Gebo NA. 2010. Quantifying the effects of land-use and erosion by particle size class analysis in the central U.S. Erosion Control Journal, 17(7): 1-4.

Hubbart JA, Holmes J, Bowman G. 2010. Integrating science based decision making and TMDL allocations in urbanizing watersheds. The Watershed Science Bulletin, 01: 19-24.

Hubbart JA, Kellner E, Freeman G. 2013. A case study considering the comparability of mass and volumetric suspended sediment data. Environmental Earth Science, 71(9): 4051-4060.

Hubbart JA, Kellner E, Lynne H, Lupo AR, market PS, Guinan PE, Stephan K, Fox NI, Svoma, BM. 2014. Localized climate and surface energy flux alterations across an urban gradient in the central US. Energies, 7: 1770-1791.

Hubbart JA. 2011. Urban Floodplain Management. Stormwater, (September, 2011): 5663.

Jordan BA, Annable WK, Watson CC, Sen D. 2010. Contrasting stream stability characteristics in adjacent urban watersheds: Santa Clara Valley, California. River Res. Applic, 26: 1281-1297.

Kellner E, Hubbart JA, Thomas S. 2014. Quantifying urban land-use impacts on suspended sediment particle size class distribution. Stormwater, 15(2): 40.

Koirala AM. 2009. An Evaluation of Pre- and Post-Timber Harvest Water Quality in Low-Order Streams in the Missouri Ozarks. PhD Dissertation, Graduate School, University of Missouri-Columbia 
Kreutzweiser DP, Capell SS. 2001. Fine sediment deposition in streams after selective forest harvesting without riparian buffers. Can. J. For. Res., 31: 2134-2142.

Lamba J, Thompson AM, Karthikeyan KG, Fitzpatrick FA. 2015. Sources of fine sediment stored in agricultural lowland streams, Midwest, USA. Geomorphology, 236: 44-53.

Leopold LB, Wolman MG, Miller JP. 2012. Fluvial processes in geomorphology. Courier Corporation.

Lerch RN, Baffaut C, Kitchen NR, Sadler EJ. 2015b. Long-term agroecosystem research in the Central Mississippi River Basin: Dissolved nitrogen and phosphorus transport in a high-runoff-potential watershed. Journal of Environmental Quality, 44: 44-57.

Lerch RN, Kitchen NR, Baffaut C, Vories ED. 2015a. Long-term agroecosystem research in the Central Mississippi River Basin: Goodwater Creek Experimental Watershed and regional nutrient water quality data. Journal of Environmental Quality, 44: 37-43.

Letcher RA, Jakeman AJ, Merritt WS, McKee LJ, Eyre BD, Baginska B. 1999. Review of Techniques to Estimate Catchment Exports, Environment Protection Authority, Sydney.

Macrae CR, Rowney AC. 1992. The role of moderate flow events and bank structure in the determination of channel response to urbanization. Pages 12.1-12.21 in D. Shrubsole (editor). Resolving conflicts and uncertainty in water management. Canadian Water Resources Association, Kingston, Ontario.

Meybeck M, Laroche L, Durr HH, Syvitski JPM. 2003. Global variability of daily total suspended solids and their fluxes in rivers. Global and Planetary Change, 39: 6593.

Miller D, Vandike J. 1997. Groundwater resources of Missouri. Missouri Department of Natural Resources Division of Geology and Land Survey Water Resources Rep., 46., $136 \mathrm{pp}$.

Nelson EJ, Booth DB. 2002. Sediment sources in an urbanizing, mixed land-use watershed. Journal of Hydrology, 264: 51-68.

NOAA National Climatic Data Center, State of the Climate: Drought for Annual 2012, published online December 2012, retrieved on July 10, 2014 from http://www.ncdc.noaa.gov/sotc/drought/2012/13. 
Quilbe R, Rousseau AN, Duchemin M, Poulin A, Gangbazo G, Villeneuve JP. 2006. Selecting a calculation method to estimate sediment and nutrient loads in streams: application to the Beaurivage River (Quebec, Canada). Journal of Hydrology, 326(1-4): 295-310.

Rabotyagov SS, Klingy CL, Gassmanz PW, Rabalais NN, Turner RE. 2010. The Economics of Dead Zones: Causes, Impacts, Policy Challenges, and a Model of the Gulf of Mexico Hypoxic Zone. Review of Environmental Economics and Policy, 8(1): 58-79.

Schottler SP, Ulrich J, Belmont P, Moore R, Lauer JW, Engstrom DR, Almendinger JE. 2014. Twentieth century agricultural drainage creates more erosive rivers. Hydrological Processes, 28: 1951-1961.

Sliva L, Williams DD. 2001. Buffer zone versus whole catchment approaches to studying land use impact on river water quality. Water Research, 35: 3462-3472.

Taylor KG, Owens PN. 2009. Sediments in urban river basins: a review of sedimentcontaminant dynamics in an environmental system conditioned by human activities. J Soils Sediments, 9: 281-303.

Trimble S. 2009. Fluvial processes, morphology and sediment budgets in the Coon Creek Basin, WI, USA, 1975-1993. Geomorphology, 108: 8-23.

Turner RE, Rabalais NN. 2004. Suspended sediment, C, N, P, and Si yields from the Mississippi River Basin. Hydrobiologia, 511: 79-89.

Turner, R. E. \& N. N. Rabalais 2003. Linking landscape and water quality in the Mississippi River Basin. BioScience, 53: 563-572.

United States Census Bureau (USCB). 2014. U.S. Census Bureau: State and County Quick Facts. Available on line at: http://quickfacts.census.gov/qfd/states/29000.html

United States Geological Survey (USGS). 2006. Present and Reference Concentrations and Yields of Suspended Sediment in Streams in the Great Lakes Region and Adjacent Areas. Available on line at: http://pubs.usgs.gov/sir/2006/5066/

Walling D, Webb B. 1981. The reliability of suspended sediment load data. Erosion and Sediment Transport Measurement. IAHS Publication, 133: 177-194.

Walling DE. 2006. Human impact on land-ocean sediment transfer by the world's rivers. Geomorphology, 79: 192-216.

Walling DE. 2013. Changing fluvial sediment inputs to the world's deltas. Proceedings of HP1, IAHS-IAPSO-IASPEI Assembly, Gothenburg, Sweden, 358: 12-26. 
Walsh CJ, Roy AH, Feminella JW, Cottingham PD, Groffman PM, Morgan II RP. 2005. The urban stream syndrome: current knowledge and the search for a cure. Journal of the North American Benthological Society, 24(3): 706-723.

Zhou B, He HS, Nigh TA, Schulz JH. 2012. Mapping and analyzing change of impervious surface for two decades using multi-temporal Landsat imagery in Missouri. International Journal of Applied Earth Observation and Geoinformation, 18: 195-206. 


\title{
CHAPTER III
}

\section{NESTED-SCALE NUTRIENT YIELDS FROM A MIXED-LAND USE URBANIZING \\ WATERSHED}

In Print:

Zeiger, S., and J.A. Hubbart. 2015. Nested-Scale Nutrient Yields from a Mixed-Land Use Urbanizing Watershed. Hydrological Processes. DOI: 10.1002/hyp.10716

\begin{abstract}
To improve quantitative understanding of mixed-land-use impacts on nutrient yields, a nested-scale experimental watershed study design $(n=5)$ was applied in a 303(d), clean water act impaired urbanizing watershed of the lower Missouri River Basin, USA. From 2010-2013, water samples ( $n=858$ sample days per site) were analyzed for total inorganic nitrogen $(\mathrm{TIN}-\mathrm{N})$, nitrite $\left(\mathrm{NO}_{2}-\mathrm{N}\right)$ nitrate $\left(\mathrm{NO}_{3}-\mathrm{N}\right)$, ammonia $\left(\mathrm{NH}_{3}-\mathrm{N}\right)$, and total phosphorus (TP-P). Annual, seasonal, and monthly flow-weighted concentrations (FWCs) and nutrient yields were estimated. Mean nutrient concentrations were highest where agricultural land use comprised $58 \%$ of the drainage area $\left(\mathrm{NH}_{3}=0.111 \mathrm{mg} \mathrm{L}^{-1}\right.$; $\left.\mathrm{NO}_{2}=0.045 \mathrm{mg} \mathrm{L}^{-1} ; \mathrm{NO}_{3}=0.684 \mathrm{mg} \mathrm{L}^{-1}, \mathrm{TIN}=0.840 \mathrm{mg} \mathrm{L}^{-1} ; \mathrm{TP}=0.127 \mathrm{mg} \mathrm{L}^{-1}\right)$. Average TP-P increased by $15 \%$ with $20 \%$ increased urban land use area. Highly variable annual precipitation was observed during the study with highest nutrient yields during 2010 (record setting wet year) and lowest nutrient yields during 2012 (extreme drought year). Annual TIN-N and TP-P yields exceeded 10.3 and $2.04 \mathrm{~kg} \mathrm{ha}^{-1} \mathrm{yr}^{-1}$ from the agricultural dominated headwaters. Mean annual $\mathrm{NH}_{3}-\mathrm{N}, \mathrm{NO}_{2}-\mathrm{N}, \mathrm{NO}_{3}-\mathrm{N}$, TIN-N, and TP-P yields were $0.742,0.400,4.24,5.38$, and $0.979 \mathrm{~kg} \mathrm{ha}^{-1} \mathrm{yr}^{-1}$, respectively near the watershed
\end{abstract}


outlet. Precipitation accounted for the majority of the explained variance in nutrient yields $\left(R^{2}\right.$ values from 0.68 to 0.85$)$. Nutrient yields were also dependent on annual precipitation of the preceding year $\left(R^{2}\right.$ values from 0.87 to 0.91$)$ thus enforcing the great complexity of variable mixed-land-use mediated source-sink nutrient yield relationships. Study results better inform land managers and best management practices designed to mitigate nutrient pollution issues in mixed-land-use freshwater ecosystems.

\section{Introduction}

Anthropogenic inputs of nitrogen $(\mathrm{N})$ and phosphorus $(\mathrm{P})$ associated with agricultural and urban land uses are among the leading causes of water quality impairment in the United States (Howarth et al., 1996; Carpenter et al., 1998; Clark et al., 2000; Baffaut et al., 2009; Lerch et al., 2015a). In 1987, the National Water Quality Assessment (NAWQA) Program reported nitrogen fertilizer application rates greater than $2.5 \mathrm{t} \mathrm{km}^{-2} \mathrm{yr}^{-1}$ over a broad area of the upper Midwest in the Mississippi River Basin (MRB) (Mueller and Helsel, 2013). Increased nutrient loading associated with land use (including, but not limited to, agricultural and urban runoff) from the entire MRB has resulted in eutrophication of streams, lakes, and rivers, and contributed to the Hypoxic Zone (aka: the Dead Zone) in the Gulf of Mexico with $\mathrm{N}$ and $\mathrm{P}$ nutrient yields as large as 483 and $45 \mathrm{~kg} \mathrm{~km}^{-2} \mathrm{yr}^{-1}$, respectively (Clark et al., 2000; Battaglin et al., 2001; Rabalais et al., 2002; Turner and Rabalais, 2004; Alexander et al., 2008). Large scale environmental problems such as hypoxia in the Gulf of Mexico necessitate focused hydrologic monitoring of select inland terrestrial and stream ecosystems to improve quantitative understanding of anthropogenic impacts to nutrient loading (Hubbart et al., 2010; Birgand et al., 2007). 
Nutrient loading is greatly dependent on climate and related precipitation regimes (Kashaul et al., 2008), with nutrient retention and flushing periods corresponding to dry and wet periods. At shorter, event-based time scales, large precipitation/flow events can result in rapid mobilization and transport of nutrients to receiving water bodies. For example, Royer et al., (2006) showed that nearly all nitrate and dissolved reactive phosphorus were exported when discharge was above median flow values. Specifically, eighty percent of phosphorus and $50 \%$ of nitrate were exported when discharge was greater than the 90th percentile from the Embarras, Kaskaskia, and Sangamon watersheds in Illinois, USA. Results from Royer et al., (2006) and others (Letcher et al., 1999; Quilbe et al., 2006) clearly highlight the need for nutrient sampling regimens that capture the variability of climate and flow mediated nutrient transport and loading.

Urbanization can amplify the effects of climate variability and extreme climate on nutrient export. For example, similar to saturated soil conditions, impervious surfaces and conventional drainage systems reduce infiltration and shunt stormwater from the landscape, effectively bypassing riparian areas that often retain and attenuate nutrients (Groffman et al., 2004; Wollhiem et al., 2005; Kaushal et al., 2008). Shields et al., (2008) noted that in more developed areas (i.e. impervious areas $>15 \%$ ) the majority of nitrogen export occurs during high flow periods, whereas areas with little impervious surfaces (i.e. impervious areas $<1 \%$ ) are associated with nitrogen loading during base flow periods. This is an important observation since exported nutrients can cause multiple water quality problems in receiving water bodies including eutrophication. Excess nutrients that enter stream systems during base flow periods in urban areas are likely to cause localized eutrophication, particularly during summer months when water temperatures are warmer 
(Royer et al., 2006). Given that predicted future land use changes and climate trends may confound common assumptions about land-use, human population and nutrient transport combined processes (Palmer et al., 2008), there is a great need to study these relationships in mixed-land-use urbanizing watersheds (Kaushal et al., 2008).

Previous studies showed that mixed-land-use watersheds (i.e. blended combinations of land use practices) exhibit variously altered watershed hydrology and nutrient inputs relative to wild land or rural counterparts (Bolstad and Swank, 1997; Jordan et al., 1997; Salvia-Castellvi et al., 2005; Poor and McDonnel, 2007). For example, Poor and McDonnel (2007) explained that nitrate concentrations in urban watersheds variously mimic storm hydrographs in forested and residential catchments, thus mirroring altered residence times and flow paths consistent with both climate and land use practices. For example, Floyd et al., (2009) showed that nitrate concentrations were positively correlated to poorly drained soils $(r=0.63-0.87)$ and negatively correlated to woody vegetation ( $r=-0.81$ to -0.94$)$ at multiple spatial scales of stream buffers $(10$, $20,30,60,90,150,300 \mathrm{~m})$. Correlations were strongest between poorly drained soils and nitrate concentrations at the watershed scale thus illustrating the difficulty of disentangling climate and land use effects at the sub-basin level where best management practices are implemented. Investigations of the effects of land use on stream nutrient levels at multiple spatio-temporal scales remains a rich avenue for research due to the complex interactions with climate in mixed-land-use watersheds. Many authors have identified decoupling the effects of hydrology and land use as one of the greatest challenges of this century (Jordan et al., 1997; Salvia-Castellvi et al., 2005; Poor and McDonnel, 2007). Therefore, the objectives of this work were to a) investigate spatio- 
temporal nutrient concentration trends, b) quantify nutrient yields, and c) relate observed nutrient concentrations and yields to patterns of hydroclimate and land-use using four years of data (including record setting wet years and a year of extreme drought) collected in a contemporaneous mixed-land use urbanizing watershed using a nested-scale experimental watershed study design.

\section{Methods}

Study Area

The Hinkson Creek Watershed (HCW) is an urbanizing agricultural watershed of approximately $230 \mathrm{~km}^{2}$ located in central Missouri, USA (Figure 3.1). The headwaters of the watershed are dominated by agricultural land use including (but not limited to) pasture and row crops, which decrease as urban land use increases with stream distance (Table 3.1). The southern-most half of the HCW includes approximately $60 \%$ of the City of Columbia, Missouri (population 113,225; USCB, 2012). Approximately $28 \mathrm{~km}^{2}$ of impervious surface is located within Columbia's municipal boundary (Zhou et al., 2012). A 20-year climate record in the HCW (1992 to 2012) indicated average annual precipitation and temperature was $1082 \mathrm{~mm}$, and $14{ }^{\circ} \mathrm{C}$, respectively (Hubbart and Zell, 2013). Soils in the headwaters of HCW are dominated by loamy loess with an underlying claypan corresponding to the Mexico-Leonard association (Hubbart and Zell, 2013). Upland soils are a cherty clay solution residuum corresponding to the Weller-BardleyClinkenbeard (CBC) association (Hubbart and Zell, 2013). Claypan consists of an argillic soil horizon of smectitic mineralogy with clay content of $450-650 \mathrm{~g} \mathrm{~kg}^{-1}$ formed at 10 to $50 \mathrm{~cm}$ depth (Lerch et al., 2015b) and are characterized by increased surface runoff 
(Sadler et al., 2015) with base flow/surface flow ratios less than 0.25 (Baffaut et al., 2015).

The HCW contains a stream network ranging from 1st to 3rd order streams. Elevation ranges from 274 to $177 \mathrm{~m}$ above mean sea level (Hubbart et al., 2013). With a drainage distance of approximately 56 kilometers, Hinkson Creek, the main drainage of HCW, was placed on the Clean Water Act 303(d) list of impaired waters in 1998. The declared impairment at that time was protection of warm water aquatic life from unknown pollutants (MDNR 2006). The HCW was instrumented in 2009 with a nestedscale experimental watershed design (Figure 3.1) and partitioned into five subbasins, each with different dominant land use types (Hubbart et al., 2010). Site \#1 drains 78.9 $\mathrm{km}^{2}$ with 57\% agricultural and 5\% urban land uses, while Site \#Site \#5 drains $207.5 \mathrm{~km}^{2}$ with $39 \%$ agricultural and $26 \%$ urban land uses. Site $\# 4$ is complemented by a U.S. Geological Survey gauging station that has intermittently monitored stage since 1967. The need to quantify nutrient yields to better characterize possible pollutants, aquatic biological health status, and target mitigation strategies in the HCW was the impetus for this research. While regional in focus, the current work has global implications in that the $\mathrm{HCW}$ is a representative mixed-land use watershed exhibiting many land use characteristics ranging from forest to agriculture to urbanization, similar to many developing watersheds globally. 
Table 3.1. Cumulative stream length $(\mathrm{km})$, drainage area $\left(\mathrm{km}^{2}\right)$, and land use/land cover area $\left(\mathrm{km}^{2}\right)$ to each gauging site located in Hinkson Creek Watershed (HCW), Missouri, USA. Percentages of total drainage area are shown in parentheses.

\begin{tabular}{|c|c|c|c|c|c|c|}
\hline Site \# & $\begin{array}{l}\text { Stream } \\
\text { Length }\end{array}$ & Area & Urban & PasturelCrop & Forested & Wetland \\
\hline & $\mathrm{km}$ & \multicolumn{5}{|c|}{$\mathrm{km}^{2}$} \\
\hline 1 & 22.8 & 78.9 & $3.6(4.6)$ & $45(57.0)$ & $28.4(36.0)$ & $1.9(2.4)$ \\
\hline 2 & 29.8 & 102.8 & $6.3(6.1)$ & $56.6(55.1)$ & $37.5(36.5)$ & $2.4(2.3)$ \\
\hline 3 & 35.4 & 116.2 & $14.7(12.7)$ & $57.9(49.8)$ & $41.1(35.4)$ & $2.5(2.2)$ \\
\hline 4 & 43.6 & 182 & $36.7(20.2)$ & $78.9(43.4)$ & $62.8(34.5)$ & $3.6(2.0)$ \\
\hline 5 & 53.0 & 207.5 & $54.4(26.2)$ & $80.1(38.6)$ & $68.6(33.1)$ & $4.4(2.1)$ \\
\hline $\mathrm{HCW}$ & 56.0 & 232.9 & $67.3(28.9)$ & $85.8(36.8)$ & $74.9(32.2)$ & $4.9(2.1)$ \\
\hline
\end{tabular}
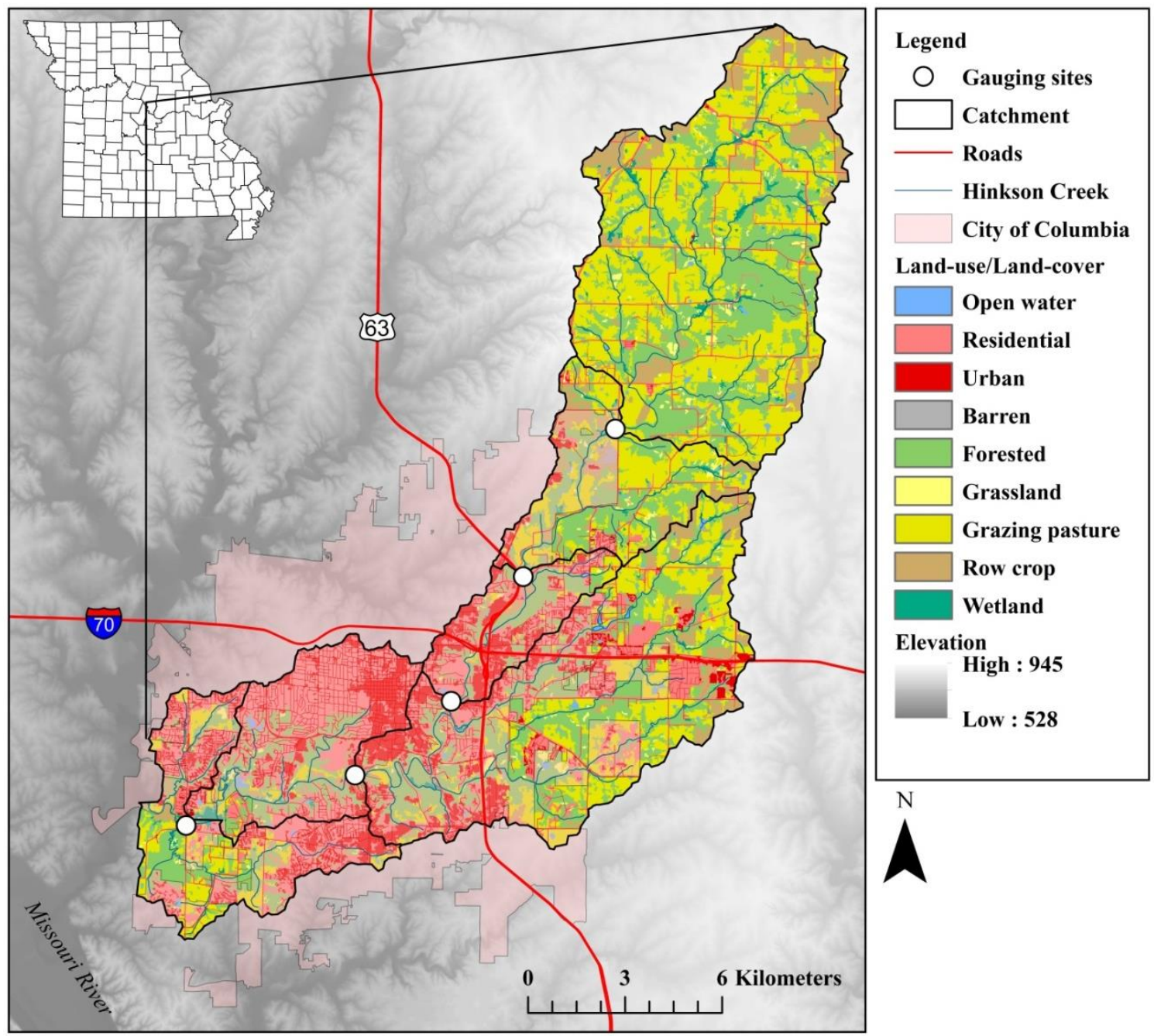

Figure 3.1. Nested-scale experimental watershed study design including five gauging sites located in Hinkson Creek Watershed, Missouri, USA. 


\section{Hydroclimate}

Previously installed hydroclimate stations $(n=5)$ were used to continuously monitor precipitation, stage, solar radiation, wind speed and direction, air and stream temperature and relative humidity (Hubbart et al., 2010). Stage-discharge rating curves were developed for each site to convert five minute stage $(\mathrm{m})$ to discharge $\left(\mathrm{m}^{3} \mathrm{~s}^{-1}\right.$; Hubbart et al., 2013). Data gaps in precipitation or stage less than one day were linearly interpolated when precipitation events did not occur. Any other data gaps in precipitation or stage were modeled using empirical techniques (i.e. regression, $R^{2}>0.90$ ) from complementary data collected at nearby gauging sites. Hydroclimate data from each site were reduced by averaging to daily time steps, and descriptive statistics were calculated for each year of the four year study period (2010 - 2013). Percent of base flow contributing to discharge was estimated using Equations (1) and (2), a base flow separation algorithm used by Arnold and Allen (1999):

$$
b_{t}=Q_{t}-q_{t}
$$

where $b_{t}$ is base flow at a daily time step,,$Q_{t}$ is stream flow and $q_{t}$ is filtered surface runoff at a daily time step. $q_{t}$ is calculated as follows:

$$
q_{t}=\beta q_{t-1}+\frac{1+\beta}{2} *\left(Q_{t}-Q_{t-1}\right)
$$

where 8 is a calibration parameter $(0.925)$.

\section{Observed nutrient concentrations}

Stream water grab samples were collected for four years (2010 - 2013) on Monday, Wednesday, Friday and Saturday at each nested monitoring site $(n=858$ sampling days per site; Figure 3.1). Water samples were placed on ice and analyses were conducted within 24 hours of collection. Analyses included ammonia $\left(\mathrm{NH}_{3}-\mathrm{N}\right)$, nitrite 
$\left(\mathrm{NO}_{2}-\mathrm{N}\right)$, nitrate $\left(\mathrm{NO}_{3}-\mathrm{N}\right)$, and total phosphorus $(\mathrm{TP})$ concentration using $\mathrm{HACH}$ TNTPlus $^{\mathrm{TM}}$ analytes. Total inorganic nitrogen (TIN) was estimated by summing $\mathrm{NH}_{3}-\mathrm{N}$, $\mathrm{NO}_{2}-\mathrm{N}$, and $\mathrm{NO}_{3}-\mathrm{N}$ concentrations Analyses were performed according to standard protocols using a HACH DR 2800 spectrophotometer (HACH Company, Loveland, CO). Tests for differences in observed nutrient concentrations were conducted between gauging sites using Kruskal-Wallis and Dunn's post-hoc multiple comparison tests ( $C I=95 \%, \alpha=0.05$; Lerch et al., 2015b). Regression techniques were used to test for significant relationships between observed nutrient concentrations and land use $(C I=95 \%, \alpha=0.05)$. Quality assurance (QA) protocols were conducted weekly with a $10 \%$ tolerance of error, and duplicates $(n=1260)$ that were collected on a monitoring site rotation Monday and Wednesday every week. Kruskal-Wallis tests showed no significant differences $(C I=95 \%, p>0.741, n=315)$ between samples and corresponding duplicates.

\section{Flow-weighted concentrations}

Flow-weighted mean nutrient concentrations [FWC; (Clark et al., 2000; Chang et al., 2008)] were calculated to remove bias possibly associated with differences in discharge and water sample timing over the period of averaging at monthly, seasonal (quarterly), and annual time steps to characterize nutrient concentration regimes at each site. Nutrient concentrations below the detection limit for each element tested $\left(\mathrm{NO}_{3}-\right.$ $\mathrm{N}=0.23 \mathrm{mg} \mathrm{L}^{-1}, \mathrm{NO}_{2}-\mathrm{N}=0.015 \mathrm{mg} \mathrm{L}^{-1}, \mathrm{NH}_{3}-\mathrm{N}=0.015 \mathrm{mg} \mathrm{L}^{-1}, \mathrm{TP}-\mathrm{P}=0.05 \mathrm{mg} \mathrm{L}^{-1}$ ) were included in the FWC calculations. Nutrient concentrations were linearly interpolated for un-sampled days to calculate FWC's with the following equation:

$$
F W C=\frac{\sum_{l}^{n}\left(c_{i} * t_{i} * q_{i}\right)}{\sum_{l}^{n}\left(t_{i} * q_{i}\right)}
$$


where $F W C$ is flow-weighted mean nutrient concentration, $c_{i}$ is concentration of the $i^{\text {th }}$ sample, $t_{i}$ is time interval for the $i^{t h}$ sample, $q_{i}$ is discharge for the $i^{\text {th }}$ sample.

Statistical tests for differences in FWCs between gauging sites included KruskalWallis and Dunn's post-hoc multiple comparison tests $(C I=95 \%, \alpha=0.05)$ (Lerch et al., 2015b). Regression was used to test for significant relationships between seasonal FWCs and hydroclimate variables $(C I=95 \%, \alpha=0.05)$.

\section{Nutrient yield}

While simple in concept, there is no universally agreed upon method to accurately estimate nutrient loading (Letcher et al., 1999; Quilbe et al., 2006). Therefore, it is often best practice to use multiple methods (Letcher et al., 1999). Thus, four methods were used to estimate nutrient load (i.e. yield) including linear interpolation, average sample load, average sample concentration times average sample discharge, and log space discharge-load regression (Letcher et al., 1999) (Table 3.2). The only difference between

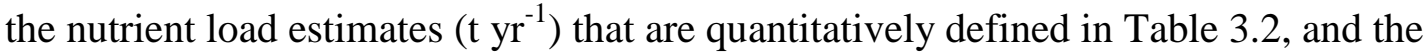
nutrient yield estimates $\left(\mathrm{t} \mathrm{ha}^{-1} \mathrm{yr}^{-1}\right)$ presented forthwith are units of estimation (i.e. nutrient yields are simply nutrient load estimates presented on a per unit area basis). Discharge data were averaged from 5-minute to hourly values for nutrient load calculations. Statistical tests to assess spatial and temporal differences in nutrient yields between gauging sites, included Kruskal-Wallis and Dunn's post-hoc multiple comparison tests $(C I=95 \%, \alpha=0.05)$ (Lerch et al., 2015b). Regression techniques were used to test for significant relationships between annual nutrient yields and hydroclimate variables $(C I=95 \%, \alpha=0.05)$ (Lerch et al., 2015b). 
Log space discharge-load regression relationships (rating curves; Letcher et al., 1999) were estimated to generate monthly and annual load estimates. Monthly nutrient load estimates were validated using observed data from 2013. Nash-Sutcliffe efficiency (NSE), ratio of root mean square error to the standard deviation of observed data (RSR), and percent bias (PBIAS) were calculated to access the accuracy of nutrient rating curve output (Moriasi et al., 2007).

Table 3.2. Four methods used to calculate nutrient load estimates. Concentration is $C, Q$ is discharge at the time of sampling, $t$ is time, $K$ is the time interval of load in seconds, $n$ is sample size, $b_{0}$ and $b_{1}$ are fitted regression parameters.

\begin{tabular}{lll}
\hline Method \# & Method description & Equation \\
\hline Method 1 & Linear Interpolation & $L_{1}=\sum_{i=1}^{n+1} \sum_{t_{i}<t \leq t_{i+1}}^{i} Q_{t}\left(\frac{C_{t_{i}}\left(t_{i+1}-t\right)+C_{t_{i+1}}\left(t-t_{i}\right)}{t_{i+1}-t}\right)$ \\
Method 2 & Average sample load & $L_{2}=K\left(\frac{1}{n} \sum_{i=1}^{n} C_{i} Q_{i}\right)$ \\
Method 3 & $\begin{array}{l}\text { Average sample } \\
\text { concentration x average } \\
\text { sample discharge }\end{array}$ & $L_{3}=K\left(\frac{1}{n} \sum_{i=1}^{n} C_{i}\right)\left(\frac{1}{n} \sum_{i=1}^{n} Q_{i}\right)$ \\
Method 4 & $\begin{array}{l}\text { Log space discharge- } \\
\text { load regression }\end{array}$ & $L_{4}=\sum_{i=1}^{365} Q_{i}\left[\exp \left(b_{0}+b_{1} \ln Q_{i}\right)\right]$ \\
\hline
\end{tabular}

\section{Results}

Hydroclimate

Average annual precipitation was approximately $991( \pm 300 \mathrm{~mm})$ during the fouryear study (2010 - 2013). The first year of the study period (2010) was the third consecutive record setting wet year with annual total precipitation ranging from $1310 \mathrm{~mm}$ at Site \#Site \#1 to $1342 \mathrm{~mm}$ at Site \#Site \#3 (Table 3.3). Conversely, 2012 was the driest year of the study with annual total precipitation ranging from $639 \mathrm{~mm}$ at Site \#Site \#2 to 
$696 \mathrm{~mm}$ at Site \#Site \#3. The differences in precipitation between Site \#Site \#3 and Site \#Site \#1 were outside the accuracy of the gauges during 2010 (-30.0 to $\left.9.0 \mathrm{~mm} \mathrm{yr}^{-1}\right)$ and thus assumed as indicative of previously identified precipitation heterogeneity in the watershed (Hubbart and Zell, 2013; Hubbart et al., 2014). Precipitation remained greater at Site \#Site \#3 compared to Sites \#1 and \#2 during the extreme drought year of 2012. Maximum daily total precipitation was $13 \mathrm{~cm}$ at Site \#Site \#5 during 2010. Considering the accuracy of the rain gauges (-9 to $6 \mathrm{~mm} \mathrm{yr}^{-1}$ during 2012), this work highlights probable precipitation heterogeneity in the HCW that may result in differential precipitation and land-use rainfall-runoff relationships. Daily median streamflow was more than $0.1 \mathrm{~m}^{3} \mathrm{~s}^{-1}$ from Site \#Site \#2 to Site \#Site \#5 throughout the study period (Table 3.3). Median streamflow was less than $0.1 \mathrm{~m}^{3} \mathrm{~s}^{-1}$ and thus typical of a Midwest USA ephemeral headwaters stream (Site \#Site \#1). Base flow separation analysis resulted in annual base flow indices $(\mathrm{BFI})$ of $0.17,0.20,0.20,0.25,0.27$ in order from Sites \#1 to \#5, respectively, indicating a relatively lesser base flow contribution to streamflow at Site \#Site \#1 in the headwater compared to downstream study sites. Daily maximum streamflow ranged by $13.0 \mathrm{~m}^{3} \mathrm{~s}^{-1}$ during 2012 to $58.0 \mathrm{~m}^{3} \mathrm{~s}^{-1}$ during 2013 at Site \#Site \#1. At the near terminus of the watershed (Site \#Site \#5), daily maximum streamflow ranged from $53.0 \mathrm{~m}^{3} \mathrm{~s}^{-1}$ during 2012 to $140.0 \mathrm{~m}^{3} \mathrm{~s}^{-1}$ during 2011. 
Table 3.3. Summary of average daily climate statistics from 2010 - 2013 for five gauging sites located in Hinkson Creek Watershed, Missouri, USA. Precipitation values are annual totals.

\begin{tabular}{|c|c|c|c|c|c|c|c|}
\hline Data & Date & Statistic & Site \#1 & Site \#2 & Site \#3 & Site \#4 & Site \#5 \\
\hline \multirow{5}{*}{$\begin{array}{l}\text { Precipitation } \\
(\mathrm{mm})\end{array}$} & 2010 & Total & 1310 & 1310 & 1342 & 1325 & 1329 \\
\hline & 2011 & Total & 854 & 859 & 910 & 922 & 890 \\
\hline & 2012 & Total & 664 & 639 & 696 & 673 & 670 \\
\hline & 2013 & Total & 1086 & 1062 & 1057 & 1054 & 1035 \\
\hline & Study & Mean & 988 & 974 & 1007 & 1002 & 986 \\
\hline \multirow{15}{*}{$\begin{array}{l}\text { Streamflow } \\
\left(\mathrm{m}^{3} \mathrm{~s}^{-1}\right)\end{array}$} & 2010 & Min & 0.0 & 0.0 & 0.1 & 0.1 & 0.2 \\
\hline & & Median & 0.2 & 0.2 & 0.3 & 0.5 & 0.8 \\
\hline & & Max & 54.0 & 60.0 & 83.0 & 110.0 & 140.0 \\
\hline & 2011 & Min & 0.0 & 0.0 & 0.0 & 0.0 & 0.0 \\
\hline & & Median & 0.0 & 0.1 & 0.2 & 0.3 & 0.5 \\
\hline & & Max & 16.0 & 21.0 & 28.0 & 36.0 & 58.0 \\
\hline & 2012 & Min & 0.0 & 0.1 & 0.0 & 0.0 & 0.1 \\
\hline & & Median & 0.0 & 0.1 & 0.1 & 0.1 & 0.3 \\
\hline & & Max & 13.0 & 15.0 & 21.0 & 36.20 & 53.0 \\
\hline & 2013 & Min & 0.0 & 0.0 & 0.0 & 0.0 & 0.2 \\
\hline & & Median & 0.0 & 0.1 & 0.1 & 0.2 & 0.5 \\
\hline & & Max & 58.0 & 66.0 & 87.0 & 110.0 & 14.0 \\
\hline & Study & Min & 0.0 & 0.0 & 0.0 & 0.0 & 0.0 \\
\hline & & Median & 0.0 & 0.1 & 0.1 & 0.2 & 0.5 \\
\hline & & Max & 58.0 & 66.0 & 87.0 & 110.0 & 140.0 \\
\hline
\end{tabular}

Min = minimum, Max = maximum, Study = study period.

\section{Observed nutrient concentrations}

Observed median nutrient concentrations $\left(\mathrm{NH}_{3}-\mathrm{N}, \mathrm{NO}_{3}-\mathrm{N}\right.$, TIN-N, and TP-P)

were significantly greater $(p<0.001)$ at agricultural Site \#Site \#1 compared to all other sites with the exception of nitrite (Table 3.4). Multiple linear regression analysis resulted in a positive relationship between agricultural and urban land use and TIN-N $(p=0.043$, $\left.R^{2}=0.913\right)$ and TP-P $\left(p=0.069, R^{2}=0.862\right)$. Nitrogen concentrations $\left(\mathrm{NH}_{3}-\mathrm{N}, \mathrm{NO}_{3}-\mathrm{N}\right.$, $\mathrm{NO}_{2}-\mathrm{N}, \mathrm{TIN}-\mathrm{N}$ ) decreased significantly from Site \#Site \#1 to Site \#Site \#2, but were not significantly different between rural Site \#Site \#2, and the urban Sites \#3, \#4, and \#5 with the exception of $\mathrm{NH}_{3}-\mathrm{N}$. Total ammonia significantly increased $(p<0.001)$ by $0.012 \mathrm{mg}$ 
$\mathrm{L}^{-1}$ between Sites \#2 and \#3 at the rural/urban interface, and between Sites \#4 and \#5 as urban land use area increased from 36.7 to $54.4 \mathrm{~km}^{2}$. Total phosphorus was significantly greater $(p<0.001)$ where cumulative urban land use area was greatest at Site \#Site \#5 (TP-P=0.151 mg L ${ }^{-1}$ ) in comparison to all sites except agricultural Site \#Site \#1. Maximum $\mathrm{NO}_{2}-\mathrm{N}, \mathrm{NO}_{3}-\mathrm{N}$, and TIN-N concentrations were greatest at agriculture dominated Site \#Site \#1 and decreased with stream distance. However, maximum $\mathrm{NH}_{3}-\mathrm{N}$ and TP-P concentrations were greater at urban sites. For example, maximum $\mathrm{NO}_{2}-\mathrm{N}$, $\mathrm{NO}_{3}-\mathrm{N}$, and TIN-N were $0.600,5.01,5.57 \mathrm{mg} \mathrm{L}^{-1}$ at agricultural Site \#Site \#1. Total ammonia concentrations exceeded $1.500 \mathrm{mg} \mathrm{L}^{-1}$ at urban Site \#Site \#3, while TP-P exceeded $1.00 \mathrm{mg} \mathrm{L}^{-1}$ at urban Sites \#3 $\left(1.23 \mathrm{mg} \mathrm{L}^{-1}\right)$ to \#5 $\left(1.15 \mathrm{mg} \mathrm{L}^{-1}\right)$ during the study (Table 3.4). 
Table 3.4. Summary of statistics for observed nutrient concentrations ( $n=858$ sample days per site) from 2010 - 2013 at five gauging sites measured in Hinkson Creek, Missouri, USA.

\begin{tabular}{|c|c|c|c|c|c|c|}
\hline Element & Statistic & Site \#1 & Site \#2 & Site \#3 & Site \#4 & Site \#5 \\
\hline \multirow{5}{*}{$\begin{array}{l}\mathrm{NH}_{3}-\mathrm{N} \\
\left(\mathrm{mg} \mathrm{L}^{-1}\right)\end{array}$} & Mean & 0.111 & 0.073 & 0.085 & 0.079 & 0.092 \\
\hline & Std. Dev. & 0.099 & 0.071 & 0.096 & 0.072 & 0.073 \\
\hline & Min & 0.014 & 0.021 & 0.005 & 0.015 & 0.021 \\
\hline & Median & $0.072 \mathrm{abc}$ & 0.049 adef & $0.055 \mathrm{bdg}$ & $0.056 \mathrm{ceh}$ & $0.071 \mathrm{fgh}$ \\
\hline & $\operatorname{Max}$ & 0.794 & 0.648 & 1.500 & 0.768 & 0.812 \\
\hline \multirow{5}{*}{$\begin{array}{l}\mathrm{NO}_{2}-\mathrm{N} \\
\left(\mathrm{mg} \mathrm{L}^{-1}\right)\end{array}$} & Mean & 0.045 & 0.038 & 0.038 & 0.038 & 0.040 \\
\hline & Std. Dev. & 0.046 & 0.040 & 0.035 & 0.036 & 0.034 \\
\hline & Min & 0.001 & 0.007 & 0.001 & 0.006 & 0.004 \\
\hline & Median & $0.029 \mathrm{abc}$ & $0.026 \mathrm{ad}$ & 0.026 be & $0.026 \mathrm{cf}$ & $0.029 \mathrm{def}$ \\
\hline & $\operatorname{Max}$ & 0.600 & 0.580 & 0.335 & 0.386 & 0.309 \\
\hline \multirow{5}{*}{$\begin{array}{l}\mathrm{NO}_{3}-\mathrm{N} \\
\left(\mathrm{mg} \mathrm{L}^{-1}\right)\end{array}$} & Mean & 0.684 & 0.535 & 0.524 & 0.506 & 0.504 \\
\hline & Std. Dev. & 0.579 & 0.471 & 0.420 & 0.365 & 0.357 \\
\hline & Min & 0.026 & 0.063 & 0.069 & 0.115 & 0.107 \\
\hline & Median & $0.467 \mathrm{abcd}$ & $0.328 \mathrm{a}$ & $0.339 \mathrm{~b}$ & $0.365 \mathrm{c}$ & $0.374 \mathrm{~d}$ \\
\hline & $\operatorname{Max}$ & 5.010 & 4.060 & 3.380 & 3.220 & 2.920 \\
\hline \multirow{5}{*}{$\begin{array}{l}\text { TIN-N } \\
\left(\mathrm{mg} \mathrm{L}^{-1}\right)\end{array}$} & Mean & 0.840 & 0.646 & 0.647 & 0.623 & 0.636 \\
\hline & Std. Dev. & 0.663 & 0.551 & 0.506 & 0.442 & 0.431 \\
\hline & Min & 0.079 & 0.121 & 0.166 & 0.177 & 0.151 \\
\hline & Median & $0.603 \mathrm{abcd}$ & 0.404 aef & $0.425 \mathrm{~b}$ & 0.450 ce & $0.486 \mathrm{df}$ \\
\hline & Max & 5.570 & 4.520 & 4.380 & 4.370 & 3.570 \\
\hline \multirow{5}{*}{$\begin{array}{l}\text { TP-P } \\
\left(\mathrm{mg} \mathrm{L}^{-1}\right)\end{array}$} & Mean & 0.127 & 0.088 & 0.087 & 0.084 & 0.102 \\
\hline & Std. Dev. & 0.121 & 0.100 & 0.108 & 0.109 & 0.115 \\
\hline & Min & 0.002 & 0.000 & 0.000 & 0.000 & 0.000 \\
\hline & Median & $0.091 \mathrm{abcd}$ & 0.057 aef & $0.053 \mathrm{bg}$ & 0.049 ceh & $0.068 \mathrm{dfgh}$ \\
\hline & Max & 0.907 & 1.050 & 1.240 & 1.130 & 1.150 \\
\hline
\end{tabular}

Std. Dev. is standard deviation, Min is minimum, and Max is maximum. $\mathrm{NH}_{3}-\mathrm{N}$ is total ammonia, $\mathrm{NO}_{2}-\mathrm{N}$ is nitrite, $\mathrm{NO}_{3}-\mathrm{N}$ is nitrate, TIN-N is total inorganic nitrogen, and TP-P is total phosphorus.

$\S$ Median concentrations followed with the same letter were significantly different $(\alpha<0.05)$

\section{Flow-weighted concentrations}

Annual flow-weighted concentration analyses (FWCs) resulted in $\mathrm{NH}_{3}-\mathrm{N}, \mathrm{NO}_{2}-\mathrm{N}$, $\mathrm{NO}_{3}-\mathrm{N}, \mathrm{TIN}-\mathrm{N}$ and TP-P ranged from $0.172-0.205 \mathrm{mg} \mathrm{L}^{-1}, 0.091-0.108 \mathrm{mg} \mathrm{L}^{-1}, 1.00-$ $1.20 \mathrm{mg} \mathrm{L}^{-1}, 1.26-1.51 \mathrm{mg} \mathrm{L}^{-1}$, and $0.236-0.294 \mathrm{mg} \mathrm{L}^{-1}$, respectively (Table 3.5 ). Average annual flow weighted nutrient concentrations (FWCs) decreased by an average 
of $13 \%$ over $7 \mathrm{~km}$ of stream distance from Site \#Site \#1 to Site \#Site \#2. Nutrient concentrations increased by an average of 3\% at the rural / urban interface (between Sites \#2 and \#3) as urban land use increased by $6 \%$. Ultimately, average annual FWCs decreased by an average $18 \%$ difference with downstream distance from the headwaters (Site \#Site \#1) toward the watershed outlet (Site \#Site \#5) as agricultural land use decreased by $18 \%$, and urban land use increased by $22 \%$. Results from multiple linear regression analyses confirmed a significant relationship between agricultural land use, urban land use, and annual FWCs $(p<0.054)$ accounting for $89-97 \%$ of the variance in annual FWCs (Table 3.6), with the exception of $\mathrm{NO}_{2}-\mathrm{N}(p=0.146)$. Percent differences in annual FWCs of inorganic N were greatest during 2012 (year of drought) and least during 2010 (record setting wet year) indicating decreased nutrient attenuation during wet years. The change in annual FWCs from Site \#Site \#1 in the headwaters to Site \#Site \#5 near the watershed outlet was significantly correlated with annual precipitation $(p=0.001$, $n=20)$. The explained variance increased by $22.3 \%\left(R^{2}=0.647\right)$ when TP was removed from the analysis $(p<0.001, n=16)$.

Seasonal median FWCs were significantly greater $(p<0.001)$ during the $1^{\text {st }}$ and $2^{\text {nd }}$ quarters compared to the $3^{\text {rd }}$ and $4^{\text {th }}$ quarters for every nutrient (Table 3.5). Seasonal average FWCs increased as urban land use increased from Sites \#2 to \#5 during the drier months of the $3^{\text {rd }}$ quarter (July, August, and September). This trend was not observed in the $1^{\text {st }}, 2^{\text {nd }}$, or $4^{\text {th }}$ quarters. Multiple regression analysis showed total precipitation and mean air temperature accounted for 25 to $37 \%$ of the explained variance in seasonal FWCs $(p<0.001, n=20)$. Reducing the data by averaging to a five-site mean increased the 
explained variance in seasonal FWCs of $\mathrm{NH}_{3}-\mathrm{N}, \mathrm{NO}_{2}-\mathrm{N}, \mathrm{NO}_{3}-\mathrm{N}, \mathrm{TIN}-\mathrm{N}$, and TP-P to 83, $95,96,94$, and $88 \%$, respectively $(p>0.05, n=4)$.

Table 3.5. Annual $(n=4)$ and seasonal average flow weighted mean nutrient concentrations at each gauging site and each element from 2010 - 2013 measured in Hinkson Creek, Missouri, USA.

\begin{tabular}{|c|c|c|c|c|c|c|}
\hline Element & Site \# & $1^{\text {st }}$ Quarter & $2^{\text {nd }}$ Quarter & $3^{\text {rd }}$ Quarter & $4^{\text {th }}$ Quarter & Annual \\
\hline $\mathrm{NH}_{3}-\mathrm{N}$ & 1 & 0.223 & 0.206 & 0.106 & 0.140 & 0.205 \\
\hline \multirow[t]{4}{*}{$\left(\mathrm{mg} \mathrm{L}^{-1}\right)$} & 2 & 0.191 & 0.180 & 0.064 & 0.102 & 0.176 \\
\hline & 3 & 0.186 & 0.200 & 0.084 & 0.121 & 0.186 \\
\hline & 4 & 0.161 & 0.186 & 0.086 & 0.092 & 0.166 \\
\hline & 5 & 0.182 & 0.179 & 0.108 & 0.089 & 0.172 \\
\hline $\mathrm{NO}_{2}-\mathrm{N}$ & 1 & 0.107 & 0.116 & 0.044 & 0.064 & 0.108 \\
\hline \multirow[t]{4}{*}{$\left(\mathrm{mg} \mathrm{L}^{-1}\right)$} & 2 & 0.096 & 0.107 & 0.036 & 0.049 & 0.097 \\
\hline & 3 & 0.092 & 0.115 & 0.040 & 0.057 & 0.100 \\
\hline & 4 & 0.082 & 0.113 & 0.050 & 0.052 & 0.096 \\
\hline & 5 & 0.090 & 0.102 & 0.055 & 0.045 & 0.091 \\
\hline $\mathrm{NO}_{3}-\mathrm{N}$ & 1 & 1.280 & 1.230 & 0.547 & 1.010 & 1.200 \\
\hline \multirow[t]{4}{*}{$\left(\mathrm{mg} \mathrm{L}^{-1}\right)$} & 2 & 1.160 & 1.140 & 0.414 & 0.712 & 1.060 \\
\hline & 3 & 1.120 & 1.160 & 0.487 & 0.750 & 1.080 \\
\hline & 4 & 1.040 & 1.080 & 0.621 & 0.698 & 1.010 \\
\hline & 5 & 1.050 & 1.060 & 0.591 & 0.563 & 1.000 \\
\hline TIN-N & 1 & 1.610 & 1.550 & 0.697 & 1.220 & 1.510 \\
\hline \multirow[t]{4}{*}{$\left(\mathrm{mg} \mathrm{L}^{-1}\right)$} & 2 & 1.450 & 1.430 & 0.514 & 0.863 & 1.340 \\
\hline & 3 & 1.400 & 1.470 & 0.611 & 0.928 & 1.360 \\
\hline & 4 & 1.280 & 1.380 & 0.757 & 0.842 & 1.270 \\
\hline & 5 & 1.330 & 1.340 & 0.753 & 0.696 & 1.260 \\
\hline TP-P & 1 & 0.311 & 0.285 & 0.153 & 0.225 & 0.294 \\
\hline \multirow[t]{4}{*}{$\left(\mathrm{mg} \mathrm{L}^{-1}\right)$} & 2 & 0.252 & 0.279 & 0.096 & 0.124 & 0.258 \\
\hline & 3 & 0.254 & 0.297 & 0.093 & 0.123 & 0.268 \\
\hline & 4 & 0.221 & 0.274 & 0.113 & 0.119 & 0.242 \\
\hline & 5 & 0.236 & 0.256 & 0.147 & 0.119 & 0.236 \\
\hline
\end{tabular}

$\mathrm{NH}_{3}-\mathrm{N}$ is total ammonia, $\mathrm{NO}_{2}-\mathrm{N}$ is nitrite, $\mathrm{NO}_{3}-\mathrm{N}$ is nitrate, $\mathrm{TIN}-\mathrm{N}$ is total inorganic nitrogen, and TP-P is total phosphorus 
Table 3.6. Parameters of log space discharge-load multiple regression equations for annual flow weighted mean nutrient concentrations (nutrient rating curves) as a function of land use generated using input data (daily average discharge) collected during 2010 2013 at five gauging sites in Hinkson Creek Watershed, Missouri, USA.

\begin{tabular}{lrrrr}
\hline $\mathrm{Y}$ & \multicolumn{1}{l}{$\mathrm{B}_{0}$} & \multicolumn{1}{l}{$\mathrm{X}_{1}$} & \multicolumn{2}{l}{$\mathrm{X}_{2}$} \\
\hline $\mathrm{NH}_{3}-\mathrm{N}$ & -2.197 & 0.032 & 0.04 & 0.931 \\
$\mathrm{NO}_{2}-\mathrm{N}$ & -0.536 & 0.008 & 0.011 & 0.708 \\
$\mathrm{NO}_{3}-\mathrm{N}$ & -8.749 & 0.131 & 0.164 & 0.966 \\
$\mathrm{TIN}-\mathrm{N}$ & -11.558 & 0.173 & 0.215 & 0.960 \\
$\mathrm{TP}-\mathrm{P}$ & -2.228 & 0.033 & 0.042 & 0.892 \\
\hline
\end{tabular}

$Y$ is the independent variable, $B_{0}$ is the y-intercept, $X_{1}$ is the coefficient corresponding to cumulative percent urban land use, $X_{2}$ is the coefficient corresponding to cumulative percent agricultural land use.

Nutrient concentrations were generally greater from February to June. For example, monthly maximum TIN-N FWCs exceeded $1.95 \mathrm{mg} \mathrm{L}^{-1}$ and $3.47 \mathrm{mg} \mathrm{L}^{-1}$ during February and June, respectively. Peaks in monthly maximum TIN-N (1.08 to $2.95 \mathrm{mg} \mathrm{L}^{-}$ ${ }^{1}$ ) and TP-P (0.308 to $\left.0.514 \mathrm{mg} \mathrm{L}^{-1}\right)$ were also observed in December. Similar to other results, monthly average nutrient FWCs were generally greater at Site \#Site \#1 compared to other sites. Monthly average $\mathrm{NH}_{3}-\mathrm{N}$ FWCs were approximately $20 \mu \mathrm{g} \mathrm{L}^{-1}$ greater at Site \#Site \#3 compared to Site \#Site \#1 during November, and $10 \mu \mathrm{g} \mathrm{L}{ }^{-1}$ greater at Site \#Site \#5 compared to Site \#Site \#1 during September.

\section{Nutrient yields}

The 4 methods used to calculate annual nutrient loads $\left(\mathrm{t} \mathrm{yr}^{-1}\right)$ included linear interpolation (Method 1), average sample load (Method 2), average sample concentration times average sample discharge (Method 3), and log space discharge-load regression (Method 4) and loading estimates are presented at nutrient yields ( $\left.\mathrm{t} \mathrm{ha}^{-1} \mathrm{yr}^{-1}\right)$. Method 4 required development of linear regression relationships. Results from log space discharge-load regression relationships showed discharge accounted for 84.4 to $94.1 \%$ of the explained variance in nutrient yields (Figure 3.2). When nutrient rating curves were 
validated using one year of observed data (2013), the algorithms tested were associated with at least a rating of good (Moriasi et al. 2007). For example, five-site mean NSE values ranged from 0.69 (good) for monthly $\mathrm{NH}_{3}-\mathrm{N}$ yields to 0.89 (very good) for monthly $\mathrm{NO}_{3}-\mathrm{N}$ yields. The five-site mean $\mathrm{RSR}$ values ranged from 0.13 (very good) for monthly TIN-N yields to 0.19 (very good) for monthly TP-P yields. And, five-site mean PBIAS values ranged from $1.1 \%$ (very good) for monthly $\mathrm{NO}_{3}-\mathrm{N}$ yields to $37.8 \%$ (good) for monthly TP-P yields. 


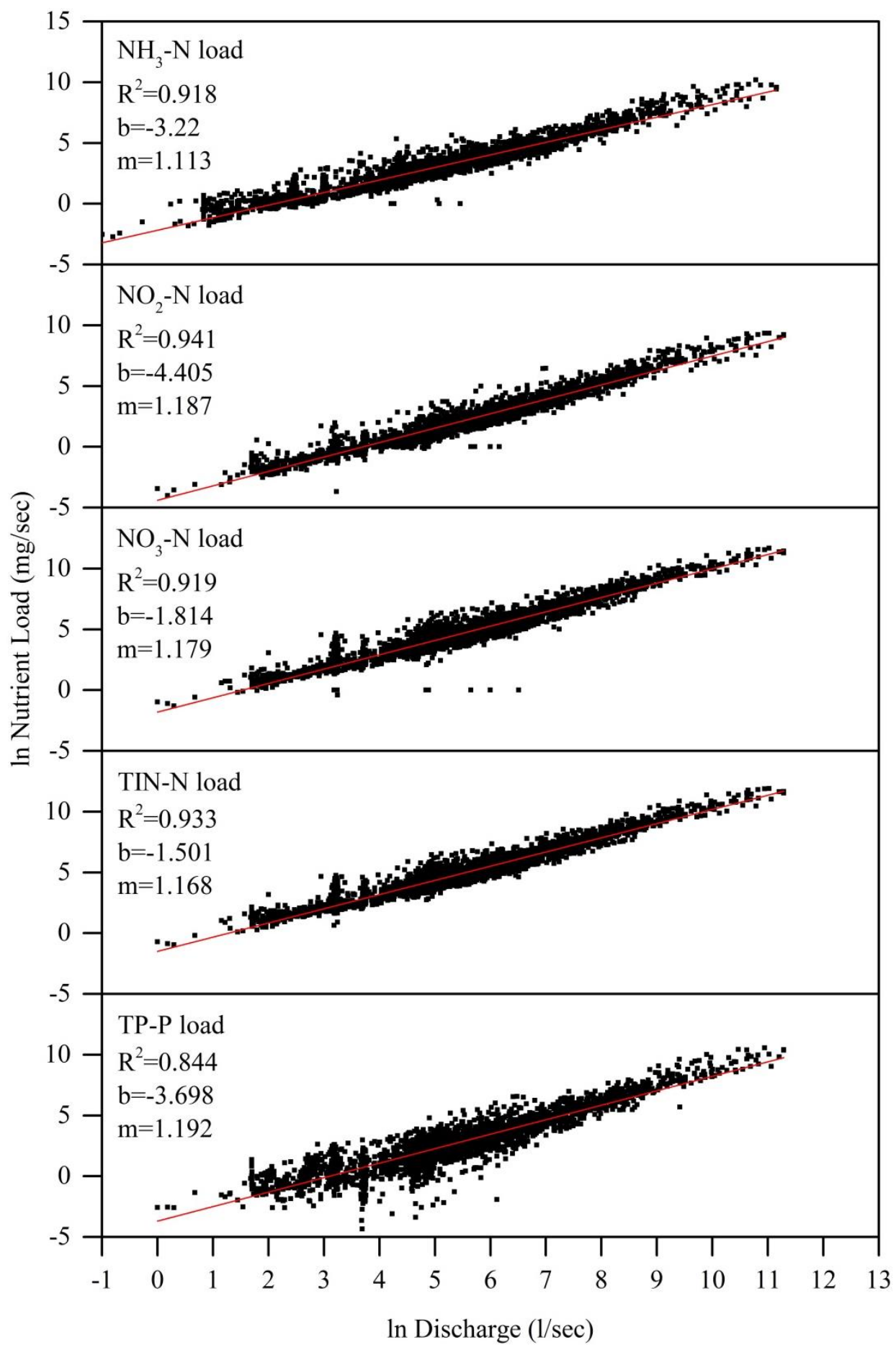

Figure 3.2. Log space discharge-load regression relationships ( $n=616)$ developed using three years (2010 - 2012) of data collected during the study period (2010 - 2013) from five gauging sites in Hinkson Creek Watershed, Missouri, USA.

72 
Methods 1, 2, and 4 generally resulted in similar estimates of nutrient yields. However, Method 3 (average sample concentration x average sample discharge) resulted in significantly lesser estimates of nutrient yield relative to Methods 1 and 2 for every element tested ( $p<0.003, n=4)$ (Table 3.7). Significant differences were not found between Methods 1 , and 2 for any element $(p>0.05, n=4)$. Significant differences were also found between Methods 1 and 4 for $\mathrm{NH}_{3}-\mathrm{N}$ yield ranging from 6 to $44 \%$ difference $(p=0.028, n=4)$. 
Table 3.7. Comparisons of results using four methods used to estimate annual nutrient yields in Hinkson Creek Watershed, Missouri, USA. Method 1 is linear interpolation, Method 2 is average sample load, Method 3 is average sample concentration times average sample discharge, and Method 4 is log space discharge-load regression.

\begin{tabular}{|c|c|c|c|c|c|}
\hline Element & Site \# & Method 1 & Method 2 & Method 3 & Method 4 \\
\hline $\mathrm{NH}_{3}-\mathrm{N}^{*}$ & 1 & 0.859 & 0.612 & 0.325 & 0.685 \\
\hline \multirow[t]{4}{*}{$\left(\mathrm{kg} \mathrm{ha}^{-1} \mathrm{yr}^{-1}\right)$} & 2 & 0.687 & 0.565 & 0.224 & 0.394 \\
\hline & 3 & 0.837 & 0.734 & 0.294 & 0.446 \\
\hline & 4 & 0.701 & 0.638 & 0.261 & 0.437 \\
\hline & 5 & 0.829 & 0.856 & 0.344 & 0.486 \\
\hline $\mathrm{NO}_{2}-\mathrm{N}$ & 1 & 0.457 & 0.346 & 0.130 & 0.503 \\
\hline \multirow[t]{4}{*}{$\left(\mathrm{kg} \mathrm{ha}^{-1} \mathrm{yr}^{-1}\right)$} & 2 & 0.363 & 0.301 & 0.108 & 0.257 \\
\hline & 3 & 0.433 & 0.423 & 0.143 & 0.287 \\
\hline & 4 & 0.379 & 0.378 & 0.128 & 0.283 \\
\hline & 5 & 0.428 & 0.472 & 0.144 & 0.314 \\
\hline $\mathrm{NO}_{3}-\mathrm{N}$ & 1 & 4.730 & 3.730 & 1.940 & 6.210 \\
\hline \multirow[t]{4}{*}{$\left(\mathrm{kg} \mathrm{ha}^{-1} \mathrm{yr}^{-1}\right)$} & 2 & 3.840 & 3.290 & 1.520 & 3.150 \\
\hline & 3 & 4.430 & 4.390 & 2.150 & 3.520 \\
\hline & 4 & 3.950 & 3.990 & 1.940 & 3.470 \\
\hline & 5 & 4.670 & 4.740 & 1.990 & 3.850 \\
\hline TIN-N & 1 & 6.050 & 4.690 & 2.400 & 7.330 \\
\hline \multirow[t]{4}{*}{$\left(\mathrm{kg} \mathrm{ha}^{-1} \mathrm{yr}^{-1}\right)$} & 2 & 4.890 & 4.160 & 1.850 & 3.810 \\
\hline & 3 & 5.700 & 5.540 & 2.590 & 4.270 \\
\hline & 4 & 5.030 & 5.000 & 2.330 & 4.210 \\
\hline & 5 & 5.960 & 6.070 & 2.480 & 4.670 \\
\hline TP-P*§ & 1 & 1.160 & 0.883 & 0.334 & 0.913 \\
\hline \multirow[t]{4}{*}{$\left(\mathrm{kg} \mathrm{ha}^{-1} \mathrm{yr}^{-1}\right)$} & 2 & 0.966 & 0.730 & 0.243 & 0.543 \\
\hline & 3 & 1.130 & 0.977 & 0.315 & 0.607 \\
\hline & 4 & 0.872 & 0.891 & 0.273 & 0.598 \\
\hline & 5 & 1.060 & 1.160 & 0.354 & 0.664 \\
\hline
\end{tabular}

* Significant differences $(\alpha=0.05)$ were found between Methods \#1 and \#4. $\S$ Significant differences $(\alpha=0.05)$ were found between Methods $\# 2$ and $\# 4$.

$\mathrm{NH}_{3}-\mathrm{N}$ is total ammonia, $\mathrm{NO}_{2}-\mathrm{N}$ is nitrite, $\mathrm{NO}_{3}-\mathrm{N}$ is nitrate, TIN-N is total inorganic nitrogen, and TP-P is total phosphorus.

Method 1 was chosen as the best estimate of nutrient yields because the sampling frequency captured enough of the variability in nutrient concentrations (Letcher et al., 1999; Quilbe et al., 2006). Average annual $\mathrm{NH}_{3}-\mathrm{N}, \mathrm{NO}_{2}-\mathrm{N}, \mathrm{NO}_{3}-\mathrm{N}$, TIN-N, and TP-P yields were $0.742,0.400,4.24,5.38$, and $0.979 \mathrm{~kg} \mathrm{ha}^{-1} \mathrm{yr}^{-1}$, respectively, at Site \#Site \#5 
during the four year study (2010-2013) (Table 3.8). Annual TIN-N yield was composed of $80 \% \mathrm{NO}_{3}-\mathrm{N}, 13 \% \mathrm{NH}_{3}-\mathrm{N}$, and $7 \% \mathrm{NO}_{2}-\mathrm{N}$. Nutrient yields were significantly lesser ( $p<0.003$ ) during 2012 relative to all other years of the study period attributable to less than average rainfall/runoff. Total inorganic nitrogen and TP-P nutrient yields were not significantly different between the 2010 and 2013 years $(p>0.05)$. Annual precipitation accounted for 68 to $85 \%$ of the explained variance in nutrient yields $(p<0.001, n=20)$. A source - sink effect was observed in multiple regression analysis where preceding year (i.e. antecedent) annual precipitation increased explained variance in nutrient yields by 4 to $19 \%(p<0.001, n=20)$. 
Table 3.8. Total annual nutrient yields estimated using linear interpolation (Method 1) from 2010 - 2013 at five gauging sites in Hinkson Creek Watershed, Missouri, USA.

\begin{tabular}{|c|c|c|c|c|c|c|}
\hline Element & Site \# & 2010 & 2011 & 2012 & 2013 & Study \\
\hline $\mathrm{NH}_{3}-\mathrm{N}$ & 1 & 1.360 & 0.463 & 0.106 & 1.250 & 0.796 \\
\hline \multirow[t]{4}{*}{$\left(\mathrm{kg} \mathrm{ha}^{-1} \mathrm{yr}^{-1}\right)$} & 2 & 1.120 & 0.504 & 0.089 & 0.870 & 0.647 \\
\hline & 3 & 1.300 & 0.543 & 0.142 & 1.130 & 0.780 \\
\hline & 4 & 0.987 & 0.449 & 0.146 & 0.952 & 0.634 \\
\hline & 5 & 1.130 & 0.535 & 0.179 & 1.120 & 0.742 \\
\hline $\mathrm{NO}_{2}-\mathrm{N}$ & 1 & 0.771 & 0.217 & 0.058 & 0.697 & 0.435 \\
\hline \multirow[t]{4}{*}{$\left(\mathrm{kg} \mathrm{ha}^{-1} \mathrm{yr}^{-1}\right)$} & 2 & 0.662 & 0.242 & 0.056 & 0.485 & 0.361 \\
\hline & 3 & 0.807 & 0.260 & 0.078 & 0.605 & 0.437 \\
\hline & 4 & 0.629 & 0.219 & 0.093 & 0.540 & 0.370 \\
\hline & 5 & 0.648 & 0.251 & 0.097 & 0.605 & 0.400 \\
\hline $\mathrm{NO}_{3}-\mathrm{N}$ & 1 & 8.180 & 2.410 & 0.753 & 7.060 & 4.600 \\
\hline \multirow[t]{4}{*}{$\left(\mathrm{kg} \mathrm{ha}^{-1} \mathrm{yr}^{-1}\right)$} & 2 & 6.670 & 2.980 & 0.715 & 4.700 & 3.760 \\
\hline & 3 & 7.860 & 3.210 & 0.977 & 5.660 & 4.430 \\
\hline & 4 & 6.060 & 2.810 & 1.030 & 5.070 & 3.740 \\
\hline & 5 & 6.310 & 3.030 & 1.190 & 6.410 & 4.240 \\
\hline TIN-N & 1 & 10.30 & 3.090 & 0.916 & 9.010 & 5.830 \\
\hline \multirow[t]{4}{*}{$\left(\mathrm{kg} \mathrm{ha}^{-1} \mathrm{yr}^{-1}\right)$} & 2 & 8.450 & 3.720 & 0.860 & 6.050 & 4.770 \\
\hline & 3 & 9.970 & 4.010 & 1.200 & 7.400 & 5.640 \\
\hline & 4 & 7.680 & 3.490 & 1.260 & 6.560 & 4.750 \\
\hline & 5 & 8.090 & 3.820 & 1.470 & 8.130 & 5.380 \\
\hline TP-P & 1 & 1.830 & 0.494 & 0.194 & 2.040 & 1.140 \\
\hline \multirow[t]{4}{*}{$\left(\mathrm{kg} \mathrm{ha}^{-1} \mathrm{yr}^{-1}\right)$} & 2 & 1.440 & 0.599 & 0.197 & 1.330 & 0.893 \\
\hline & 3 & 1.700 & 0.689 & 0.285 & 1.570 & 1.060 \\
\hline & 4 & 1.280 & 0.557 & 0.345 & 1.190 & 0.841 \\
\hline & 5 & 1.430 & 0.689 & 0.318 & 1.480 & 0.979 \\
\hline
\end{tabular}

$\mathrm{NH}_{3}-\mathrm{N}$ is total ammonia, $\mathrm{NO}_{2}-\mathrm{N}$ is nitrite, $\mathrm{NO}_{3}-\mathrm{N}$ is nitrate, $\mathrm{TIN}-\mathrm{N}$ is total inorganic nitrogen, and TP-P is total phosphorus.

\section{Discussion}

The study period (2010 - 2013) of this investigation included four hydrologically distinct years, thereby consisting of ideal conditions for monitoring nutrient concentrations and yield trends during wet, average, and extreme drought years (Table 3.3, Figure 3.3). While 2010 was a record wet year (approximately $1323 \mathrm{~mm}$ of rainfall), 2012 was characterized by extreme to exceptional (D3 to D4) drought conditions 
(approximately $639 \mathrm{~mm}$ of rainfall) (NOAA, 2012). Precipitation ranged from approximately $400 \mathrm{~mm}$ drier to $250 \mathrm{~mm}$ wetter than the 30 -year average of $1082 \mathrm{~mm} \mathrm{yr}^{-1}$ reported in a study by Hubbart and Zell (2013) from the same watershed. Multiple regression results between precipitation and nutrient yields indicated the extremes in annual precipitation during the two years prior to 2010 (1448 and $1350 \mathrm{~mm}$ of precipitation, respectively) and 2013 (660 $\mathrm{mm}$ of precipitation) affected nutrient yields. Similar findings were reported by other authors in recent literature (Royer et al., 2006; Shields et al., 2008; Kaushal et al., 2008). 


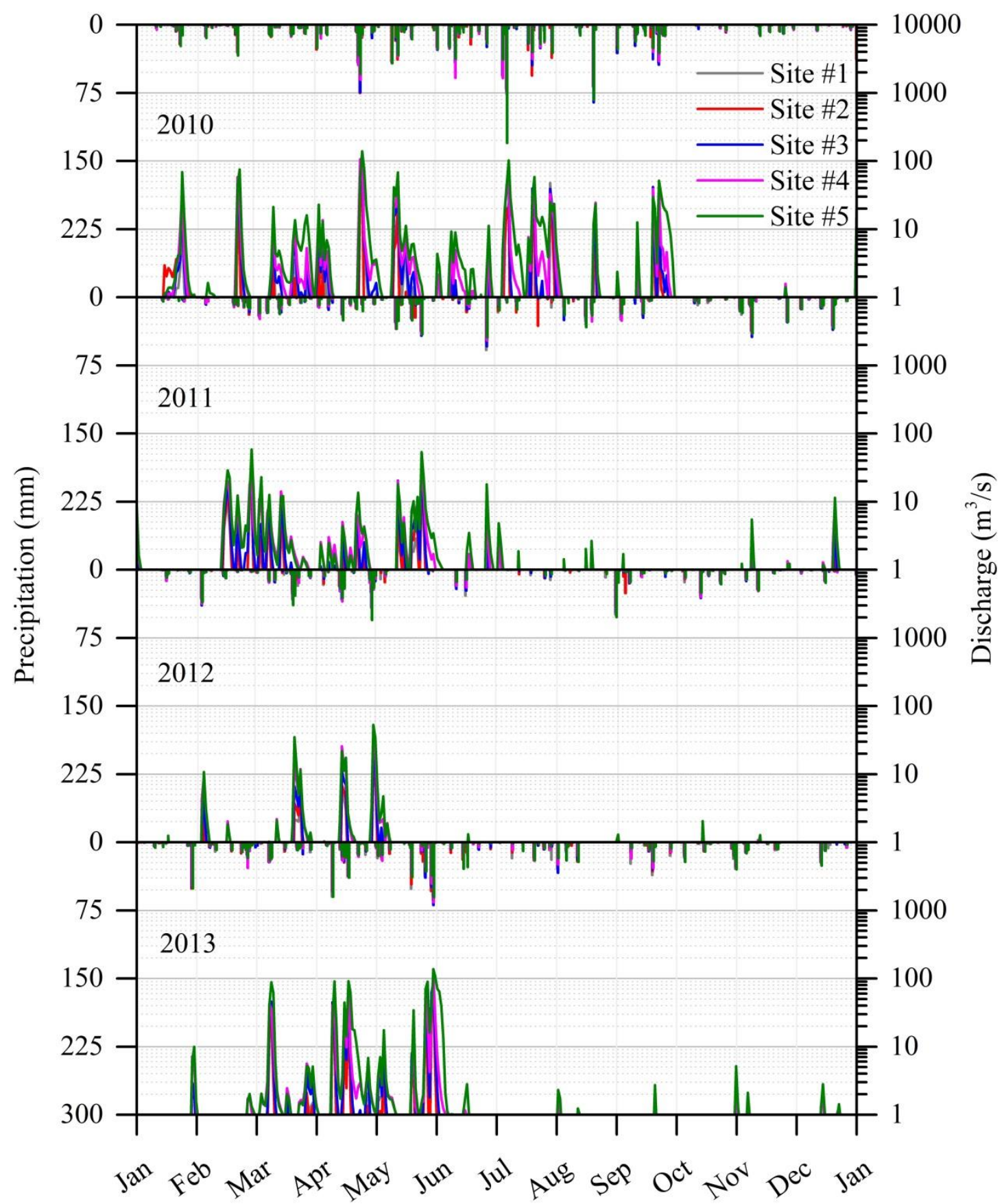

Figure 3.3. Precipitation (left axis-linear) and discharge (right axis-log base 10) data shown for each year from 2010 - 2013 at five gauging sites located in Hinkson Creek Watershed, Missouri, USA.

Total inorganic nitrogen and TP-P nutrient yields were not significantly different between the 2010 and 2013 years $(C I=95 \%, p=0.188)$. However, 2010 was significantly wetter than average with annual total precipitation $\sim 250 \mathrm{~mm}$ greater than the 20 -yr 
average while 2013 was close to the norm within $25 \mathrm{~mm}$ of the 20 -yr average ( $C I=95 \%$, $p<0.001)$. The two years of record setting annual total precipitation preceding 2010 presumably flushed nutrients from the terrestrial catchment. Conversely, the two years prior to 2013 were drier than average, including a period of drought during 2012, when nutrients likely built-up in the overland terrestrial system, thus highlighting classic sink source processes for pollutant loading (Sator et al., 1974). These results indicated that nutrient retention on the landscape decreases with increasing annual total precipitation (Figure 3.4). However, total phosphorus was the exception. For example, percent differences in annual FWCs between Site \#Site \#1 and Site \#Site \#5 for all forms of inorganic N were greatest during the drought year of 2012 (average annual total precipitation $=669 \mathrm{~mm}$ ), and least during the wettest year of 2010 (average annual total precipitation $=1323 \mathrm{~mm}$ ), with percent differences ranging from 26 to $33 \%$ during 2012 , and 8 to $17 \%$ during 2010. Conversely, percent differences in annual FWCs of TP-P between Site \#1 and Site \#5 were greatest during 2013 (average annual total precipitation $=1059 \mathrm{~mm})$, and least during 2011 (average annual total precipitation $=887 \mathrm{~mm})$, with percent differences of $29 \%$ and $7 \%$, respectively. 


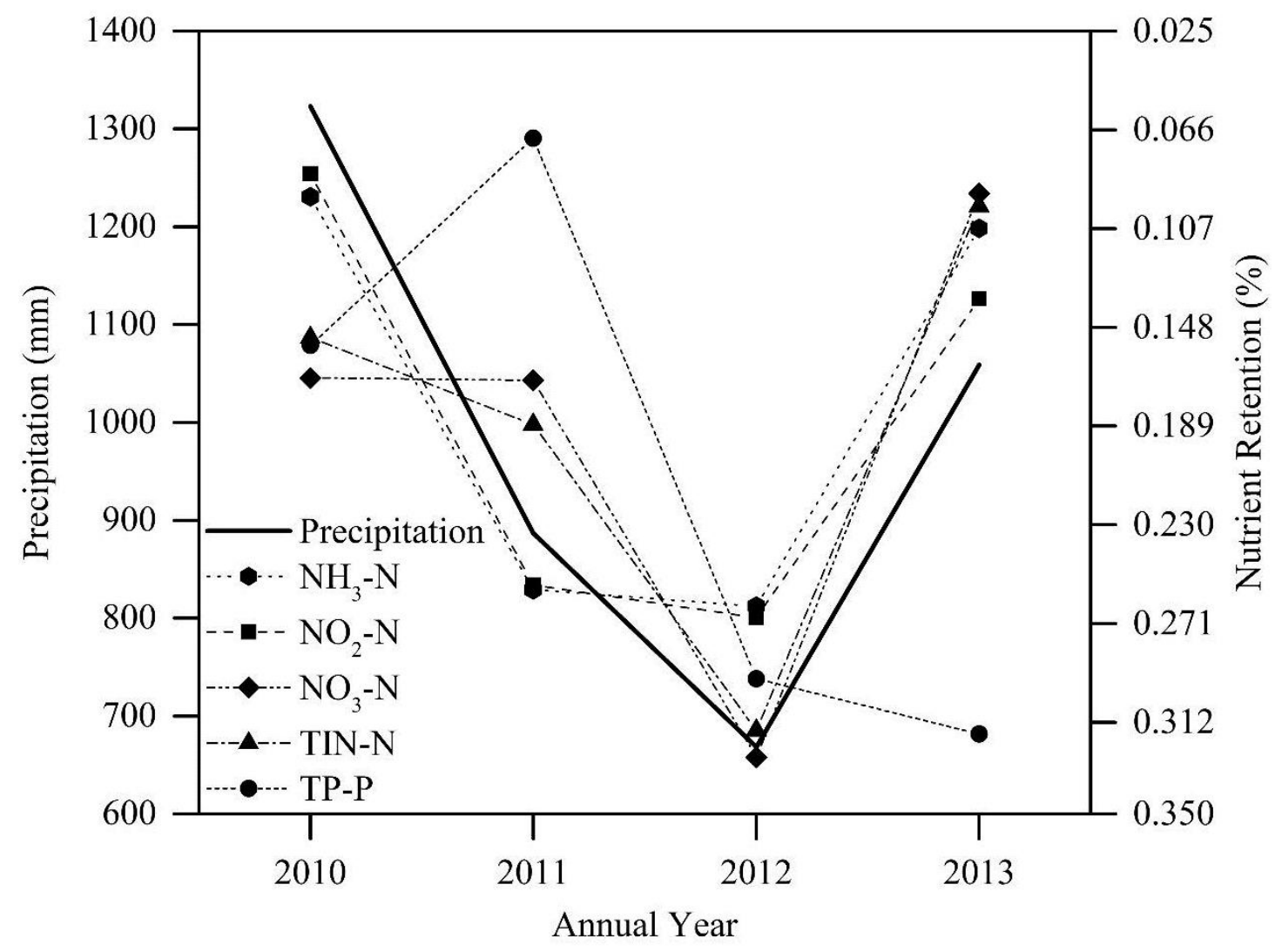

Figure 3.4. Annual total precipitation (solid line) and nutrient retention for each element from 2010 - 2013 measured in Hinkson Creek, Missouri, USA. Nutrient retention was defined as percent difference in annual flow weighted mean nutrient concentration between Site \#1 in the headwaters and Site \#5 near the watershed outlet. $\mathrm{NH}_{3}-\mathrm{N}$ is total ammonia, $\mathrm{NO}_{2}-\mathrm{N}$ is nitrite, $\mathrm{NO}_{3}-\mathrm{N}$ is nitrate, TIN-N is total inorganic nitrogen, and TP-P is total phosphorus.

Seasonal and monthly nutrient levels were obviously affected by the timing of precipitation. Seasonally averaged FWCs were greatest during the $1^{\text {st }}$ and $2^{\text {nd }}$ quarters of the year in agreement from results published by Lerch et al., (2015b) in GCEW. Lerch et al., (2015b) presented quarterly $\mathrm{NO}_{3}-\mathrm{N}$ and $\mathrm{NH}_{3}-\mathrm{N}$ FWCs collected from weir $1\left(72 \mathrm{~km}^{2}\right.$ in drainage size) at GCEW from 1992 to 2010. Quarterly $\mathrm{NO}_{3}-\mathrm{N}$ concentrations (approximately $1.5 \mathrm{mg} \mathrm{L}^{-1}$ ) were slightly greater, while $\mathrm{NH}_{3}-\mathrm{N}$ concentrations (approximately $0.15 \mathrm{mg} \mathrm{L}^{-1}$ ) were lesser in GCEW relative to HCW during the $1^{\text {st }}$ and $2^{\text {nd }}$ quarters. The causes behind the differences in $\mathrm{NH}_{3}-\mathrm{N}$ between GCEW and $\mathrm{HCW}$ are 
presumably attributable to differences in land use practices and annual rainfall/runoff considering the nutrient data from GCEW were collected during 1992 to 2010 and results from the present study were analyzed using data collected from 2010 to 2013.

Monthly average TIN-N and TP-P FWCs were approximately 64\% greater from January to June relative to July through December (Figure 3.5). These results are consistent with results published by Baffaut et al., (2009) for monthly average nutrient loads from GCEW. In the current research, significantly greater $(p<0.007)$ levels of nutrients (percent differences ranged from $45 \%$ for $\mathrm{NH}_{3}-\mathrm{N}$ to $118 \%$ for $\mathrm{NO}_{2}-\mathrm{N}$ ) were observed during the wet season (March through May) compared to the dry season (July through November). Conversely, lesser nutrient levels during July and August may be attributed to increased aquatic plant assimilation and microbial activity when stream temperature and solar radiation rates are generally greatest for the year (Birgand et al., 2007). While nutrient fertilizer inputs were not quantified in this study, early spring and fall fertilizer applications of $\mathrm{N}$ and fall applications of $\mathrm{P}$ are common in the region (Letcher et al., 2015b) and likely contribute to the significantly greater $(p<0.007)$ monthly average nutrient concentrations observed in early spring and late December, especially at agriculture land-use dominated Site \#1. 


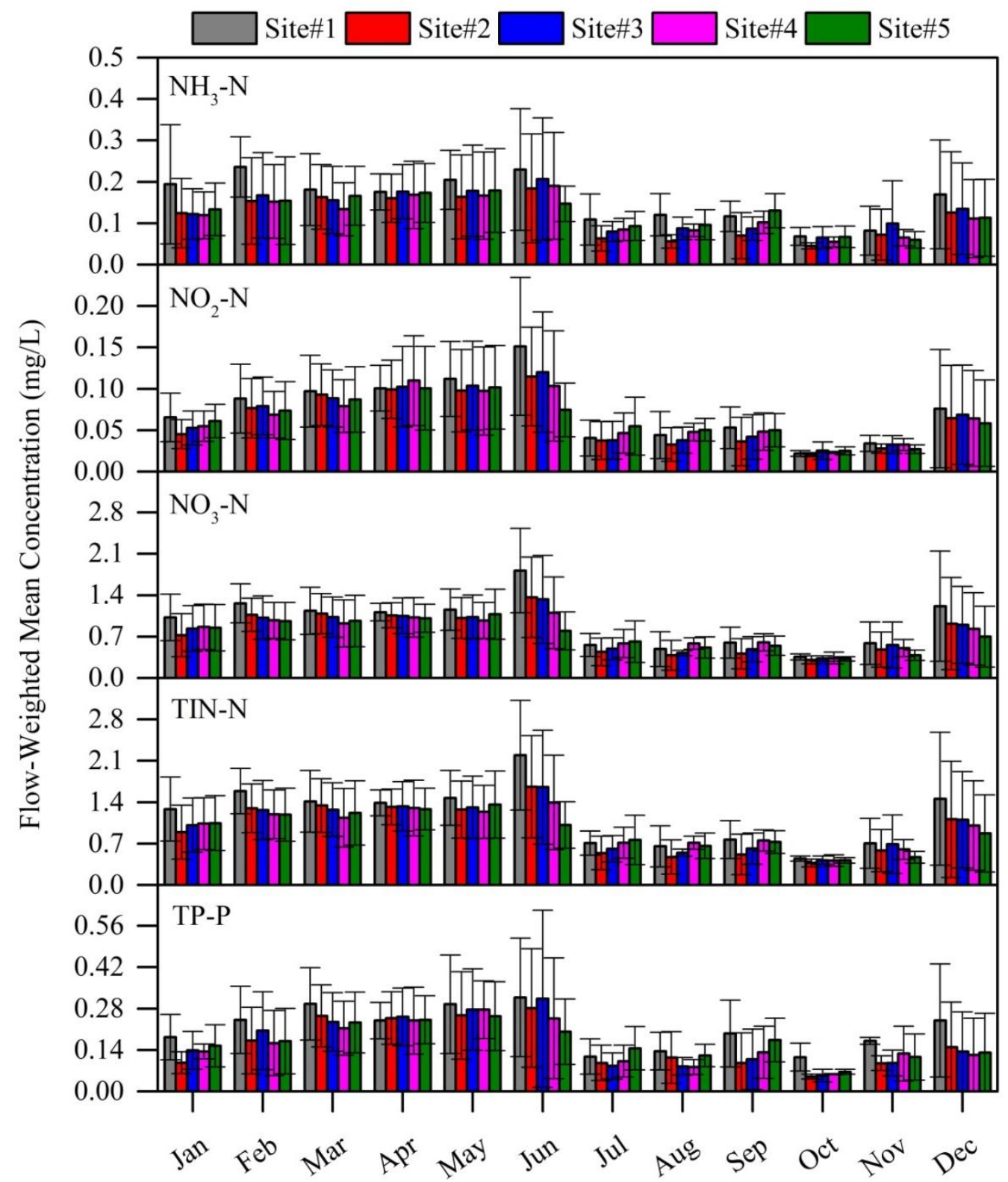

Figure 3.5. Monthly average flow weighted mean nutrient concentrations for each site and each element from 2010 - 2013 measured in Hinkson Creek, Missouri, USA. Error bars show one standard deviation between monthly averages $(n=4) . \mathrm{NH}_{3}-\mathrm{N}$ is total ammonia, $\mathrm{NO}_{2}-\mathrm{N}$ is nitrite, $\mathrm{NO}_{3}-\mathrm{N}$ is nitrate, $\mathrm{TIN}-\mathrm{N}$ is total inorganic nitrogen, and TP-P is total phosphorus.

The nested-scale study design of the current investigation was used to quantify the change in nutrient concentrations and yields with stream distance and land use change. Agricultural land use decreased by $18 \%$ and urban land use increased by $22 \%$ from Site 
\#1 to Site \#5. Average TIN-N and TP-P decreased by $26 \%$ and $36 \%$ from Site \#1 to Site $\# 2$, and increases in urban land use area were in concert with increased $\mathrm{NH}_{3}-\mathrm{N}$ and TP-P levels by $23 \%$ and $15 \%$ between Sites \#2 and \#5 (Table 3.4, Figure 3.6). The differences in maximum $\mathrm{NH}_{3}-\mathrm{N}(80 \%)$ and TP-P (15\%) observed at the urban / rural interface were likely, at least in part, due to legacy sources of $\mathrm{N}$ and P. For example, it is understood that stormwater runoff from urbanization related impervious surfaces can incise stream channels, thereby disturbing entrained $\mathrm{N}$ and $\mathrm{P}$ in stream bed and banks (Bernhardt et al., 2008). Construction sites are also known sources of legacy $\mathrm{N}$ and $\mathrm{P}$ pollution when disturbed soils are transported to receiving water bodies during rainfall/runoff events (Bernhardt et al., 2008). Maximum observed nutrient contributions (e.g. $\mathrm{NH}_{3}-\mathrm{N}=1.5 \mathrm{mg}$ $\mathrm{L}^{-1}$ and $\mathrm{TP}-\mathrm{P}=1.2 \mathrm{mg} \mathrm{L}^{-1}$ ) were greatest at urban Site \#3 where extensive landscaping (e.g. urban parks and homeowner backyards) and impervious surfaces likely contribute to elevated nutrient concentrations and flushing. Landscaping can increase nutrient concentrations when excess lawn fertilizers are transported via surface runoff into nearby urban streams. Walsh et al., (2005) associated urban land use with increased stream nutrient concentrations, differential timing of pollutant delivery, and decreased nutrient retention. Others have corroborated this observation (e.g. Grimm et al., 2005; Meyer et al., 2005; and others). Due to the impacts of landscaping and lawn fertilizers on aquatic ecosystem health, municipalities are increasingly establishing distinct water quality standards (WQS) to control lawn fertilizer loading from residential areas (Lehman et al., 2009). 

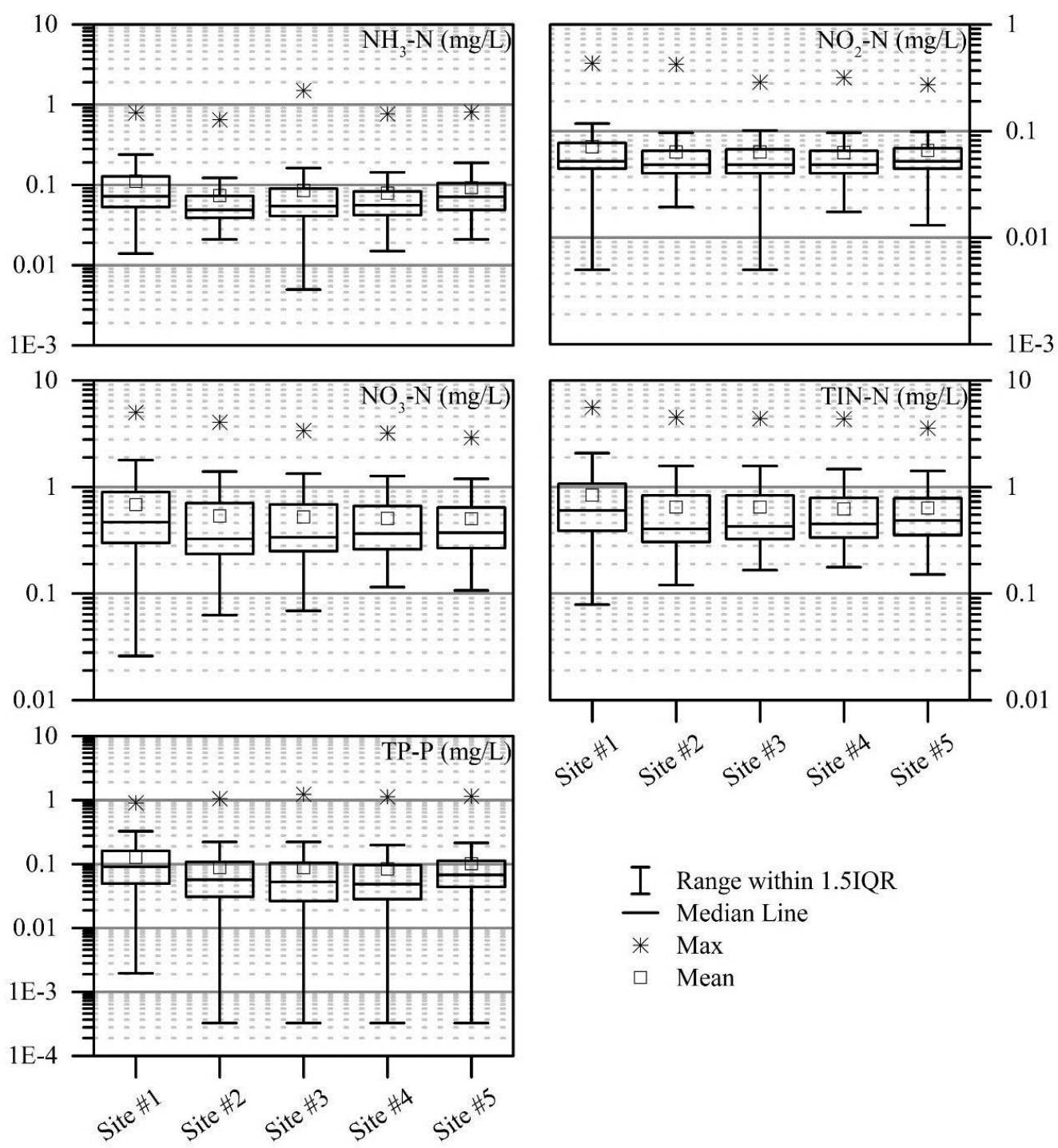

I Range within 1.5IQR

- Median Line

* Max

$\square \quad$ Mean

Figure 3.6. Nutrient concentration descriptive plots ( $n=858$ ) from $2010-2013$ at five gauging sites measured in Hinkson Creek, Missouri, USA. $\mathrm{NH}_{3}-\mathrm{N}$ is total ammonia, $\mathrm{NO}_{2}-\mathrm{N}$ is nitrite, $\mathrm{NO}_{3}-\mathrm{N}$ is nitrate, TIN-N is total inorganic nitrogen, TP-P is total phosphorus, and IQR is interquartile range.

Nutrient levels in the current study were within the range reported by the Central Plains Center for Bioassessment (CPCB, 2002) for 94 reference streams in Oklahoma, Iowa, Nebraska, and Missouri including streams from the same ecoregion as HCW. In comparison to the 94 reference streams of the $\mathrm{CPCB}$, total ammonia levels were in the $90^{\text {th }}$ to $95^{\text {th }}$ percentiles, $\mathrm{NO}_{2}-\mathrm{N}$ levels were greater than the $85^{\text {th }}$ to $95^{\text {th }}$ percentiles, $\mathrm{NO}_{3}-\mathrm{N}$ 
levels were $40^{\text {th }}$ to $50^{\text {th }}$ percentiles, and TP-P levels were in the $50^{\text {th }}$ to $60^{\text {th }}$ percentiles. Nitrate levels were generally greater in the portions of the Iowa where more intensive row cropping agriculture requires increased fertilizer applications that can lead to increased nutrient levels (Birgand et al., 2007). Federal recommended water quality standards (WQS) for stream and river $\mathrm{NH}_{3}-\mathrm{N}$ (ammonia), $\mathrm{NO}_{2}-\mathrm{N}$, and $\mathrm{NO}_{3}-\mathrm{N}$ levels are 17,1 , and $10 \mathrm{mg} \mathrm{L}^{-1}$, respectively (EPA, 2015). These standards can vary among states and regions with changes to $\mathrm{pH}$ and water temperature (EPA, 2015). For example, in Missouri streams and rivers, acute $\mathrm{NH}_{3}-\mathrm{N}$ standards range from 0.8 to $48.8 \mathrm{mg} \mathrm{L}^{-1}$, and chronic (monthly average) $\mathrm{NH}_{3}-\mathrm{N}$ standards range from 0.1 to $10.8 \mathrm{mg} \mathrm{L}^{-1}$ (MDNR, 2014). Inorganic N concentrations did not exceed federal or state WQS in HCW during the study period. However, TP-P was shown to exceed federal WQS of $0.100 \mathrm{mg} \mathrm{L}^{-1}$ (EPA, 1986) at Sites \#3 (1.23 $\left.\mathrm{mg} \mathrm{L}^{-1}\right)$ through \#5 (1.15 mg L $\mathrm{m}^{-1}$ ) (Table 3.4, Figure 3.7). Identifying P polluting sources was beyond the scope of the current work, but these compelling results warrant future investigations. 


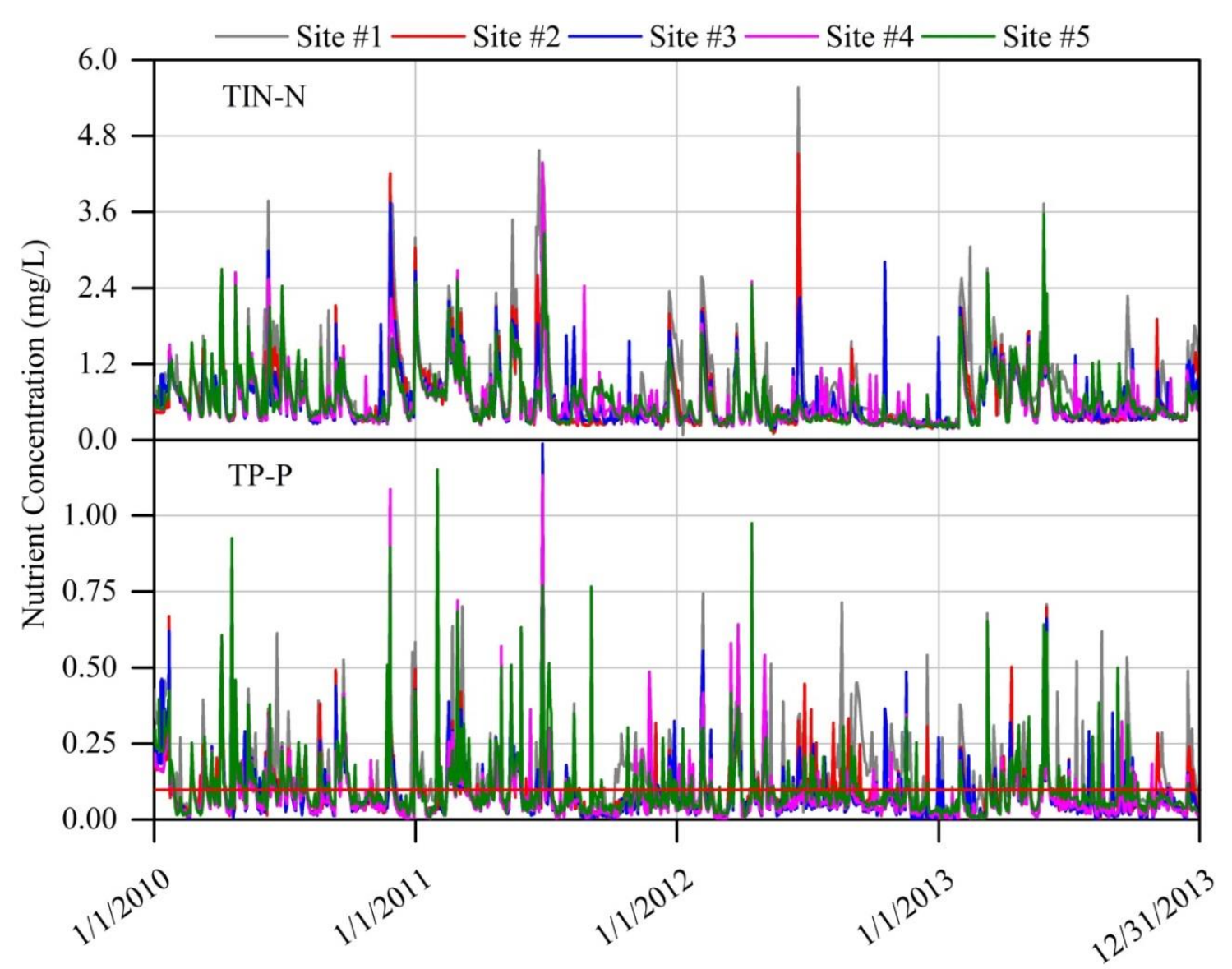

Figure 3.7. Time series nutrient concentrations from 2010 - 2013 at five gauging sites measured in Hinkson Creek, Missouri, USA. TIN-N is total inorganic nitrogen, and TP-P is total phosphorus. The red line shows the $0.10 \mathrm{mg} \mathrm{L}^{-1} \mathrm{TP}-\mathrm{P}$ water quality standard for flowing waters that do not discharge directly into lakes or reservoirs.

Nutrient concentrations and yields in this research were also comparable to a nutrient export study from the nearby Goodwater Creek experimental watershed (GCEW) (Baffaut et al., 2009; Lerch et al., 2015a). Baffaut et al., (2009) analyzed six years (1992 to 1997) of $\mathrm{NH}_{3}-\mathrm{N}$ and $\mathrm{NO}_{3}-\mathrm{N}$ samples collected at stratified time intervals from three weirs with drainage areas of $12 \mathrm{~km}^{2}$ (weir 11), $31 \mathrm{~km}^{2}$ (weir 9), and $73 \mathrm{~km}^{2}$ (weir 1) in size. Daily median $\mathrm{NH}_{3}-\mathrm{N}$ decreased with stream distance, while $\mathrm{NO}_{3}-\mathrm{N}$ concentrations were similar at all sites. For example, $\mathrm{NH}_{3}-\mathrm{N}$ and $\mathrm{NO}_{3}-\mathrm{N}$ ranged from 0.21 and $0.06 \mathrm{mg}$ $\mathrm{L}^{-1}$, and 1.3 to $1.0 \mathrm{mg} \mathrm{L}^{-1}$ at weir 11 and weir 1 , respectively. Thus, daily median $\mathrm{NH}_{3}-\mathrm{N}$ 
and $\mathrm{NO}_{3}-\mathrm{N}$ concentrations were $29 \%$ greater and $70 \%$ lesser, respectively, at $\mathrm{HCW}$ site 1 (79 $\mathrm{km}^{2}$ in drainage size) compared to GCEW weir $1\left(73 \mathrm{~km}^{2}\right.$ in drainage size). Total ammonia yields were approximately $0.180 \mathrm{~kg} \mathrm{ha}^{-1} \mathrm{yr}^{-1}$ greater, while $\mathrm{NO}_{3}-\mathrm{N}$ yields were approximately $2.38 \mathrm{~kg} \mathrm{ha}^{-1} \mathrm{yr}^{-1}$ lesser at agricultural Site \#1 in the current study compared to weir 1 in Baffaut et al., (2009). While quantifying the sources of $\mathrm{NH}_{3}-\mathrm{N}$ was beyond the scope of the current study, a literature review by Bernhardt et al., (2008) showed common sources of $\mathrm{NH}_{3}-\mathrm{N}$ include crop $\mathrm{N}$ fertilizer and livestock in agricultural areas, and wastewater and lawn $\mathrm{N}$ fertilizers in urban areas. Human sewage and wastewater can become problematic inputs of nutrient pollution, especially in watersheds with moderate to high population densities (Cole et al., 1993). Additional work from the GCEW, Lerch et al., (2015b) reported median $\mathrm{NH}_{3}-\mathrm{N}$ and $\mathrm{NO}_{3}-\mathrm{N}$ yields of $0.374 \mathrm{~kg} \mathrm{ha}^{-1}$ $\mathrm{yr}^{-1}$ (approximately $0.5 \mathrm{~kg} \mathrm{ha}^{-1} \mathrm{yr}^{-1}$ less than Site \#1), and $3.65 \mathrm{~kg} \mathrm{ha}^{-1} \mathrm{yr}^{-1}$ (approximately $1.1 \mathrm{~kg} \mathrm{ha}^{-1} \mathrm{yr}^{-1}$ less than Site \#1) from weir 1 during 1992 to 2010. The difference in $\mathrm{NO}_{3}$-N yields published by Baffaut et al., (2009) and Lerch et al., (2015b) supports the effects of changes in fertilizer applications and the inclusions of BMPs in GCEW. Total inorganic nitrogen yield in $\mathrm{HCW}$ was $28 \%$ greater than average TN-N yield from North America to the North Atlantic Ocean $\left(4.04 \mathrm{~kg} \mathrm{ha}^{-1} \mathrm{yr}^{-1}\right)$, and 5\% less than TN-N yield from the Mississippi River Basin (MRB) at the mouth of the Mississippi River to the Gulf of Mexico (5.63 $\mathrm{kg} \mathrm{ha}^{-1} \mathrm{yr}^{-1}$ ) (Howarth et al., 1996). TP-P yield in HCW was $2 \%$ greater than average TP-P export from North America to the North Atlantic Ocean (0.96 $\left.\mathrm{kg} \mathrm{ha}^{-1} \mathrm{yr}^{-1}\right)$, and 52\% less than average TP-P yield from the MRB $\left(1.67 \mathrm{~kg} \mathrm{ha}^{-1} \mathrm{yr}^{-1}\right)$ (Howarth et al., 1996). Total phosphorus yield from HCW was in the $80^{\text {th }}$ percentile of the Upper MRB (Robertson and Saad, 2011). Lerch et al., (2015b) showed the relatively 
large dissolved phosphorus yields observed in GWEW were due to excessive runoff and erosion that has been associated with claypan soils in the region, which may indicate why HCW also has increased runoff rates and TP-P yields.

\section{Study Implications}

In this research, multiple methods commonly used to calculate nutrient loading were tested using a rigorous data set that included wet, dry and average years, thus informing of method(s) reliability. Results highlight the need for sampling durations that encompass wet, dry, and average years to generate accurate estimates of annual nutrient yields considering the strong relationship between annual total precipitation and nutrient

yields. For example, differences in annual total precipitation $(639 \mathrm{~mm}$ to $1342 \mathrm{~mm})$ led to percent differences in nutrient yields ranging from 115 to $172 \%$. Estimates of nutrient yield would have been over- or under-estimated using only data collect during 2010 (wet year), or 2012 (year of drought), respectively. Authors from other studies (Walling and Webb 1981; Letcher et al., 1999; Quilbe et al., 2006) have stressed the need for adequate sampling intensity to generate accurate pollutant load estimates. Information generated from this work is therefore all the more telling given the climate variability during the study. Method 1 (linear interpolation) resulted in the most reliable load estimates. This may have been somewhat expected given the rich observed data set and since linear interpolation methods can be used to accurately estimate pollutant load when the sampling frequency captures the variability in nutrient concentration with streamflow (Quilbe et al., 2006), such as in the current four-year study ( $n=858$ sample days per site). Walling and Webb (1981) and Letcher et al., (1999) reviewed techniques to estimate loading results showing that Method 2 (Average sample load) generally resulted 
in a more accurate load estimate compared to Method 3 (Average sample concentration $\mathrm{x}$ average sample discharge) because Method 2 weights nutrient concentrations to flow at the time of sampling. However, Method 3 has been shown to result in worthwhile estimates suitable for the relative ranking for pollutant loads using data collected at monthly sampling intervals (Walling and Webb, 1981; Letcher et al., 1999).

The nutrient rating curves presented in Figure 3.2 and the multiple regression equations presented in Table 3.6 may be used for nutrient predictions in nearby watersheds with similar climate, slope, roughness, soils, karst influence, vegetation, and land use practices. In agreement to other studies (Vieux and Moreda, 2003; Quilbe et al., 2006), results from this research showed that Method 4 (rating curve) performance was satisfactory (NSE values greater than 0.50) for TP-P load estimates, as might be expected considering P settling and adsorption processes. The rating method has been shown to underestimate loads during peak streamflow periods when the majority of pollutants are transported, and overestimate loads during periods of low flow (Walling and Webb, 1981; Quilbe et al., 2006). However, when the sampling regimen captures enough of the variability of pollutant load, rating curves have been shown to result in accurate estimates of pollutant load. Using discharge as an independent variable improved $R^{2}$ values in log space discharge-loading regression relationships in the current work. However, when nutrient rating curves were validated using one year (2013) of measured data, results showed the empirical technique worked well considering NSE values greater than 0.50 , RSR values less than 0.70 . PBIAS values $\leq \pm 70$ are considered to be satisfactory for nutrient loading estimates at a monthly time step (Moriasi et al., 2007). While all of the algorithms tested at least good relative to the modeling guidelines proposed by Moriasi et 
al., (2007), caution should be used when relying on loading estimates generated using rating curves in terms of transferability to other watersheds (Walling and Webb, 1988).

Few data sets are available at nested-scales in rapidly urbanizing watersheds where a patch-work of mixed-land use types can confound classic nutrient export assumptions. The nested-scale experimental study design used in this research will help target critical source areas to implement better management practices. The results are useful for future testing of hydrologic models considering the spatial and temporal resolution of the data set and the inclusion of record setting wet and drought years. Model evaluation results will aid the testing and development of improved models designed to predict complex interactions of climate change, land use change, and management practices in urbanizing watersheds. Given the value of the study and related datasets, HCW serves as a model for managers of mixed-land use watersheds seeking methods to monitor and quantitatively characterize nutrient sources and yields.

\section{Conclusions}

Quantification of $\mathrm{N}$ and $\mathrm{P}$ yield is essential for improved application of best management practices. However, problems associated with spatial complexity (i.e. multiple land-use types) and scaling complicate attempts to quantify nutrient yields. Hence, there is an ongoing need for long-term mixed-land use watershed scale monitoring of nutrient yields. Nutrient concentrations were monitored for four years (2010 - 2013) using a five-site nested-scale experimental watershed study design. Agricultural land use decreased as urban land use increased with stream distance. Average observed nutrient concentrations were $20 \%$ to $44 \%$ greater at Site \#1 (nearest

the headwaters) where agricultural land use was $58 \%$ of the total drainage area $\left(79 \mathrm{~km}^{2}\right)$. 
Maximum $\mathrm{NH}_{3}-\mathrm{N}$ concentrations exceeded $1.50 \mathrm{mg} \mathrm{L}^{-1}$ at the urban / rural interface of the watershed (Site \#3). Maximum TP-P concentrations exceeded $1.00 \mathrm{mg} \mathrm{L}^{-1}$ at Sites \#3 (1.23 $\left.\mathrm{mg} \mathrm{L}^{-1}\right)$ to \#5 $\left(1.15 \mathrm{mg} \mathrm{L}^{-1}\right)$ where urban land use was greater than $13 \%$ of total drainage area. Overall, $\mathrm{NO}_{3}-\mathrm{N}$ export $\left(4.24 \mathrm{~kg} \mathrm{ha}^{-1} \mathrm{yr}^{-1}\right)$ observed near the watershed outlet (Site \#5) was relatively low compared to other watersheds in the Mid-West, but $\mathrm{NH}_{3}-\mathrm{N}$ yields $\left(0.742 \mathrm{~kg} \mathrm{ha}^{-1} \mathrm{yr}^{-1}\right)$ and TP-P yields $\left(0.979 \mathrm{~kg} \mathrm{ha}^{-1} \mathrm{yr}^{-1}\right)$ were large for the region. Increased levels of $\mathrm{NH}_{3}-\mathrm{N}$ observed in $\mathrm{HCW}$ were likely attributed to a combination of crop $\mathrm{N}$ fertilizer and livestock in the agricultural areas, and wastewater and lawn $\mathrm{N}$ fertilizers in urban areas. Other regional studies indicate the relatively large TP-P yields may be at least in part attributable to excessive runoff and erosion that is associated with claypan soils and increased impervious surfaces, as well as urban land and yard-scaping practices. Results from the current study highlight the importance of sampling durations that encompass wet, dry, and average years to generate accurate estimates of average annual nutrient yields. This work supplies critically needed results, methodology, and improved understanding of nutrient yield in contemporary mixed-landuse watersheds and highlights the need for innovative approaches in urbanizing watersheds to reduce nutrient export from especially considering expected future trends in urban growth and climate change.

\section{Acknowledgements}

Funding was provided by the Missouri Department of Conservation and the U.S. Environmental Protection Agency Region 7 through the Missouri Department of Natural Resources (P.N: G08-NPS-17) under Section 319 of the Clean Water Act. Results presented may not reflect the views of the sponsors and no official endorsement should 
be inferred. Collaborators include (but are not limited to) Boone County Public Works, City of Columbia, University of Missouri, and the U.S. Geological Survey. Special thanks are due to John Schulz, scientists of the University of Missouri Interdisciplinary Hydrology Laboratory, and constructive comments of multiple reviewers that improved the article. 


\section{Literature Cited}

Alexander RB, Smith RA, Schwarz GE, Boyer EW, Nolan JV, Brakebill JW . 2008. Differences in phosphorous and nitrogen delivery to the Gulf of Mexico from the Mississippi River Basin. Environmental Science Technology, 42: 822-830.

Arnold JG, Allen PM. 1999. Automated methods for estimating base flow and ground water recharge from streamflow records. JAWRA, 35(3): 411-424.

Baffaut, C., E.J. Sadler, and F. Ghidey. 2015. Long-term agroecosystem research in the Central Mississippi River Basin: Goodwater Creek Experimental Watershed flow data. Journal of Environmental Quality, 44:17-26. doi:10.2134/jeq2014.01.0008

Baffaut, C., E.J. Sadler, R.N. Lerch, and N.R. Kitchen. 2009. Nutrient sources and transport from the Goodwater Creek Experimental Watershed. Pap. 097150. Transactions of the ABASE, St. Joseph, MI.

Bolstad, P.V., Swank, W.T., 1997. Cumulative impacts of land use on water quality in a Southern Appalachian watershed. JAWRA, 33: 519-533.

Battaglin WA, Kendall C, Chang CCY, Silva SR, and Campbell DH. 2001. Chemical and isotopic evidence of nitrogen transformation in the Mississippi River, 1997-98. Hydrological Processes, 15: 1285-1300.

Bernhardt ES, Band LE, Walsh CJ, Berke PE. 2008. Understanding, managing, and minimizing urban impacts on surface water flux. Annals of the New York Academy of Sciences, 1134: 61-96.

Birgand F, Skaggs RW, Chescheir GM, Gilliam JW. 2007. Nitrogen removal in streams of agricultural catchments - a literature review. Critical Reviews in Environmental Science and Technology, 37: 381-487.

Carpenter SR, Caraco NF, Correll DL, Howarth RW, Sharpley AN, Smith VH. 1998. Nonpoint pollution of surface waters with phosphorus and nitrogen. Ecological Applications, 8: 559-568.

Central Plains Center for Bioassessment. 2002. Nutrient Streams Project. [Database.] Kansas Biol. Surv., Lawrence. http://cpcb.ku.edu/resources/databases/.

Chang C-H, Wen C-G, Huang C-H, Change S-P, Lee C-S. 2008. Nonpoint source pollution loading yield from an undistributed tropic forest area. Environmental monitoring and assessment, 146(1-3): 113-126.

Clark GM, Mueller DK, Mast MA. 2000. Nutrient concentrations and yields in undeveloped stream basins of the United States. JAWRA, 36(4): 849-860. 
Cole JJ, Peierls BL, Caraco NF, Pace ML. 1993. Nitrogen loading of rivers as a humandriven process. In: McDonnell MJ \& Pickett STA (Eds) Humans as Components of Ecosystems: The Ecology of Subtle Human Effects and Populated Areas (pp 141-157). Springer-Verlag, New York, NY

Environmental Protection Agency (EPA). 1986. Quality criteria for water 1986. Available online http://water.epa.gov/scitech/swguidance/standards/criteria/aqlife/upload/2009_01 _13_criteria_goldbook.pdf

Environmental Protection Agency (EPA). 2015. National Recommended Water Quality Criteria for water 1986. Available online http://water.epa.gov/scitech/swguidance/standards/criteria/current/index.cfm\#hhta ble

Floyd WC, Schoenholtz SH, Griffith SM, Wigington PJ, Steiner JJ. 2009. Nitratenitrogen, land use/land cover, and soil drainage associations at multiple spatial scales. Journal of Environmental Quality, 38:1473-1482.

Grimm NB, Sheibly RW, Crenshaw CL, Dahm CN, Roach WJ, Zeglin LH. 2005. N retention and transformation in urban streams. Journal of the North American Benthological Society, 24:626-642.

Groffman PM, Law NL, Belt KT, Band LE, Fisher GT. 2004. Nitrogen fluxes and retention in urban watershed ecosystems. Ecosystems, 7: 393-403.

Howarth RW, Billen G, Swaney D, Townsend A, Jaworski N, Lajtha K, Downing JA, Elmgren R, Caraco T, Jordan T, Berendse F, Freney J, Kudeyarov V, Murdoch P, Zhu ZL. 1996. Regional nitrogen budgets and riverine N \& P fluxes for the drainages to the North Atlantic Ocean: Natural and human influences. Biochemistry, 35(1): 75-139.

Hubbart JA, and Zell C. 2013. Considering streamflow trend analyses uncertainty in urbanizing watersheds: a base flow case study in the central United States. Earth Interactions, 17(5): 1-28.

Hubbart JA, Kellner E, Freeman G. 2013. A case study considering the comparability of mass and volumetric suspended sediment data. Environmental Earth Science, 71(9): 4051-4060.

Hubbart JA, Holmes J, Bowman G. 2010. Integrating science based decision making and TMDL allocations in urbanizing watersheds. The Watershed Science Bulletin, 01: 19-24. 
Hubbart JA, Kellner E, Lynne H, Lupo AR, market PS, Guinan PE, Stephan K, Fox NI, Svoma, BM. 2014. Localized climate and surface energy flux alterations across an urban gradient in the central US. Energies, 7: 1770-1791.

Jordan TE, Correll DL, Weller, DE. 1997. Relating nutrient discharges from watersheds to land use and streamflow variability. Water Resources Research, 33: 25792590.

Kaushal SS, Groffman PM, Band LE, Shields CA, Morgan RP, Palmer MA, Belt KT, Swan CM, Findlay SEG, Fisher GT. 2008. Interaction between Urbanization and Climate Variability Amplifies Watershed Nitrate Export in Maryland. Environmental Science \& Technology, 42(16): 5872-5878.

Lehman JT, Bell DW, McDonald KE. 2009. Reduced river phosphorus following implementation of a lawn fertilizer ordinance. Lake and Reservoir Management, 25: 307-312.

Lerch RN, Kitchen NR, Baffaut C, Vories ED. 2015a. Long-term agroecosystem research in the Central Mississippi River Basin: Goodwater Creek Experimental Watershed and regional nutrient water quality data. Journal of Environmental Quality, 44: 37-43.

Lerch RN, Baffaut C, Kitchen NR, Sadler EJ. 2015b. Long-term agroecosystem research in the Central Mississippi River Basin: Dissolved nitrogen and phosphorus transport in a high-runoff-potential watershed. Journal of Environmental Quality, 44: 44-57.

Letcher RA, Jakeman AJ, Merritt WS, McKee LJ, Eyre BD, Baginska B. 1999. Review of Techniques to Estimate Catchment Exports, Environment Protection Authority, Sydney.

Lewis DB, Grimm NB. 2007. Hierarchical regulation of nitrogen export from urban catchments: Interactions of storms and landscapes. Ecological Applications, 17(8): 2347-2364.

MDNR. 2006. Stream Survey Sampling Report. Phase III Hinkson Creek Stream Study, Columbia, Missouri, Boone County. Prepared by the Missouri Department of Natural Resources, Field Services Division, Environmental Services Program, Water Quality Monitoring Section.

Missouri Department of Natural Resources (MDNR). 2014. Rules of Department of Natural Resources Division 20-Clean water Commission Chapter 7-Water Quality. https://www.sos.mo.gov/adrules/csr/current/10csr/10c20-7a.pdf 
Moriasi DN, Arnold JG, Van Liew MW, Bingner RL, Harmel RD, Veith TL. 2007. Model evaluation guidelines for systematic quantification of accuracy in watershed simulations. Transactions of the ASABE, 50(3): 885-900.

Mueller DK. Helsel DR. 2013. Nutrients in the Nation's Waters-Too much of a good thing? National Water-Quality Assessment (NAWQA) Program. Circ 1136. http://pubs.usgs.gov/circ/circ1136/

NOAA National Climatic Data Center, State of the Climate: Drought for Annual 2012, published online December 2012, retrieved on July 10, 2014 from http://www.ncdc.noaa.gov/sotc/drought/2012/13.

Palmer MA, Reidy C, Nilsson C, Florke M, Alcamo J, Lake PS, Bond N. 2008. Climate change and the world's river basins: Anticipating management options. Frontiers Ecol. Environ., 6 (2): 81-89.

Poor CJ, McDonnell JJ. 2007. The effects of land use on stream nitrate dynamics. Journal of Hydrology, 332(1-2): 54-68.

Quilbe R, Rousseau AN, Duchemin M, Poulin A, Gangbazo G, Villeneuve JP. 2006. Selecting a calculation method to estimate sediment and nutrient loads in streams: application to the Beaurivage River (Quebec, Canada). Journal of Hydrology, 326(1-4): 295-310.

Rabalais NN, Turner RE, Wiseman WJ. 2002. Gulf of Mexico hypoxia, a.k.a. "The Dead Zone". Annual Review of Ecology and Systematics, 33: 235-263.

Robertson DM, Saad DA. 2011. Nutrient inputs to the Laurentian Great Lakes by source and watershed estimated using SPARROW watershed models. JAWRA, 47: 10111033.

Royer TV, David MB, Gentry LE. 2006. Timing of riverine export of nitrate and phosphorus from agricultural watersheds in Illinois: Implications for reducing nutrient loading to the Mississippi River. Environmental Science \& Technology, 40: 4126-4131.

Sadler JE, Lerch RN, Kitchen NR, Anderson SH, Baffaut C, Sudduth KA, Prato AA, Kremer RJ, Vories ED, Myers DB, Broz R, Miles RJ, Young FJ. 2015. Long-term agroecosystem research in the Central Mississippi River Basin: Introduction, establishment, and overview. Journal of Environmental Quality, 44: 3-12.

Salvia-Castellvi M, Iffly JF, Borght PV, Hoffman L. 2005. Dissolved and particulate nutrient export from rural catchments: a case study from Luxembourg. Science of the Total Environment, 344: 51-65. 
Sator JD, Boyd GB, Agardy FJ. 1974. Water Pollution Aspects of Street Surface Contaminants. Water Pollution Control Federation, 46(3): 458-467.

Shields CA, Band LE, Law N, Groffman PM, Kaushal SS, Savvas K, Fisher GT, Belt KT. 2008. Streamflow distribution of non-point source nitrogen export from urban-rural catchments in the Chesapeake Bay watershed. Water Resources Research, 44: W09416

Turner RE. Rabalais NN. 2004. Suspended sediment, C, N, P and Si yields from the Mississippi River Basin. Hydrobiologia, 511: 79-89.

United States Census Bureau (USCB). 2012. U.S. Census Bureau: State and County Quick Facts. Available on line at: http://quickfacts.census.gov/qfd/states/29000.html

Vieux, B.E., Moreda, F.G., 2003. Nutrient loading assessment in the Illinois River using a synthetic approach. JAWRA, 39 (4), 757-769.

Walling DE, Webb BW. 1988. Reliability of rating curve estimates of suspended sediment yield: some further comments. In Bordas NP. Walling DE. (eds.). Sediment budgets. Proceedings of the Porto Alegre Symposium, IAHS Publication, 174: 337-350.

Walling D, Webb B. 1981. The reliability of suspended sediment load data. Erosion and Sediment Transport Measurement. IAHS Publication, 133: 177-194.

Walsh CJ, Roy AH, Feminella JW, Cottingham PD, Groffman PM, Morgan II RP. 2005. The urban stream syndrome: current knowledge and the search for a cure. Journal of the North American Benthological Society, 24(3): 706-723.

Wollheim WM, Pellerin BA, Vorosmarty CJ, Hopkinson CS. 2005. N retention in urbanizing headwater catchments. Ecosystems, 8: 871-884.

Zhou B, He HS, Nigh TA, Schulz JH. 2012. Mapping and analyzing change of impervious surface for two decades using multi-temporal Landsat imagery in Missouri. International Journal of Applied Earth Observation and Geoinformation, 18: 195-206. 


\title{
CHAPTER IV
}

NESTED-SCALE SWAT MODEL ESTIMATIONS OF STREAM FLOW, SEDIMENT

AND NUTRIENTS FROM A MIXED-LAND USE WATERSHED OF THE CENTRAL

USA

In Revision:

Zeiger, S., and J.A. Hubbart. 2016. Nested-scale SWAT model estimations of stream flow, sediment and nutrients from a mixed-land use watershed of the central USA. Science of the Total Environment. $\mathrm{x}: \mathrm{xx}$.

\begin{abstract}
There is an ongoing need to validate the accuracy of predictive model simulated pollutant yields, particularly from multiple-land-use (i.e. forested, agricultural, and urban) watersheds. However, there are seldom sufficient observed data sets available that supply requisite spatial and temporal resolution and coupled multi-parameter constituents for rigorous model performance assessment. Four years of hydroclimate and water quality data were used to validate SWAT model estimates of monthly stream flow, sediment, total phosphorus, nitrate, nitrite, ammonium, and total inorganic nitrogen from 5 nestedscale gauging sites located in a multiple-land-use watershed of the central USA. The uncalibrated SWAT model satisfactorily simulated monthly stream flow with NashSutcliffe efficiency (NSE) values ranging from 0.50 near the headwaters, to 0.75 near the watershed outlet. However, the uncalibrated model did not accurately simulate monthly sediment, total phosphorus, nitrate, nitrite, ammonium, and total inorganic nitrogen with NSE values less than 0.05. Calibrating the SWAT model to multiple gauging sites within
\end{abstract}


the watershed improved estimates of monthly stream flow (NSE=0.83), sediment (NSE=0.78), total phosphorus (NSE=0.81), nitrate $(\mathrm{NSE}=0.90)$, and total inorganic nitrogen $(\mathrm{NSE}=0.86)$. However, NSE values were less than -0.16 for nitrite and ammonium estimates. Additionally, model performance decreased for sediment, nitrate, and total inorganic nitrogen during the validation period with NSE values less than 0.62 , 0.52 , and 0.36 , respectively. Results highlight the benefits of calibrating the SWAT model to multiple gauging sites and provide guidance to SWAT model (or similar models) users wishing to improve model performance at multiple scales.

\section{Introduction}

Continuous physically-based watershed-scale hydrologic models are an attractive choice for engineers, scientists, and managers that need estimates of the long-term effects of climate and land management practices on water and nonpoint-source pollutant yields without substantial investments of time and money (Borah et al., 2006). While there are several long-term continuous models to choose from, the Soil and Water Assessment Tool (SWAT) is a popular choice for many applications including, but not limited to, pollutant loading estimates, receiving water quality, source load allocation determinations, and conservation practice efficacy (Borah et al., 2006; Gassman et al., 2007). A complete description of the SWAT model can be found in Soil and Water Assessment Tool Theoretical Documentation published by Neitsch et al., (2009), and literature reviews by Borah et al., (2006) and Gassman et al., (2007) who discussed various strengths and weaknesses of the model through performance evaluations. Borah and Bera, (2003) showed the SWAT model has particular strengths in simulating agricultural and agrochemical management practices. However, the model has been 
shown to underestimate peak flows during extreme events (Borah et al., 2006). Problems with flow, sediment and chemical routing algorithms have also been reported (Gassman et al., 2007; Borah et al., 2006). For example, SWAT parameterizations do not include spatial distribution of precipitation and pollutants when routing of flow and nonpointsource pollution. Model testing and development has helped make the SWAT model more useful, but there remains a need for further model evaluation, calibration and validation (Borah and Bera, 2003; Moriasi et al., 2007), especially for ungauged evaluations (Srinivasan et al., 2010).

The SWAT model is equipped to estimate hydrologic, sediment, and chemical yields in ungauged watersheds (Srinivasan et al., 2010). However, there is a need to validate the SWAT model using long-term multi-constituent data sets to improve model reliability in ungagged basins. To reduce uncertainty and model error, the typical SWAT project involves model calibration and validation using observed data collected at the watershed outlet (Gassman et al., 2007). However, while the model can be satisfactorily calibrated and validated at the watershed outlet, it may still be associated with low model performance at upstream reaches (Zhang et al., 2008; Srinivasan et al., 2010). Model performance assessment using data collected at nested-scales can help to achieve satisfactory model performance throughout the entire watershed, but those data are seldom available. Additionally, application of an experimental watershed study design can partition a multiple-land use watershed into sub-basins each with different dominant land uses, thereby decoupling synergistic and often confounding impacts of multipleland-use practices on hydrologic and nonpoint-source pollutant yields (Hubbart et al., 2010). Such an approach to model performance assessment is critical considering money, 
time and other resources can be wasted on mitigation actions based on inaccurate and potentially unrealistic model generated waste load allocations.

While the SWAT model has been extensively evaluated, calibrated and validated with regards to stream flow, literature pertaining to the accuracy of sediment simulations (Borah and Bera, 2003), and nutrient simulations (total phosphorus (TP-P), and nitrogen), are rare (Moriasi et al., 2007). This is particularly true for inorganic forms of nitrogen [nitrate $\left(\mathrm{NO}_{3}-\mathrm{N}\right)$, nitrite $\left(\mathrm{NO}_{2}-\mathrm{N}\right)$, and ammonium $\left(\mathrm{NH}_{4}-\mathrm{N}\right)$ ] (Lee et al., 2010; Lam et al., 2010, Akhavan et al., 2010, Du et al., 2006). Additionally, there is a lack of studies that combine all of the aforementioned hydrologic and water quality variables simultaneously. The lack of studies is primarily due to the scarcity of long-term, in-situ, high-resolution hydrologic and water quality data sets, especially sediment and agrochemical data (Borah and Bera, 2003). Further, few authors applied an experimental watershed study design approach to assess model performance, the outcomes of which would greatly increase end-user confidence in the model, and more aptly guide practices, policy and model improvements. Given the need for such work, the objectives of the current work were to validate SWAT model concurrent estimations (ungauged and calibrated) of monthly i) stream flow, ii) sediment, iii) TP-P, iv) $\mathrm{NO}_{3}-\mathrm{N}$, v) $\mathrm{NO}_{2}-\mathrm{N}$, vi) $\mathrm{NH}_{4}-\mathrm{N}$, and vii) total inorganic nitrogen using four-years of observed data collected using a nested-scale experimental watershed study design in a multiple-land-use urbanizing watershed of the central USA. 


\section{Methods}

Study Area

Hinkson Creek Watershed (HCW) is an urbanizing multiple-land-use (i.e. 33\%

forested, 38\% agricultural, and 26\% urban) watershed located in central Missouri (Table 4.1, Figure 4.1). At the time of this study, forested land cover was oak-hickory dominated, agricultural land use was primarily grazing pasture, and urban land use was mainly residential in HCW. Approximately $28 \mathrm{~km}^{2}$ of impervious surfaces were located within the municipal boundary of the City of Columbia (population 113,225; USCB, 2014; Hubbart et al., 2014). The drainage area of HCW is approximately $230 \mathrm{~km}^{2}$ with elevation range of $177 \mathrm{~m}$ to $274 \mathrm{~m}$ above mean sea level (AMSL) from the outlet to the headwaters, respectively.

Soils in HCW are comprised of the Weller-Bardley-Clinkenbeard (CBC) association and are underlain by Pennsylvanian sandstone and Burlington formation Mississippian series limestone (Miller and Vandike 1997; Hubbart and Zell, 2013). Upland soils corresponding to the Mexico-Leonard association are generally poorly to moderately drained loamy loess with a well-developed underling claypan of smectitic minerals in the argillic horizon (Hubbart and Zell, 2013). Claypan soils in HCW are associated with increased surface runoff potential (hydrologic groups C and D) with infiltration rates as low as $0.001 \mathrm{~cm} \mathrm{hr}^{-1}$ (Blanco et al., 2002), while infiltration rates of $126.0 \mathrm{~cm} \mathrm{hr}^{-1}$ were observed in alluvial soils at woody lowland sites (Hubbart et al., 2011).

The 30-year average (1981-2010) annual total precipitation was of $1176 \mathrm{~mm}$, with mean air temperature of $13.3^{\circ} \mathrm{C}$ observed at Sanborn Field climate station located on 
University of Missouri campus (Figure 4.1) (Hubbart et al. 2014). In the winter, atmospheric conditions are dominated by continental polar air masses. Snowfall is common during winter months when polar air masses meet warm moist air from the Gulf of Mexico. Soils and underlying bedrock are subject to freeze-thaw conditions that have long been known to increase erosion rates (Leopold et al., 1964). Air temperatures range from $-23.1{ }^{\circ} \mathrm{C}$ to $41.3{ }^{\circ} \mathrm{C}$ in the winter and summer, respectively. Summertime weather is controlled mainly by maritime and continental tropical air masses. A wet season occurs primarily during March through June (Hubbart et al., 2010, Hubbart et al., 2014).

Hinkson Creek, the main channel of HCW, is primarily storm flow dominated with a base flow index ranging from 0.17 in the headwaters to 0.27 near the watershed outlet (Zeiger and Hubbart, 2015a). Hinkson Creek was instrumented with a nested-scale experimental watershed study design during winter 2008 where hydroclimate gauging sites $(n=5)$ partitioned the catchment into five sub-basins, each with different dominant land uses (Hubbart et al., 2010). Site \#5 is located near the watershed outlet, and Sites \#1 to \#4 are nested within (Figure 4.1). Site \#4 is a U.S. Geological Survey site (USGS 06910230) where stage and discharge has been intermittently monitored since 1967. 
Table 4.1. Cumulative drainage area, land use and land cover area to each gauging site located in Hinkson Creek Watershed (HCW), Missouri, USA. "HCW" is cumulative of Sites \#1 through \#5.

\begin{tabular}{lcccccc}
\hline LULC (ha) & Site \#1 & Site \#2 & Site \#3 & Site \#4 & Site \#5 & HCW \\
\hline Open water & 38.5 & 53.3 & 58.1 & 109.0 & 135.0 & 146.0 \\
Residential & 355.5 & 536.6 & 1027.5 & 2430.3 & 3726.9 & 4623.2 \\
Urban & 4.9 & 91.0 & 442.8 & 1242.3 & 1716.2 & 2103.8 \\
Barren & 1.3 & 29.0 & 30.9 & 41.0 & 41.5 & 42.0 \\
Forested & 2842.8 & 3754.3 & 4109.2 & 6276.4 & 6863.5 & 7485.6 \\
Grassland & 88.3 & 105.6 & 109.4 & 166.9 & 178.1 & 194.0 \\
Grazing pasture & 3533.0 & 4358.3 & 4438.0 & 6021.2 & 6106.5 & 6604.5 \\
Row crop & 879.2 & 1168.7 & 1209.2 & 1660.6 & 1682.2 & 1743.3 \\
Wetland & 152.4 & 188.2 & 194.0 & 251.5 & 300.4 & 341.2 \\
Area & 7895.9 & 10284.8 & 11618.9 & 18199.1 & 20750.3 & 23283.6 \\
\hline
\end{tabular}




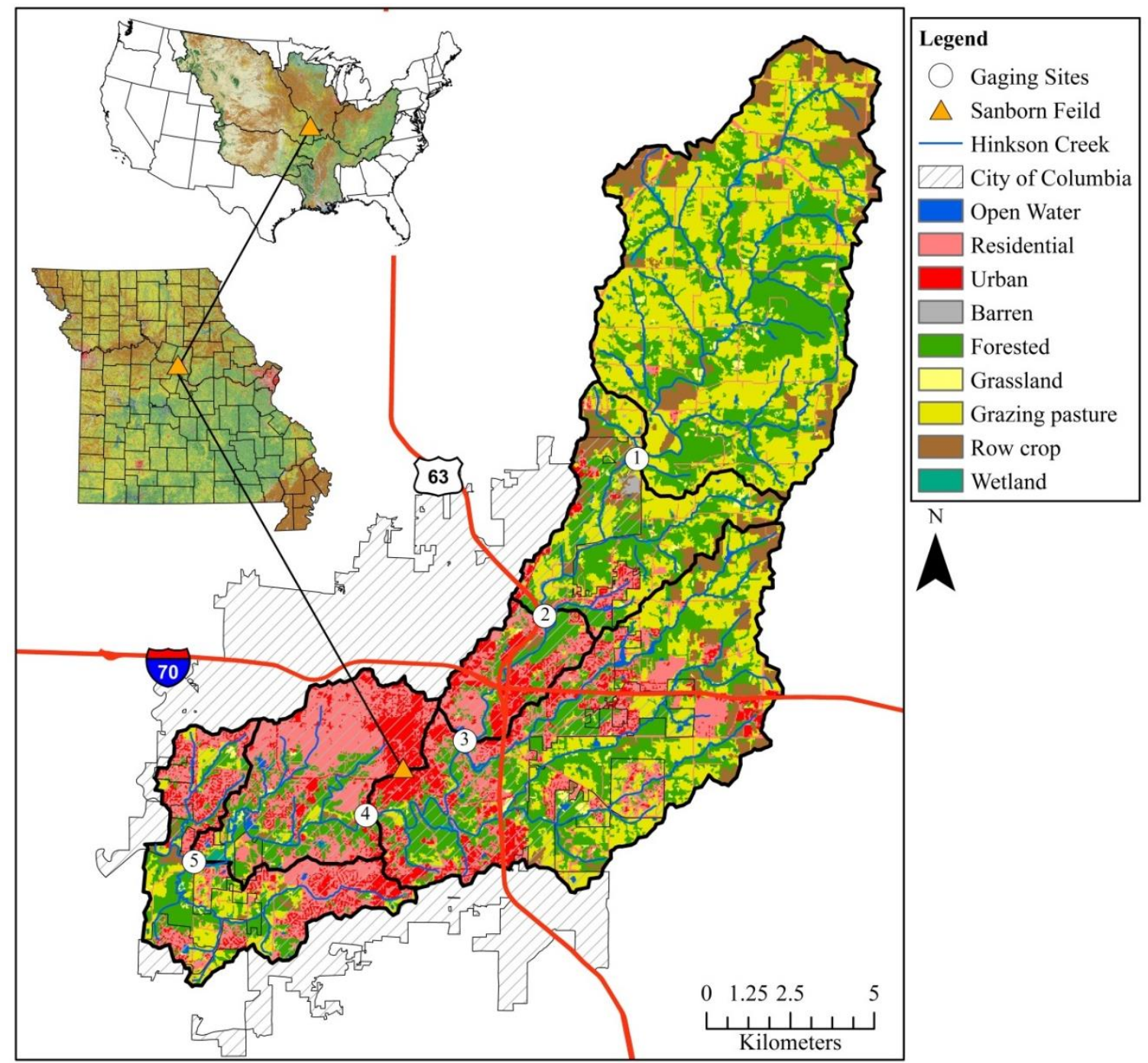

Figure 4.1. Nested-scale experimental watershed study design including five gauging sites located in Hinkson Creek watershed, Missouri, USA.

\section{Observed Data}

Climate stations at each gauging site were used to monitor a complete suite of climate variables (i.e. precipitation, solar radiation, air temperature, relative humidity, and wind speed) used for this research as input data for the SWAT model during the study period (2008-2015) (Figure 4.1). Suspended sediment and nutrient data from over four years (January 2010 through February 2014) of stream grab samples were used to calibrate and validate the SWAT model. Stage-discharge rating curves were developed 
for gauging Sites \#1 through \#5 using stage data and manually measured stream flow. Water samples were collected at each gauging site on a Monday, Wednesday, Friday and Saturday sampling regimen $(n=858$ samples per site). Duplicate grab samples $(n=390)$ were collected on a site rotation every Monday and Wednesday. Samples and corresponding duplicates were not found to be significantly different using one-way ANOVA tests $(C I=95 \%, p>0.709, n=390)$. EPA approved methods of gravimetric analyses (performed using vacuum filtration, ASTM, 2007) and nutrient analyses (conducted using a HACH DR 2800 spectrophotometer, HACH Company, Loveland, $\mathrm{CO}$ ) were used in this work. Nutrient species included $\mathrm{NH}_{4}-\mathrm{N}, \mathrm{NO}_{2}-\mathrm{N}, \mathrm{NO}_{3}-\mathrm{N}$, and TPP concentrations using HACH TNTPlus ${ }^{\mathrm{TM}}$ analytes. Total inorganic nitrogen (TIN-N) was estimated by lumping $\mathrm{NH}_{4}-\mathrm{N}, \mathrm{NO}_{2}-\mathrm{N}$, and $\mathrm{NO}_{3}-\mathrm{N}$ concentrations.

\section{SWAT Modeling and Evaluation}

SWAT 2012 was chosen for the present investigation because it was the most recent version. A 30m digital elevation model, SSURGO soils, and the 2011 National Land Cover Data sets were used for the spatial input data required to create a SWAT project. The SCS curve number method, the Muskingum method, and the PenmanMonteith method were selected to simulate rainfall-runoff, channel routing, and evapotranspiration processes, respectively. Channel degradation, stream water quality, and algae-biochemical oxygen demand-dissolved oxygen simulations were all set to 'active'. The SWAT model was manually calibrated and validated at a monthly time step using a split-time method (Gassman et al., 2007) and the auto-calibration software SWAT-cup (Arnold et al., 2012) for streamflow, sediment, and nutrients. Calibration parameters were set to reflect physically realistic values for the watershed as per SWAT 
model calibration methods proposed by Arnold et al., (2012). Agricultural HRU's were set to a corn-soybean rotation with three fertilization operations (anhydrous ammonia, elemental nitrogen, and elemental phosphorus) and tandem disk tillage in the spring. Grazing pasture HRU's were set to hay growing operations, fertilizer operations (elemental nitrogen, and elemental phosphorus), and grazing operations realistic for HCW. Urban HRU's were set to a tall fescue growing operation with lawn fertilization and street sweeping operations.

It was best practice to calibrate the model in order of 1) stream flow, 2) sediment, and 3) nutrients because model outputs of nutrient yields were dependent on sediment yields and sediment yields are driven by the water balance. Three annual years including 2010 (wet), 2011 (average), and 2012 (dry) were used for calibration at all gauging sites with the exception of Site \#4 (U.S. Geological Survey station in operation since 1967), which was calibrated using five years (2008-2012) of observed stream flow data. The model was validated using two years (2013-2014) of observed stream flow data from the five gauging sites with the exception of Site \#4, which was validated using three years (2013-2015) of observed stream flow data. The model was also validated using one year (2013) of observed sediment and nutrient data (TP-P, $\mathrm{NO}_{3}-\mathrm{N}, \mathrm{NO}_{2}-\mathrm{N}$, and $\mathrm{NH}_{4}-\mathrm{N}$ ) from all five sites.

If the end user has observed data from multiple gauging sites along a stream network, as in this research, then the model can be calibrated for each sub-basin concurrently from the headwaters to the watershed outlet to improve calibration results (Arnold et al., 2012). However, the process is labor intensive and impractical for most end-users. While guidance to SWAT model calibration and validation is available in the 
literature (e.g. Arnold et al., 2012), little guidance to optimize methods for calibrating to multiple gauging sites is available. Therefore, a brief discussion on the methods used in the current work is warranted. It was found that the basin database files should only be calibrated once at upstream-most gauging sites (e.g. Site \#1 in HCW) because each basin parameter only has one value that applies to every sub-basin in SWAT. In other words, adjusting the basin settings at downstream gauging sites changed model evaluation statistics associated with all upstream and downstream sites. Therefore, the basin parameterization files were not changed after calibrated to Site \#1.

Moriasi et al., (2007) suggested the use of Nash-Sutcliffe efficiency (NSE), ratio of root mean square error to the standard deviation of observed data (RSR), and percent bias (PBIAS) to assess model performance. Model performance ratings for each of the three aforementioned model evaluation criteria at a monthly time step are provided in Table 4.2. Nash-Sutcliffe efficiency tests were used to quantify the variance of observed versus simulated data relative to a 1:1 best fit line; NSE values range between $\infty$ and one, where an NSE value of one is a perfect simulation. Any NSE value greater or equal to zero indicates that the simulated value estimated the constituent of concern better than the mean observed value. NSE values were calculated using the following equation:

$$
N S E=1-\left[\frac{\sum_{i=1}^{n}\left(Y_{i}^{o b s}-Y_{i}^{s i m}\right)^{2}}{\sum_{i=1}^{n}\left(Y_{i}^{\text {obs }}-Y_{i}^{\text {mean }}\right)^{2}}\right]
$$

where $Y_{i}^{o b s}$ is the $i^{\text {th }}$ observed datum for the variable being estimated. $Y_{i}^{s i m}$ is the $i^{\text {th }}$ simulated datum for the variable being estimated, $Y_{i}^{\text {mean }}$ is the mean of observed data for the variable being estimated, and $n$ is the total number of observations.

Ratio of root mean square error to the standard deviation is an error index statistic. RSR values of zero equal a perfect simulation. Any RSR value less than 0.50 
indicates an acceptable simulation. RSR values were calculated using the following equation:

$$
R S R=\left[\frac{\sqrt{\sum_{i=1}^{n}\left(Y_{i}^{o b s}-Y_{i}^{\text {sim }}\right)^{2}}}{\sqrt{\sum_{i=1}^{n}\left(Y_{i}^{\text {obs }}-Y_{i}^{\text {mean }}\right)^{2}}}\right]
$$

Percent bias tests were used to indicate the average tendency of simulated data to be greater than or less than the observed data. Any negative PBIAS value indicated the simulated data were greater than the observed data on average. Conversely, any positive PBIAS value indicated the simulate data were less than the observed data on average. A PBIAS value of zero is a perfect simulation. PBIAS values can be calculated using the following equation:

$$
P B I A S=\left[\frac{\sum_{i=1}^{n}\left(Y_{i}^{o b s}-Y_{i}^{s i m}\right) * 100}{\sum_{i=1}^{n}\left(Y_{i}^{o b s}\right)}\right]
$$

Table 4.2. Model efficiency ratings used to assess SWAT model performance of stream flow, sediment and nutrients at a monthly time step. Table recreated from Moriasi et al.

\begin{tabular}{|c|c|c|c|c|c|}
\hline \multirow{2}{*}{$\begin{array}{c}\text { Performance } \\
\text { Rating }\end{array}$} & \multirow[b]{2}{*}{ NSE } & \multicolumn{3}{|c|}{ PBIAS $(\%)$} & \multirow[b]{2}{*}{ RSR } \\
\hline & & Discharge & Sediment & Nutrients & \\
\hline Very good & $x \geq 0.75$ & $|x|<10$ & $|x|<15$ & $|x|<25$ & $x \leq 0.50$ \\
\hline Good & $0.65 \leq x<0.75$ & $10 \leq|x|<15$ & $15 \leq|x|<30$ & $25 \leq|x|<40$ & $0.50<x \leq 0.60$ \\
\hline Satisfactory & $0.50 \leq x<0.65$ & $15 \leq|x|<25$ & $30 \leq|x|<55$ & $40 \leq|x|<70$ & $0.60<x \leq 0.70$ \\
\hline Unsatisfactory & $x<0.50$ & $|x| \geq 25$ & $|x| \geq 55$ & $|x| \geq 70$ & $x>0.70$ \\
\hline
\end{tabular}
(2007).

\section{Results}

Observed Data

Eight-year average (2008-2015) annual total precipitation was $1113.0 \mathrm{~mm}$ with years of extreme climate (Table 4.3). Site \#4 had the longest periods of calibration (20082012) and validation (2013-2015) for stream flow. The calibration period for stream flow 
observed at Site \#4 included three very wet years [1448.0 mm (2008), 1245.0 mm (2009), and $1356.0 \mathrm{~mm}(2010)]$, one average year [922.0 mm (2011)], and one dry year [(669.0 mm (2012)]. Data from Sites \#1, \#2, \#3, and \#5, also included very wet (2010), average (2011), and dry years (2012) during the calibration period. The inclusion of wet, average, and dry years made the data set particularly well-suited for SWAT model calibration. The validation period for stream flow at Site \#4 included three average years of $1105.0 \mathrm{~mm}$ (2013), $1017.0 \mathrm{~mm}$ (2014), and $1144.0 \mathrm{~mm}$ (2015).

Average daily air temperature and relative humidity ranged from $-28.7{ }^{\circ} \mathrm{C} /$ $32.9 \%$, to $42.8{ }^{\circ} \mathrm{C} / 99.4 \%$, respectively with eight-year averages of $12.9{ }^{\circ} \mathrm{C}$ and $70.5 \%$, respectively (2008-2015). Minimum total daily solar irradiance $\left(0.5 \mathrm{MJ} \mathrm{m}^{-2}\right)$ occurred on December $24^{\text {th }} 2010$ (solar declination angle $-23.1^{\circ}$, overcast conditions and snowfall). Maximum solar irradiance exceeded $29.5 \mathrm{MJ} \mathrm{m}^{-2}$ on June $12^{\text {th }} 2012$ (solar declination $23.1^{\circ}$ ). Daily average wind speed ranged from 0.0 to $5.8 \mathrm{~m} \mathrm{~s}^{-1}$, with a mean of $1.4 \mathrm{~m} \mathrm{~s}^{-1}$.

Table 4.3. Summary of daily climate statistics generated from SWAT model input data collected during the study period (2008-2015) in Hinkson Creek Watershed, USA. St. Dev. is standard deviation, Air Temp is air temperature, and $\mathrm{Rh}$ is relative humidity.

\begin{tabular}{llllll}
\hline $\begin{array}{l}\text { Daily } \\
\text { Statistic }\end{array}$ & $\begin{array}{l}\text { Precipitation } \\
(\mathrm{mm}) \dagger\end{array}$ & $\begin{array}{l}\text { Air Temp } \\
\left({ }^{\circ} \mathrm{C}\right)\end{array}$ & $\begin{array}{l}\text { Rh } \\
(\%)\end{array}$ & $\begin{array}{l}\text { Total Solar } \\
\left(\mathrm{MJ} \mathrm{m}^{-2}\right)\end{array}$ & $\begin{array}{l}\text { Wind Speed } \\
\left(\mathrm{m} \mathrm{s}^{-1}\right)\end{array}$ \\
\hline Mean & 1113.0 & 12.9 & 70.5 & 13.5 & 1.4 \\
St. Dev. & 249.0 & 10.8 & 12.3 & 7.5 & 0.8 \\
Minimum & 669.0 & -28.7 & 32.9 & 0.5 & 0.0 \\
Median & 1125.0 & 14.1 & 70.9 & 12.9 & 1.3 \\
Maximum & 1448.0 & 42.8 & 99.4 & 29.5 & 5.8 \\
\hline
\end{tabular}

$\dagger$ Precipitation values were calculated from annual totals.

Median and maximum monthly stream flow was greater at Site \#4 relative to Site \#5 by 0.4 , and $2.4 \mathrm{~m}^{3} \mathrm{~s}^{-1}$, respectively. Monthly average stream flow ranged from 0.9 to 
$2.7 \mathrm{~m}^{3} \mathrm{~s}^{-1}$ from Site \#1 located in the headwaters to \#5 located near the watershed outlet during 2010 to 2014 (Table 4.4). The maximum monthly average stream flow at Sites \#1 $\left(7.3 \mathrm{~m}^{3} \mathrm{~s}^{-1}\right)$ to Site \#5 $\left(13.7 \mathrm{~m}^{3} \mathrm{~s}^{-1}\right)$ occurred during May of 2013 when peak flow exceeded $314 \mathrm{~m}^{3} \mathrm{~s}^{-1}$ at Site \#4.

When sediment loads were calculated using linear interpolation methods, results showed minimum monthly sediment loads ranged from 0.1 mega grams $(\mathrm{Mg})$ at Site \#1 to $2.1 \mathrm{Mg}$ at Site \#5, median sediment load ranged from $11.3 \mathrm{Mg}$ at Site \#2 to $154.8 \mathrm{Mg}$ at Site \#5, and maximum monthly sediment loads ranged from $9840.9 \mathrm{Mg}$ at Site \#1 to 18123.2 Mg at Site \#4 (Table 4.4). Minimum monthly sediment load was $0.3 \mathrm{Mg}$ lesser at Site \#4 relative to Site \#3 during the dry season, and maximum sediment load was approximately 3,500 Mg greater at Site \#4 relative to Site \#5 during the wet season.

Similar trends were observed in the nutrient data from the agricultural and urban regions of the watershed. For example, TP-P and $\mathrm{NO}_{3}-\mathrm{N}$ loads calculated using linear interpolation methods were greater where agricultural land use was greatest at approximately $56 \%$ of the drainage area at Site \#1. Monthly maximum $\mathrm{TP}$ and $\mathrm{NO}_{3}-\mathrm{N}$ loads were 1,938.1 Mg and 1,274.6 kg greater at Site \#1 compared to Site \#2, respectively (Table 4.4). Monthly maximum $\mathrm{NO}_{2}-\mathrm{N}$ and $\mathrm{NH}_{4}-\mathrm{N}$ loads were 3,258.3 kg, and $5813.7 \mathrm{~kg}$, respectively, at Site \#1. There was a trend for median nutrient loads to increase with cumulative stream distance from Sites \#1 to \#5 respectively, with median monthly nutrient loads that ranged from 57.4 to $355.1 \mathrm{~kg}$ TP-P, 386.8 to $2,327.3 \mathrm{~kg} \mathrm{NO}$ N- $^{-}$ $\mathrm{N}, 21.0$ to $151.0 \mathrm{~kg} \mathrm{NO}_{2}-\mathrm{N}$, and 54.5 to $228.2 \mathrm{~kg} \mathrm{NH}_{4}-\mathrm{N}$. 
Table 4.4. Summary of statistics for observed monthly discharge, sediment, total phosphorus, nitrate, nitrite, and ammonium during the study period collected from five gauging sites in Hinkson Creek Watershed, USA. Total phosphorus is TP.

\begin{tabular}{|c|c|c|c|c|c|c|}
\hline Variable & $\begin{array}{l}\text { Monthly } \\
\text { Statistic }\end{array}$ & Site \#1 & Site \#2 & Site \#3 & Site \#4 & Site \#5 \\
\hline \multirow{3}{*}{$\begin{array}{l}\text { Discharge } \dagger \\
\left(\mathrm{m}^{3} \mathrm{~s}^{-1}\right)\end{array}$} & Min & $<0.1$ & $<0.1$ & 0.1 & 0.1 & 0.1 \\
\hline & Median & 0.1 & 0.3 & 0.4 & 1.4 & 1 \\
\hline & $\operatorname{Max}$ & 7.3 & 8.3 & 9.1 & 16.1 & 13.7 \\
\hline \multirow{3}{*}{$\begin{array}{l}\text { Sediment } \\
(\mathrm{Mg})\end{array}$} & Min & 0.1 & 0.3 & 0.4 & 0.1 & 2.1 \\
\hline & Median & 12.8 & 11.3 & 34.0 & 56.5 & 154.8 \\
\hline & Max & 9840.9 & 11424.1 & 17353.4 & 18123.2 & 14600.7 \\
\hline \multirow{3}{*}{$\begin{array}{l}\mathrm{TP} \\
(\mathrm{kg})\end{array}$} & Min & 1.5 & 6.1 & 3.6 & 1.9 & 13.1 \\
\hline & Median & 57.4 & 61.6 & 138.4 & 212.8 & 355.1 \\
\hline & Max & 10108.1 & 8170.0 & 11278.9 & 11766.7 & 15605.6 \\
\hline \multirow[t]{3}{*}{ Nitrate $(\mathrm{kg})$} & Min & 6.8 & 49.3 & 38 & 10.7 & 68.4 \\
\hline & Median & 386.8 & 493.6 & 914.7 & 1701.3 & 2327.3 \\
\hline & Max & 30313.5 & 29038.9 & 34658.6 & 39973.2 & 60271.2 \\
\hline \multirow[t]{3}{*}{ Nitrite (kg) } & Min & 0.4 & 4.8 & 2.3 & 1.1 & 5.1 \\
\hline & Median & 21.0 & 23.8 & 55.4 & 97.7 & 151 \\
\hline & Max & 3258.3 & 3258.9 & 4195.1 & 5225.8 & 6372.6 \\
\hline \multirow{3}{*}{$\begin{array}{l}\text { Ammonium } \\
(\mathrm{kg})\end{array}$} & Min & 1.3 & 9.4 & 6.6 & 3.6 & 18.4 \\
\hline & Median & 54.5 & 65.4 & 143.4 & 189.2 & 228.2 \\
\hline & $\operatorname{Max}$ & 5813.7 & 5277.2 & 7835.1 & 9645.8 & 11944 \\
\hline
\end{tabular}

$\dagger$ Discharge at Site \#4 represents the duration 2008-2015. The other four gauging sites correspond to the duration 2010-2014.

\section{SWAT Modeling and Evaluation}

When the uncalibrated SWAT model was used to simulate monthly stream flow, results showed a model performance rating of very good with NSE $\geq 0.79$, PBIAS $\leq$ $20.0 \%$, and RSR values $\leq 0.46$ at Site \#5 (nearest the watershed outlet). Model evaluation results were also very good upstream at Sites\# 3 and \#4 with NSE $\geq 0.75$, PBIAS $\leq$ $20.0 \%$, and RSR values $\leq 0.50$ (Table 4.5). However, PBAIS values exceeded $\pm 25.0 \%$ at Sites\#1 and \#2 during the calibration period indicating that the uncalibrated model 
generally overestimated stream flow in the agricultural headwaters of the watershed, and thus, did not achieve satisfactory calibration. Additionally, the uncalibrated model did not achieve a satisfactory rating for sediments (NSE $\leq-3.7)$, TP-P (NSE $\leq-13.0), \mathrm{NO}_{3}-\mathrm{N}$ $(\mathrm{NSE} \leq-1.2)$ or TIN-N $(\mathrm{NSE} \leq 0.09)$ during the calibration period. Negative PBIAS values indicated overestimations of sediment, TP-P and $\mathrm{NO}_{3}-\mathrm{N}$ nutrients.

SWAT sediment simulations only exceeded the satisfactory threshold after the model was calibrated concurrently at each gauging site using the observed stream flow and sediment data. Stream flow and sediment had to be calibrated to achieve the satisfactory threshold for TP-P, and $\mathrm{NO}_{3}-\mathrm{N}$. Thus, results showed that the parameter of interest and its independent variable(s) must be calibrated to achieve satisfactory results at a monthly time step, with the exception of stream flow near the watershed outlet (NSE $\geq 0.79$ ). Further, model error increased with distance from the watershed outlet to upstream gauging sites. Stream flow simulations improved post-calibration (particularly at Sites\#1 and \#2), which indicated the benefits of model calibration to multiple gauging sites within a watershed. Sediment simulations improved after model calibration to observed stream flow and sediment data with NSE values ranging from 0.52 at Site \#4 to 0.68 at Site \#2 during the calibration period (Table 4.5). However, the sediment load transported by the extreme rainfall-runoff event that occurred during May 2013 of the validation period was under-estimated, particularly at Sites\#1 and \#3 resulting in PBIAS values of 46.6 and $42.1 \%$, respectively (PBIAS $>0.0=$ model underestimation). The uncalibrated model greatly over-estimated sediment loads, particularly during the wet season of 2010, with PBAIS values ranging from $-240 \%$ to $-570 \%$ during the calibration period. Adjusting model parameters to reduce sediment loads led to an acceptable amount 
of under-estimation of sediment load during the validation period with PBIAS ranging from $23 \%$ to $47 \%$, particularly during May 2013 when maximum stream flow volume and sediment loading were observed.

The SWAT model did not simulate TP-P satisfactorily prior to calibration (Table 4.5). However, following the flow, sediment and TP-P calibration phases, the SWAT model simulated total phosphorus very well (the best rating). In fact, TP-P outputs were the best overall model evaluation results after the model was completely calibrated at a monthly time step with NSE values greater than 0.62 , PBIAS less than $27.0 \%$, and RSR less than 0.62 during the calibration and validation periods (Table 4.5). Thus, results indicated that the SWAT model did not simulate monthly TP-P satisfactorily, but calibration greatly improved model performance.

While monthly $\mathrm{NO}_{3}-\mathrm{N}$ simulations were good during the calibration period, the model output received a rating of unsatisfactory during the validation period. For example, NSE values were greater than 0.73 during the calibration period, but NSE values ranged from 0.26 at Site \#1 to 0.52 at Site \#4 during the validation period (Table 4.5). The greatest model error occurred during March, April and May (the wet season) of the validation period. Simulated peak monthly $\mathrm{NO}_{3}-\mathrm{N}$ loads ranged from 4,500 $\mathrm{kg}$ at Site \#1 to $21,300 \mathrm{~kg}$ at Site \#5 during March primarily due to modeled fertilizer applications followed by a rainfall-runoff event. Conversely, the observed peak monthly $\mathrm{NO}_{3}-\mathrm{N}$ loads (greater than 60,000 kg at Site \#5) occurred during April and May (the wettest months of the year) in response to the largest peak flow event of the study period. These results highlighted the importance of the timing and magnitude of simulated fertilizer applications relative to rainfall-runoff events. 
SWAT model simulations of cumulative $\mathrm{NO}_{2}-\mathrm{N}$ and $\mathrm{NH}_{4}-\mathrm{N}$ loads were greatly underestimated. For example, observed data indicated cumulative maximum monthly $\mathrm{NO}_{2}-\mathrm{N}$ loads ranged from 3,258 $\mathrm{kg}$ at Site \#1 to $6372.6 \mathrm{~kg}$ at Site \#5. Conversely, the SWAT model simulated maximum monthly $\mathrm{NO}_{2}-\mathrm{N}$ loads of $0.00 \mathrm{~kg}$ at Site \#1 to $0.22 \mathrm{~kg}$ at Site \#5. In other words, simulated $\mathrm{NO}_{2}-\mathrm{N}$ was approximately four orders of magnitude less than the observed data even after every calibration parameter that directly influenced $\mathrm{NO}_{2}-\mathrm{N}$ and $\mathrm{NH}_{4}-\mathrm{N}$ was adjusted in SWAT-cup to maximize $\mathrm{NO}_{2}-\mathrm{N}$ and $\mathrm{NH}_{4}-\mathrm{N}$. However, total inorganic nitrogen (TIN-N) estimations were very good during the calibration period (NSE $\geq 0.66$, PBIAS less than $\pm 37.0 \%$, RSR $<0.58$ ), similar to the model evaluation results for $\mathrm{NO}_{3}-\mathrm{N}$, because TIN was composed of $79 \% \mathrm{NO}_{3}-\mathrm{N}$. 
Table 4.5. Monthly SWAT model evaluation statistics from five gauging sites in Hinkson Creek watershed, USA. Uncalibrated model evaluation statistics are shown in parenthesis. NSE is Nash-Sutcliffe model efficiency coefficient, PBIAS is percent bias, RSR is the ratio of the root mean square error to the standard deviation of the observed data, $\mathrm{Q}$ is discharge, SS is suspended sediment, TP is total phosphorus, and TIN is total inorganic nitrogen.

\begin{tabular}{|c|c|c|c|c|c|c|c|}
\hline & & Calibration & & & Validation & & \\
\hline Factor & Site \# & NSE & PBIAS & RSR & NSE & PBIAS & RSR \\
\hline \multirow[t]{5}{*}{ Q } & Site $\# 1 \dagger$ & $0.68(0.63)$ & $-19(-45)$ & $0.56(0.61)$ & $0.61(0.70)$ & $5.4(3.7)$ & $0.63(0.55)$ \\
\hline & Site $\# 2 \dagger$ & $0.66(0.50)$ & $-20(-47)$ & $0.58(0.70)$ & $0.78(0.81)$ & $2.7(-0.89)$ & $0.47(0.44)$ \\
\hline & Site \#3† & $0.77(0.75)$ & $-2.1(-20)$ & $0.48(0.50)$ & $0.76(0.80)$ & $14(14)$ & $0.49(0.45)$ \\
\hline & Site \#4† & $0.78(0.75)$ & $1.1(-5.2)$ & $0.47(0.50)$ & $0.76(0.75)$ & $16(20)$ & $0.49(0.50)$ \\
\hline & Site \#5† & $0.83(0.79)$ & $-5.8(-14)$ & $0.42(0.46)$ & $0.82(0.81)$ & $14(20)$ & $0.42(0.43)$ \\
\hline \multirow[t]{5}{*}{ SS } & Site \#1§ & $0.78(-21)$ & $12(-570)$ & $0.47(4.7)$ & $0.47(0.80)$ & $47(-28)$ & $0.73(0.45)$ \\
\hline & Site $\# 2 \dagger$ & $0.64(-18)$ & $12(-520)$ & $0.6(4.3)$ & $0.62(0.81)$ & $33(-63)$ & $0.62(0.44)$ \\
\hline & Site \#3§ & $0.67(-7.4)$ & $18(-360)$ & $0.57(2.9)$ & $0.49(0.76)$ & $42(-7.0)$ & $0.71(0.49)$ \\
\hline & Site $\# 4 \dagger$ & $0.57(-7.9)$ & $-9.3(-460)$ & $0.66(3.0)$ & $0.62(0.86)$ & $23(-39)$ & $0.61(0.38)$ \\
\hline & Site $\# 5 \dagger$ & $0.52(-3.7)$ & $28(-240)$ & $0.69(2.2)$ & $0.61(0.75)$ & $34(-13)$ & $0.62(0.50)$ \\
\hline \multirow[t]{5}{*}{ TP } & Site \#1† & $0.81(-15)$ & $-14(-510)$ & $0.43(4.0)$ & $0.64(0.71)$ & $26(0.26)$ & $0.60(0.54)$ \\
\hline & Site $\# 2 \uparrow$ & $0.71(-18)$ & $-13(-590)$ & $0.53(4.3)$ & $0.82(0.64)$ & $0.95(-54)$ & $0.42(0.60)$ \\
\hline & Site $\# 3 \dagger$ & $0.79(-13)$ & $-6.1(-440)$ & $0.46(3.8)$ & $0.74(0.76)$ & $8.7(-22)$ & $0.51(0.49)$ \\
\hline & Site $\# 4 \dagger$ & $0.79(-24)$ & $-27(-550)$ & $0.45(5.0)$ & $0.81(0.50)$ & $-12(-68)$ & $0.44(0.70)$ \\
\hline & Site $\# 5 \dagger$ & $0.62(-25)$ & $-27(-460)$ & $0.62(5.1)$ & $0.74(0.62)$ & $3.1(-38)$ & $0.51(0.62)$ \\
\hline \multirow[t]{5}{*}{ Nitrate } & Site \#1§ & $0.90(-1.2)$ & $9.6(-51)$ & $0.32(1.5)$ & $0.26(-0.13)$ & $55(44)$ & $0.86(1.1)$ \\
\hline & Site \#2§ & $0.85(-1.6)$ & $6.1(-68)$ & $0.38(1.6)$ & $0.47(-0.40)$ & $35(11)$ & $0.73(1.2)$ \\
\hline & Site \#3§ & $0.87(-1.3)$ & $21(-44)$ & $0.36(1.5)$ & $0.37(-0.19)$ & $44(27)$ & $0.79(1.1)$ \\
\hline & Site $\# 4 \dagger$ & $0.88(-3.5)$ & $10(-100)$ & $0.34(2.1)$ & $0.52(-0.11)$ & $36(15)$ & $0.69(1.1)$ \\
\hline & Site \#5§ & $0.73(-4.9)$ & $16(-94)$ & $0.52(2.4)$ & $0.38(0.02)$ & $48(32)$ & $0.79(0.99)$ \\
\hline \multirow[t]{5}{*}{ TIN } & Site \#1§ & $0.86(0.09)$ & $23(-5.5)$ & $0.37(0.95)$ & $0.20(-0.04)$ & $61(54)$ & $0.90(1.0)$ \\
\hline & Site \#2§ & $0.80(-0.11)$ & $25(-8.2)$ & $0.45(1.1)$ & $0.34(-0.20)$ & $50(36)$ & $0.81(1.1)$ \\
\hline & Site \#3§ & $0.76(0.05)$ & $37(8.1)$ & $0.49(0.98)$ & $0.25(-0.14)$ & $57(46)$ & $0.87(1.1)$ \\
\hline & Site \#4§ & $0.78(-0.28)$ & $28(-17)$ & $0.47(1.1)$ & $0.36(-0.21)$ & $50(39)$ & $0.80(1.1)$ \\
\hline & Site \#5§ & $0.66(-0.61)$ & $33(-16)$ & $0.58(1.3)$ & $0.21(-0.04)$ & $62(48)$ & $0.89(1.0)$ \\
\hline
\end{tabular}

$\dagger$ Model evaluation results were at least satisfactory for both the calibration and validation periods. $\S$ Model evaluation results were at least satisfactory for only the calibration period. 


\section{Discussion}

The period June 2012 - August 2012, was characterized by extreme (D3) to exceptional (D4) drought (USDM Drought Severity Classification; Svoboda et al., 2002), and was ranked as one of the hottest and driest on record for the region (Kutta and Hubbart, 2014). Conversely, precipitation during the 2013 and 2014 water years was 960 and $867 \mathrm{~mm}$, respectively. The variable of hydrologic conditions during the study period were suited for a unique opportunity to test model estimations during highly variable climatic conditions. Ultimately, the observed extreme wet and dry climate that occurred during the calibration period (Figure 4.2) coupled with the effects of multiple-land-uses complicated SWAT model validation. The calibration period for stream flow included the wettest years $(2008,2009$, and 2010). However, a large event that occurred during May 2013 transported the greatest amount of observed sediment, TP-P, and TIN-N, in part, due to source-sink pollutant relationships and over bankfull events that the SWAT model did not simulate well. Additionally, inaccurate water and pollutant routing may have been linked to the digital elevation models (DEM) used in this work. DEM's are used to provide an approximation of natural flow paths of water and pollutants as described by McDonnell (2003). However, urban areas are saturated with man-made flow paths that are not always mirrored accurately by surface DEM data at a 30-meter resolution. These urban stormwater drainage systems alter the timing and magnitude of stream flow (Walsh et al., 2005). Simulating the effects of increased impervious surfaces coupled with the largest observed rainfall-runoff events are challenging for long-term continuous watershed-scale models (Borah et al., 2006). 


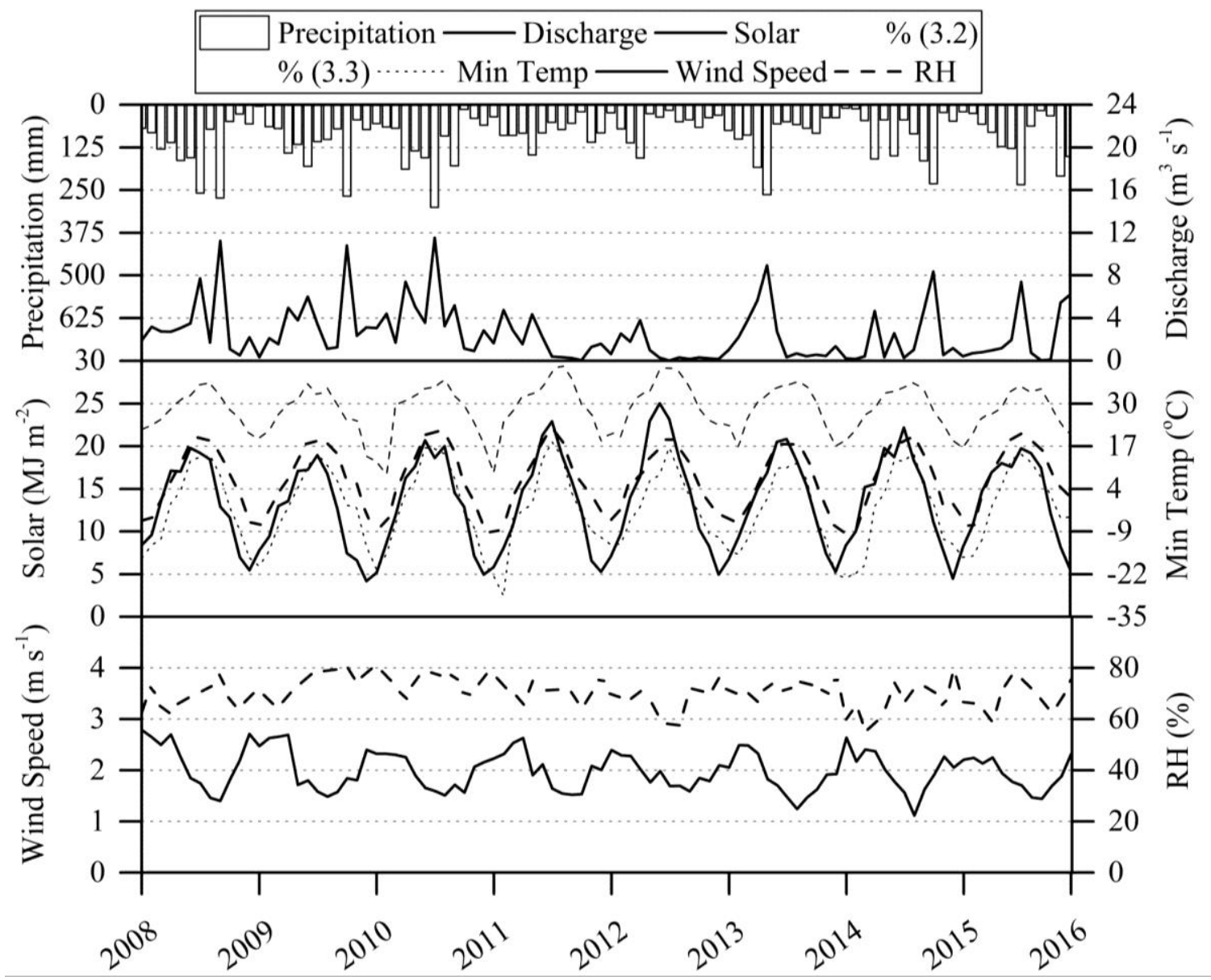

Figure 4.2. Observed monthly climate data during the study period (2008-2015) in Hinkson Creek Watershed, USA. Monthly discharge data from Site \#4.

Calibrating the SWAT model concurrently to multiple sub-basins improved model results at upstream sub-basins. The power (i.e. sensitivity) of calibration parameters was, in part, dependent on the drainage area of an individual sub-basin relative to the cumulative drainage area of all upstream sub-basins. For example, calibration parameters at Site \#3 were less sensitive because Site \#3 only accounted for $13 \%$ of the cumulative drainage area. The problem was not an issue if the model was well-calibrated upstream (e.g. $0.50<\mathrm{RSR} \leq 0.60 ; 0.65<\mathrm{NSE} \leq 0.75 ; \pm 10 \leq \operatorname{PBIAS}< \pm 15$ ) and if there were no important changes in watershed hydrology between the two sites. While there were changes in watershed hydrology between Sites\#3 and \#4 where the 
study catchment is divided by two Class II Ecoregions (Great Plains in at Sites\#1, \#2, and \#3, and Ozark Highlands at Sites\#4 and \#5), Site \#4 accounts for 45\% of the cumulative drainage area. The $45 \%$ increase in drainage area increased the sensitivity of model calibration parameters at Site \#4 making it possible to account for important changes in watershed hydrology between Sites\#3 and \#4. However, there was only a 13\% difference in drainage area between Sites\#4 and \#5 which made it difficult to account for the increase in urban land use associated with Site \#5.

Nutrient simulations (particularly TP-P loads) were associated with the greatest error at Site \#5 during the calibration period with RSR values of $0.62,0.52$, and 0.58 for TP-P, $\mathrm{NO}_{3}-\mathrm{N}$, and TIN, respectively, presumably in part, because sediment loads were underestimated $(\mathrm{PBIAS}=28.0 \%)$. However, the larger issue with $\mathrm{NO}_{3}-\mathrm{N}$ simulations was the lack of information regarding the timing and magnitude of fertilizer inputs associated with each HRU during the validation period. For example, simulated monthly $\mathrm{NO}_{3}-\mathrm{N}$ peaked in March every odd year because the model was parameterized to apply approximately $34 \mathrm{~kg} \mathrm{ha}^{-1}$ elemental nitrogen and $170 \mathrm{~kg} \mathrm{ha}^{-1}$ anhydrous ammonium on March $23^{\text {rd }}$ to fertilize a corn / soybean row crop operation in agricultural HRUs. Then, a rainfall-runoff event that occurred on March $24^{\text {th }} 2010$ lead to increased simulated nutrient loading. To force the model to calibrate to the rating of satisfactory, fertilizer applications were moved from March $23^{\text {rd }}$ to March $15^{\text {th }}$. Conversely, observed $\mathrm{NO}_{3}-\mathrm{N}$ spiked in May during the validation period causing an overestimation of simulated $\mathrm{NO}_{3^{-}}$ N. These results indicate that lack of information regarding the spatio-temporal variability of fertilizer applications can complicate model calibration and validation of nitrogen species at a monthly time step. 
Model simulations of the transport of $\mathrm{NO}_{3}-\mathrm{N}$ from the field to the stream network were not in synchrony with precipitation events following the application of fertilizers during March. For example, observed nitrate transport was initiated during the largest flushing event that occurred on May $31^{\text {st }} 2013$ when stream flow peaked at over $310 \mathrm{~m}^{3} \mathrm{~s}^{-1}$ at Site \#4. Zeiger and Hubbart (2015b) showed nutrient yields were dependent on annual precipitation of the preceding year (2012 was a year of drought in $\mathrm{HCW}$ ) thus enforcing source-sink nutrient yield relationships in the study catchment. Kirchner (2003), and Phillips (2003) noted that 'old water' carrying chemicals can move through the sub-surface and spill over into nearby stream networks after large precipitation events effectively ‘turn on' sub-surface hydraulic systems. Sediment and TP-P do not move as readily through subsurface systems as $\mathrm{NO}_{3}-\mathrm{N}$. In the current study, relationships between observed monthly discharge and simulated monthly sediment and TP-P were best described by a power function $\left(r^{2}>0.97\right)$, but a relationship between observed discharge and simulated $\mathrm{NO}_{3}-\mathrm{N}$ was not apparent $\left(r^{2}=0.0076\right)$ during March through May of the validation period. SWAT simulations of discharge increased while $\mathrm{NO}_{3}-\mathrm{N}$ decreased from 16,000 kg during March, to 13,000 kg during April, and 12,000 kg during May 2013. Conversely, Figure 4.3 illustrates how observed discharge and $\mathrm{NO}_{3}-\mathrm{N}$ spiked with a large event during May 2013. Pre-event water may have dominated storm runoff in the observed $\mathrm{NO}_{3}-\mathrm{N}$ data, but not in the simulated $\mathrm{NO}_{3}-\mathrm{N}$ time series. Adjusting groundwater $\mathrm{NO}_{3}-\mathrm{N}$ calibration parameters did not substantially increase simulated $\mathrm{NO}_{3}-\mathrm{N}$ loads during April and May. These results are in agreement with McDonnell (2003) and Kirchner (2003), at least pertaining to $\mathrm{NO}_{3}-\mathrm{N}$, in that the hydrologic groundwork presented by Horton and Hewlett (1967) may need to be updated to simulate complex 
subsurface routing of water and chemicals. Given this finding, hybridizing the SCS curve number methods used in SWAT with Hortonian mechanics as proposed by Gabellani $e t$ al., (2008), or variable source area mechanics as proposed by Easton et al. (2008) may be a step in the wrong direction toward improving the SWAT model predictions of chemicals. Instead of adding Hortonian or VSA mechanics to the SWAT model, future changes focused on accounting for the non-linear storage and threshold dependent movement of $\mathrm{NO}_{3}-\mathrm{N}$ rich water near the soil-bedrock interface may result in more realistic simulations of sub-surface hydraulics. 


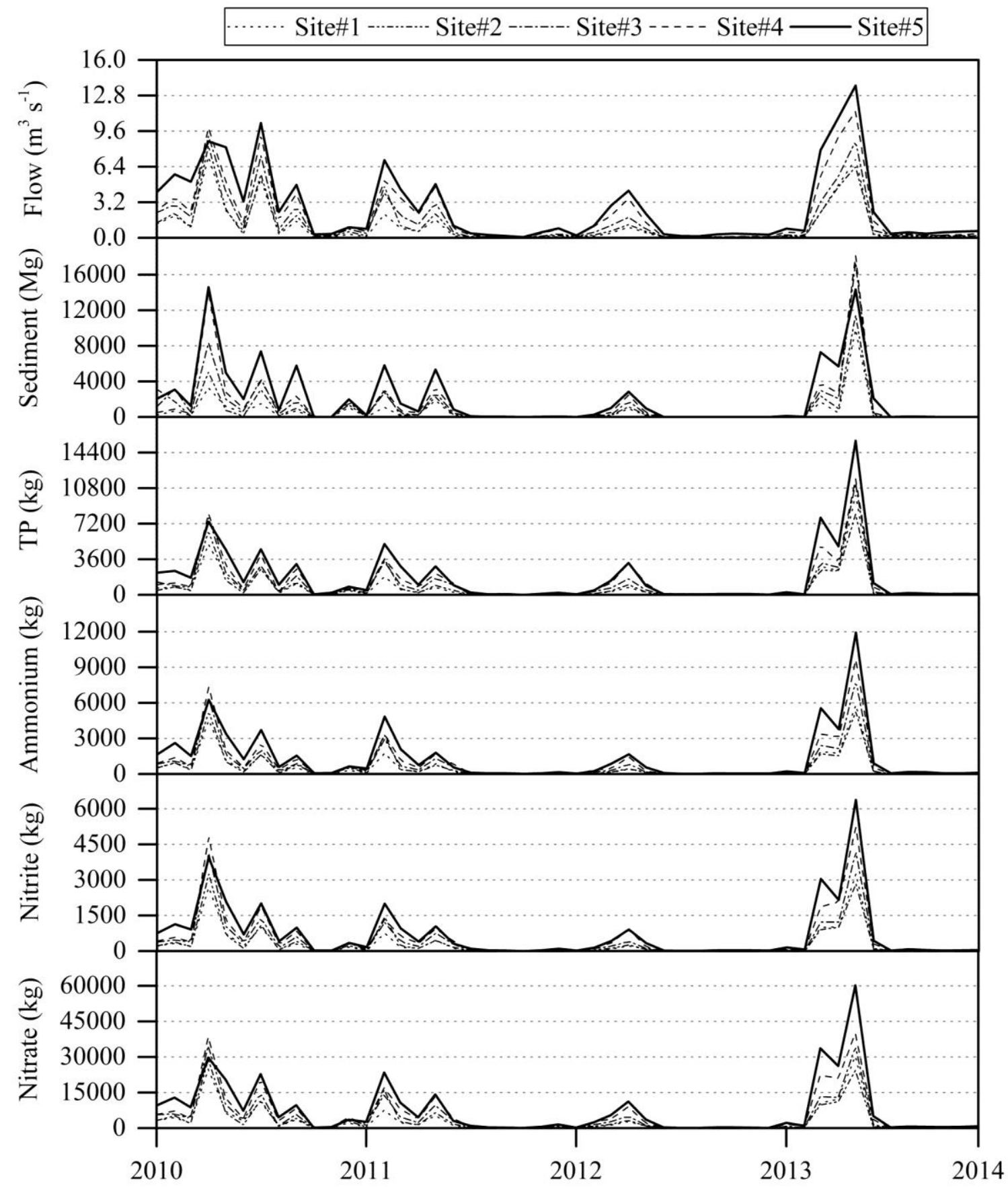

Figure 4.3. Observed monthly discharge (Flow), sediment, total phosphorus (TP), ammonium, nitrite, and nitrate collected during 2010-2013 from five gauging sites in Hinkson Creek Watershed, USA.

It is understood that the majority of water, sediment and chemicals are transported during flooding events (Borah et al., 2006). Thus, accurate model simulations of total water, sediment, and nutrient loads are largely dependent on accurate simulations of peak 
flows during the wettest months. Examination of simulated daily stream flow data showed underestimation of peak flows where the slope of the best fit line (observed vs. simulated daily discharge) decreased by $43 \%$ from Site \#1 to Site \#5 as drainage area and urban land use increased by approximately $130 \mathrm{~km}^{2}$ and $22 \%$, respectively (Figure 4.4). This was, in part, the reason why simulating for climate extremes made model calibration and validation challenging, particularly for sediment (Figure 4.5) considering sediment yields are a function of peak runoff (Neitsch et al., 2009). The majority of model error occurred when peak flows were under-estimated during May 2013, the wettest month of the validation period (Figure 4.6). The SWAT model has been cited to have problems with extremely wet and dry periods (Bryant et al., 2006), especially when extreme events occur during the validation period (USEPA, 2002). Improving the accuracy of peak flow estimates is an ongoing challenge for SWAT developers (Arnold et al., 2012; Gassman et al., 2007; Moriasi et al., 2007). One emergent solution from the literature (Moriasi et al., 2007; Gan et al., 1997) and the current research may be to calibrate the model to observed climate extremes with the inclusion of wet, average and dry years in the calibration period. However, despite this ability in this work, the extreme event that occurred during May 2013 of the validation period was still underestimated in terms of flow, suspended sediment, and nutrients. Thus, there is a need for future work to improve model simulations of peak flow during extreme events when stage increases over bankfull.

The results from this model assessment are in agreement with previous studies in that model performance was generally less accurate during the validation period when calibration parameters are not adjusted to match observed data. For example, Moriasi et 
al., (2007) showed calibration and validation results for monthly stream flow $(n=33)$, sediment $(n=6)$, TP-P $(n=1)$, and $\mathrm{NO}_{3}-\mathrm{N}(n=2)$ with median NSE values of 0.79 and 0.63 (stream flow), 0.76 and 0.64 (sediment), 0.51 and 0.37 (TP-P), and 0.26 and $0.70\left(\mathrm{NO}_{3}{ }^{-}\right.$ N) during the calibration and validation periods, respectively. More recently, Lee et al. (2010) presented NSE values for sediment, TP-P and $\mathrm{NO}_{3}-\mathrm{N}$ of $0.88,0.72$, and 0.68 , respectively, similar to the results observed in the current work. Lam et al., (2010), Akhavan et al., (2010), presented daily $\mathrm{NO}_{3}-\mathrm{N}$ simulations with $\mathrm{NSE}$ values greater than 0.68, while Du et al., (2006) showed monthly $\mathrm{NO}_{3}-\mathrm{N}$ simulations with NSE values greater than 0.85 during the calibration period and 0.67 during the validation period. Future collaborations between research hydrologists and hydrologic model developers may improve model performance by integrating field experiments with improved physically-based mathematical models for routing water, sediment and chemicals from each HRU to the stream network.

Few authors have presented SWAT model evaluation results of $\mathrm{NO}_{2}-\mathrm{N}$ and $\mathrm{NH}_{4}-$ N (Gassman et al., 2007; Moriasi et al., 2007). Grunwald and Qi (2006) showed results of monthly $\mathrm{NO}_{3}-\mathrm{N}, \mathrm{NO}_{2}-\mathrm{N}$ and $\mathrm{NH}_{4}-\mathrm{N}$ from three gauges located in Sandusky watershed, Ohio, USA. NSE values ranged from -4.64 to $0.19\left(\mathrm{NO}_{2}-\mathrm{N}\right),-0.12$ to $0.29\left(\mathrm{NO}_{3}-\mathrm{N}\right)$, and 0.44 to $-0.24\left(\mathrm{NH}_{4}-\mathrm{N}\right)$ during the calibration period, and -0.16 to $0.48\left(\mathrm{NO}_{2}-\mathrm{N}\right),-0.1$ to $0.57\left(\mathrm{NO}_{3}-\mathrm{N}\right)$, and -0.44 to $-0.24\left(\mathrm{NH}_{4}-\mathrm{N}\right)$ during the validation period. Thus, $\mathrm{N}$ species were underestimated with unsatisfactory model calibration results. Similar results were found in the current assessment with regards to $\mathrm{NO}_{2}-\mathrm{N}$ and $\mathrm{NH}_{4}-\mathrm{N}$ simulations that were associated with PBAIS $>99.0 \%$ and $85.0 \%$, respectively. In fact, $\mathrm{NO}_{2}-\mathrm{N}$ simulations reached the maximum possible positive PBIAS value (PBAIS $=100.0 \%$ ). Thus, results of 
the observed versus simulated $\mathrm{NO}_{2}-\mathrm{N}$ and $\mathrm{NH}_{4}-\mathrm{N}$ values appeared as a flat line along the $\mathrm{x}$-axis of the observed versus simulated plots shown in Figures 4.5 and 4.6. No amount of adjusting calibration parameters associated with $\mathrm{NO}_{2}-\mathrm{N}$ and $\mathrm{NH}_{4}-\mathrm{N}$ could bring simulated $\mathrm{NO}_{2}-\mathrm{N}$ and $\mathrm{NH}_{4}-\mathrm{N}$ to the satisfactory threshold. Therefore, aggregating inorganic $\mathrm{N}$ species may be the best practice for $\mathrm{N}$ speciation until SWAT model subroutines of $\mathrm{NO}_{2}-\mathrm{N}$ and $\mathrm{NH}_{4}-\mathrm{N}$ become more effective. For example, it may be appropriate to lump $\mathrm{NO}_{2}-\mathrm{N}$ with $\mathrm{NO}_{3}-\mathrm{N}$ (White and Chaubey 2005; Saleh and Du 2004), $\mathrm{NH}_{4}-\mathrm{N}$ with organic $\mathrm{N}$ (Hanratty and Stefan, 1998), or $\mathrm{NO}_{2}-\mathrm{N}, \mathrm{NH}_{4}-\mathrm{N}$ and $\mathrm{NO}_{3}-\mathrm{N}$ for TIN-N (as in the current work). Lumping inorganic $\mathrm{N}$ species greatly improved model performance results involving $\mathrm{NO}_{2}-\mathrm{N}$ and $\mathrm{NH}_{4}-\mathrm{N}$ with PBIAS values less than $37.0 \%$ (good) during the calibration period. 


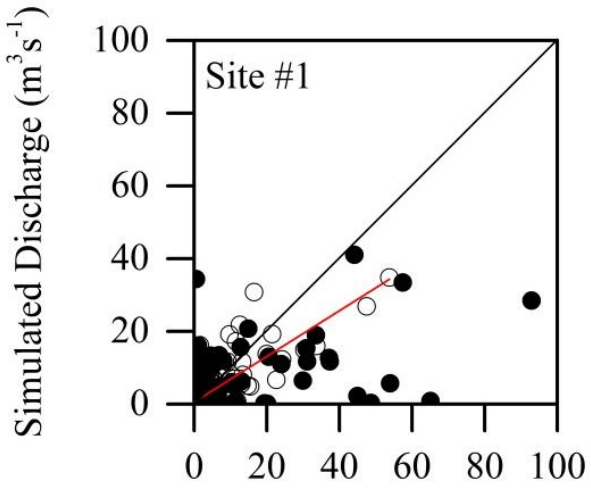

Observed Discharge $\left(\mathrm{m}^{3} \mathrm{~s}^{-1}\right)$

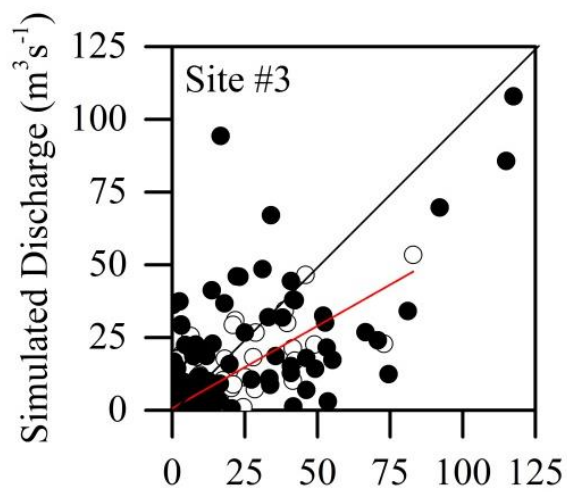

Observed Discharge $\left(\mathrm{m}^{3} \mathrm{~s}^{-1}\right)$

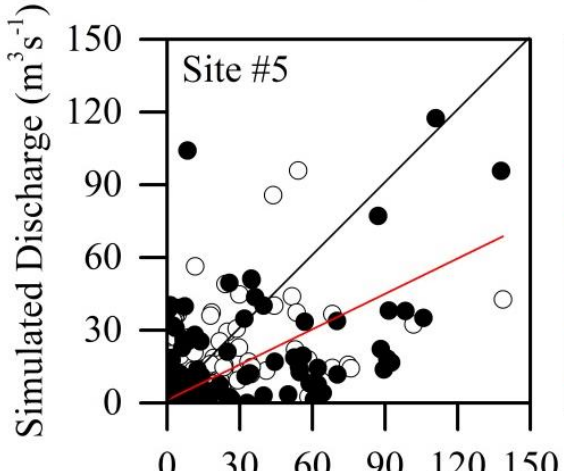

Observed Discharge $\left(\mathrm{m}^{3} \mathrm{~s}^{-1}\right)$

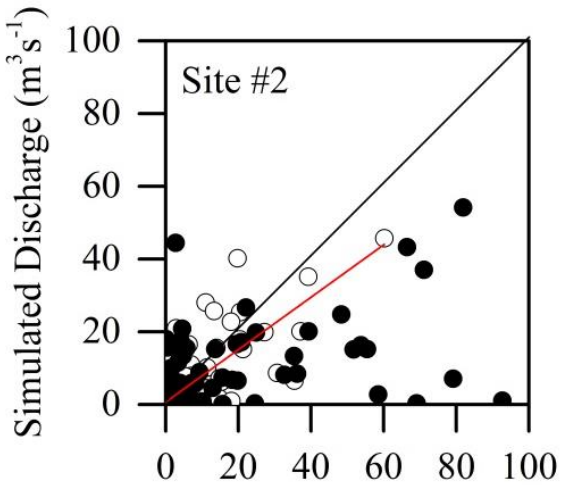

Observed Discharge $\left(\mathrm{m}^{3} \mathrm{~s}^{-1}\right)$

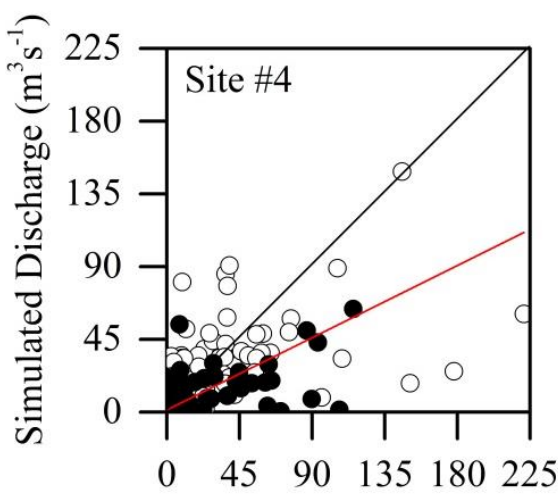

Observed Discharge $\left(\mathrm{m}^{3} \mathrm{~s}^{-1}\right)$

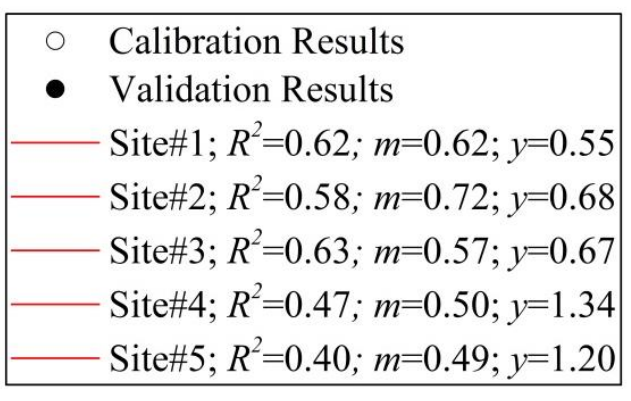

- Validation Results

Site\# $1 ; R^{2}=0.62 ; m=0.62 ; y=0.55$

Site\#2; $R^{2}=0.58 ; m=0.72 ; y=0.68$

Site\#3; $R^{2}=0.63 ; m=0.57 ; y=0.67$

Site\#5; $R^{2}=0.40 ; m=0.49 ; y=1.20$

Figure 4.4. Calibrated (hollow symbols) and validated (solid symbols) SWAT model results observed (x-axis) versus simulated (y-axis) daily discharge during the validation period from five gauging sites in Hinkson Creek watershed, USA. Coefficient of determination is $R^{2}$, slope is $m$, and the y-intercept is $y$ of the best fit line between observed vs. simulated daily discharge. 


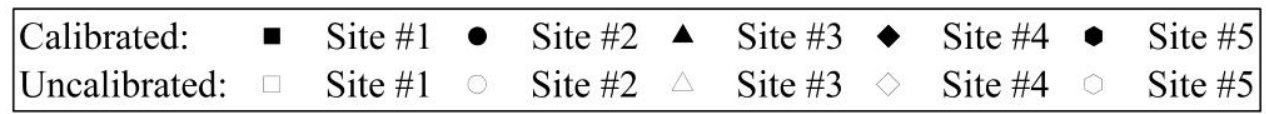

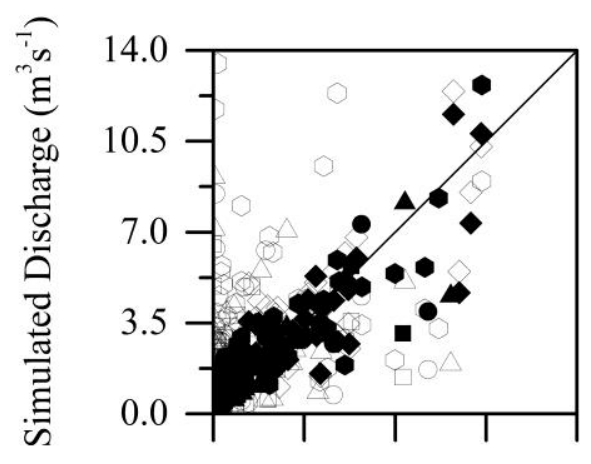

$\begin{array}{lllll}0.0 & 3.5 & 7.0 & 10.5 & 14.0\end{array}$

Observed Discharge $\left(\mathrm{m}^{3} \mathrm{~s}^{-1}\right)$

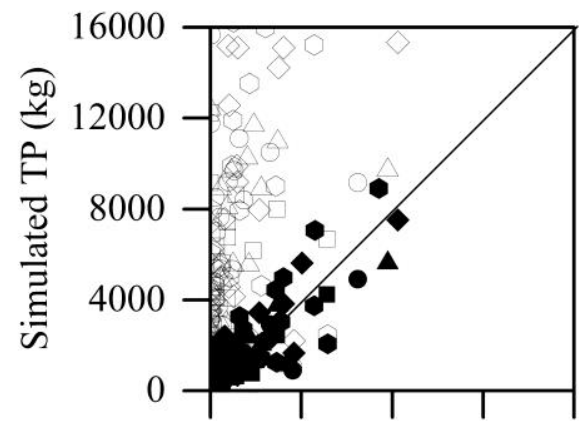

${ }_{4} 0^{0}{ }_{80} 0^{0}{ }_{1200}{ }_{16} 600$

Observed TP $(\mathrm{kg})$

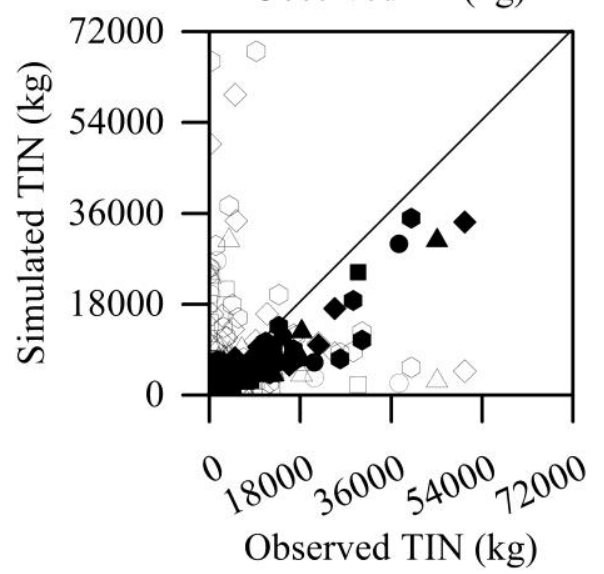

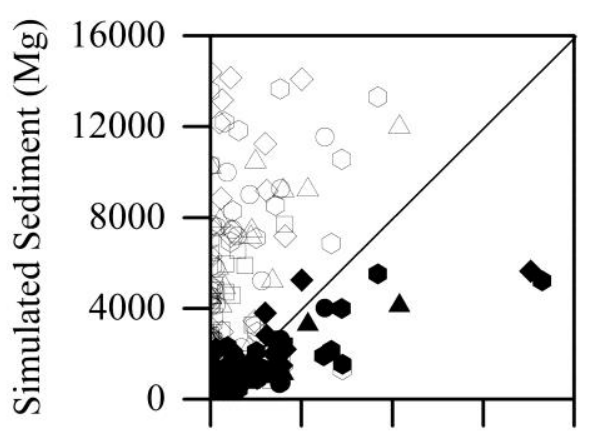

$0_{40} 00{ }_{8} 000,12000,16000$

Observed Sediment (Mg)

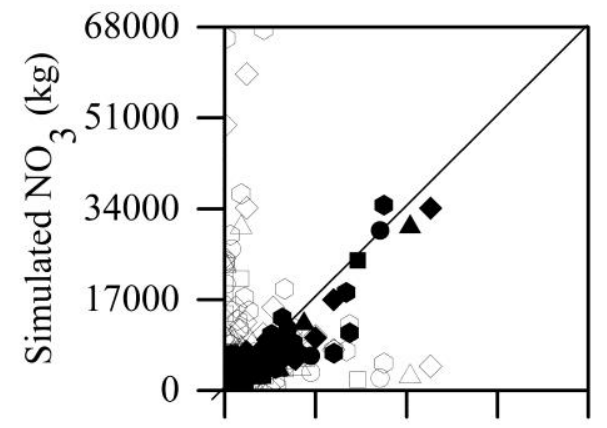

${ }_{17}, 00{ }_{34} 400{ }_{51}, 000_{68} 000$

Observed $\mathrm{NO}_{3}(\mathrm{~kg})$

Figure 4.5. Uncalibrated (hollow symbols) and calibrated (solid symbols) SWAT model results observed (x-axis) versus simulated (y-axis) discharge, sediment, total phosphorus (TP), nitrate $\left(\mathrm{NO}_{3}\right)$, and total inorganic nitrogen (TIN) during the calibration period from five gauging sites in Hinkson Creek watershed, USA. 


\begin{tabular}{|c|c|c|c|c|c|c|c|c|c|c|}
\hline Calibrated: & a & Site \#1 & $\bullet$ & Site \#2 & $\Delta$ & Site \#3 & $\diamond$ & Site \#4 & $\bullet$ & Site \#5 \\
\hline Uncalibrated: & $\square$ & Site \#1 & 0 & Site \#2 & $\triangle$ & Site \#3 & $\diamond$ & Site \#4 & 0 & Site \#5 \\
\hline
\end{tabular}

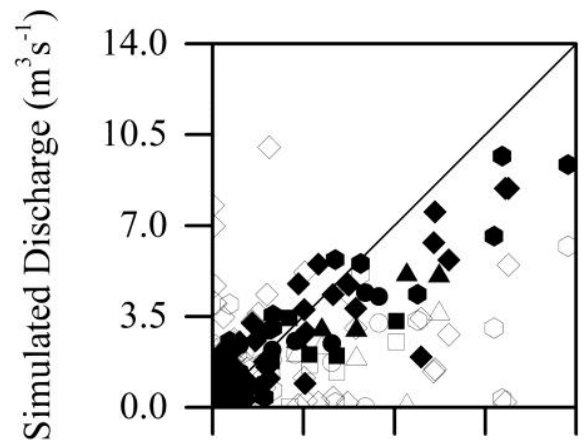

$0.0 \quad 3.5 \quad 7.0 \quad 10.5 \quad 14.0$

Observed Discharge $\left(\mathrm{m}^{3} \mathrm{~s}^{-1}\right)$

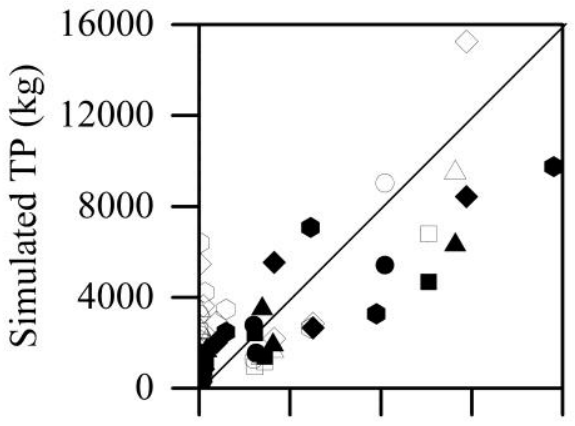

$0_{400}{ }_{8000}{ }_{12000}{ }_{16} 000$

Observed TP $(\mathrm{kg})$

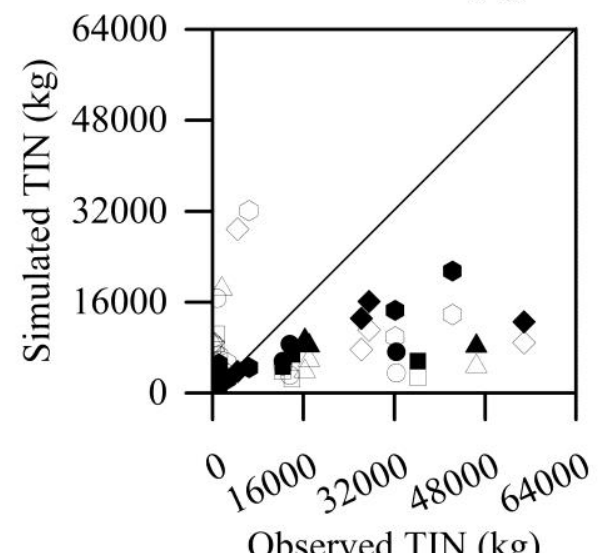

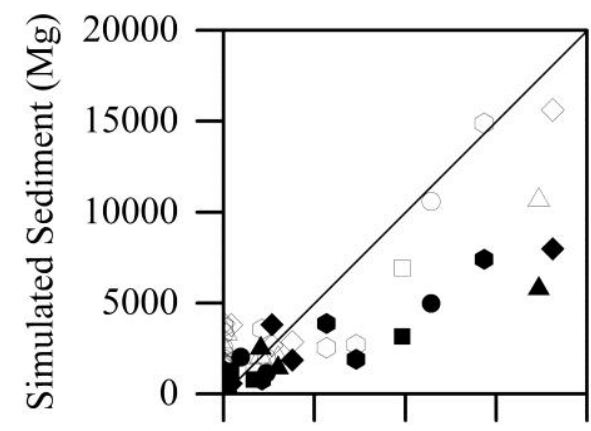

$0_{500}{ }_{100} 0_{15} 0_{20}{ }_{2000}$

Observed Sediment $(\mathrm{Mg})$

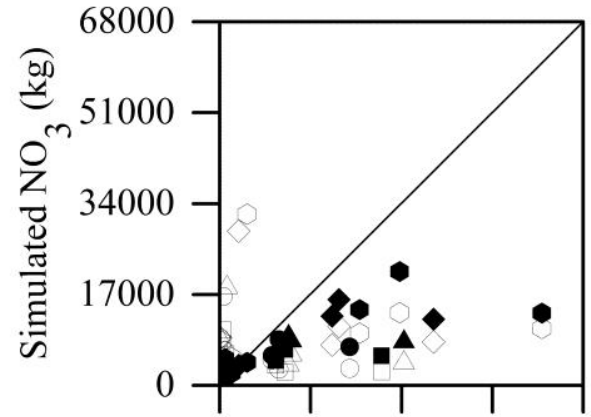

$0_{170}{ }_{34} 400{ }_{5} 1000_{68} 000$

Observed $\mathrm{NO}_{3}(\mathrm{~kg})$

Figure 4.6. Uncalibrated (hollow symbols) and calibrated (solid symbols) SWAT model results observed (x-axis) versus simulated (y-axis) discharge, sediment, total phosphorus (TP), nitrate $\left(\mathrm{NO}_{3}\right)$, and total inorganic nitrogen (TIN) during the validation period from five gauging sites in Hinkson Creek watershed, USA. 


\section{Implications for model development}

Peak flow estimates were underestimated, which led to underestimations of sediment and nutrients in this model performance assessment. Borah et al., (2006) suggested combining a short-term storm event model [i.e. the dynamic watershed simulation model (DWSM)] with SWAT to improve SWAT estimates of peak flow. A SWAT-DWSM hybrid model may also improve the routing of flow and pollutants between HRU's within a sub-basin, especially subsurface lateral flow. While additional spatial complexity in the routing phase could improve model performance, increased spatial complexity increases the computational requirements and may make the model less user-friendly. Therefore, a balance between spatial complexity and ease of use will be needed (Gassman et al., 2007).

While model calibration greatly improved sediment and TP-P simulations, most model users do not have sufficient observed sediment and TP-P data to calibrate the SWAT model as done in this work. In this ungauged evaluation, sediment and TP-P simulations were overestimated by the ungauged model during the calibration period when three record setting wet years (2008-2010) occurred. Additionally, Jha et al., (2004) showed a positive relationship between sediment yields and the number of sub-basins in a SWAT model project where sediment yield increased with the number of sub-basins until the area of each sub-basin was 2 to $6 \%$ of the total drainage area. Results from Jha et al., (2004) and the current study highlight a need for improved SWAT model sediment routing and stream channel degradation and deposition routines.

Results of this research indicate a need for improved terrestrial loading algorithms of $\mathrm{NO}_{2}-\mathrm{N}$ and $\mathrm{NH}_{4}-\mathrm{N}$ to the stream network, because model outputs of $\mathrm{NO}_{2}-\mathrm{N}$ and $\mathrm{NH}_{4}^{-}$ 
$\mathrm{N}$ were greatly underestimated pre- and post-calibration. Currently, simulated organic $\mathrm{N}$ and $\mathrm{NO}_{3}-\mathrm{N}$ are the only forms of nitrogen loaded from the land phase into the stream network, which is not realistic because $\mathrm{NO}_{2}-\mathrm{N}$ and $\mathrm{NH}_{4}-\mathrm{N}$ are also present in surface runoff (Turtola and Kemppainen, 1998). Not accounting for terrestrial inputs of $\mathrm{NO}_{2}$ Nand $\mathrm{NH}_{4}-\mathrm{N}$ in surface runoff during the land phase can lead to underestimation of $\mathrm{NO}_{2}$ $\mathrm{N}$ and $\mathrm{NH}_{4}-\mathrm{N}$ in the routing phase by several orders of magnitude. Lumping $\mathrm{NO}_{2}-\mathrm{N}$ and $\mathrm{NH}_{4}-\mathrm{N}$ data with $\mathrm{NO}_{3}-\mathrm{N}$ for TIN-N may be a temporary resolution to the issue, but there remains a need to include terrestrial inputs of $\mathrm{NO}_{2}-\mathrm{N}$ and $\mathrm{NH}_{4}-\mathrm{N}$ in model simulations. Another relatively simplistic solution may be the inclusion of calibration parameters that increase the initial in-stream levels of $\mathrm{NO}_{2}-\mathrm{N}$ and $\mathrm{NH}_{4}-\mathrm{N}$. Until the issue is resolved, instream biological processes dependent on $\mathrm{NO}_{2}-\mathrm{N}$ (e.g. N-cycling) and $\mathrm{NH}_{4}-\mathrm{N}$ (e.g. algal growth) may be inaccurate.

\section{Conclusions}

Ungauged hydrologic model assessments are extremely important because time, money, and raw materials can be wasted on inaccurate and potentially unrealistic model simulated estimates of pollutant loads. However, multi-constituent (stream flow, sediment, and nutrients) datasets necessary for proper hydrologic model validation are rare. In the current model assessment, SWAT model estimations of monthly stream flow, sediment, and nutrients (i.e. TP-P, $\mathrm{NO}_{3}-\mathrm{N}, \mathrm{NO}_{2}-\mathrm{N}, \mathrm{NH}_{4}-\mathrm{N}$, and total inorganic nitrogen) were tested against four years of observed water quantity and quality data collected at five gauging sites located in a rapidly urbanizing mixed-land use watershed of the central USA. The uncalibrated model simulated monthly stream flow well (NSE=0.79, PBIAS=14, and RSR=0.46) at Site \#5 near the watershed outlet. However, sediment and nutrients 
required calibration before satisfactory ratings (e.g. NSE $>0.5$ and RSR $\leq 0.7$ ) were achieved. Calibrating to multiple gauging sites improved model simulations in the headwaters (NSE > 0.68, PBAIS < 23\%, RSR > 0.56), but the process was laborious and thus perhaps impracticable for most model end-users. However, results indicate that the SWAT model should be calibrated to sediment, TP-P or nitrogen species before simulations are deemed satisfactory at a monthly time step in mixed-land-use watersheds. The delicate balance between model confidence and end-user ease-of-use is an ongoing issue for SWAT model and most other model developers. Results from this study show the gravity of the problem and illustrate the great need for investment to advance model development to better simulate multiple-land-use watershed processes.

SWAT model simulations of in-stream $\mathrm{N}$ cycling are a relatively new aspect of the SWAT model. SWAT was developed to simulate riverine loads of $\mathrm{NO}_{2}-\mathrm{N}$ and $\mathrm{NH}_{4}-\mathrm{N}$ by in-stream nutrient cycling of organic $\mathrm{N}$ and $\mathrm{NO}_{3}-\mathrm{N}$ input from the land phase. While organic $\mathrm{N}$ and $\mathrm{NO}_{3}-\mathrm{N}$ are loaded from the land phase to the routing phase, $\mathrm{NH}_{4}$ and $\mathrm{NO}_{2}$ are not, which is not realistic because $\mathrm{NO}_{2}-\mathrm{N}$ and $\mathrm{NH}_{4}-\mathrm{N}$ are transported by precipitation events from landscapes into receiving water bodies. Results show a need for improve nutrient cycling and routing routines in the model. The current work was completed to provide critically needed ungauged model evaluation, calibration and validation results for multiple constituents in a multiple-land-use watershed of the central USA. The study design used in this investigation serves as model study design for scientists and managers wishing to advance mixed-land-use watershed management globally. 


\section{Acknowledgements}

Funding was provided by the Missouri Department of Conservation and the U.S. Environmental Protection Agency Region 7 through the Missouri Department of Natural Resources (P.N: G08-NPS-17) under Section 319 of the Clean Water Act. Results presented may not reflect the views of the sponsors and no official endorsement should be inferred. Collaborators include (but are not limited to) Boone County Public Works, City of Columbia, University of Missouri, and the U.S. Geological Survey. Special thanks are due to Karim Abbaspour, Jeff Arnold, Claire Baffaut, and Mike Sunde, John Schulz, scientists of the University of Missouri Interdisciplinary Hydrology Laboratory, and constructive comments of multiple reviewers that improved the article. 


\section{Literature cited}

Akhavan SJ, Abedi-Koupai SF, Mousavi M, Afyuni S, EslamianS, and Abbaspour KC. 2010. Application of SWAT model to investigate nitrate leaching in HamadanBahar watershed. Iran. J. Agric. Ecosystem and Environ. , 139(4): 675-688.

American Society for Testing and Materials (ASTM). 2007. D 3977 - 97 Standard Methods for Determining Sediment Concentrations in Water Samples.

Arnold JG, Moriasi DN, Gassman PW, Abbaspour KC, White MJ, Srinivasan R, Santhi C, Harmel RD, van Griensven A, Van Liew MW, Kannan N, Jha MK. 2012. SWAT: Model use, calibration, and validation. American Society of Agricultural and Biological Engineers, 55 (4): 1491-1508.

Baffaut, C., E.J. Sadler, and F. Ghidey. 2015. Long-term agroecosystem research in the Central Mississippi River Basin: Goodwater Creek Experimental Watershed flow data. Journal of Environmental Quality, 44:17-26. doi:10.2134/jeq2014.01.0008

Baffaut, C., E.J. Sadler, R.N. Lerch, and N.R. Kitchen. 2009. Nutrient sources and transport from the Goodwater Creek Experimental Watershed. Pap. 097150. Transactions of the ASABE, St. Joseph, MI.

Blanco-Canqui H, Gantzer CJ, Anderson SH, Alberts EE, Ghidey F. 2002. Saturated hydraulic conductivity and its impact on simulated runoff for claypan soils. Soil Science Society of America Journal, 66(5), 1596-1602.

Borah DK, Bera M. 2003. Watershed-scale hydrologic and nonpoint-source pollution models: Review of mathematical bases. Transactions of the ASABE, 46(6): 1553.

Borah DK, Yagow G, Saleh A, Barnes PL, Rosenthal W, Krug EC, Hauck LM. 2006. Sediment and nutrient modeling for TMDL development and implementation. American Society of Agricultural and Biological Engineers, 49(4): 967-986.

Bryant RB, Gburek WJ, Veith TL, and Hively WD. 2006. Perspectives on the potential for hydropedology to improve watershed modeling of phosphorus loss. Geoderma, 131(3-4): 299-307.

Du, B, Saleh A, Jaynes DB, Arnold JG. 2006. Evaluation of SWAT in simulating nitrate nitrogen and atrazine fates in a watershed with tiles and potholes. Transactions of the ASABE, 49(4), 949-959.

Easton ZM, Fuka DR, Walter TM, Cowan DM, Schneiderman EM, Steenhuis TS. 2008. Re-conceptualizing the soil and water assessment tool (SWAT) model to predict runoff from variable source areas. Journal of Hydrology, 348: 279-291.

Ficklin DL, Lou Y, Stewart IT, Maurer EP. 2012. Development and application of a hydroclimatological stream temperature model within the Soil and Water Assessment Tool. Water Resources Research, 48: 116. 
Gabellani S, Silvestro F, Rudari R, Boni G. 2008. General calibration methodology for a combined Horton-SCS infiltration scheme in flash flood modeling. Natural Hazards and Earth System Sciences, 8: 1317-1327.

Gassman PW, Reyes MR, Green CH, Arnold JG. 2007. The Soil and Water Assessment Tool: Historical development, applications, and future research directions. Transactions of the ASABE, 50:1211-1250.

Gan TY, Dlamini EM, Biftu GF. 1997. Effects of model complexity and structure, data quality, and objective functions on hydrologic modeling. Journal of Hydrology, 192(1): 81-103.

Grunwald S, Qi C. 2006. GIS-based water quality modeling in the Sandusky watershed, Ohio, USA. JAWRA, 42(4): 957-973.

Hanratty MP, Stefan HG. 1998. Simulating climate change effects in a Minnesota agricultural watershed. Journal of Environmental Quality, 27(6): 1524-1532.

Hubbart JA, Kellner E, Hooper L, Lupo AR, Market PS, Guinan PE, Stephan K, Fox NI, Svoma BM. 2014. Localized Climate and Surface Energy Flux Alterations across an Urban Gradient in the Central U.S. Energies, 7: 1770-1791.

Hubbart JA, and Zell C. 2013. Considering streamflow trend analyses uncertainty in urbanizing watersheds: a base flow case study in the central United States. Earth Interactions, 17(5): 1-28.

Hubbart JA, Muzika R-M, Huang D, Robinsond A. 2011. Bottomland hardwood forest influence on soil water consumption in an urban floodplain. Watershed Science Bulletin, (Fall 2011): 34-43.

Hubbart JA, Holmes J, Bowman G. 2010. Integrating science based decision making and TMDL allocations in urbanizing watersheds. The Watershed Science Bulletin, 01: 19-24.

Hubbart JA. 2011. Urban Floodplain Management. Stormwater, (September, 2011): 5663.

Jha M, Gassman PW, Secchi S, Gu R, Arnold J. 2004. Effect of watershed subdivision on swat flow, sediment, and nutrient predictions. JAWRA, 811-825.

Kirchner JW. 2003. A double paradox in catchment hydrology and geochemistry. Hydrological Processes, 17: 871-874.

Kutta E, Hubbart J. 2014. Improving understanding of microclimate heterogeneity within a contemporary plant growth facility to advance climate control and plant productivity. Journal of Plant Sciences, 2(5): 167-178. 
Lam QD, Schmalz B, Fohrer N. 2010. Modeling point and diffuse source pollution of nitrate in a rural lowland catchment using the SWAT model. Agricultural Water Management, 97(2): 317-325.

Lee M, Park G, Park M, Park J, Lee J, Kim S. 2010. Evaluation of non-point source pollution reduction by applying Best Management Practices using a SWAT model and QuickBird high resolution satellite imagery. Journal of Environmental Sciences, 22(6), 826-833.

McDonnell JJ. 2003. Where does water go when it rains? Moving beyond the variable source concept of rainfall-runoff response. Hydrological Processes, 17: 18691875 .

Miller D, Vandike J. 1997. Groundwater resources of Missouri. Missouri Department of Natural Resources Division of Geology and Land Survey Water Resources Rep., 46., $136 \mathrm{pp}$.

Moriasi DN, Arnold JG, Van Liew MW, Bingner RL, Harmel RD, Veith TL. 2007. Model evaluation guidelines for systematic quantification of accuracy in watershed simulations. Transactions of the ASABE, 50(3): 885-900.

Neitsch, SL, Arnold JG, Kiniry JR, Williams JR, and King KW. 2005. Soil and Water Assessment Tool Theoretical Documentation: Version2005, Texas Water Resources Institute, College Station, TX.

Phillips JD. 2003. Evolutionary geomorphology: thresholds and nonlinearity in landform response to environmental change. Hydrology and Earth System Sciences, 10: 731-742.

Saleh A, Du B. 2004. Evaluation of SWAT and HSPF within BASINS program for the upper North Bosque River watershed in central Texas. Transactions of the $A S A B E, 47(4):$ 1039-1049.

Srinivasan R, Zhang X, Arnold JG. 2010. SWAT ungauged: Hydrological budget and crop yield predictions in the Upper Mississippi River basin. Transactions of the $A S A B E$, 53(5): 1533-1546.

Svoboda M, LeComte D, Hayes M, Heim R, Gleason K, Angel J, Rippey B, Tinker R, Palecki M, Stooksbury D, Miskus D, Stephens S. 2002. The drought monitor. Bulletin of the American Meteorological Society, 83(8): 1181-1190.

Turtola E, Kemppainen E. 2008. Nitrogen and phosphorus losses in surface runoff and drainage water after application of slurry and mineral fertilizer to perennial grass ley. Agricultural and Food Science, 7(5-6), 569-581.

United States Census Bureau (USCB). 2014. U.S. Census Bureau: State and County Quick Facts. Available on line at: http://quickfacts.census.gov/qfd/states/29000.html 
U.S. Environmental Protection Agency (USEPA). 2002. Guidance for quality assurance project plans for modeling. EPA QA/G-5M. Report EPA/240/R-02/007.

Washington, D.C.: U.S. EPA, Office of Environmental Information.

Walsh CJ, Roy AH, Feminella JW, Cottingham PD, Groffman PM, Morgan II RP. 2005. The urban stream syndrome: current knowledge and the search for a cure, Journal of the North American Benthological Society, 24(3): 706-723.

White KL, Chaubey I. 2005. Sensitivity analysis, calibration, and validations for a multisite and multivariable SWAT model. JAWRA, 41(5): 1077 - 1089.

Zhang Z, Wagener T, Reed P, Bhushan R. 2008. Reducing uncertainty in predictions in ungauged basins by combining hydrologic indices regionalization and multiobjective optimization. Water Resources Research, 44(12).

Zeiger SJ, Hubbart JA. 2015a. Quantifying urban stormwater temperature surges: A central US watershed study. Hydrology, 2(4): 193-209; DOI:

10.3390/hydrology2040193

Zeiger SJ, Hubbart JA. 2015b. Nested-Scale Nutrient Yields from a Mixed-Land-Use Urbanizing Watershed. Hydrological Processes, 30(10): 1475-1490; DOI: 10.1002/hyp.10716 


\section{CHAPTER V \\ CONCLUSIONS AND SYNTHESIS}

\section{Summary}

Excessive suspended sediment (SS) and nutrient loading remain the most pervasive water quality problem globally and yet, despite progress, nonpoint-source process understanding remains relatively poor in watersheds with mixed-land use practices (Howarth et al., 1996; Carpenter et al., 1998; Clark et al., 1999; Baffaut et al., 2009; Lerch et al., 2015a). The need for science-based mitigation strategies aimed at reducing nonpoint-source pollutant loading from urbanizing catchments will likely increase given the current increasing trends in global population and urban growth (Rabotyagov et al., 2014). In fact, multiple authors have stressed the need for strategic planning of long-term action plans designed to conserve valuable water resources and associated aquatic natural resource commodities. Government and public incentive to reduce SS and nutrient loading is stimulated, in part, by the estimated $\$ 2.2$ billion spent annually on the recovery of threatened and endangered species, drinking water, lakefront property values, and losses in recreational use in the United States (Dodds et al., 2008). Clearly, there is a need to reduce SS and nutrient loading because soil and water resources are vital to human health. However, the effects of natural and anthropogenic impacts on SS and nutrient loading continue to confound water quality management attempts to quantify, target, and reduce non-point sources of pollution in mixed-land use watersheds (Cheviron et al., 2014).

The nested-scale study design used in this investigation serves as a useful model used to target nonpoint-source pollutants in watersheds with mixed-land use 
characteristics. Partitioning the watershed into multiple sub-basins each with different dominant land uses helped target critical source areas where management efforts could be focused to reduce sediment and nutrient yields. Additionally, the study design was wellsuited for ungauged model performance assessment to ensure accurate SWAT model simulations of pollutant loading throughout the entire watershed and not merely at the watershed outlet. The study design was an effective approach considering resources (e.g. time, money, and raw materials) can be wasted on management plans based on inaccurate land use-pollutant relationships and potentially unrealistic model-generated waste load allocations.

The overall objective of this research was to quantify spatio-temporal SS and nutrient regimes using a nested-scale experimental watershed study design. Subobjectives were to quantify relationships in land use and a) suspended sediment concentrations, and b) nutrient concentrations in the study catchment, and c) validate SWAT model estimations of monthly streamflow, sediment, and nutrients in a rapidly urbanizing mixed-land use watershed of the central USA.

\section{Land-Use and Suspended Sediment Loading}

Relationships in land use and suspended sediment were quantified using four years of observed water quality data collected using a nested-scale experimental watershed design in a rapidly urbanizing mixed-land use watershed of the central USA.

Suspended sediment concentrations were significantly $\left(R^{2}=0.577 ; p=0.001\right)$ dependent on annual total precipitation, and cumulative percent total forested, agricultural, and urban land uses. Median suspended sediment concentrations decreased by $60 \%$ from the agricultural headwaters to the rural/urban interface, and increased by $98 \%$ as urban land 
use increased. There were also significant $(p<0.024)$ temporal trends in FWC's across monthly, seasonally, and annual time scales. Most notably, FWC's were greatest during May with differences in median monthly FWCs ranging from $46.4 \mathrm{mg} \mathrm{L}^{-1}$ (April and May) to $257.01 \mathrm{mg} \mathrm{L}^{-1}$ (May and October). Sediment yields also ranged with precipitation from $16.1 \mathrm{t} \mathrm{km}^{-2}$ year $^{-1}$ at Site \#Site \#2 during 2012 (year of drought), to $313.0 \mathrm{t} \mathrm{km}^{-2}$ year $^{-1}$ at Site \#Site \#3 during 2010 (record setting wet year). The differences in annual sediment yields were significant $(p<0.008)$ temporally, but not spatially [(i.e. between sites $(p>0.05)]$. Overall, sediment yields were $54 \%, 80 \%$, and $87 \%$ greater than sediment yields from the Ohio River, the Upper Mississippi River, and the Missouri River basins, respectively. In the current study, relatively large sediment yields were attributed to high runoff rates from claypan soils in the headwaters, agricultural land use, and impervious surfaces. This is justifiable considering results from regional water quality studies (Baffaut et al., 2015; Lerch et al., 2015a; Sadler et al., 2015). Results indicated a need for best management practices to reduce terrestrial sources of SS yields from row crop and newly developing residential land use areas in HCW considering the observed relationships between land-use and pollutant loading in this study. Additionally, channel (e.g. channel incision and bank losses) sources of sediment need to be reduced in urbanizing sub-basins to conserve water quality.

\section{Land-Use and Nutrient Loading}

An objective of this study was to quantify relationships in land use and nutrients (i.e. TP-P, $\mathrm{NO}_{3}-\mathrm{N}, \mathrm{NO}_{2}-\mathrm{N}, \mathrm{NH}_{4}-\mathrm{N}$, and TIN-N) with four years of observed water quality data collected using a nested-scale experimental watershed design in a rapidly urbanizing mixed-land-use watershed of the central USA. Significant $(p<0.001)$ differences in 
observed median nutrient concentrations $\left(\mathrm{NH}_{3}-\mathrm{N}, \mathrm{NO}_{3}-\mathrm{N}\right.$, TIN-N, and TP-P) were observed at agricultural Site \#Site \#1 compared to all other sites (with the exception of nitrite) presumably due to the observed significant $(p<0.044)$ land use-nutrient concentration relationships. Observed TP-P and $\mathrm{NH}_{3}-\mathrm{N}$ levels were high at urban sites. For example, TP was significantly $(p<0.001)$ greater at Site \#Site \#5 where maximum TP-P exceeded $1.1 \mathrm{mg} \mathrm{L}^{-1}$, and $\mathrm{NH}_{3}-\mathrm{N}$ concentrations exceeded $1.5 \mathrm{mg} \mathrm{L}^{-1}$ at urban Site \#Site \#3. Also notable, percent differences in annual FWCs of inorganic $\mathrm{N}$ were greatest during 2012 (year of drought) and least during 2010 (record setting wet year) indicating decreased nutrient attenuation during wet years. Additionally, a source - sink effect was observed where preceding year (i.e. antecedent) annual precipitation increased the explained variance in nutrient yields by 4 to $19 \%\left(R^{2}>0.72 ; p<0.001\right)$. Median $\mathrm{NH}_{3}-\mathrm{N}$ yields $\left(0.742 \mathrm{~kg} \mathrm{ha}^{-1} \mathrm{yr}^{-1}\right)$ and TP-P yields $\left(0.979 \mathrm{~kg} \mathrm{ha}^{-1} \mathrm{yr}^{-1}\right)$ were large for the region likely due to a combination of claypan soils, crop $\mathrm{N}$ fertilizer and livestock in the agricultural subbasins (Sites \#1 and \#2), and impervious surfaces, wastewater and lawn N fertilizers in urban areas (Sites \#3, \#4and \#5). Results indicated a need for effective management plans designed to reduce nutrient pollution in mixed-land use catchments. Modeling Suspended Sediment and Nutrient Loading

Soil water assessment tool (SWAT) model estimations of monthly streamflow, sediment, and nutrients (i.e. TP-P, $\mathrm{NO}_{3}-\mathrm{N}, \mathrm{NO}_{2}-\mathrm{N}, \mathrm{NH}_{4}-\mathrm{N}$, and $\mathrm{TIN}$ ) were validated using four-years of water quantity and quality data collected from multiple gauging sites in a rapidly urbanizing mixed-land use watershed of the central USA. Uncalibrated SWAT model simulations of monthly stream flow were at least satisfactory. However, uncalibrated simulations of sediment, and nutrients [i.e. TP-P (NSE $\leq-13.0), \mathrm{NO}_{3}-\mathrm{N}$ 
(NSE $\leq-1.2)$ and TIN-N (NSE $\leq 0.09)]$ were unsatisfactory. Model performance improved after the model was calibrated to stream flow (NSE $>0.66$ ), sediment (NSE $>0.52)$, and nutrients [TP-P (NSE $>0.62), \mathrm{NO}_{3}-\mathrm{N}(\mathrm{NSE} \leq 0.73)$ and $\left.\mathrm{TIN}-\mathrm{N}(\mathrm{NSE} \leq 0.66)\right]$ using data collected from multiple gauging sites during the calibration period, but validation results were less accurate for monthly stream flow (NSE>0.61), sediment (NSE $>0.47$ ), and nitrogen $\left[\mathrm{NO}_{3}-\mathrm{N}(\mathrm{NSE}>0.26)\right.$ and TIN-N $\left.(\mathrm{NSE}>0.20)\right]$ when calibration parameters were not adjusted to observed data. These results highlighted the value of using long-term high-resolution multi-constituent data sets collected at multiple gauging sites to evaluate, calibrate, and validate continuous process-based watershed-scale hydrologic models.

When relationships between observed and simulated stream flow were quantified, the slope of the best fit line ranged between 0.62 at Site \#1 to 0.49 at Site \#5 indicating peak flows were underestimated (especially in urban sub-basins) which lead to underestimations of sediment and nutrients during extreme events when stage increased over bankfull. Combining a short-term storm event model [e.g. the dynamic watershed simulation model (DWSM)] with SWAT may improve SWAT estimates of peak flow (Borah et al., 2006), and thus, estimates of sediment and nutrient loads, considering short-term storm event models like DWSM are known for more accurate simulations of peak flow in comparision to long-term hydrologic models like SWAT (Borah et al., 2006; Borah and Berah 2003a, b). DWSM simulations of peak flow are more accurate than SWAT because DWSM has more realistic water routing routines that do not neglect surface and subsurface flow between HRU's within a sub-basin (Borah et al., 2006). However, a balance must be achieved between increased spatial complexity and ease-ofuse of the SWAT model (Gassman et al., 2007). 
Most model users often do not have sufficient observed data to calibrate the SWAT model such as accomplished in this work. While the SWAT model has been shown to simulate yearly stream flow (Srinivasan et al., 2010) and monthly stream flow at a rating of satisfactory (NSE > 0.5), the sediment and chemical routines will need to be improved before the model meets the satisfactory threshold proposed by Moriasi et al., (2007). Perhaps the most important improvement emerging from this SWAT model assessment was the need for algorithms that simulate terrestrial loading of $\mathrm{NO}_{2}-\mathrm{N}$ and $\mathrm{NH}_{4}-\mathrm{N}$ to the stream network because model outputs of $\mathrm{NO}_{2}-\mathrm{N}$ and $\mathrm{NH}_{4}-\mathrm{N}$ were greatly underestimated pre- and post-calibration. Until terrestrial inputs of $\mathrm{NO}_{2}-\mathrm{N}$ and $\mathrm{NH}_{4}-\mathrm{N}$ are loaded into the stream network during the land phase, simulated $\mathrm{NO}_{2}-\mathrm{N}$ and $\mathrm{NH}_{4}-\mathrm{N}$ data can be lumped with $\mathrm{NO}_{3}-\mathrm{N}$ for TIN-N.

\section{Synthesis of Land Use and Pollutant Loading}

\section{Background}

Environmental flows describe the timing and quantity of flow (i.e. the flow regime) necessary to sustain the ecological health of receiving waters (Arlington et al., 2006). Environmental flow requirements are standards set to maintain a natural flow regime and thereby promote aquatic ecosystem health, protect ecosystem services, and secure valuable water resources for use (Poff et al., 2010). A review of the literature by Poff et al., (2010) showed most of the environmental flow studies to date include investigations of flow regimes altered by hydropower dams, impoundments, and water extractions for irrigation that can substantially modify flow regimes. However, studies are on the rise involving mitigating the effects of land use (particularly urbanization) on flow regimes to meet environmental flow objectives (Walsh et al., 2012; Fletcher et al., 
2006), and representatives of regulatory agencies (e.g. United States Environmental Protection Agency) are presenting methodology specifically for developing environmental flow recommendations in urbanizing catchments (Mohamoud and Kraemer, 2008). Interest is shifting toward land use effects on environmental flows due to rapid development of watersheds with increasing human populations.

Rapid urbanization and agricultural development has altered stream flow regimes, and the current pace of impairment exceeds management efforts globally (Carlisle et al., 2010; Poff and Zimmerman, 2010). Deforestation for agricultural and urban expansion has reduced canopy interception of precipitation, soil infiltration, and evapotranspiration thereby increasing surface runoff, and stream flow volume (Carlisle et al., 2010). Flow regimes have also been altered by increased impervious surfaces that further reduce or eliminate soil infiltration, and increase the volume and velocity of surface runoff (Walsh et al., 2005a). Such alterations to stream flow regimes disrupt the historic transport regime of suspended sediments and nutrients (Carlisle et al., 2010). Aquatic ecosystem health is largely dependent on stream flow, suspended sediment, and nutrient regimes (Walsh et al., 2005a). It is therefore important to understand the effects of land use on flow and pollutant loading for effective management of aquatic ecosystem health (Arlington et al., 2010; Carlisle et al., 2010).

Authors of previous investigations showed urbanization causes flow alteration that affects physicochemical processes resulting in ecological impairment (Walsh et al., 2005a,b; Roy et al., 2005). Urbanization has been consistently linked to a flashy hydrograph response to precipitation events where "flashy hydrologic response" is described as more frequent flow events that consist of increased peak flow, reduced lag 
time to peak flow, and reduced time of concentration (Walsh et al., 2005a). Roy et al., (2005) noted more frequent high flows can cause ecological disturbance including, but not limited to, decreases in riparian and aquatic vegetation due to channel incision, scouring and bank erosion. Walsh et al., (2005b) stated that more frequent small flow events increase chemical delivery (including nutrients) to receiving waters. Increases in nutrient delivery can cause excessive algal growth in urban streams resulting in water quality impairment for a variety of uses, including but not limited to, protection of aquatic life and human health (Hatt et al., 2004). Wang et al., (2001) showed that connected impervious surfaces between 8 and $12 \%$ of total watershed area resulted in major changes in stream conditions including bank erosion, base flow, fish density, species richness, diversity, and index of biotic integrity. Walsh et al., (2005b) showed the impacts of urban land use on stream flow (e.g. flashy hydrograph response to precipitation events) can be mitigated by disconnecting impervious surface conduits that were designed to shunt runoff directly into streams. Disconnecting impervious surfaces and diverting stormwater to areas with wetland and forested land cover can reduce the frequency of flow events and thus reduce the delivery of chemicals to receiving waters (Walsh et al., 2005b). Other research has supported the benefits of maintaining and reestablishing bottomland hardwood forests to attenuate floodwaters (Kellner and Hubbart, 2016a, b; Hubbart, 2011; Hubbart et al., 2011). Results from the literature indicate a need to redesign urban stormwater drainage systems with low impact design measures (e.g. bioretention cells) to restore near-natural stream flow regimes necessary to achieve environmental flow requirements in rapidly urbanizing watersheds like HCW. 
There is a need for focused hydrologic and water quality monitoring that captures the variability of flow to accurately quantify flow mediated pollutant loading (Letcher et al., 1999; Royer et al., 2006; Quilbe et al., 2006). Such information can be used to develop environmental flow recommendations necessary to protect ecological health and public interests of water resources. In the current work, four years of hydroclimate data and pollutant concentrations were observed. While total loads were quantified, and correlations between pollutants and land use were estimated, there remains a need to quantify land use relationships at different flow intervals in Hinkson Creek. Additionally, there remains a need to generate flow and load duration curves. Such information can be used to support development of environmental flow recommendations locally and regionally (Poff et al., 2010).

\section{Methods}

The objective of this section was to go beyond written objectives of the research (presented in preceding chapters) and provide a novel synthesis to better conclude the work. To this end, given the need for environmental and ecological flow analyses in Hinkson Creek, daily flow and load duration curves were generated as per methods used by Vogel and Fennessey (1994) where daily mean flow (or daily total load) is sorted in decreasing order from high to low flow, and then plotted against exceedance probability $P$ :

$$
P=100 *\left(\begin{array}{c}
M \\
n+1
\end{array}\right)
$$

where $M$ is the ranked position in the sorted list and $n$ is the number of daily samples.

Load duration curves were generated using numeric criteria established by Dodds et al., (1998) for trophic boundaries in temperate streams. Dodds et al., (1998) 
established the nutrient criteria using cumulative distributions of TN-N and TP-P data collected from more than 1,000 stream sites. Applying those methods, estimates of 0.075 $\mathrm{mg} \mathrm{L}^{-1} \mathrm{TP}-\mathrm{P}$ and $1.5 \mathrm{mg} \mathrm{L}^{-1} \mathrm{TN}-\mathrm{N}$ were attributed to the upper third of the cumulative distribution of nutrient values (the meso-eutrophic boundary), while $0.025 \mathrm{mg} \mathrm{L}^{-1} \mathrm{TP}-\mathrm{P}$ and $0.7 \mathrm{mg} \mathrm{L}^{-1} \mathrm{TN}-\mathrm{N}$ were attributed to the lower third of the cumulative distribution of nutrient values (the oligo-mesotrophic boundary) (Table 5.1). Given these criteria, nutrient concentrations of $0.075 \mathrm{mg} \mathrm{L}^{-1} \mathrm{TP}-\mathrm{P}$ and $1.5 \mathrm{mg} \mathrm{L}^{-1} \mathrm{TN}-\mathrm{N}$ may reduce nutrient enrichment and thus deter the occurrence of excessive benthic algae and suspended algae typically associated with eutrophic conditions. In-stream nutrient limits of $0.075 \mathrm{mg} \mathrm{L}^{-1}$ TP-P and $1.5 \mathrm{mg} \mathrm{L}^{-1} \mathrm{TN}-\mathrm{N}$ have been implemented by Missouri Department of Natural Resources (MDNR) to reduce the frequency of algal blooms in compliance with water quality standards (WQS) for Missouri Streams. Hinkson Creek has been listed as impaired for WQS set to keep waters free from "substances in sufficient amounts to cause the formation of putrescent, unsightly or harmful bottom deposits or prevent full maintenance of beneficial uses", and "substances in sufficient amounts to cause unsightly color or turbidity, offensive odor or prevent full maintenance of beneficial uses" (MDNR, 2011). Therefore, the numeric criteria presented in Table 5.1 were deemed suitable numeric criteria for generating load duration curves in this research. 
Table 5.1. Estimated eutrophic and mesotrophic threshold concentrations for total ammonium $\left(\mathrm{NH}_{3}-\mathrm{N}\right)$, nitrite $\left(\mathrm{NO}_{2}-\mathrm{N}\right)$, nitrate $\left(\mathrm{NO}_{3}-\mathrm{N}\right)$, total inorganic nitrogen (TIN-N), total nitrogen (TN-N), total phosphorus (TP-P), suspended sediment (SS) for Hinkson Creek, USA.

\begin{tabular}{|c|c|c|}
\hline Element $^{\dagger \S}$ & $\begin{array}{l}\text { Eutrophic Threshold } \\
\left(\mathrm{mg} \mathrm{L}^{-1}\right)\end{array}$ & $\begin{array}{l}\text { Mesotrophic Threshold } \\
\left(\mathrm{mg} \mathrm{L}^{-1}\right)\end{array}$ \\
\hline $\mathrm{NH}_{3}-\mathrm{N}$ & 0.114 & 0.053 \\
\hline $\mathrm{NO}_{2}-\mathrm{N}$ & 0.055 & 0.026 \\
\hline $\mathrm{NO}_{3}-\mathrm{N}$ & 0.731 & 0.341 \\
\hline TIN-N & 0.900 & 0.420 \\
\hline TN-N & 1.500 & 0.700 \\
\hline TP-P & 0.075 & 0.025 \\
\hline $\mathrm{SS}^{\delta}$ & 11.60 & 0.900 \\
\hline
\end{tabular}

"Eutrophic and Mesotrophic thresholds for TN-N and TP-P were derived from Dodds et. al., (1998).

${ }^{\S}$ Thresholds for $\mathrm{N}$ species were estimated as a fraction of the TN-N threshold according to observed percent contributions of each $\mathrm{N}$ species to TIN-N, and percent contributions of TIN-N to TN-N derived from a calibrated application of the Soil and Water Assessment Tool for the study stream.

${ }^{\delta}$ SS thresholds were estimated using linear relationships between observed SS and TP-P data from the current work.

Once the flow and load duration curves were generated, descriptive statistics (minimum, median, and maximum) of daily flow and pollutant loading were calculated for five flow intervals including high flow (0-10\%), moist condition (10-40\%), mid-range flows (40-60\%), dry condition (60-90\%), and low flow (90-100\%) observed at five gauging sites located in Hinkson Creek. The percent of total pollutant loading was also calculated for each flow interval. Additionally, stepwise multiple linear regression analyses were performed [as per methods used by Lerch et al., (2015b)] to clarify relationships between cumulative percent land use (i.e. urban, forested, agricultural, wetland land use land cover data derived from the 2011 National Land Cover Dataset), and drainage area (derived from a 30m Digital Elevation Model) with median daily flow and pollutant yields observed during each flow interval used in this research. Results from flow and load duration curves, percent of total pollutant loading, and stepwise 
multiple linear regression analyses are displayed in tables and figures in this synthesis section.

Results

Daily flow (Table 5.2) and load duration analyses (Tables 5.3 to 5.8) consisted of multiple flow intervals including high flows (0-10\%), moist conditions (10-40\%), midrange flows (40-60\%), dry conditions (60-90\%), and low flows (90-100\%) observed at the five Hinkson Creek gauging sites used in this study. Pollutant loads ranged across three orders of magnitude for nutrient loads, and four orders of magnitude for suspended sediments during the high flow interval when nearly all of the total pollutant loads were transported (e.g. $98.8 \%$ of suspended sediments, $92.1 \%$ of TIN-N, and $94.5 \%$ of TP-P loads) (Table 5.9). There was also a general trend for the percent of total pollutant loads to increase from Sites \#1 to \#5 during moist conditions as average discharge increased from $0.1 \mathrm{~m}^{3} \mathrm{~s}^{-1}$ at Site \#1 to $1.0 \mathrm{~m}^{3} \mathrm{~s}^{-1}$ at Site \#5 (Tables 5.3 to 5.8). While less than $0.1 \%$ suspended sediments and less than 1.0\% TP-P were transported during mid-range conditions, greater than $1.0 \%$ of $\mathrm{NO}_{3}-\mathrm{N}$ was transported during mid-range condition at Sites \#1 and \#5 (Table 5. 9). Greater than $1.0 \%$ of $\mathrm{NO}_{3}-\mathrm{N}$ was also transported during dry conditions at Site \#1(Table 5. 9). 
Table 5.2. Summary of statistics from flow duration curves showing stream flow in cubic meters per second $\left(\mathrm{m}^{3} \mathrm{~s}^{-1}\right)$ for five flow intervals including high flow $(0-10 \%)$, moist condition (10-40\%), mid-range flows (40-60\%), dry condition (60-90\%), and low flow (90-100\%) observed at five gauging sites located in Hinkson Creek watershed, USA.

\begin{tabular}{lllllll}
\hline $\begin{array}{l}\text { Flow } \\
\text { Interval }\end{array}$ & Statistic & Site \#1 & Site \#2 & $\begin{array}{l}\text { Site \#3 } \\
\left(\mathrm{m}^{3} \mathrm{~s}^{-1}\right)\end{array}$ & Site \#4 & Site \#5 \\
\hline High & Min & 0.3 & 0.4 & 1.6 & 3.0 & 3.4 \\
Flow & Median & 1.0 & 1.5 & 5.0 & 6.9 & 9.5 \\
$0-10 \%$ & Max & 48.0 & 64.1 & 66.5 & 141.2 & 239.0 \\
\hline Moist & Min & 0.1 & 0.1 & 0.2 & 0.4 & 0.5 \\
Condition & Median & 0.1 & 0.1 & 0.4 & 1.0 & 1.0 \\
10-40\% & Max & 0.3 & 0.4 & 1.6 & 3.0 & 3.4 \\
\hline Mid- & Min & 0.1 & 0.0 & 0.1 & 0.2 & 0.3 \\
Range & Median & 0.1 & 0.0 & 0.1 & 0.2 & 0.4 \\
40-60\% & Max & 0.1 & 0.1 & 0.2 & 0.4 & 0.5 \\
\hline Dry & Min & 0.0 & 0.0 & 0.0 & 0.0 & 0.2 \\
Condition & Median & 0.1 & 0.0 & 0.0 & 0.1 & 0.2 \\
$60-90 \%$ & Max & 0.1 & 0.0 & 0.1 & 0.2 & 0.3 \\
\hline Low & Min & 0.0 & 0.0 & 0.0 & 0.0 & 0.1 \\
Flow & Median & 0.0 & 0.0 & 0.0 & 0.0 & 0.1 \\
90-100\% & Max & 0.0 & 0.0 & 0.0 & 0.0 & 0.2 \\
\hline
\end{tabular}


Table 5.3. Summary of statistics from suspended sediment load duration curves showing loads in metric tons per day $\left(\mathrm{t} \mathrm{day}^{-1}\right)$ for five flow intervals including high flow $(0-10 \%)$, moist condition (10-40\%), mid-range flows (40-60\%), dry condition (60-90\%), and low flow (90-100\%) observed at five gauging sites located in Hinkson Creek watershed, USA.

\begin{tabular}{lllllll}
\hline $\begin{array}{l}\text { Flow } \\
\text { Interval }\end{array}$ & Statistic & Site \#1 & Site \#2 & $\begin{array}{l}\text { Site \#3 } \\
\left(\mathrm{t} \mathrm{day}^{-1}\right)\end{array}$ & Site \#4 & Site \#5 \\
\hline High & Min & 0.2754 & 0.4102 & 1.1792 & 2.4444 & 6.2347 \\
Flow & Median & 7.0346 & 15.279 & 52.020 & 85.010 & 204.48 \\
$0-10 \%$ & Max & 4848.4 & 3840.0 & 5499.7 & 8317.5 & 10427.9 \\
\hline Moist & Min & 0.0016 & 0.0028 & 0.0112 & 0.0449 & 0.1121 \\
Condition & Median & 0.0872 & 0.0761 & 0.3511 & 1.0455 & 1.8430 \\
10-40\% & Max & 2.4607 & 3.3331 & 9.5212 & 65.975 & 92.905 \\
\hline Mid- & Min & 0.0024 & 0.0016 & 0.0046 & 0.0070 & 0.0097 \\
Range & Median & 0.0175 & 0.0132 & 0.0266 & 0.0705 & 0.2260 \\
40-60\% & Max & 0.2221 & 0.3792 & 1.2037 & 1.3293 & 3.0292 \\
\hline Dry & Min & 0.0019 & 0.0003 & 0.0010 & 0.0018 & 0.0249 \\
Condition & Median & 0.0135 & 0.0033 & 0.0050 & 0.0116 & 0.0980 \\
60-90\% & Max & 0.4600 & 0.0455 & 0.1219 & 0.1801 & 0.7408 \\
\hline Low & Min & 0.0015 & 0.0004 & 0.0005 & 0.0006 & 0.0263 \\
Flow & Median & 0.0091 & 0.0031 & 0.0014 & 0.0033 & 0.0789 \\
90-100\% & Max & 0.1444 & 0.0118 & 0.0688 & 0.0257 & 0.4123 \\
\hline
\end{tabular}


Table 5.4. Summary of statistics from total ammonium $\left(\mathrm{NH}_{3}-\mathrm{N}\right)$ load duration curves showing loads in kilograms per day $\left(\mathrm{kg} \mathrm{day}^{-1}\right)$ for five flow intervals including high flow (0-10\%), moist condition (10-40\%), mid-range flows (40-60\%), dry condition (60-90\%), and low flow (90-100\%) observed at five gauging sites located in Hinkson Creek watershed, USA.

\begin{tabular}{lllllll}
\hline $\begin{array}{l}\text { Flow } \\
\text { Interval }\end{array}$ & Statistic & Site \#1 & Site \#2 & $\begin{array}{l}\text { Site \#3 } \\
\left(\mathrm{kg} \mathrm{day}^{-1}\right)\end{array}$ & Site \#4 & Site \#5 \\
\hline High & Min & 1.758 & 1.869 & 7.764 & 11.819 & 22.934 \\
Flow & Median & 16.159 & 22.321 & 71.769 & 107.310 & 153.867 \\
$0-10 \%$ & Max & 1530.815 & 1639.098 & 2188.073 & 4914.772 & 7787.807 \\
\hline Moist & Min & 0.149 & 0.160 & 0.114 & 0.760 & 1.252 \\
Condition & Median & 0.752 & 0.620 & 2.055 & 4.934 & 6.849 \\
10-40\% & Max & 12.024 & 12.662 & 23.024 & 53.480 & 62.643 \\
\hline Mid- & Min & 0.083 & 0.083 & 0.186 & 0.349 & 0.925 \\
Range & Median & 0.307 & 0.182 & 0.452 & 1.020 & 2.256 \\
40-60\% & Max & 2.113 & 2.084 & 18.067 & 7.087 & 24.196 \\
\hline Dry & Min & 0.077 & 0.021 & 0.048 & 0.068 & 0.503 \\
Condition & Median & 0.224 & 0.053 & 0.137 & 0.247 & 1.140 \\
$60-90 \%$ & Max & 3.534 & 0.523 & 2.197 & 4.060 & 7.425 \\
\hline Low & Min & 0.021 & 0.017 & 0.013 & 0.015 & 0.255 \\
Flow & Median & 0.117 & 0.025 & 0.052 & 0.069 & 0.591 \\
90-100\% & Max & 0.357 & 0.142 & 0.235 & 0.207 & 2.050 \\
\hline
\end{tabular}


Table 5.5. Summary of statistics from nitrite $\left(\mathrm{NO}_{2}-\mathrm{N}\right)$ load duration curves showing loads in kilograms per day $\left(\mathrm{kg} \mathrm{day}^{-1}\right)$ for five flow intervals including high flow (0-10\%), moist condition (10-40\%), mid-range flows (40-60\%), dry condition (60-90\%), and low flow (90-100\%) observed at five gauging sites located in Hinkson Creek watershed, USA.

\begin{tabular}{lllllll}
\hline $\begin{array}{l}\text { Flow } \\
\text { Interval }\end{array}$ & Statistic & Site \#1 & Site \#2 & $\begin{array}{l}\text { Site \#3 } \\
\left(\mathrm{kg} \mathrm{day}^{-1}\right)\end{array}$ & Site \#4 & Site \#5 \\
\hline High & Min & 0.820 & 1.401 & 2.513 & 9.524 & 11.336 \\
Flow & Median & 7.390 & 11.853 & 36.791 & 62.690 & 91.103 \\
$0-10 \%$ & Max & 754.682 & 1057.661 & 1353.323 & 2536.656 & 3987.221 \\
\hline Moist & Min & 0.054 & 0.046 & 0.034 & 0.493 & 0.687 \\
Condition & Median & 0.343 & 0.325 & 1.142 & 3.019 & 3.479 \\
10-40\% & Max & 5.067 & 3.315 & 11.933 & 42.228 & 36.447 \\
\hline Mid- & Min & 0.005 & 0.029 & 0.075 & 0.140 & 0.346 \\
Range & Median & 0.133 & 0.081 & 0.234 & 0.463 & 0.933 \\
40-60\% & Max & 1.166 & 1.037 & 2.196 & 8.247 & 11.872 \\
\hline Dry & Min & 0.035 & 0.008 & 0.023 & 0.021 & 0.111 \\
Condition & Median & 0.098 & 0.030 & 0.058 & 0.112 & 0.512 \\
$60-90 \%$ & Max & 1.417 & 0.289 & 1.013 & 0.538 & 1.703 \\
\hline Low & Min & 0.007 & 0.006 & 0.006 & 0.009 & 0.087 \\
Flow & Median & 0.026 & 0.013 & 0.014 & 0.019 & 0.233 \\
90-100\% & Max & 0.075 & 0.021 & 0.060 & 0.102 & 0.810 \\
\hline
\end{tabular}


Table 5.6. Summary of statistics from nitrate $\left(\mathrm{NO}_{3}-\mathrm{N}\right)$ load duration curves showing loads in kilograms per day $\left(\mathrm{kg} \mathrm{day}^{-1}\right)$ for five flow intervals including high flow $(0-10 \%)$, moist condition (10-40\%), mid-range flows (40-60\%), dry condition (60-90\%), and low flow (90-100\%) observed at five gauging sites located in Hinkson Creek watershed, USA.

\begin{tabular}{lllllll}
\hline $\begin{array}{l}\text { Flow } \\
\text { Interval }\end{array}$ & Statistic & Site \#1 & Site \#2 & $\begin{array}{l}\text { Site \#3 } \\
\left(\mathrm{kg} \mathrm{day}^{-1}\right)\end{array}$ & Site \#4 & Site \#5 \\
\hline High & Min & 9.443 & 6.334 & 21.923 & 94.538 & 149.906 \\
Flow & Median & 92.049 & 158.738 & 476.808 & 688.700 & 1047.635 \\
$0-10 \%$ & Max & 8731.535 & 9336.211 & 11054.996 & 19049.690 & 27588.178 \\
\hline Moist & Min & 1.072 & 1.186 & 2.550 & 6.160 & 5.812 \\
Condition & Median & 6.098 & 5.925 & 17.111 & 44.232 & 47.009 \\
10-40\% & Max & 32.047 & 57.450 & 148.820 & 291.433 & 349.095 \\
\hline Mid- & Min & 0.134 & 0.197 & 0.929 & 2.675 & 3.874 \\
Range & Median & 1.938 & 1.205 & 3.001 & 6.161 & 12.381 \\
40-60\% & Max & 21.236 & 16.116 & 22.848 & 62.260 & 79.527 \\
\hline Dry & Min & 0.443 & 0.117 & 0.210 & 0.331 & 2.314 \\
Condition & Median & 1.171 & 0.342 & 0.903 & 1.657 & 5.734 \\
$60-90 \%$ & Max & 15.005 & 4.184 & 8.362 & 13.271 & 37.615 \\
\hline Low & Min & 0.108 & 0.098 & 0.083 & 0.076 & 1.185 \\
Flow & Median & 0.355 & 0.128 & 0.184 & 0.231 & 2.312 \\
90-100\% & Max & 1.039 & 0.287 & 1.123 & 1.014 & 10.033 \\
\hline
\end{tabular}


Table 5.7. Summary of statistics from total inorganic nitrogen (TIN-N) load duration curves showing loads in kilograms per day $\left(\mathrm{kg} \mathrm{day}^{-1}\right)$ for five flow intervals including high flow (0-10\%), moist condition (10-40\%), mid-range flows (40-60\%), dry condition $(60-90 \%)$, and low flow (90-100\%) observed at five gauging sites located in Hinkson Creek watershed, USA.

\begin{tabular}{lllllll}
$\begin{array}{l}\text { Flow } \\
\text { Interval }\end{array}$ & Statistic & Site \#1 & Site \#2 & $\begin{array}{l}\text { Site \#3 } \\
\left(\mathrm{kg} \mathrm{day}^{-1}\right)\end{array}$ & Site \#4 & Site \#5 \\
\hline High & Min & 16.232 & 12.939 & 35.473 & 124.169 & 194.301 \\
Flow & Median & 120.986 & 199.115 & 614.566 & 863.379 & 1306.464 \\
$0-10 \%$ & Max & 10986.544 & 12032.969 & 14338.376 & 25155.847 & 39363.206 \\
\hline Moist & Min & 1.538 & 1.756 & 3.118 & 8.052 & 8.466 \\
Condition & Median & 7.385 & 7.150 & 20.761 & 53.064 & 56.327 \\
$10-40 \%$ & Max & 45.544 & 73.108 & 168.796 & 346.455 & 448.185 \\
\hline Mid- & Min & 0.501 & 0.363 & 1.357 & 3.355 & 5.797 \\
Range & Median & 2.475 & 1.531 & 3.882 & 8.102 & 15.983 \\
40-60\% & Max & 22.620 & 17.963 & 24.761 & 68.805 & 86.854 \\
\hline Dry & Min & 0.371 & 0.171 & 0.300 & 0.437 & 3.287 \\
Condition & Median & 1.510 & 0.431 & 1.079 & 2.043 & 7.852 \\
$60-90 \%$ & Max & 17.385 & 4.610 & 9.212 & 14.441 & 42.068 \\
\hline Low & Min & 0.146 & 0.127 & 0.117 & 0.099 & 1.742 \\
Flow & Median & 0.492 & 0.168 & 0.250 & 0.323 & 3.331 \\
90-100\% & Max & 1.131 & 0.351 & 1.419 & 1.176 & 12.034 \\
\hline
\end{tabular}


Table 5.8. Summary of statistics from total phosphorus (TP-P) load duration curves showing loads in kilograms per day $\left(\mathrm{kg} \mathrm{day}^{-1}\right)$ for five flow intervals including high flow (0-10\%), moist condition (10-40\%), mid-range flows (40-60\%), dry condition (60-90\%), and low flow (90-100\%) observed at five gauging sites located in Hinkson Creek watershed, USA.

\begin{tabular}{lllllll}
\hline $\begin{array}{l}\text { Flow } \\
\text { Interval }\end{array}$ & Statistic & Site \#1 & Site \#2 & $\begin{array}{l}\text { Site \#3 } \\
\left(\mathrm{kg} \mathrm{day}^{-1}\right)\end{array}$ & Site \#4 & Site \#5 \\
\hline High & Min & 2.495 & 2.222 & 8.513 & 3.242 & 23.786 \\
Flow & Median & 19.476 & 29.840 & 89.337 & 130.466 & 211.569 \\
$0-10 \%$ & Max & 2711.700 & 2574.022 & 3805.873 & 6245.711 & 10460.399 \\
\hline Moist & Min & 0.046 & 0.043 & 0.060 & 0.014 & 0.016 \\
Condition & Median & 0.860 & 0.764 & 2.411 & 5.291 & 7.256 \\
10-40\% & Max & 9.608 & 16.504 & 29.425 & 93.496 & 162.894 \\
\hline Mid- & Min & 0.019 & 0.011 & 0.006 & 0.009 & 0.030 \\
Range & Median & 0.346 & 0.162 & 0.430 & 0.814 & 2.002 \\
40-60\% & Max & 2.735 & 1.371 & 3.137 & 19.208 & 33.680 \\
\hline Dry & Min & 0.009 & 0.000 & 0.001 & 0.008 & 0.060 \\
Condition & Median & 0.253 & 0.057 & 0.091 & 0.162 & 1.098 \\
$60-90 \%$ & Max & 2.674 & 0.467 & 1.995 & 2.283 & 12.991 \\
\hline Low & Min & 0.020 & 0.002 & 0.002 & 0.007 & 0.096 \\
Flow & Median & 0.079 & 0.033 & 0.028 & 0.036 & 0.550 \\
90-100\% & Max & 0.327 & 0.173 & 0.140 & 0.255 & 3.792 \\
\hline
\end{tabular}


Table 5.9. Percent of total pollutant loading during multiple flow intervals including high flow (0-10\%), moist condition (10-40\%), mid-range flows (40-60\%), dry condition (60$90 \%$ ), and low flow (90-100\%) observed at five gauging sites located in Hinkson Creek watershed, USA. Total ammonium $\left(\mathrm{NH}_{3}-\mathrm{N}\right)$, nitrite $\left(\mathrm{NO}_{2}-\mathrm{N}\right)$, nitrate $\left(\mathrm{NO}_{3}-\mathrm{N}\right)$, total inorganic nitrogen (TIN-N), total nitrogen (TN-N), total phosphorus (TP-P), suspended sediment (SS).

\begin{tabular}{|c|c|c|c|c|c|c|c|}
\hline Element & Flow Interval & Site \#1 & Site \#2 & $\begin{array}{l}\text { Site \#3 } \\
(\%)\end{array}$ & Site \#4 & Site \#5 & Average \\
\hline \multirow[t]{5}{*}{ SS } & High Flow & 99.6 & 99.6 & 99.1 & 98.2 & 97.6 & 98.8 \\
\hline & Moist Conditions & 0.4 & 0.3 & 0.9 & 1.8 & 2.2 & 1.1 \\
\hline & Mid-Range & 0.0 & 0.0 & 0.0 & 0.1 & 0.1 & 0.1 \\
\hline & Dry Conditions & 0.0 & 0.0 & 0.0 & 0.0 & 0.1 & 0.0 \\
\hline & Low Flow & 0.0 & 0.0 & 0.0 & 0.0 & 0.0 & 0.0 \\
\hline \multirow[t]{5}{*}{$\mathrm{NH}_{3}-\mathrm{N}$} & High Flow & 94.6 & 96.6 & 94.1 & 91.7 & 90.7 & 93.5 \\
\hline & Moist Conditions & 3.5 & 2.7 & 5.0 & 7.1 & 7.0 & 5.1 \\
\hline & Mid-Range & 0.9 & 0.4 & 0.7 & 0.8 & 1.3 & 0.8 \\
\hline & Dry Conditions & 0.9 & 0.2 & 0.2 & 0.3 & 0.9 & 0.5 \\
\hline & Low Flow & 0.1 & 0.0 & 0.0 & 0.0 & 0.1 & 0.1 \\
\hline \multirow[t]{5}{*}{$\mathrm{NO}_{2}-\mathrm{N}$} & High Flow & 95.9 & 96.8 & 94.7 & 92.1 & 92.0 & 94.3 \\
\hline & Moist Conditions & 2.8 & 2.7 & 4.6 & 7.0 & 6.4 & 4.7 \\
\hline & Mid-Range & 0.6 & 0.4 & 0.5 & 0.6 & 0.9 & 0.6 \\
\hline & Dry Conditions & 0.6 & 0.2 & 0.2 & 0.2 & 0.6 & 0.4 \\
\hline & Low Flow & 0.1 & 0.0 & 0.0 & 0.0 & 0.1 & 0.0 \\
\hline \multirow[t]{5}{*}{$\mathrm{NO}_{3}-\mathrm{N}$} & High Flow & 93.6 & 95.0 & 92.1 & 88.3 & 89.1 & 91.6 \\
\hline & Moist Conditions & 4.1 & 4.1 & 6.8 & 10.4 & 8.7 & 6.8 \\
\hline & Mid-Range & 1.1 & 0.7 & 0.8 & 1.0 & 1.3 & 1.0 \\
\hline & Dry Conditions & 1.1 & 0.3 & 0.3 & 0.3 & 0.8 & 0.5 \\
\hline & Low Flow & 0.1 & 0.0 & 0.0 & 0.0 & 0.1 & 0.0 \\
\hline \multirow[t]{5}{*}{ TIN-N } & High Flow & 93.9 & 95.4 & 92.6 & 89.1 & 89.5 & 92.1 \\
\hline & Moist Conditions & 4.0 & 3.8 & 6.4 & 9.6 & 8.3 & 6.4 \\
\hline & Mid-Range & 1.1 & 0.6 & 0.8 & 0.9 & 1.3 & 0.9 \\
\hline & Dry Conditions & 1.0 & 0.2 & 0.3 & 0.3 & 0.8 & 0.5 \\
\hline & Low Flow & 0.1 & 0.0 & 0.0 & 0.0 & 0.1 & 0.0 \\
\hline \multirow[t]{5}{*}{ TP-N } & High Flow & 95.8 & 97.0 & 95.2 & 92.3 & 92.0 & 94.5 \\
\hline & Moist Conditions & 2.7 & 2.5 & 4.2 & 6.9 & 6.3 & 4.5 \\
\hline & Mid-Range & 0.6 & 0.3 & 0.4 & 0.6 & 0.9 & 0.6 \\
\hline & Dry Conditions & 0.8 & 0.1 & 0.2 & 0.2 & 0.7 & 0.4 \\
\hline & Low Flow & 0.1 & 0.0 & 0.0 & 0.0 & 0.1 & 0.0 \\
\hline
\end{tabular}

Results from stepwise multiple linear regression analyses showed significant relationships between land-use, flow and pollutant transport (Table 5.10). The models 
accounted for much of the explained variance in flow at high flow $\left(R^{2}=98.2 \% ; p=0.001\right)$, moist conditions $\left(R^{2}=94.3 \% ; p=0.004\right)$, and mid-range $\left(R^{2}=92.9 \% ; p=0.005\right)$ flow intervals. Flow during the high flow interval was dependent on cumulative percent urban land use (positive correlate), flow during moist conditions was dependent on cumulative percent wetland land use (negative correlate), and flow during the mid-range flow interval was dependent on cumulative percent forested land use (negative correlate). However, no significant relationships $(p<0.05)$ were observed during dry conditions, or low flow intervals. Suspended sediment yields were dependent on cumulative percent forested land use (negative correlate) during high flow, moist conditions, and mid-range flow intervals $\left(R^{2}>81.6 ; p<0.23\right) . \mathrm{NH}_{3}-\mathrm{N}$ yields were dependent on cumulative percent urban land use (positive correlate) during high flow and moist conditions, and cumulative percent forested land use (negative correlate) during the mid-range flow interval $\left(R^{2}>78.7 .6 ; p<0.29\right) . \mathrm{NO}_{2}-\mathrm{N}, \mathrm{NO}_{3}-\mathrm{N}$ and $\mathrm{TIN}-\mathrm{N}$ yields were dependent on cumulative percent urban land use (positive correlate) during the high flow interval, cumulative percent wetland land use (negative correlate) during moist conditions, and cumulative percent forested and urban land uses during the mid-range flow interval $\left(R^{2}>75.7\right.$; $p<0.31)$. Finally, TP-P yields were dependent on cumulative percent urban land use (positive correlate) during high flow and moist conditions, and cumulative percent forested and wetland land uses during the mid-range flow interval $\left(R^{2}>82.7 ; p<0.21\right)$. 
Table 5.10. Stepwise multiple linear regression models for daily flow and pollutant yields at multiple flow intervals including high flow (0-10\%), moist condition (10-40\%), mid-range flows (40-60\%), dry condition (60-90\%), and low flow (90-100\%) observed at five gauging sites located in Hinkson Creek watershed, USA. Total ammonium $\left(\mathrm{NH}_{3}-\mathrm{N}\right)$, nitrite $\left(\mathrm{NO}_{2}-\mathrm{N}\right)$, nitrate $\left(\mathrm{NO}_{3}-\mathrm{N}\right)$, total inorganic nitrogen (TIN-N), total nitrogen (TN-N), total phosphorus (TP-P), suspended sediment (SS), $\mathrm{x}_{\mathrm{n}}$ is the independent variable, $\mathrm{b}$ is the $\mathrm{y}$-intercept, $\mathrm{m}_{\mathrm{n}}$ is the slope, and $\mathrm{R}^{2}$ is the coefficient of determination..

\begin{tabular}{|c|c|c|c|c|c|c|c|c|}
\hline \multirow{2}{*}{$\begin{array}{l}\text { Dependent } \\
\text { Variable }\end{array}$} & \multirow[t]{2}{*}{ Flow interval } & \multicolumn{2}{|c|}{ Independent } & \multicolumn{3}{|c|}{ Model equation } & \multirow[t]{2}{*}{$R^{2}$} & \multirow[t]{2}{*}{$p$-value } \\
\hline & & $x_{1}$ & $x_{2}$ & $b$ & $m_{1}$ & $m_{2}$ & & \\
\hline \multirow{5}{*}{$\begin{array}{l}\text { Flow } \\
\mathrm{m}^{3} \mathrm{~s}^{-1}\end{array}$} & High Flow & \%Urban & & -0.6231 & 0.387 & & 3823 & 0.001 \\
\hline & Moist Conditions & $\%$ Wetland & & 3.627 & -1.88 & & 94.30 & 0.004 \\
\hline & Mid-Range & $\%$ Forested & & 3.855 & -0.102 & & 92.90 & 0.005 \\
\hline & Dry Conditions & & & & & & & \\
\hline & Low Flow & & & & & & & \\
\hline \multirow{5}{*}{$\begin{array}{l}\text { SS } \\
\text { t ha }^{-1} \text { day }^{-1}\end{array}$} & High Flow & $\%$ Forested & & 901.70 & -23.8 & & 90.79 & 0.008 \\
\hline & Moist Conditions & $\%$ Forested & Area & 6.6850 & 0.00002 & & 99.93 & 0.022 \\
\hline & Mid-Range & $\%$ Forested & & 0.9484 & -0.0252 & & 81.60 & 0.023 \\
\hline & Dry Conditions & & & & & & & \\
\hline & Low Flow & & & & & & & \\
\hline \multirow{5}{*}{$\begin{array}{l}\mathrm{NH}_{3}-\mathrm{N} \\
\mathrm{kg} \mathrm{ha}^{-1} \text { day }^{-1}\end{array}$} & High Flow & $\%$ Urban & & 0.132000 & 0.02450 & & 78.70 & 0.029 \\
\hline & Moist Conditions & $\%$ Urban & & 0.001699 & 0.00122 & & 95.86 & 0.002 \\
\hline & Mid-Range & $\%$ Forested & & 0.088140 & -0.00230 & & 89.74 & 0.009 \\
\hline & Dry Conditions & & & & & & & \\
\hline & Low Flow & & & & & & & \\
\hline \multirow{5}{*}{$\begin{array}{l}\mathrm{NO}_{2}-\mathrm{N} \\
\mathrm{kg} \mathrm{ha}^{-1} \text { day }^{-1}\end{array}$} & High Flow & $\%$ Urban & & 0.04301 & 0.015688 & & 89.67 & 0.009 \\
\hline & Moist Conditions & $\%$ Wetland & & 0.05405 & -0.0266 & & 92.37 & 0.006 \\
\hline & Mid-Range & $\%$ Forested & $\%$ Urban & 0.07189 & -0.00187 & -0.00015 & 99.71 & 0.016 \\
\hline & Dry Conditions & & & & & & & \\
\hline & Low Flow & & & & & & & \\
\hline
\end{tabular}




\begin{tabular}{|c|c|c|c|c|c|c|c|c|}
\hline \multirow{5}{*}{$\begin{array}{l}\mathrm{NO}_{3}-\mathrm{N} \\
\mathrm{kg} \mathrm{ha}^{-1} \text { day }^{-1}\end{array}$} & High Flow & $\%$ Urban & & 0.7871 & 0.16793 & & 78.80 & 0.028 \\
\hline & Moist Conditions & $\%$ Wetland & & 0.7218 & -0.346 & & 92.72 & 0.006 \\
\hline & Mid-Range & $\%$ Forested & $\%$ Urban & -0.0262 & -0.00226 & & 99.16 & 0.033 \\
\hline & Dry Conditions & & & & & & & \\
\hline & Low Flow & & & & & & & \\
\hline \multirow{5}{*}{$\begin{array}{l}\text { TIN-N } \\
\mathrm{kg} \mathrm{ha}^{-1} \text { day }^{-1}\end{array}$} & High Flow & $\%$ Urban & & 1.0753 & 0.20681 & & 75.70 & 0.035 \\
\hline & Moist Conditions & $\%$ Wetland & & 0.8634 & -0.413 & & 92.56 & 0.006 \\
\hline & Mid-Range & $\%$ Forested & $\%$ Urban & 1.2665 & -0.03290 & -0.00277 & 99.30 & 0.031 \\
\hline & Dry Conditions & & & & & & & \\
\hline & Low Flow & & & & & & & \\
\hline \multirow{5}{*}{$\begin{array}{l}\text { TP-N } \\
\mathrm{kg} \mathrm{ha}^{-1} \text { day }^{-1}\end{array}$} & High Flow & $\%$ Urban & & 0.14180 & 0.03350 & & 82.70 & 0.021 \\
\hline & Moist Conditions & $\%$ Urban & & 0.00330 & 0.00124 & & 95.13 & 0.003 \\
\hline & Mid-Range & $\%$ Forested & $\%$ Urban & 0.22141 & -0.005768 & -0.0006212 & 97.30 & 0.013 \\
\hline & Dry Conditions & & & & & & & \\
\hline & Low Flow & & & & & & & \\
\hline
\end{tabular}




\section{Discussion}

Results from flow and load duration analyses (Figures 5.1 to 5.7) show the importance of water quality monitoring that captures the variability of pollutant loading during high flow periods (particularly for suspended sediments). Nearly all of the total pollutant loads were transported during the high flow interval (e.g. $98.8 \%$ of suspended sediments, $92.1 \%$ of TIN-N, and $94.5 \%$ of TP-P loads). However, the greatest

concentrations of $\mathrm{NO}_{3}-\mathrm{N}\left(5.01 \mathrm{mg} \mathrm{L}^{-1}\right)$ were observed at Site \#1 during moist conditions when stream flow at Site \#1 was $0.06 \mathrm{~m}^{3} \mathrm{~s}^{-1}$. In fact, as much as $11 \%$ of total $\mathrm{NO}_{3}-\mathrm{N}$ load was transported during moist to dry conditions in agreement with results published by other authors (Poor and McDonnell, 2007; Bernhardt et al., 2008; Birgand et al., 2014) who have also showed that $\mathrm{NO}_{3}-\mathrm{N}$ is transported with stormflow and base flow. The flow and load duration analyses conducted in the current work were used to quantify flow and pollutant transport regimes in HCW. Thus, the results from flow and load duration analyses would be useful for the development of environmental flow recommendations in HCW and similar mixed-use watersheds in the region. 


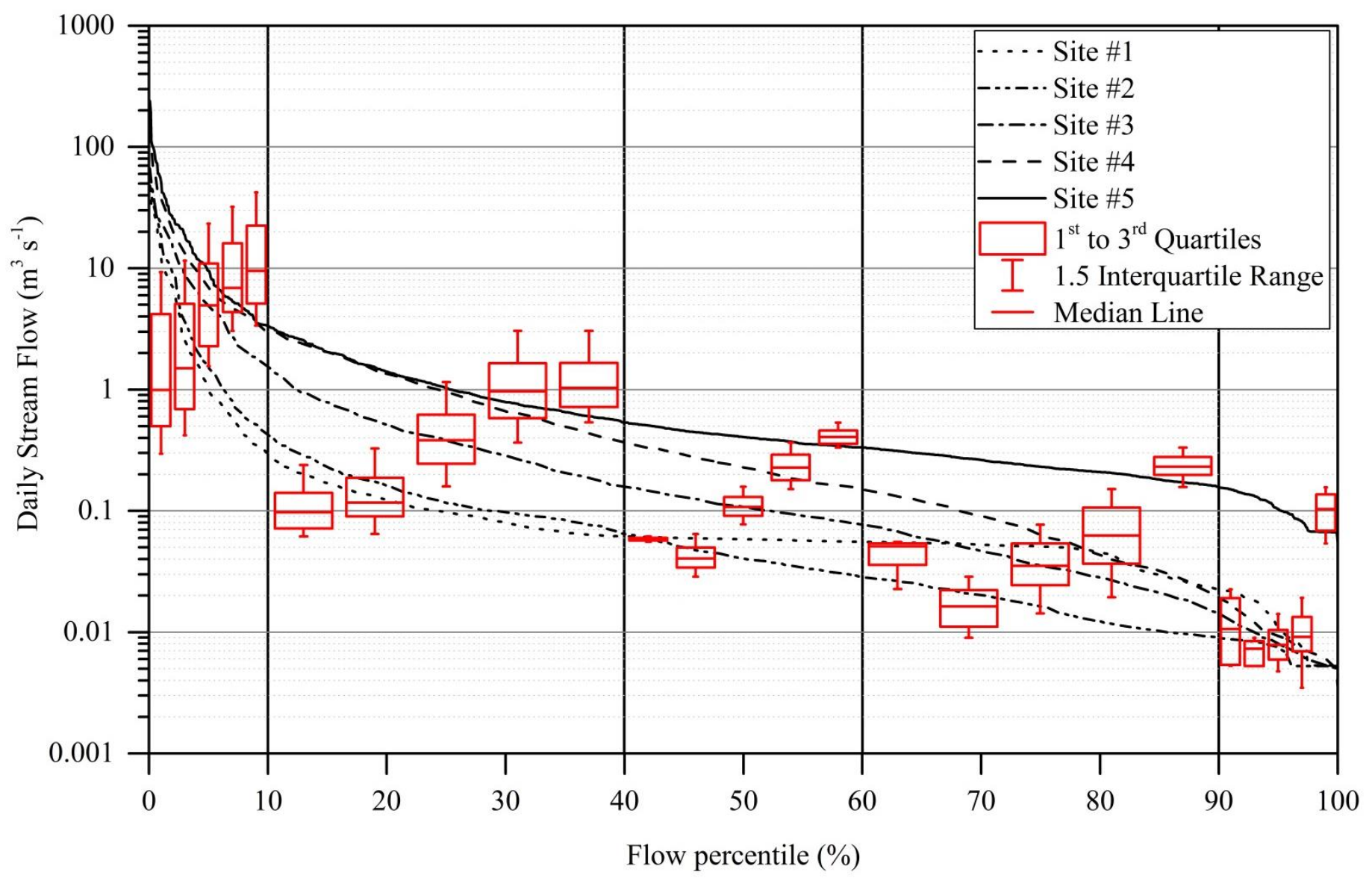

Figure 5.1. Daily flow duration curves with box and whisker plot for five flow intervals including high flow (0-10\%), moist condition (10-40\%), mid-range flows (40-60\%), dry condition (60-90\%), and low flow (90-100\%) observed at five gauging sites located in Hinkson Creek watershed, USA. The five sets of box and whisker plots (one set per flow interval) correspond to observed data collected at gauging Sites \#1 to \#5 from left to right. 


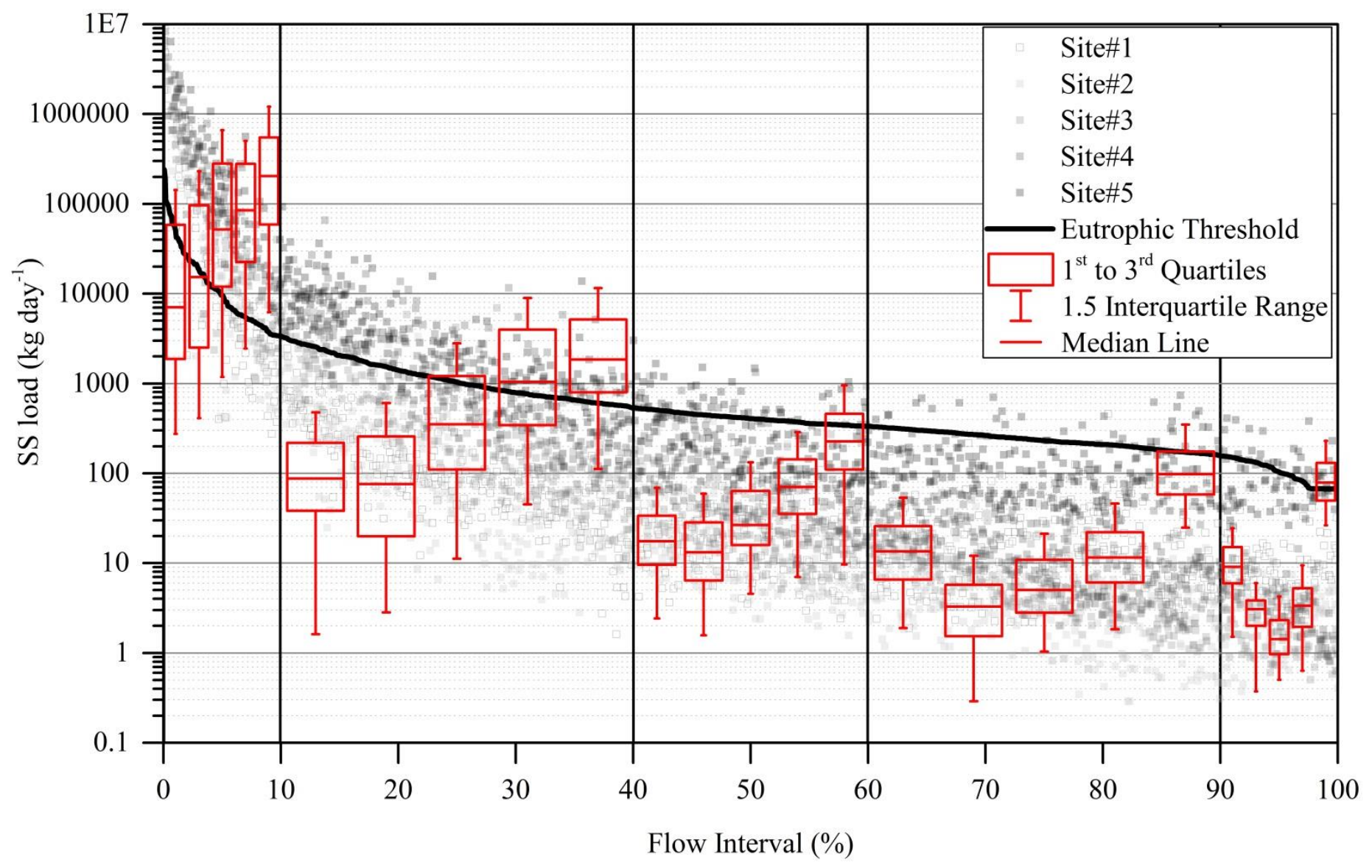

Figure 5.2. Daily suspended sediment load duration curves with box and whisker plot for five flow intervals including high flow (0-10\%), moist condition (10-40\%), mid-range flows (40-60\%), dry condition (60-90\%), and low flow (90-100\%) observed at five gauging sites located in Hinkson Creek watershed, USA. The eutrophic threshold was calculated for the downstream most gauging site (Site \#5). The five sets of box and whisker plots (one set per flow interval) correspond to observed data collected at gauging Sites \#1 to \#5 from left to right. 


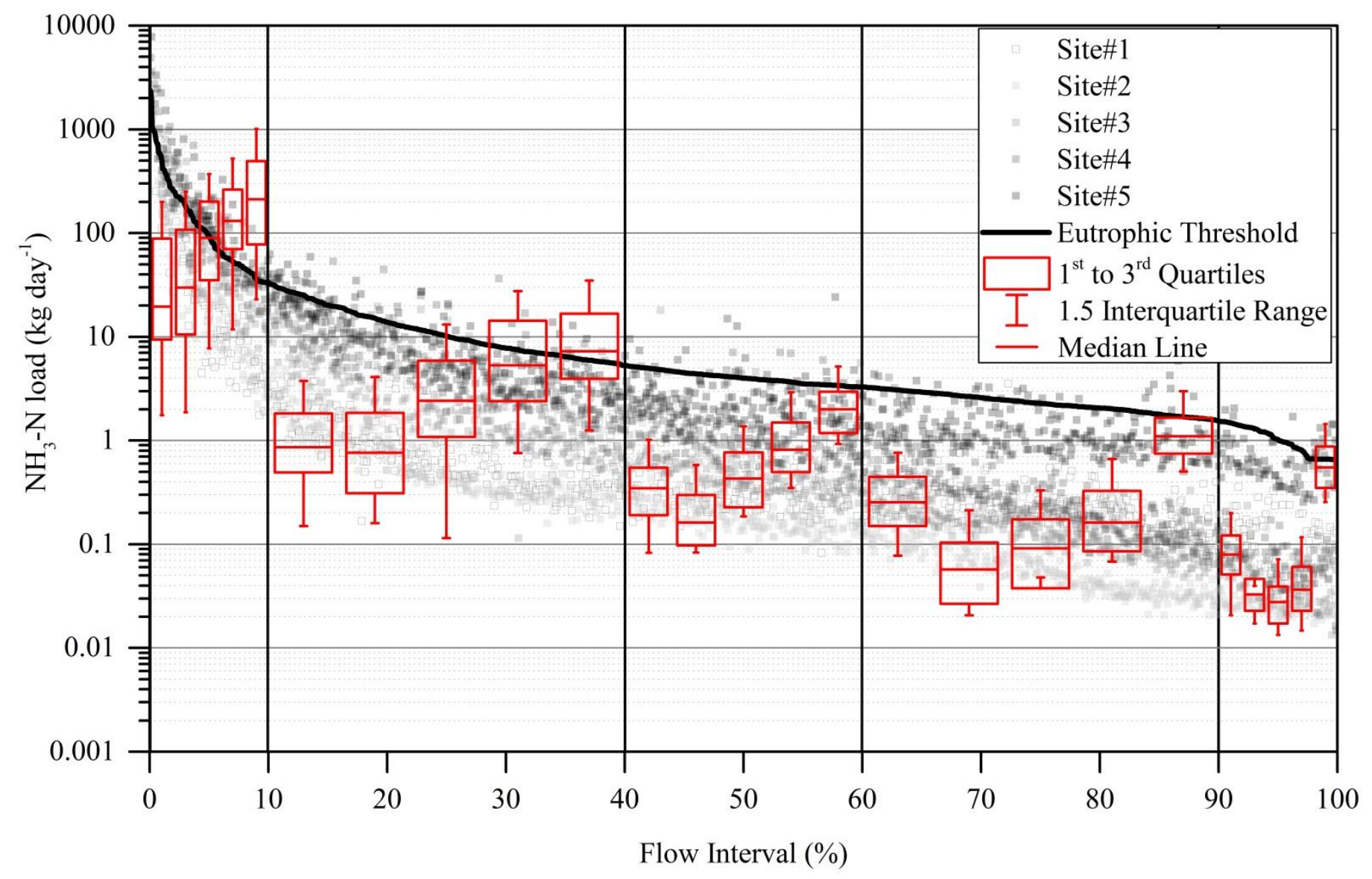

Figure 5.3. Daily total ammonium $\left(\mathrm{NH}_{3}-\mathrm{N}\right)$ load duration curves with box and whisker plot for five flow intervals including high flow (0-10\%), moist condition (10-40\%), mid-range flows (40-60\%), dry condition (60-90\%), and low flow (90-100\%) observed at five gauging sites located in Hinkson Creek watershed, USA. The eutrophic threshold was calculated for the downstream most gauging site (Site \#5). The five sets of box and whisker plots (one set per flow interval) correspond to observed data collected at gauging Sites \#1 to \#5 from left to right. 


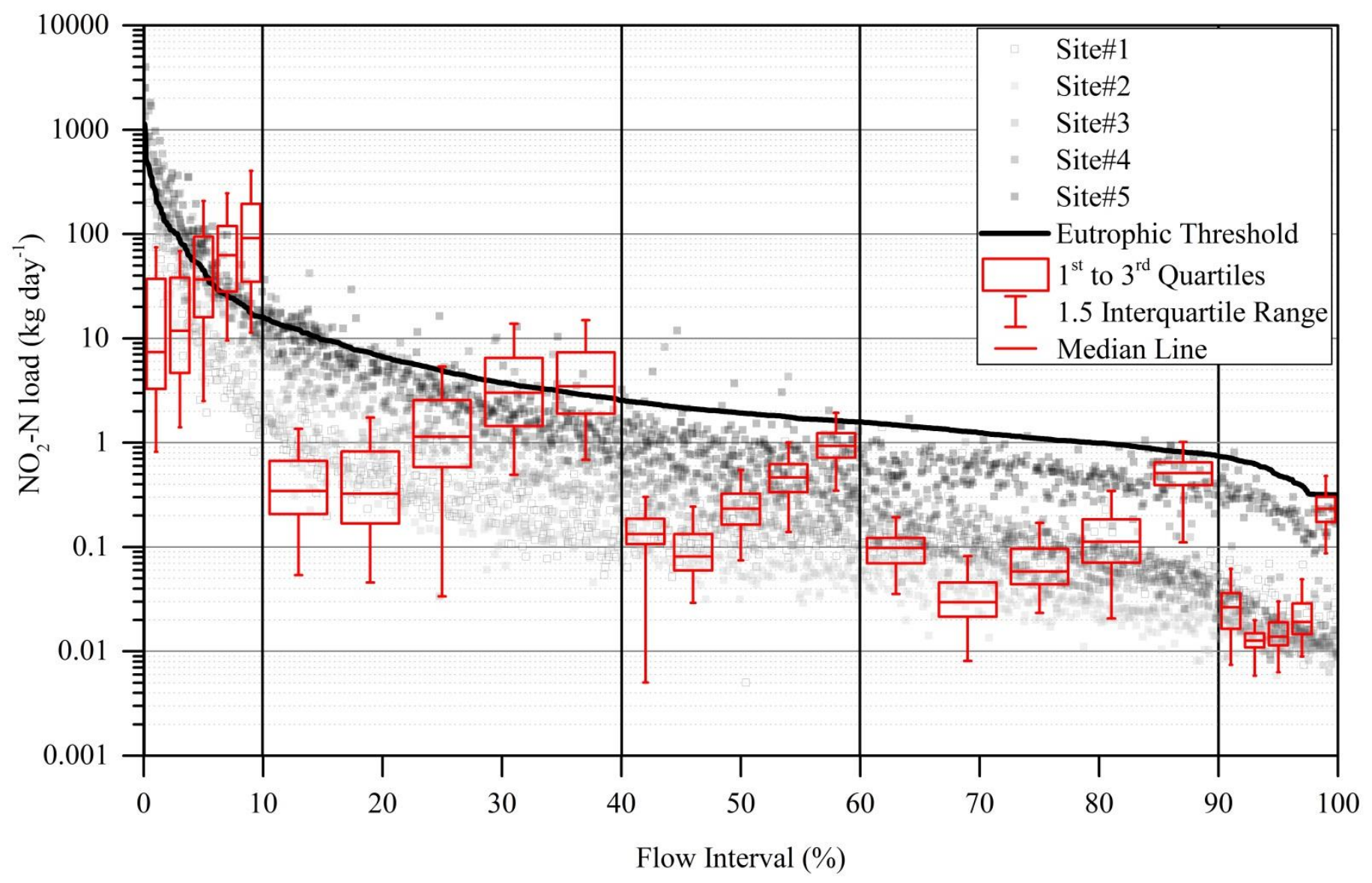

Figure 5.4. Daily nitrite $\left(\mathrm{NO}_{2}-\mathrm{N}\right)$ load duration curves with box and whisker plot for five flow intervals including high flow (0$10 \%$ ), moist condition (10-40\%), mid-range flows (40-60\%), dry condition (60-90\%), and low flow (90-100\%) observed at five gauging sites located in Hinkson Creek watershed, USA. The eutrophic threshold was calculated for the downstream most gauging site (Site \#5). The five sets of box and whisker plots (one set per flow interval) correspond to observed data collected at gauging Sites \#1 to \#5 from left to right. 


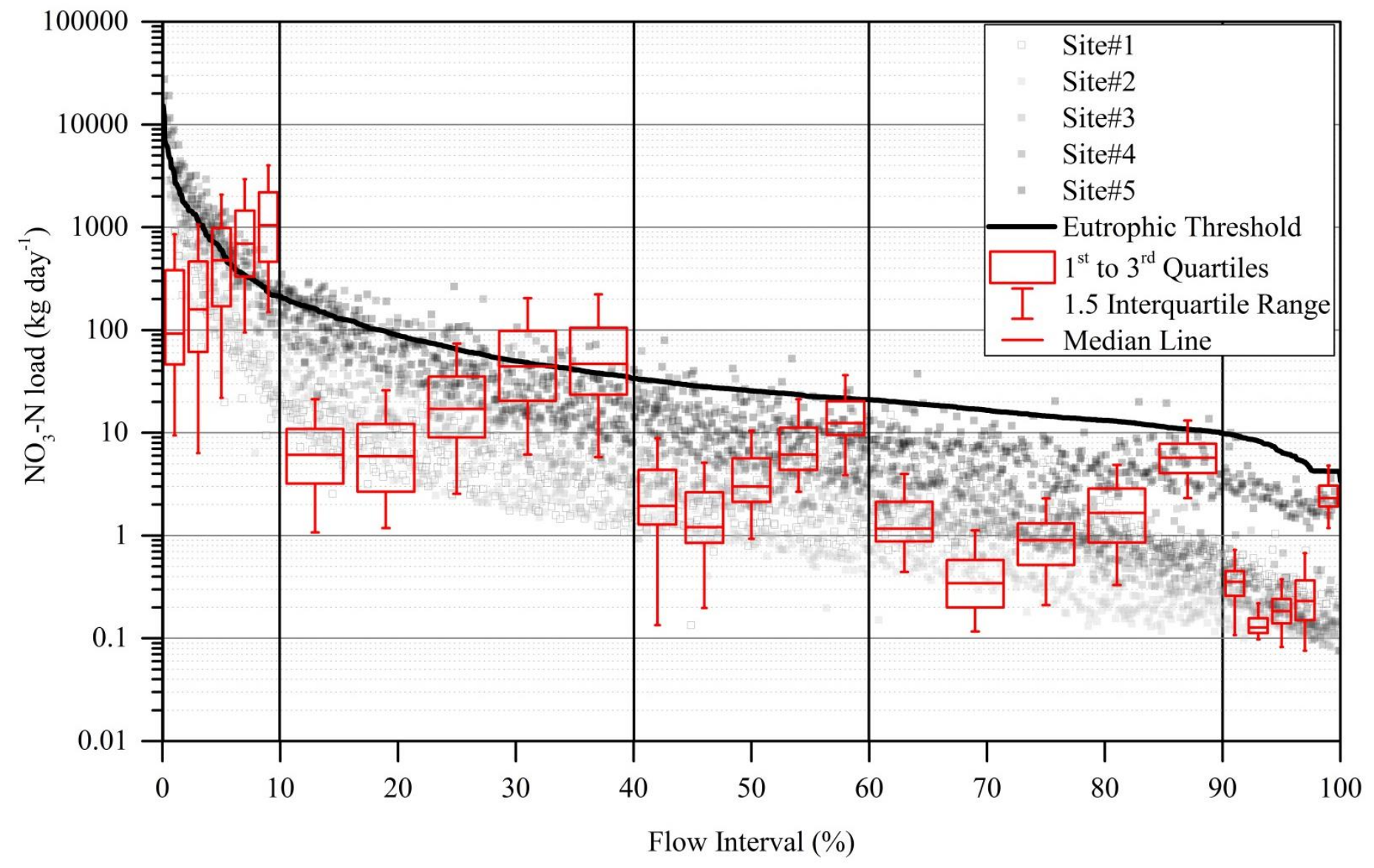

Figure 5.5. Daily nitrate $\left(\mathrm{NO}_{3}-\mathrm{N}\right)$ load duration curves with box and whisker plot for five flow intervals including high flow (0-10\%), moist condition (10-40\%), mid-range flows (40-60\%), dry condition (60-90\%), and low flow (90-100\%) observed at five gauging sites located in Hinkson Creek watershed, USA. The eutrophic threshold was calculated for the downstream most gauging site (Site \#5). The five sets of box and whisker plots (one set per flow interval) correspond to observed data collected at gauging Sites \#1 to \#5 from left to right. 


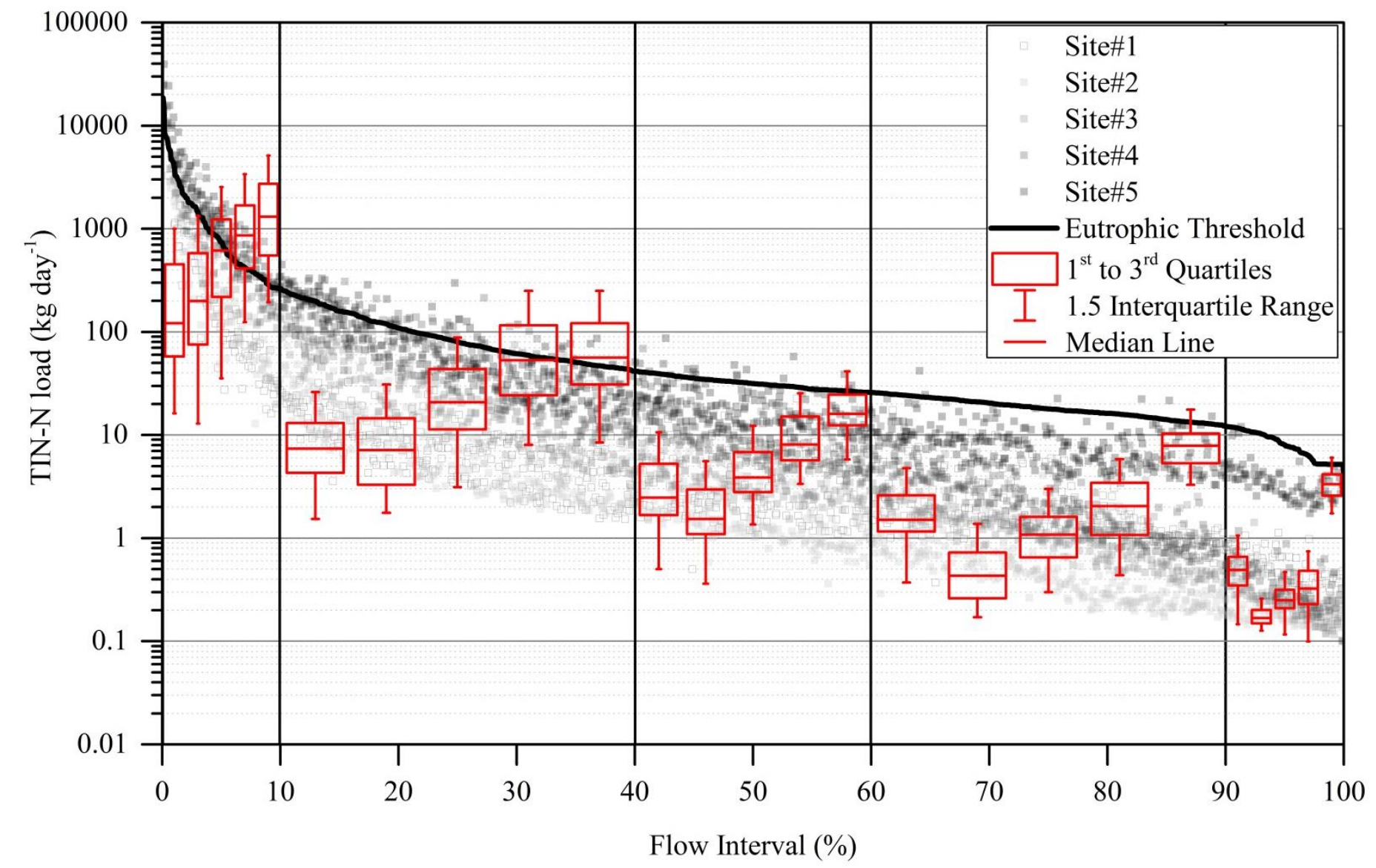

Figure 5.6. Daily total inorganic nitrogen (TIN-N) load duration curves with box and whisker plot for five flow intervals including high flow (0-10\%), moist condition (10-40\%), mid-range flows (40-60\%), dry condition (60-90\%), and low flow (90-100\%) observed at five gauging sites located in Hinkson Creek watershed, USA. The eutrophic threshold was calculated for the downstream most gauging site (Site \#5). The five sets of box and whisker plots (one set per flow interval) correspond to observed data collected at gauging Sites \#1 to \#5 from left to right. 


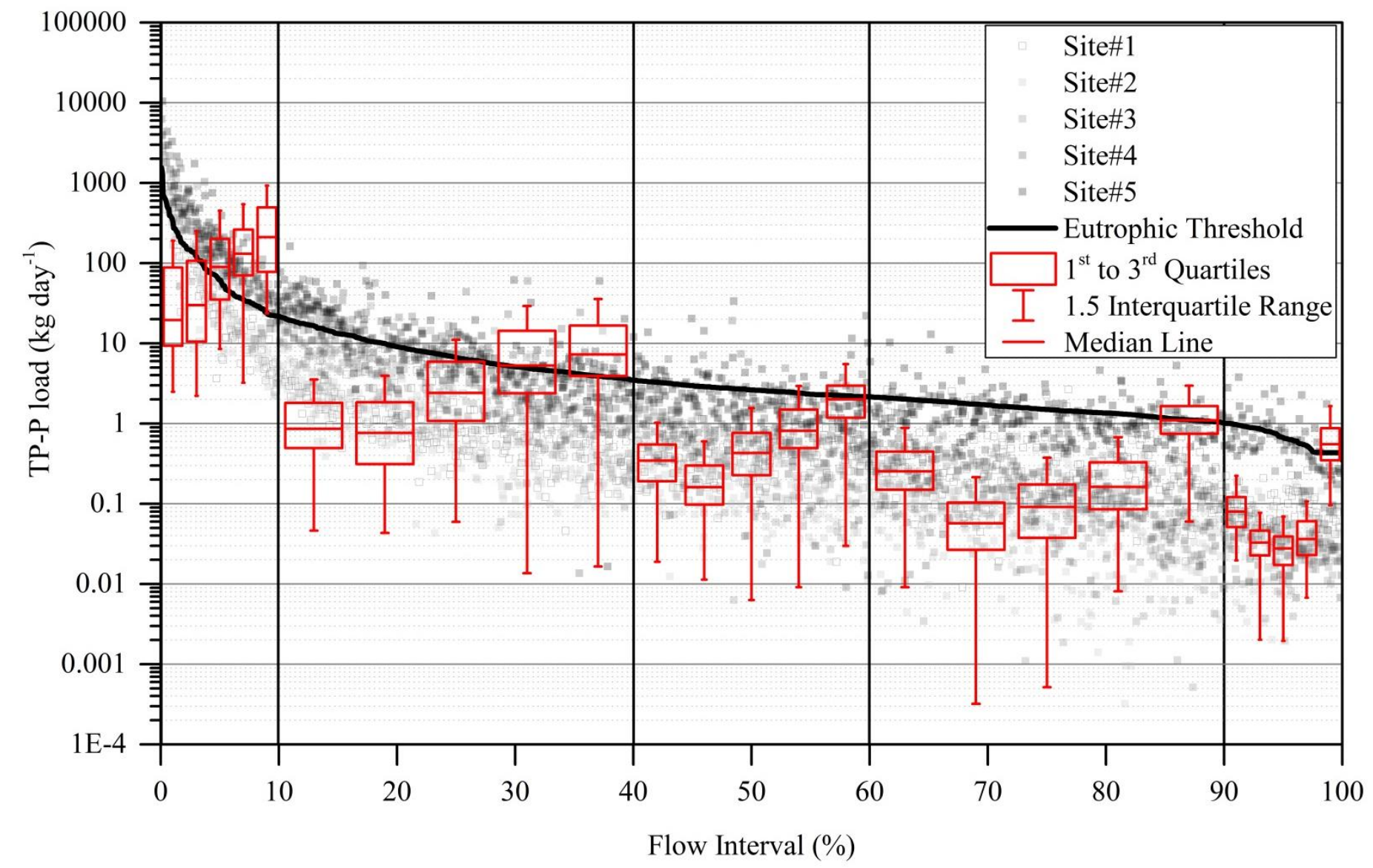

Figure 5.7. Daily total phosphorus (TP-P) load duration curves with box and whisker plot for five flow intervals including high flow (0-10\%), moist condition (10-40\%), mid-range flows (40-60\%), dry condition (60-90\%), and low flow (90-100\%) observed at five gauging sites located in Hinkson Creek watershed, USA. The eutrophic threshold was calculated for the downstream most gauging site (Site \#5). The five sets of box and whisker plots (one set per flow interval) correspond to observed data collected at gauging Sites \#1 to \#5 from left to right 
Examination of observed pollutant loading relative to established criteria for trophic boundaries in temperate streams developed by Dodds et al., (1998) showed the eutro-mesotrophic boundary was exceeded by a range of $37.8 \%\left(\mathrm{NO}_{3}-\mathrm{N}\right.$ at Site \#1) to 182.2\% (suspended sediment at Site \#5) for every constituent measured at all five gauging sites during the high flow interval in Hinkson Creek when median daily stream flow was $1.0,1.5,5.0,6.9$, and $9.5 \mathrm{~m}^{3} \mathrm{~s}^{-1}$ at Sites \#1 to \#5, respectively. The eutromesotrophic boundary was also exceeded by $7.7 \%$ (Site \#4) and 56.3\% (Site \#5) for suspended sediment, and by $30.6 \%$ (Site \#1), 1.0\% (Site \#2) and 8.3\% (Site \#5) for TP-P during moist conditions when median daily stream flow was $0.1,0.1,0.4,1.0$, and $1.0 \mathrm{~m}^{3}$ $\mathrm{s}^{-1}$ at Sites \#1 to \#5, respectively. However, the observed median daily pollutant loading did not exceed the load duration curve below the mid-range flow interval when median daily stream flow was $0.1,0.0,0.1,0.2$, and $0.4 \mathrm{~m}^{3} \mathrm{~s}^{-1}$ at Sites \#1 to \#5, respectively Thus, if the eutrophic threshold concentrations presented in Table 5.1 were used to develop environmental flow standards for Hinkson Creek, then flow mediated pollutant transport during the high flow interval would not meet environmental flow standards considering the observed data exceeded the load duration curve by more than $37.8 \%$ for every constituent in the current load duration analysis. Results from multiple linear regression modeling were used to link the observed pollutant loadings during the high flow interval (i.e. flows greater than $0.3,0.4,1.6,3.0$, and $3.4 \mathrm{~m}^{3} \mathrm{~s}^{-1}$ from Sites \#1 to \#5, respectively) to urban land use in $\mathrm{HCW}$.

Stepwise multiple linear regression models indicated a positive relationship between flow and percent urban land use where the slope $(m)$ of the best fit line was 
0.3870, and a negative relationship between flow and percent wetland land cover ( $m=-1.88)$, and forested land cover $(m=-0.2384)$ similar to other research (Allan, 2004; Meyer and Turner, 1994). Stepwise model fitting results also showed significant $(p<0.037)$ land use-pollutant transport relationships results in agreement with the literature where land use accounted for the majority of the explained variance in suspended sediment $\left(R^{2}>81.6 \%\right), \mathrm{NH}_{3}-\mathrm{N}\left(R^{2}>78.7 \%\right), \mathrm{NO}_{2}-\mathrm{N}\left(R^{2}>82.6 \%\right), \mathrm{NO}_{3}-\mathrm{N}$ $\left(R^{2}>75.1 \%\right)$, TIN-N $\left(R^{2}>74.8 \%\right)$, and TP-P $\left(R^{2}>82.7 \%\right)$ yields. For example, suspended sediment and nutrient loading usually decrease as cumulative percent of forested land cover increases, and cumulative percent urban land use increases (Meybek et al., 2003; Nelson and Booth, 2002; Schottler et al., 2014; Lamba et al., 2015). Urban land use can account for a small percentage of catchment area and still exert a disproportionately large influence on flow, suspended sediment and nutrient loading (Allan, 2004). Thus, the land-use relationships observed in the current work coupled with results from other studies show statistical relationships between land use and water quality that can be used to provide evidence of anthropic effects on water quality and thus ecological integrity in urbanizing mixed-use watersheds (Booth et al., 2004; Allan, 2004; Tong et al., 2002; Sponseller et al., 2001; Dauer et al., 2000; Meyer and Turner, 1994). However, caution should be used when relying on statistical models for predictions due to interacting impacts of natural (e.g. climate) and anthropogenic factors including, but not limited to, extreme climate coupled with legacy effects from prior human activities (Allan, 2004). Covariation between land use and other topographic variables (e.g. drainage area) may also affect linear regression analysis results (Allan, 2004). Additionally, non-linear 
responses between land use and pollutant loading may occur outside of the domain of input data (e.g. cumulative urban land use between 4 and $26 \%$ in the current work). Thus, the models presented in Table 5.10 may be useful tools for pollutant yield predictions in watersheds with similar climate, slope, roughness, soils, karst influence, vegetation, and land use practices within the domain of the input data used to fit the models. Overall, results from the current work show evidence of urban land use impacts stream flow and pollutant loading particularly during high flows (i.e. flows greater than $0.3,0.4,1.6,3.0$, and $3.4 \mathrm{~m}^{3} \mathrm{~s}^{-1}$ from Sites \#1 to \#5, respectively). There is a need to develop environmental flow requirements designed to reduce the delivery of suspended sediment, nitrogen and phosphorus to receiving waters in $\mathrm{HCW}$ and similar rapidly urbanizing watersheds.

\section{Recommendations for Future Work}

Excessive suspended sediment and nutrient loading (particularly TP) observed in HCW highlights a need for additional and ongoing studies in the region, and improved best management practices designed to reduce suspended sediment and nutrient loading from mixed-land use watersheds to receiving waters. Future work should focus on partitioning the amount of sediment and nutrients originating from overland and channel sources within each sub-basin. For example, the proportion of sediment and nutrients originating from the stream channel (i.e. the stream bed and banks) relative to overland areas may increase, decrease, or remain neutral with stream distance. However, stream channel contributions to SS and nutrients have not been directly measured at the watershed scale. Future hydrologic modeling work should be performed to quantify the 
amount of sediment and sediment bound nutrients originating from overland sources and from the stream channel. Event-based models should be used to quantify flow and pollutant loading during extreme events when stage increases over bankfull considering continuous-time models are notorious for underestimating flow and pollutant loading during extreme events. Results from future work will be useful information for local management with regards to the best location(s) (e.g. overland or stream channel) for BMPs implemented to reduce non-point source pollution in the study catchment.

A complete decoupling of the natural (e.g. climate, topography, soils, and geology) and anthropic (e.g. land use and land management practices) impacts to sediment and nutrient regimes was a limitation of the current work. Therefore, future work should be performed to incorporate the use of event-based and continuous-time hydrologic models to quantify the contribution of sediment and nutrients due to human impacts with a particular focus on land use related impacts to hydrograph response. Results will help land management develop improved management goals for individual catchments across the range of human disturbance regionally.

\section{Closing Comments}

Predicted increases in climate extremes (i.e. flooding and drought), deforestation, urbanization, and use of agrochemicals are linked to water security issues globally. In the central USA, the effects of a combination of crop $\mathrm{N}$ fertilizer and livestock manure in the agricultural areas, and wastewater and lawn $\mathrm{N}$ fertilizers in urban areas have been cited as the primary causes of eutrophication and resulting hypoxia in the Gulf of Mexico (Bernhardt et al., 2008; Lehman et al., 2009). Results from this work are in agreement 
with literature reviews (Walsh et al., 2005; Borah et al., 2006; Bernhardt et al., 2008) that show the greatest levels of nonpoint-source pollution are transported in response to large precipitation events. Natural and anthropogenic impacts to nonpoint-source loading projected to increase (Bernhardt et al., 2008), and therefore, best management practices and conservation measures needed to reduce nonpoint-source inputs into surface waters (Carpenter et al., 1998). However, there will be a need for long-term, broad-scale, and persistent efforts to conserve valuable soil and water resources globally (Rabalais et al., 2010). Physically-based watershed-scale hydrologic models like SWAT are useful resource conserving tools for large-scale mitigation efforts. However, additional quality long-term multi-constituent data sets collected from multiple nested gauging sites are needed to continue to test and develop hydrologic models for use in ungauged mixedland-use watersheds. The HCW nested-scale experimental watershed study has served as a laboratory for the study of the natural and anthropogenic impacts on water quantity and quality, and as a model for managers that need to target nonpoint-source pollution and validate ungauged hydrologic models in similar mixed-land use watersheds globally. 


\section{Literature Cited}

Allan JD. 2004. Landscapes and riverscapes: the influence of land use on stream ecosystems. Annual review of ecology, evolution, and systematics, 257-284.

Arthington AH, Bunn SE, Poff NL, Naiman RJ. 2006. The challenge of providing environmental flow rules to sustain river ecosystems. Ecological Applications, 16(4), 1311-1318.

Arthington ÁH, Naiman RJ, McClain ME, Nilsson C. 2010. Preserving the biodiversity and ecological services of rivers: new challenges and research opportunities. Freshwater Biology, 55(1), 1-16.

Baffaut, C., E.J. Sadler, and F. Ghidey. 2015. Long-term agroecosystem research in the Central Mississippi River Basin: Goodwater Creek Experimental Watershed flow data. Journal of Environmental Quality, 44:17-26. doi:10.2134/jeq2014.01.0008

Baffaut, C., E.J. Sadler, R.N. Lerch, and N.R. Kitchen. 2009. Nutrient sources and transport from the Goodwater Creek Experimental Watershed. Pap. 097150. Transactions of the ASABE, St. Joseph, MI.

Birgand F, Skaggs RW, Chescheir GM, Gilliam JW. 2007. Nitrogen removal in streams of agricultural catchments - a literature review. Critical Reviews in Environmental Science and Technology, 37: 381-487.

Bernhardt ES, Band LE, Walsh CJ, Berke PE. 2008. Understanding, managing, and minimizing urban impacts on surface water flux. Annals of the New York Academy of Sciences, 1134: 61-96.

Borah DK, Yagow G, Saleh A, Barnes PL, Rosenthal W, Krug EC, Hauck LM. 2006. Sediment and nutrient modeling for TMDL development and implementation. Transactions of the ASABE, 49(4): 967-986.

Booth DB, Karr JR, Schauman S, Konrad CP, Morley SA, Larson MG, Burges SJ. 2004. Reviving urban streams: Land use, hydrology, biology, and human behavior. JAWRA, 40(5): 1351-1364.

Bunn SE, Arthington AH. 2002. Basic principles and ecological consequences of altered flow regimes for aquatic biodiversity. Environmental management, 30(4), 492507.

Carpenter SR, Caraco NF, Correll DL, Howarth RW, Sharpley AN, Smith VH. 1998. Nonpoint pollution of surface waters with phosphorus and nitrogen. Ecological Applications, 8: 559-568. 
Carlisle DM, Wolock DM, Meador MR. 2010. Alteration of streamflow magnitudes and potential ecological consequences: a multiregional assessment. Frontiers in Ecology and the Environment, 9(5), 264-270.

Cedergreen N, Streibig JC. 2005. The toxicity of herbicides to non-target aquatic plants and algae: assessment of predictive factors and hazard. Pest management science, 61(12), 1152-1160.

Cheviron B, Delmas M, Cerdan O, Mouchel J.-M. 2014. Calculation of river sediment fluxes from uncertain and infrequent measurements. Journal of Hydrology, 508: 364-373.

Chin A. 2006. Urban transformation of river landscapes in a global context. Geomorphology, 79: 460-487.

Clark GM, Mueller DK, Mast MA. 1999. Nutrient concentrations and yields in undeveloped stream basins of the United States. JAWRA, 36(4): 849-860.

Dauer DM, Ranasinghe JA, Weisberg SB. 2000. Relationships between benthic community condition, water quality, sediment quality, nutrient loads, and land use patterns in Chesapeake Bay. Estuaries, 23(1), 80-96.

Dodds WK, Bouska WW, Eitzmann JL, Pilger TJ, Pits KL, Riley AJ, Schloesser JT, Thornbrugh DJ. 2009. Eutrophication of U.S. Freshwaters: Analysis of Potential Economic Damages. Environmental Science \& Technology, 43(1): 12-19.

Dodds, WK, Jones JR, Welch, EB. 1998. Suggested classification of stream trophic state: distributions of temperate stream types by chlorophyll, total nitrogen, and phosphorus. Water Research, 32(5), 1455-1462.

Gassman PW, Reyes MR, Green CH, Arnold JG. 2007. The Soil and Water Assessment Tool: Historical development, applications, and future research directions. Transactions of the ASABE, 50:1211-1250.

Hatt BE, Fletcher TD, Walsh CJ, Taylor SL. 2004. The influence of urban density and drainage infrastructure on the concentrations and loads of pollutants in small streams. Environmental Management, 34:112-124. 
Heimann DC, Sprague LA, Blevins DW. 2011. Trends in Suspended-Sediment Loads and Concentrations in the Mississippi River Basin, 1950-2009. U.S. Geological Survey Scientific Investigations Report, 2011-5200, 33 p.

Howarth RW, Billen G, Swaney D, Townsend A, Jaworski N, Lajtha K, Downing JA, Elmgren R, Caraco T, Jordan T, Berendse F, Freney J, Kudeyarov V, Murdoch P, Zhu ZL. 1996. Regional nitrogen budgets and riverine N \& P fluxes for the drainages to the North Atlantic Ocean: Natural and human influences. Biochemistry, 35(1): 75-139.

Hubbart, J.A., R-M. Muzika, D. Huang, and A. Robinson. 2011. Improving Quantitative Understanding of Bottomland Hardwood Forest Influence on Soil Water Consumption in an Urban Floodplain. The Watershed Science Bulletin, 3:34-43.

Hubbart, J.A. 2011. Urban Floodplain Management: Understanding Consumptive WaterUse Potential in Urban Forested Floodplains. Stormwater, 12(6):56-63.

Kellner, E., and J.A. Hubbart. 2016a. A Comparison of the Spatial Distribution of Vadose Zone Water in Forested and Agricultural Floodplains a Century after Harvest. Science of the Total Environment, DOI: 10.1016/j.scitotenv.2015.10.080

Kellner, E., and J.A. Hubbart. 2016b. Continuous and Event-Based Time Series Analysis of Observed Floodplain Groundwater Flow under Contrasting Land-Use Types. Science of the Total Environment, 566-567:436-445. DOI: 10.1016/j.scitotenv.2016.05.036

Kellner, E., J.A. Hubbart, and A. Ikem. 2016. Corrigendum to: A comparison of forest and agricultural shallow groundwater chemical status a century after land use change. Science of the Total Environment, 529:487. DOI: 10.1016/j.scitotenv.2015.05.052.

Lamba J, Thompson AM, Karthikeyan KG, Fitzpatrick FA. 2015. Sources of fine sediment stored in agricultural lowland streams, Midwest, USA. Geomorphology, 236: 44-53. 
Lerch RN, Kitchen NR, Baffaut C, Vories ED. 2015a. Long-term agroecosystem research in the Central Mississippi River Basin: Goodwater Creek Experimental Watershed and regional nutrient water quality data. Journal of Environmental Quality, 44: 37-43.

Lerch RN, Baffaut C, Kitchen NR, Sadler EJ. 2015b. Long-term agroecosystem research in the Central Mississippi River Basin: Dissolved nitrogen and phosphorus transport in a high-runoff-potential watershed. Journal of Environmental Quality, 44: 44-57.

Letcher RA, Jakeman AJ, Merritt WS, McKee LJ, Eyre BD, Baginska B. 1999. Review of Techniques to Estimate Catchment Exports. Environment Protection Authority, Sydney.

MDNR. 2004. Total Maximum Daily Load for James River Webster, Greene, Christian and Stone Counties, Missouri. Prepared by the Missouri Department of Natural Resources Water Protection Program.

MDNR. 2011. Total Maximum Daily Load for Hinkson Creek Boone County, Missouri. Prepared by the Missouri Department of Natural Resources Water Protection Program.

Meyer WB, Turner BL. 1994. Changes in land use and land cover: a global perspective (Vol. 4). Cambridge University Press.

Meyer JL, Paul MJ, Taulbee WK. 2005. Stream ecosystem function in urbanizing landscapes. Journal of the North American Benthological Society, 24(3), 602-612.

Mohamoud Y, Kraemer S. 2008. Environmental Flow Modeling Challenges for Rapidly Urbanizing Watersheds. SEEFP Conference -Environmental Flows -Water for People and Nature in the Southeast Athens, October, 2008.

Moriasi DN, Arnold JG, Van Liew MW, Bingner RL, Harmel RD, Veith TL. 2007. Model evaluation guidelines for systematic quantification of accuracy in watershed simulations. Transactions of the ASABE, 50(3): 885-900.

Nelson EJ, Booth DB. 2002. Sediment sources in an urbanizing, mixed land-use watershed. Journal of Hydrology, 264(1), 51-68. 
Paul MJ. Meyer JL. 2001. Streams in the urban landscape. Annual Review of Ecology and Systematics, 32:333-365.

Poff NL, Zimmerman JK. 2010. Ecological responses to altered flow regimes: a literature review to inform the science and management of environmental flows.

Freshwater Biology, 55(1), 194-205.

Poff NL, Richter BD, Arthington AH, Bunn SE, Naiman RJ, Kendy E. Henriksen J. 2010. The ecological limits of hydrologic alteration (ELOHA): a new framework for developing regional environmental flow standards. Freshwater Biology, 55(1), $147-170$.

Poor CJ, McDonnell JJ. 2007. The effects of land use on stream nitrate dynamics. Journal of Hydrology, 332(1-2): 54-68.

Preston SD, Alexander RB, Woodside MD, Hamilton PA. 2009. SPARROW MODELING-Enhancing Understanding of the Nation's Water Quality: U.S. Geological Survey Fact Sheet 2009-3019, 6 p.

Quilbe R, Rousseau AN, Duchemin M, Poulin A, Gangbazo G, Villeneuve JP. 2006. Selecting a calculation method to estimate sediment and nutrient loads in streams: application to the Beaurivage River (Quebec, Canada). Journal of Hydrology, 326(1-4): 295-310.

Rabalais NN, Diaz RJ, Levin LA, Turner RE, Gilbert D, Zhang J. 2010. Dynamics and distribution of natural and human-caused hypoxia. Biogeosciences, 7(2), 585-619.

Rabotyagov SS, Klingy CL, Gassmanz PW, Rabalais NN, Turner RE. 2010. The Economics of Dead Zones: Causes, Impacts, Policy Challenges, and a Model of the Gulf of Mexico Hypoxic Zone. Review of Environmental Economics and Policy, 8(1): 58-79.

Roy AH, Freeman MC, Freeman BJ, Wenger SJ, W. E. Ensign WE, Meyer JL. 2005. Investigating hydrological alteration as a mechanism of fish assemblage shifts in urbanizing streams. Journal of the North American Benthological Society, 24:656-678.

Royer TV, David MB, Gentry LE. 2006. Timing of riverine export of nitrate and phosphorus from agricultural watersheds in Illinois: Implications for reducing nutrient loading to the Mississippi River. Environmental Science \& Technology, 40: 4126-4131. 
Sadler JE, Lerch RN, Kitchen NR, Anderson SH, Baffaut C, Sudduth KA, Prato AA, Kremer RJ, Vories ED, Myers DB, Broz R, Miles RJ, Young FJ. 2015. Long-term agroecosystem research in the Central Mississippi River Basin: Introduction, establishment, and overview. Journal of Environmental Quality, 44: 3-12.

Schottler SP, Ulrich J, Belmont P, Moore R, Lauer JW, Engstrom DR, Almendinger JE. 2014. Twentieth century agricultural drainage creates more erosive rivers. Hydrological Processes, 28: 1951-1961.

Sponseller RA, Benfield EF, Valett HM. 2001. Relationships between land use, spatial scale and stream macroinvertebrate communities. Freshwater Biology, 46(10), 1409-1424.

Srinivasan R, Zhang X, Arnold JG. 2010. SWAT ungauged: Hydrological budget and crop yield predictions in the Upper Mississippi River basin. Transactions of the ASABE, 53(5): 1533-1546.

Tong, ST, Chen W. 2002. Modeling the relationship between land use and surface water quality. Journal of environmental management, 66(4), 377-393.

Vogel RM, Fennessey NM. 1994. Flow-duration curves. I: New interpretation and confidence intervals. Journal of Water Resources Planning and Management, 120(4), 485-504.

Walsh CJ, Roy AH, Feminella JW, Cottingham PD, Groffman PM, Morgan II RP. 2005a. The urban stream syndrome: current knowledge and the search for a cure. Journal of the North American Benthological Society, 24(3): 706-723.

Walsh CJ, Fletcher TD, Ladson AR 2005b. Stream restoration in urban catchments through redesigning stormwater systems: looking to the catchment to save the stream. Journal of the North American Benthological Society, 24(3), 690-705.

Wang L, Lyons J, Kanehl P, Bannerman R. 2001. Impacts of urbanization on stream habitat and fish across multiple spatial scales. Environmental Management, 28(2), 255-266. 
Sean Zeiger was raised in Sunrise Beach, Missouri. He graduated from Drury University with a Bachelor of Science during 2011. He matriculated to University of Missouri to pursue a Master's degree in Natural Resources with emphasis in Water Resources during 2011. He obtained his Master's degree during 2014. Then, he entered in to a doctoral program, Natural Resources with emphasis in Water Resources, at University of Missouri. Sean intends to continue working as a research scientist upon completion of his doctoral program. 